$$
\text { en-162 }
$$

\title{
Gas-Cooled Fast Reactor Program Progress Report for January 1, 1974, Through June 30, 1975
}

\section{$A \operatorname{cosics}$}

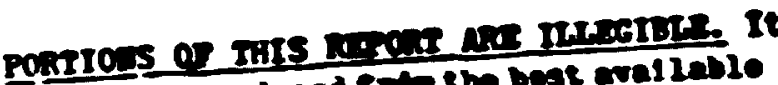
hes boon ropreduced frev tho best eval lable copy to porits us breadast possiblo evallexvils. 


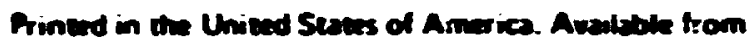
Mations Tecirrical Informotion Service

US. Dperement of Commorte

5265 Port Royal Rand. Springlied. Visinas 22161

Price: Prined Copy S8.00: Microtiche $\$ 2.25$

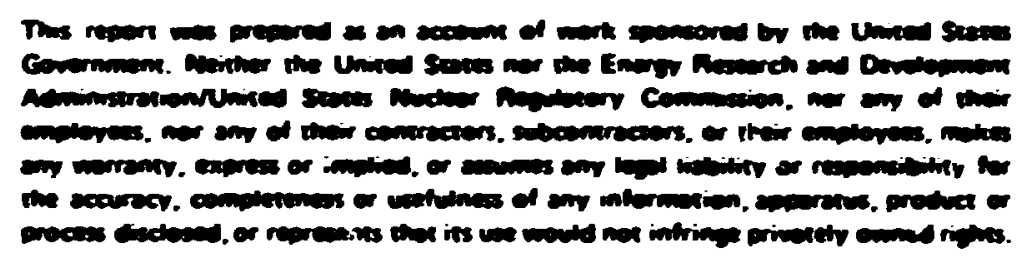


Coatract Do. $1-7405-6 a-26$

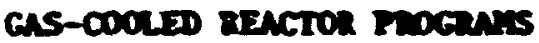

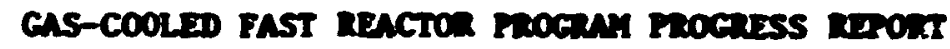

FOR JNDART 1, 1974, THDOJEA JURE 30, 1975

Ori Gat, Progrea Hecuager

Paul R. Resten, Propren DIrector

JUNE $19 \% 6$

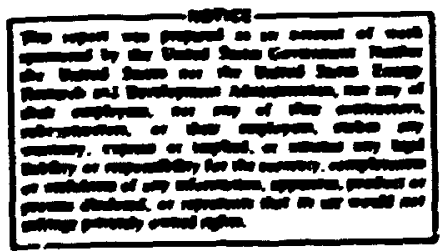

OAR RIDGL RATIOAL LATORATOXY

Oak Ridge, Tempessee 37830

operated by

UNIOU CARBIDE COAPOAATIO

for the

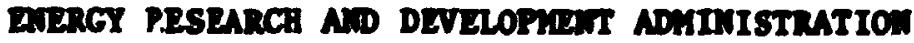




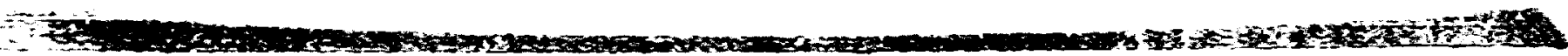

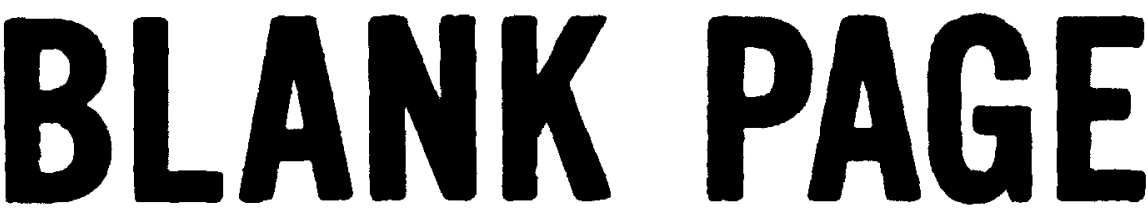


contrirs

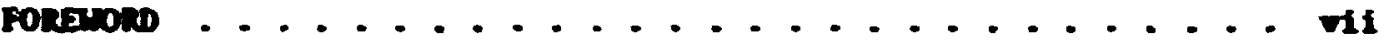

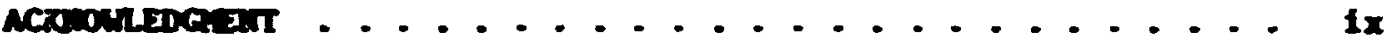

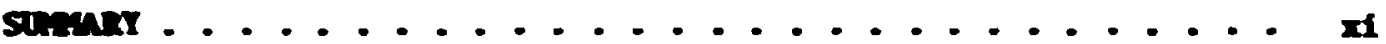

1. cark nessine vessu ad closure sturies .......... 1

1.1 nmodoctias .................. 1

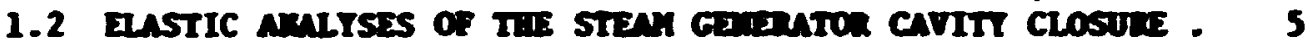

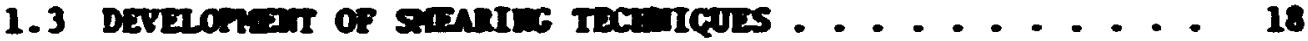

1.3 .1 Hethod 1 ................ 18

1.3.2 Fithod 2 - Goveral Principles ......... 25

1.3.3 Hethod 2 - Procedure ............ 28

1.3.3.1 Application of the Uate Strain

Loeding to the Finite-Elenent Hodel . . 31

1.3.3.2 Calculation of the Strese Components oa the cube in Desponse to Each

Untt Strain Loadins. ......... 33

1.3.3.3 Calculation of Material Constants Meeded for Description of the Sweared Orthotropic Material for Subsequent Axdsymetric Aaslysis ........ 36

1.3.4 Application of Hethod 2 to the Sten Generator Cavity Closure Plus harlyeis ......... 37

1.3.5 Senering: Coaclubioas and Assessmeat ...... 39

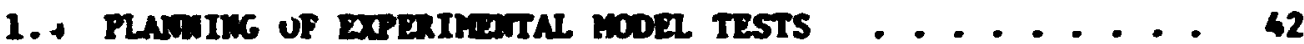

1.4.1 Test Plas ................ 43

1.4.2 Design of the Test Pixture ........... 43

1.4.3 Instrumentation and Fabrication of the Test... 48

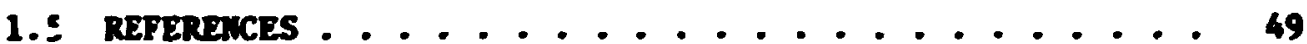

2. CCPR IRRADIATIOA ERPERIMLATS ............. 51

2.1 ImTRODUCTIOA .................. 51

2.2 DESCRIPTION OR CAPSULE GE-10 . . . . . . . . . 53

2.3 IRRADIATION CONDITIONS POR CAPSULE GE-10 . . . . . . 61

2.4 RESULTS FROM IRRADIATION TESTIMG OP CAPSULE GR-10 . . 62

2.4.1 Fuel-Rod Flow Resistance vs Burnup . . . . . 62

2.4.2 Steady-State Fission-Gas Release Rates Versus

Burnup and Operating Pressure . . . . . . . . 64

2.4.3 Stable Moble Gas Release Measuresents at

$13.5 \mathrm{kH} / \mathrm{ft}$. . . . . . . . . . . 70 
2.4.4 Initis Operacion of the G-10 Tritio meltortre syste. . . . . . . . . . . 71

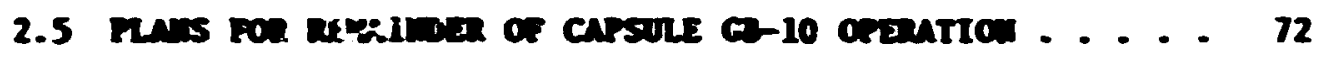

2.6 merdect ................... 73

3. Corr cone nod test loop ................ 75

3.1 Indowction ................. 75

3.1 .1 Objectives .................. 75

3.1 .2 Test cepability .............. 76

3.1 .3 Sumery of Progreas ............... 81

3.1.3.1 Conceptual Desifn .......... 81

3.1.3.2 Doceneatation ........... 81

3.1.3.3 Developeret ............ 81

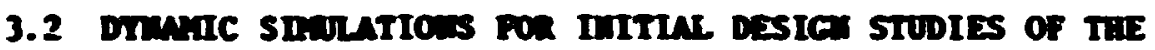

cone Flod TLST LO0P ............... 83

3.2.1 Dacription of halyae ............ 86

3.2.1.1 Far costrol valve studies....... a

3.2.1.2 Depreasurizatioa-Flor studies . . . . 84

3.2.1.3 Tast Section Simlation ....... 87

3.2.1.6 Total Loop Sibulation ........ 89

3.2.1.5 Loop Desiga Trade-off Considerations. . 90

3.2.2 Coaclusions and Recomeadations ........ 92

3.3 Concertun deste . . . . . . . . . . . . 92

3.3.1 loop loyout . . . . . . . . . . . . 92

3.3 .2 Loop Characteristic ............ 95

3.3.3 Loop Arrangement . . . . . . . . . . 96

3.3.4 Loop components and system . . . . . . . . 100

3.3.4.1 Fieat Sinks ............ 100

3.3.4.2 Rellun Purification Syetem . . . . . 101

3.3.4.3 Beliu Supply System . . . . . . . 102

3.3.4.4 Test ressel . . . . . . . . . 102

3.3.4.5 P1ping . . . . . . . . . . 105

3.3.5 Loop Pressure Drop Analyseds . . . . . . . 106

3.4 heliUn cIRcUlators . . . . . . . . . . . . 108

3.4.1 Prelladoaty Inquiry . . . . . . . . . 109

3.4.2 Request for Proposal . . . . . . . . . 113

3.4.3 Proposel Evaluation .............. 114 
3.4.6 Concreccural bepotiations .......... 116

3.4.5 Descriptica of Proposed Circulator Concepts . . 116

3.4.6 Schedale Inprovent . . . . . . . . 117

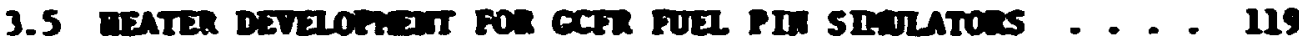

3.5 .1 meacer Desier . . . . . . . . . . 120

3.5 .2 Haterials selection ............. 122

3.5.2.1 Wating Element Baterial ....... 122

3.5.2.2 Beater Leat-In Condectors ...... 125

3.5.2.3 Interndiate haterials . . . . . . 125

3.5.2.4 Eecter Sheach macerial . . . . . . 125

3.5.2.5 Electrical Iewalation ........ 126

3.5.3 Beater Specification . . . . . . . . . 127

3.5.6 Quallty Assurace . . . . . . . . . . 127

3.5.5 Procurement Activities . . . . . . . . 129

3.5.6 Thersocouple Dolse Evaluation ......... 130

3.5.7 Test Section for Beater Test Loop ....... 131

3.6 ELECTRICAL POAL AD COMTOL STSTEA POA CFIL TEST

EUDLE . . . . . . . . . . . . . . 131

3.6.1 Test Budle and Control Criteria ....... 131

3.6.2 Power System . . . . . . . . . . 133

3.6.3 Power Control Criterta ........... 133

3.6.4 Developwent and Testing ............ 134

3.6.4.1 AC Power and Control system ..... 134

3.6.4.2 DC Pover and Control System ...... 141

3.6.4.3 Transfer Punction Test ......... 141

3.6.4.4 Seven-Rod Heater Test ........ 142

3.6.4.5 Bigh Temperature and Pover Test .... 14 b

3.6.4.6 Heater Protection .......... 163

3.7 InSTRURIRTATION AN controls ............. 144

3.7.1 Coolant helfu Flow Measurement........ 145

3.7.2 Heliu flow Control Valves . . . . . . . . 146

3.7.3 Transient controller System ......... 143

3.7.4 High-Speed Data Acquisttion System . . . . . 148

3.7.5 Studies on Insulation Effects in Sma11-Diameter

Thermocouple Material . . . . . . . . 151 
3.7 .6 Tuenocople Dotse in Alternating Hanet le Fiells ................. 161

3.7 .7 Poner smplies for the CIL Test Dadles . . . 164

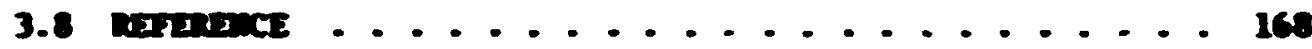

4. Car sirudre stwres ................ 171

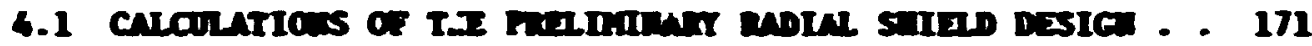

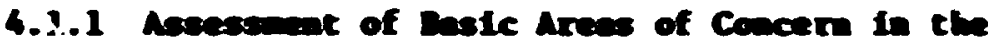
Devioper : of a sideldine Progen for a corr concen mal Deole ............ 171

4.1.2 Troberien of a 51-25 conpled tewron-6om Crovesecten Librat . . . . . . . . . 174

4.1.3 sividing Deviqueat Progra PL . . . . . 176

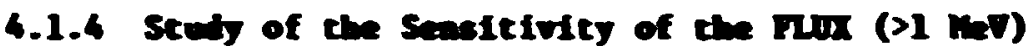
Trenedted to the FCN Linet to Cross Sections In the One Dinastonal Indial Truveres (Core Midplane) Hodel . . . . . . . . . . . 177

4.1.5 Study of Crose-Section, Calculational Parameter, and rodeling Effects on Calculated nesalts for the Inteial Radial shield Configuratioa ..... 180

4.1.6 Comarative Calculation of Daference ad revieed lodels for the outer Radial suteld . . Ies

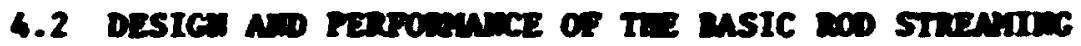
eprennedrs ................ 189

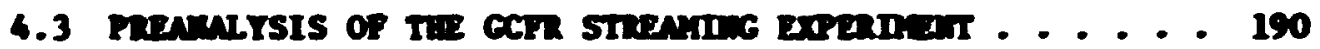
4.3.1 Preanalyols of the stagle-cell streating Experinest . . . . . . . . . . 192 4.3.1.1 nesults ............. 193 4.3.1.2 Contre nates ............ 198 4.3.1.3 Source Wormalization ......... 200 4.3.1.4 Conclustions ........... 200

4.3.2 Premalyeis of the Pull-Arres streadne Experinent .............. 201 4.4 nerendices . . . . . . . . . . . . . . 202

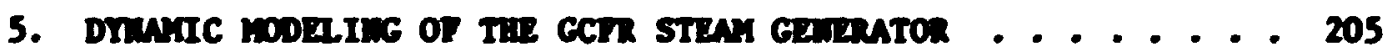


Fondon

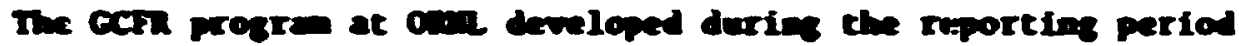

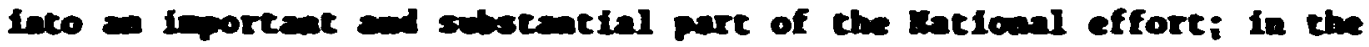

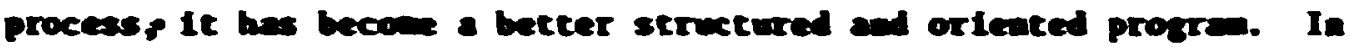

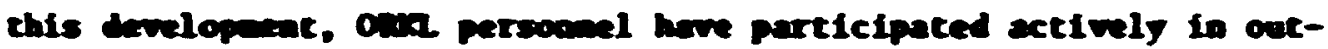

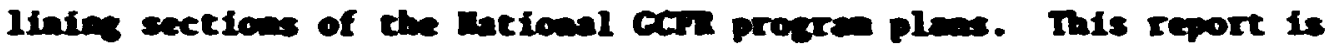
the first separate GCh Progres Deport: previons progress reports

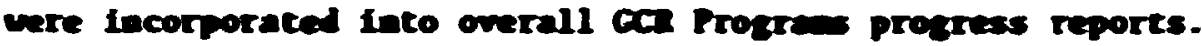

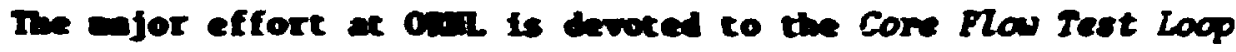

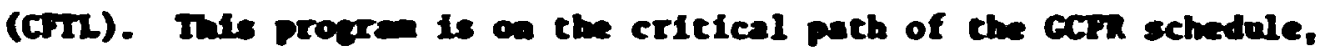

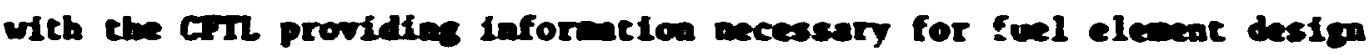

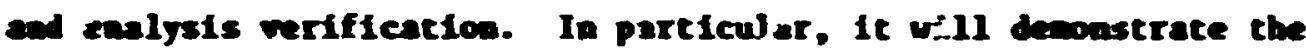

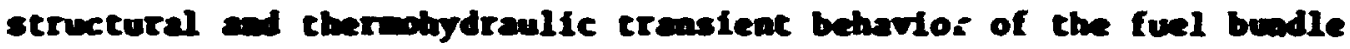
and the rod cledifos, and exll contribute to safety analyse and design inprovenents of future CCris. Thus, the enly copletion of the cest progra is escatial to early avalibbility of the Cas-Coolnd Past Breader, and chis renctor could be an inportant contribution to the ancionel earres suply. The Crt schedule has beafited by Inftation of an circulater purchase late in PI 1975. The heater develophent also progresed in the reporting period. The CIIL test plar wes developed throunh close cooperation with General atode co. (GA). Also, sigificent information related to CMIL needs is derived fros international prostas.

The G-10 Irradiation capsule is an ongoing progran giving Inforation on fission product releave from vanted fuel elenents as well as fuel performance Informetion. Inproved epparatus for on-1ine Ce(Lf) detector analysis wes copleced and used incensively in the report pertod. Gaseous fission product venting and the release fraction deItved from the capsule were utilized in the Mationally used LIPE code. Tritiu antioring equipient was developed and installed in the capeule system. The flow restriction (conductance) mesurements derived from the capeule are uniqu, and the capsule provides a mafor daca source for correlating the performance of CCPR vented and pressure-equalized 
ful (uith roughened cladding) to the performance of Urian fuel. The information derived coetributes to both che CCFR and LuFan prograns.

The FCRV-CLosumes progren concentrates on the experimental and malytical stuly of the closure pluss for PCDr carities. As in any areas of the GCr. strons international thes smooch the flou of infornetion an iprove the overall efficieacy of the progran. Efforts concentrate on the testing of a 1/15-scale model ad plase for a 1/4scale model are beins prepared.

The Shielding wotk enpastzes shieldins and streaning calculations. A beschart streadise experinent at the Tower Shield Facility was perforned ad consticutes a enjor Alestone in the confirnation of calculational methods. The shielding design analysis effort, aleed at optinzation of the shield, san lead to sigaificant cost reductions in the r.x.

The System Response efforts concentrated on axdelfag of the stean generator, and the dymaic response of that component to transients was investigated. Shortage of funds necessitated discontinuacion of this investigation.

All the GCF prograse are closely coordinated with GA and with the Bational and international efforts placed on the CCFR. Further, coordination exists with those parts of the UIPB progran that are related to the CCPR progran. 
ACDOMUDERIS

This report was edited by Sigfred Peterson of the thecals and Ceradcs Division. Tplas and componition were by the Hetals and Cerafics leports Office under the leadership of weredith $R$. Bill. 


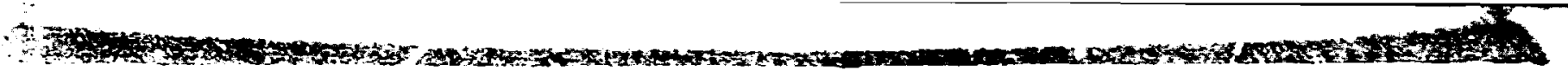

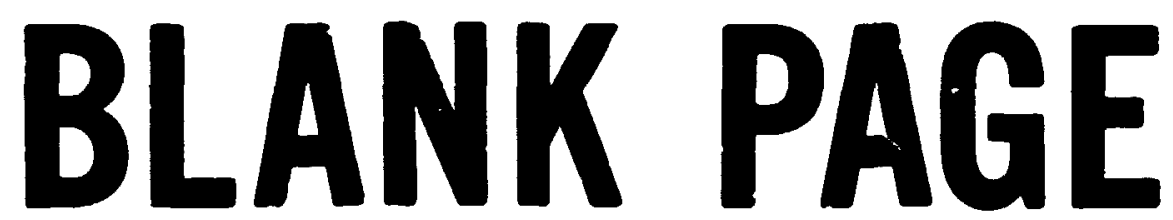

Pun 
SLasuRY

\section{GCFR PRESSURE VESSE AN CLOSURE STUDIES}

Planning for wodel tests of the prestressed concrete reactor vessel closures for the $300 \mathrm{MN}(e) \mathrm{GCFR}$ has been finalized and the plaraing do:unent published. The tests wll be conducted on 1/15-scale and 1/4-scale adels of the sten generator cavity and central core cavity closure pluge. The 1/15-scale wodels will be used for prelininary scoping tests before proceeding with the orre conplez and costly 1/4-scale nodel tests.

Analytical studies of the stean generator cavity ciosure plus have been conducted and the wodel test plan prepared. Elastic axdsymetric analyses have been ade of three candidate plus configurations using two finite element codes, CREEP-PLAST and STATIC SAP. The wethod of analysis is described together with the results of the analyses of the stean generato: cavity closure. A mechanical properties "smearing" technique was used to obtain both satisfactory and econonical adsymetric malyses of nonaxisymetric portions of the stean generator cavity model.

After several conceptual designs of the 1/15-scale stean generator cavity closure wodel were evaluated, the use of a ring of sperical balls In place of the long slender toggle hold-down nemers of the prototype was selected and the proposed test fixture analyzed. Loading tests of Individual steel bearing in spherfcal seats were conducted to verify capability of the bearings to withstand localized stresses well above the code allowable. Detalled drarings of the test fixture and codel have been completed and required raterial procured.

\section{GCFR IRRADIATION EXPERIYLATS}

In the joint ORR-GA-AN Irradiation testing progran for the evaluation of $(\mathrm{U}, \mathrm{Pu}) \mathrm{O}_{\mathrm{r}}$-fueled metal-clad fuel rods for the Gas-Cooled Fast Reactor (GCFR), exphasis continues on the testing of fuel rods of the vented-and-pressure-equalized concept, the reference GCFR fuel rod design. This vented destgn elininates large pressure differentials across the cladding by venting the fuel rod interior to a pressure equalization system. The GCFR fuel-rod testing program benefits from information being developed $f_{1}$ LMBR programs and vice versa, since the fuel and cladding aterials and many of the operating conditions are sinflar for the two reactors.

The current irradiation test, copsule GB-10, and the preceding one, capsule GB-9, were designed to permit an initial evaluation of the overall performance of the vented-and-pressure-equalized fuel rod. Many important aspects of ' GCFR fressure equalization systen are also being 
studied in these tests. Test conditions are typlcal of those expected for a GCFR fuel rod except for the absence of significant fast-neutron exposure.

Postirradiation exanination of the GB-9 fuel rod, which was irradiated at $48.6 \mathrm{kH} / \mathrm{m}(14.8 \mathrm{~kW} / \mathrm{ft})$ peak power level to a fuel burnup of approximately $54 \mathrm{kin} / \mathrm{k} 8$ heavy metal, was completed at ANL and GA during the current report period. The GB-9 experiment, being the first of a kind, yielded a large anount of inforation on the fission :-adduct release and fuel behavior to be expected with the GCFR verited fuel rod.

The GB-10 fuel rod, sinilar to GB-9 but designed with greater capability for measuring fission product release and transport, is being operated in three successive peak power steps: $39.4,44.3$, and $48.6 \mathrm{~kW} / \mathrm{m}(12,13.5$, and $14.8 \mathrm{~kW} / \mathrm{ft})$. Sweep line connections to the GB-10 rod pernit fission product release measurements under a nubber of different sweep flow wodes, including passage of the sweep through the entire rod, simulating a leak in the cladding of a GCFR rod. The matn objective of $\mathrm{CB}-10$ is to obtain detalled information on the release, transport, and trapping of gaseous and volatile fission products. Another objective is to observe the general performance of the rod and to look for any behavior that could be 3 potential proolem for the GCFR. Additional useful information is to be obsained later from postirradiation exdaination of the rod.

The GB-10 measurements and goals were expanded during the current report period. A large effort was devoted to the design and installation of three new systems to increase GB-10 capability for study of fission product release and transport. These were an on-line Ge(Li) gama-ray detector system, which pernits easier and more detalled fission gas release weasurements, a system for taking large gas samples for the deteranation of stable noble gas release rates using mass spectrometry, and a system for measuring tritio release rates. Also, instrumentation is being evaluated and calibrated for future measurements of the $\mathrm{H}_{2}$ and $\mathrm{H}_{2} \mathrm{O}$ impurity levels in the sweep gas.

GB-10 operat ion continued satisfactorily at the intermediate fuelrod power level of $44.3 \mathrm{kH} / \mathrm{m}(13.5 \mathrm{~kW} / \mathrm{ft})$ during the report period. Fuel burnup progressed from 35 to $70 \mathrm{mid} / \mathrm{kg}$. The burnup goal was revised from its original value of 75 to $100 \mathrm{mid} / \mathrm{kg}$.

Fuel-rod flow conductance measurements at $44.3 \mathrm{kH} / \mathrm{m}$ indicate an exponential decline in conductance with increasing burnup. Conductance improves significantly when the power is lowered.

Steady-state release rates for the gama-emitting fission gases were weasured at $44.3 \mathrm{kH} / \mathrm{m}$ under the planned sweep flow modes as a function of time, and as function of operating pressure in a special test. Release data obtained at reduced pressures of 1.48 and $2.17 \mathrm{MPa}$ (200 and $300 \mathrm{psig}$ ) when compared with the release data at the normal 
operating pressure of $7.0 \mathrm{WPa}(1000 \mathrm{psig})$ show the strong suppressing effect of high pressure on the iteady-state venting of gases from the rod. There yas an unexpected effect of heliu pressure on release from the oxide fuel as well as the expected effect on gas-phase transport.

Statle noble gas release rates were measured at $44.3 \mathrm{~kW} / \mathrm{c}$; however, the data revealed a problem in the sapling or analysis techniques. The sapling srsten is currently being oodified in an at tempt to easure representative samples.

The tritiun monitoring systen was operated with calfbration gas in June, 1975. The system is apparentiy operating as designed, promising excellent sensiifity for measuring critiu in the capsule gas.

Plans for the rewainder of the GB-IO irradiation include operation at tine final power level of $48.6 \mathrm{kH} / \mathrm{=}(14.8 \mathrm{kH} / \mathrm{ft})$, tritiu monitoring experiments, and several additional special tests, including pourer cycling near the end of the irradiation.

\section{GCFR CORE FLON TEST LOOP}

The test objectives and requirenents for the GCFR Core Flow Test Loop vere defined. A conceptual design and cost estimace were prepared, and additional cost estimates based on test bundle heater capacity, kind of funding, and construction starting dates were subnitted to ERDA. Appropriate docunentation such as the Conceptual Design Report, Construction Project Data Sieet, Protect Managenent Plan, Quality Assurance Program Index (QAPI), Codes and Standards Proposal, and Sections 1 and 2 of the Syster Design Description was prepared.

Dynamic simulations ade with a computer indicated chat satisfactory loop performance could be achieved with a test loop configuration using two heat exchangers and three fast-acting valves to control coolant helfum flow during transient operation.

Conceptual design layouts were ade of the satisfactory loop configuration ut:lizing existing avallable space in Bullding 9201-3 in the Y-12 Plant. Preparation of prelininary specifications was initiated for heat exchangers, heliu purification, and helium supply. A conceptwal design was ade of the test vessel that houses the test bundles, and a proposai for the codes and standards to be applied to the construction of the CFTL pressure boundaries was prepared. Pressure drops in the conceptual design loop were calculated, including the inlet plenum in the test vessel and the turning of the flow of coolant helium into the test bundle proper. 
$\boldsymbol{x i v}$

After preparation of a tentative specification for a heliu circulator, a prelininary inquiry was ade, by the UCAD Purchasing Division, of the U.S. compressor industry to elicit interest in providing the CrTL circulator equipent. A specification for centrifugal circulators supported on gas-film-lubricated bearings was offered to the three U.S. manufacturers who indicated interest in the prelininary inquiry. After an evaluation tean reviewed the bids and visited the anufacturers, a contract was avarded to Hechanical Technology Inc., Lathan, New York, to produce the circulators.

A speciffcation was prepared for an electric cartridge heater to simulate GCFR fuel pins in CFIL test bundles. A quality assurance plan for the heaters was prepared. Four vendors are making prototypes of the heater. The test section in the existing HIBBR Heater Test Facility was modified to accomodate a single CFI test bundle heater. Low-power heaters were purchased for a seven-heater test to characterize electromagnetic interfereace noise on thermocouples installed inside test bundle heaters.

Plans were ande to evaluate three candidate power supply and control schenes for the test bundle. A test with a bundle of seven low-power heaters was designed to obtain data on the effect of electroagnetic interference associated with each candidate scheme on the temperature signal from thernocouples installed inside heaters. The effects of operation of the heater at design power and tenperature on electronagnetic interference noise will be evaluated in the nodified LhrBR Heater Test Facility vith heater prototypes.

Measurenent and control flow diagrams were made for the conceptual loop design. Work on filters to elidinate or reduce satisfactorily the electronagnetic interference noise on heater thernocouples was initiated after prelininary work Indicated that the existence of noise is probable. A switching systen to add, subtract, or remove individual transforwer windings in a power circuit was devised as one of the three candidate power and control schemes for the test bundle heaters. Work was intelated on the prelininary design of a controller to regulate test bundle power and coolant flow rate and cooling air flow rates to the two heac exchangers during fast transient operation. A preliminary specification for a gas chromatograph to analyze the CFIL heliun was prepared. An ultrasonic device and a combination of venturi tubes and target flowneters are being considered to measure the coolant heliu flow rate to the cest bundle. The insulation resistance of snall-dianeter sheathed thernocouples vas measured under various operating temperature conditions, and the accuracy of the temerature signal from smalldiameter sheathed thernocouples made of Chromel and Alumel was measured against $\mathrm{Pt}-\mathrm{Rh}$ vs $\mathrm{Pt}$ thernocouples at temperatures up to $1000^{\circ} \mathrm{C}$. 


\section{CCFR SHIEDI: STUDIES}

Analytical efforts to date include the ideatification of areas for concern in the GCTR Shielding model supplied by GAC and their incorporation into the GCFR shielding progran plan, the developent of cross-section sets, and their application in parsetric studies to deternine desirable computatioan nodels for GCFR calculations. These cross sections and nodeling approsches were then applied in a crosssection sensitivity study for high-energy flux transalesion to the FCXV 1iner, and to evaluate the effects of proposed revistons to the outer radial shield. The results indicate that the prospects for reduction of the outer radial shield, and therefore the reactor cavity radius, are reasoably favorable fron the shielding point of view.

Eperinental efforts were directed townd a basic rod strening experinent. Experimental configurations were designed for single-cell and mitiple-rod array cylindrical geometries with approxdnately 502 rod fraction by volume. Heasurements for the single-cell pin streadins experinent were completed during June, with the full array experineat scheduled to be corpleted this sumer. Pre-sinilsts of the single-cell experinent showed that significant high-energy neutron streaning should be observed with both $\mathrm{wO}_{2}$ and iron rods. Two-dinensional discrete ordinates calculations were perforned in the adjoint node for a howogeneous full array configuration to provide bias factors for future Honte Carlo calculations of explicit mutiple-pin arrey configuarations.

\section{DYMAMIC MODELIEG OP THE GCFR STEAY GENERATOR}

The final refinements to a dynanic model of the GCFR stean generator were conpleted. 


\section{GCFR PRESSURE VESSEl ad ClOSURE STUDIES}

J. P. Callahen, H. M. Inftemers, and G. C. Robinson

\section{1 nTIODUCTIOn}

As an active participant in the Gas-Cooled Fast Desctor Development Progran, the Oak RAdge lational Laboratory has beew assigned the task of investigating the performace of the closure pluas for both the central reactor cavity and the stean penerator cavities as desigoed by General Atomic Compay (CA).

Figure 1.1 shours a prelininary design of the Prestressed Concrete Reactor Vessel (PCRV) for the 300 iw(e) GCF Dewonstration Power Plant. A dianetral cut has been ade through the cylindrical PCRV, exposing the central reactor core cavity, one of the three stean generator cavities on the right, and one of three audliary cirsulator cavities on the left.

The reactor cavity closure plug can be seen directly above the core. At the upper right, directly above the min hellun circulator, is the stean generator cavity closure plug.

Under normal operation of the plant, the helfue coolant circulates downard through the core, upward around the botton of the core thermal shielding, and out to the stean generator cavity. It then circulates downard through the stean generatsr and back up around the outalde of the stea generator to the an heliun circulators, where it is puped to the top of the core cavity to complete the flow 10op. The closures are designed to resist the nechanical loading of the pressurized coolant.

A prelininary cross section of the reactor cavity plus ts show in 718. 1.2. It will have an erray of extal penetrations for control rod Ineertion. The prinary hold-down sjeten the top of the plus conalsts of a segented wedre and tocele ascembly that transints the forces from the plug at one end to heary forginge anchored by prestressing tendons at the other end. The secondary hold-down eysten constets of steel bayosete protruding from the outer liner of the plus that lock with meching bayonets on the cloure wall of the vessel in the event of prienty syoten fallure. 


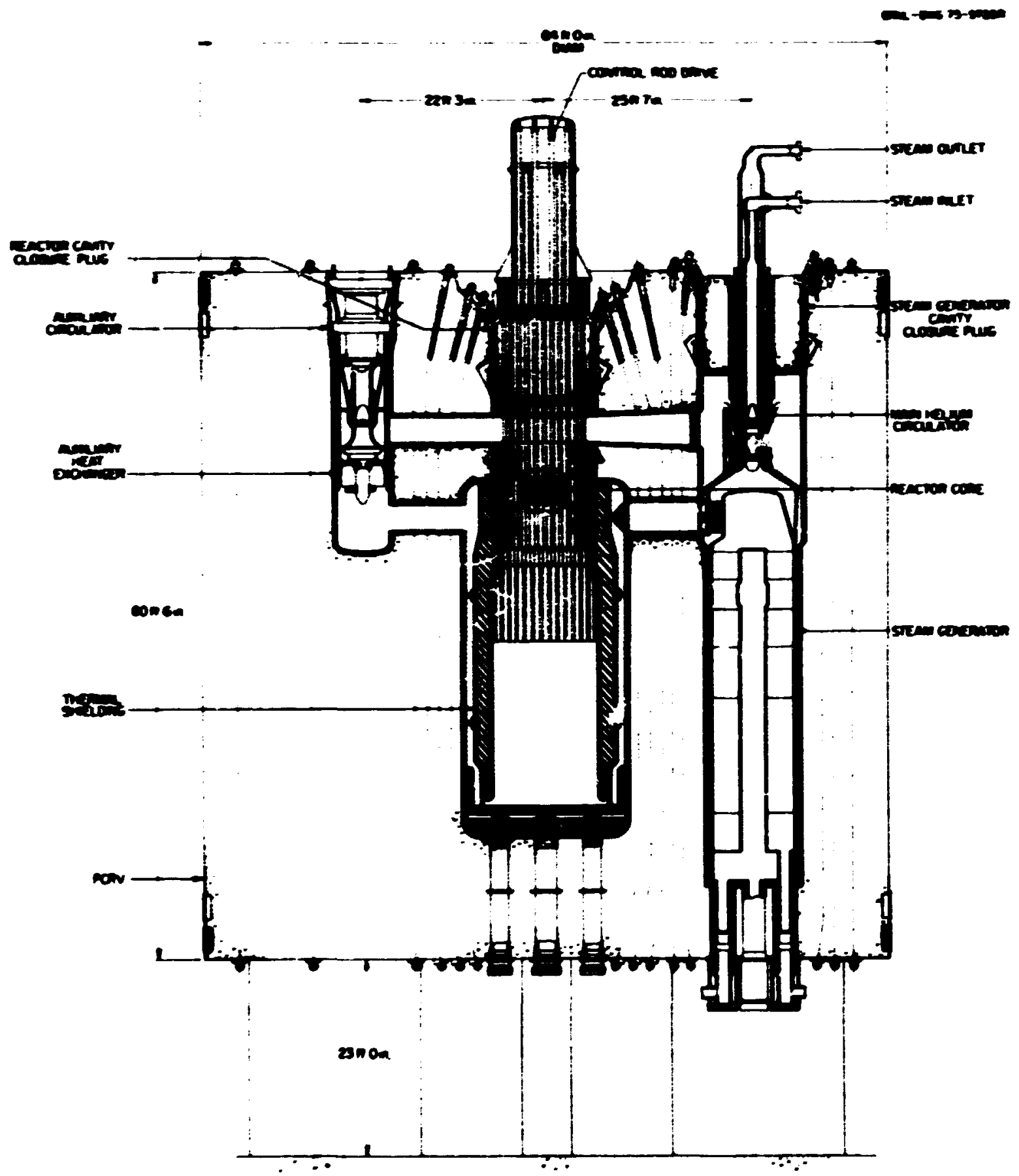

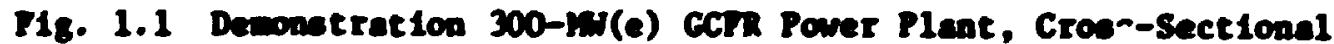

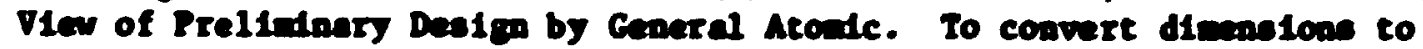
neters, nultiply aubers of feat by 0.305 and inches jy 0.0254 . 


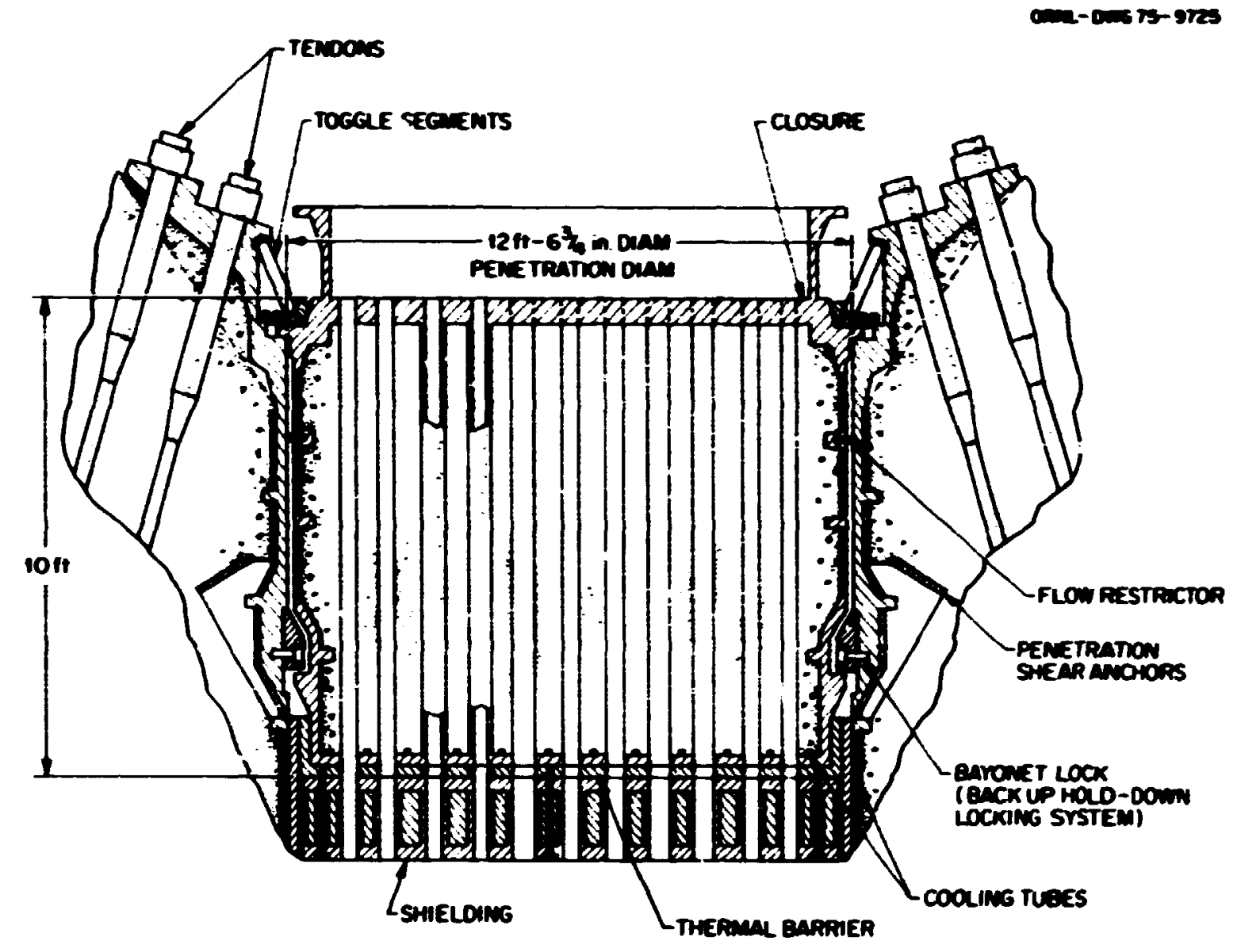

P18. 1.2. Resctor Cervity Closure Plug for CCPR 300-Min(e) Denosatretion Plant Crose-Sectional Pien of Pirst Design Supplied by General Atonc. Penetration diensions are 3.05 by $3.83=$

The heliu seal under nornal operation is at the plug top forging near the primary hold-down systen. The flow restrictor, sindlar to a pleton ring, fits into an Indentation in the plug and cerves to restrict cas flow in the event of fallure of the seal. The same type of holddown aysten and seal are ueed for both closures.

Figure 1.3 shows the Initial design of the sten penerator cavity closure plug as supplied by $C A$. This plug has a central penetration through wich two concentric stean pipes pass. The inaer pipe transporte stean into the vessel to drive the and hellu circulator, and the outer pipe carries stean from the stean ganerator to the power turbines. The win heliun circulator is attached to the botton of the plus. 
OANL- DWO 79-9726

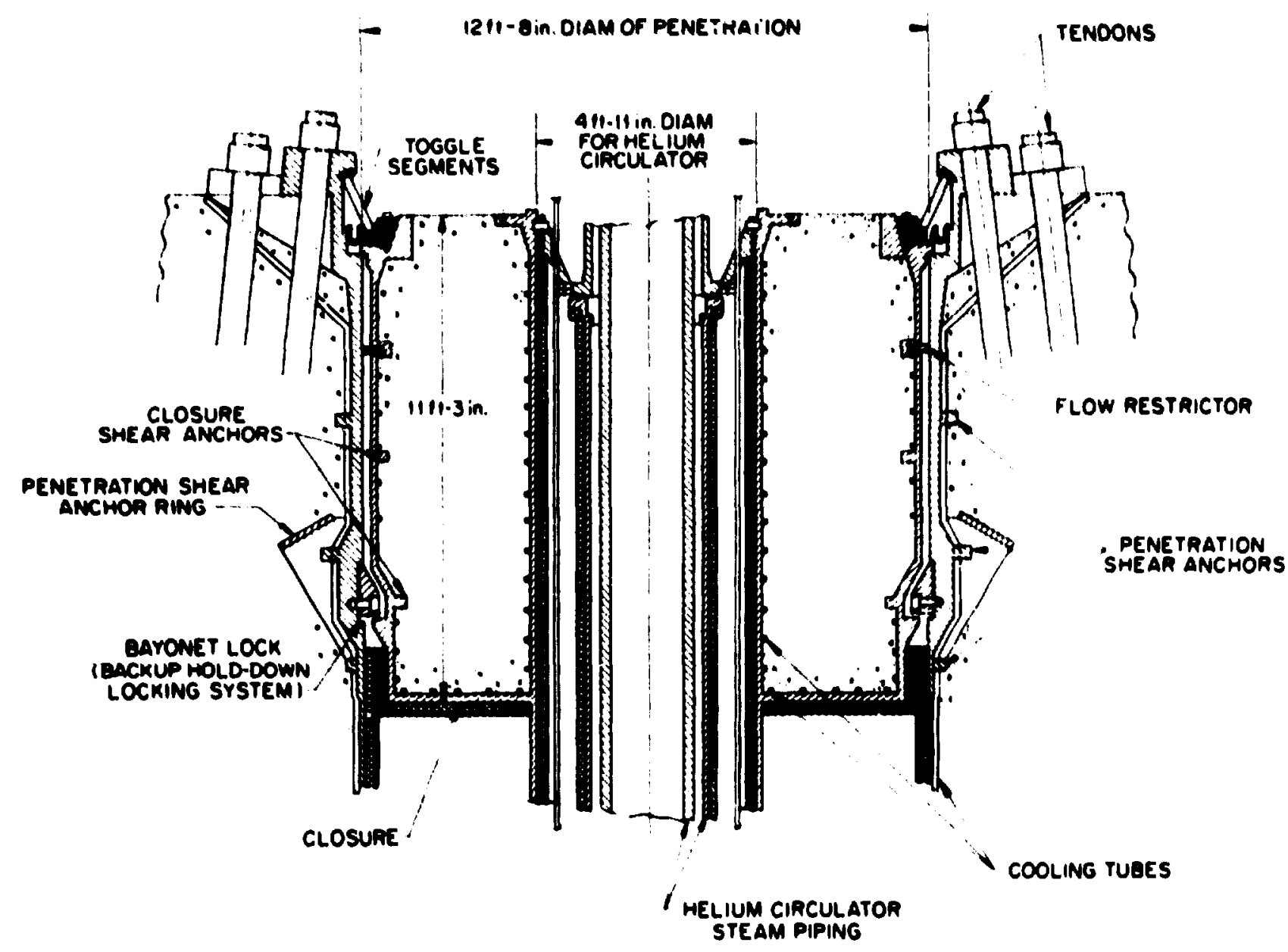

718. 1.3. Stean Generator Cavity Cloaure Plus for 300-rw(e) Damonatration Plant. Crose-aectional view of flrat deaten supplied by Goneral Atonic. Dimenetons ahown are $3.43,3.86$, and $1.42 \mathrm{~m}$. 
The linkage of the piping to the top of the inoer liner of the plus serves only for ailgnent and supports no appreclable load.

A recently prepared pla for conducting the closure wodel tests 11sts these object ives:

1. deternibe the structural response of the closure plugo under desigo operatine conditions, with expasis on ideatifying critical regions of stress concentration;

2. verify the desired gradual structure response to overpreseure;

3. Ideatify crack development and propagation in the concrete during overpressurlzation;

4. deternine ultimate pressure capacity, wde of fallure, and factor of eafety of the closures; and

5. develop and verify theoriea of fallure and analysis methods.

The stean generator carity closure plug was selected for the inftial study primerily because it is sipler than the reactor cavity plug. The stean generator cavity plus has recelved virtually full attention thus far, with the effort being divided between analytical and experinental work.

The plan for the experimental investigation of the stean generator cavity closure is to test a 1/15-scale model of the plug at roon terperature under pressure loading and then a 1/6-scale wodel to allow wore detalled Instrumentation and oodeling of the closure.

The progreas of this past jear is divided into three basic tanks: (1) elastic analyses of the stean generator closure, (2) development of smearing analytical techniques, and (3) planning of experimental model tests. These tasks are discussed individually in detail.

\subsection{EASTIC aUALSES OF THE STEAY gEIERATOR CAVITY CLOSURE.}

Elastic axisymetric snalyses of three designs for the closure plug have been performed by use of the two finite-element codes CRELPPLAST' and STATIC SAP. ${ }^{2}$ The purpose of these analyses initially is to aid in desiging the closure. Once the geometry is selected, elastic calculations are wed to aid in positioning instrumention and designing the 1/15-scale odel experinent. Efforte ere currently under way to 
incorporate a wre opphisticated meterial characterization and perform inelostic salculations of the experimental wodels to secess present anatical cepabllity.

crep-pust is a two-dinenotonal finite-element coste copoble of solving probles with creep and plestefty. Ite elenent itbrary is Iifted to constat-atrain triagles. The code was originaily developed by Y. R. Iaxhid and subequenty odified at Oxil. It has been docuwented and osed exteasively at 0 in and is accompaied by an excellent sraphice progren for output dioploy. Silst odifications vere vecessary to accomodate composite aterial requitements of the closure plugs.

STATIC-SAP, developed at the Daiveraits of Califorail at Berteley, is capoble of hadilag oaly elastc enterial behavior. This code allowe for orthotropy in elastic properties, which is a coavenient feature for the closure analyees. Its extenative elenent library contalns several eleweats for colving three-dinensional problem. The two-dinemolonal elements used are four-node linear isoparanetic quadrilaterals and consent-strain tringles. To gain fadilarity with the we of STATICSAP and confideace in its ability to solve comostite aterials problew. a concrete-steel composite bollow cylinder under interan pressure and plane strain was weled as shown in F1g. 1.4. The calculated streases,.
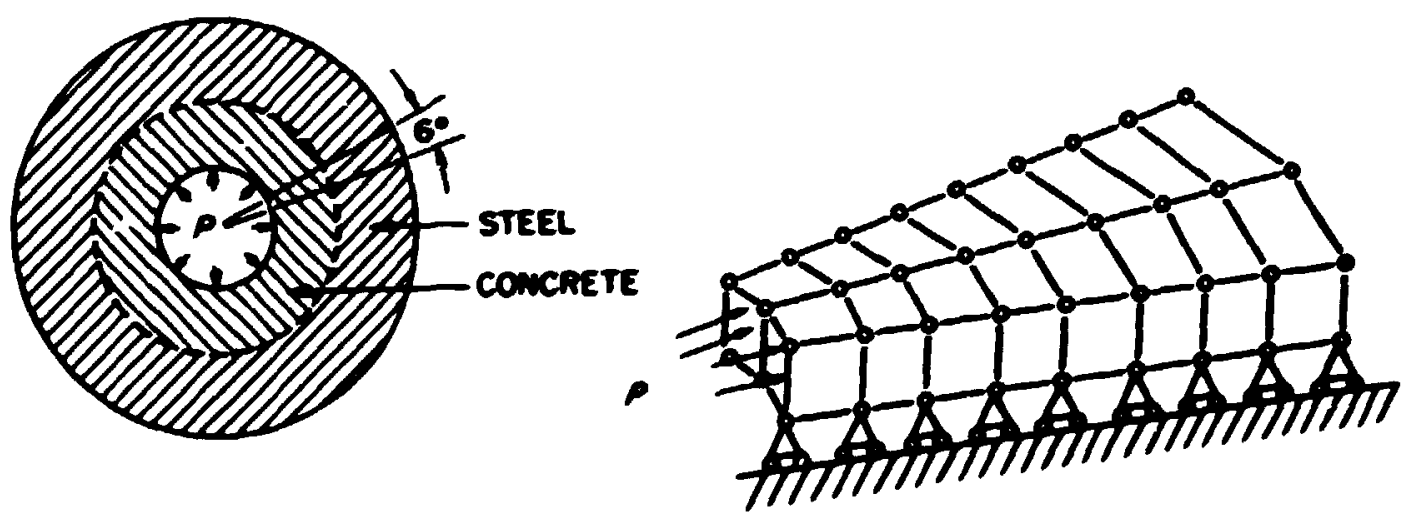

118. 1.4. Composte Cylinder Doder Intermal Preagure and Ple-

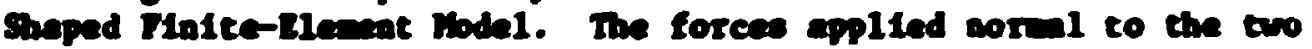

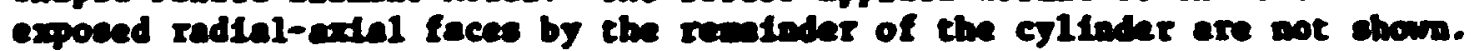


etralos, and dioplaceneats vere is excellent agreenent vith an expet closed-fore solution ad with the results of an earlier axtsymetric analyo ade with Carp-rust.

The first dealon of the plus (Fig. 1.3) was enalyzed vith CuedrTuST for the 10.08 rer (1462 pet) design pressure and the primery bolddow systen in operatioa. Figure 1.5 showe the finite elenent wedh and loading eployed for the analyels. The weth hes 523 constant-otrain trieagle elemeats and 321 mode points. Haterial properties uned for the coactete are Toung's codulus, $E^{f}=41.38 \mathrm{GP}\left(6.0 \times 10^{6} \mathrm{pot}\right)$, and Polseon's ratio, $v^{C}=0.22$; and for the steel, $E^{\circ}=200.0$ GPa $\left(29.0 \times 10^{6}\right.$ pol $)$ and $v^{*}=0.29$. The forces applied to the plus by the beliu circulator are represented by the coscentrated force $P_{c}$ in the laver left corner of the grid. This force to the result of pressure acting upard on the circulator. Internal presaure is applied to the plug at the botton and alons the outer surface (shown on the right side of P18. 1.5). The contect stress $\sigma_{1}$ and $\sigma_{2}$ shown in the upper right corner represent the reactions of the prinery bold-down systen. These stresces are assuned uniforn, and shearing streaces are meglected. The bolt force $P_{B}$, wich restrains the hold-down systee wedges, is deterwined fron force equilibrion of the togele wedge assebly. Rigid body notion has been elinfated by tying down the axdal motion of a node at the upper right corser of the section.

Pigure 1.6 is a contour plot of the largest principal conpreasive streas in the crose-sectional plane of the concrete. The andan calculated concrete stress of approxdmetely $20.7 \mathrm{ma}$ (3000 pal) vas located alowg the outer liner at the flow reatrictor penetration. The aximn calculated steel atress of 124.1 he $(18,000$ par) occurred in the fosgtas directis below the wedge restraining bolt.

A noterorthy result is that the largest value principei strese extbibited slichty tenstle velues at the cop near the laside will. This

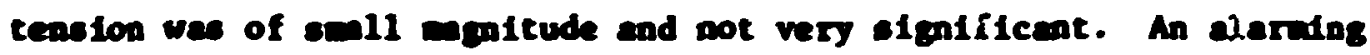
reavit, however, is the appearance of shear streas above $6.9 \mathrm{MPa}$ (1000 pe1) at the concrete-steel 1 iner interface between the flon restrictor and top forgling. The integrits of the bond is doubtful under such high stress. 


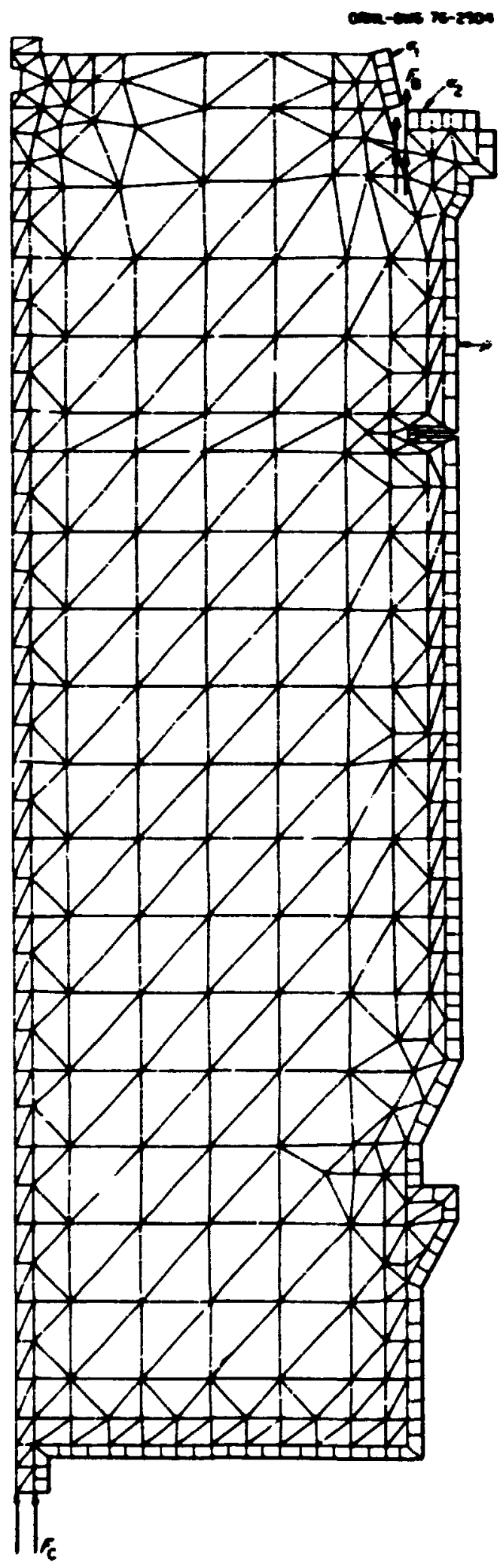

P18. 1.5. Weah Layout and Applied Loedings for CCFR Sten Generator Closure Plug Finfte Elenent Analysis. 


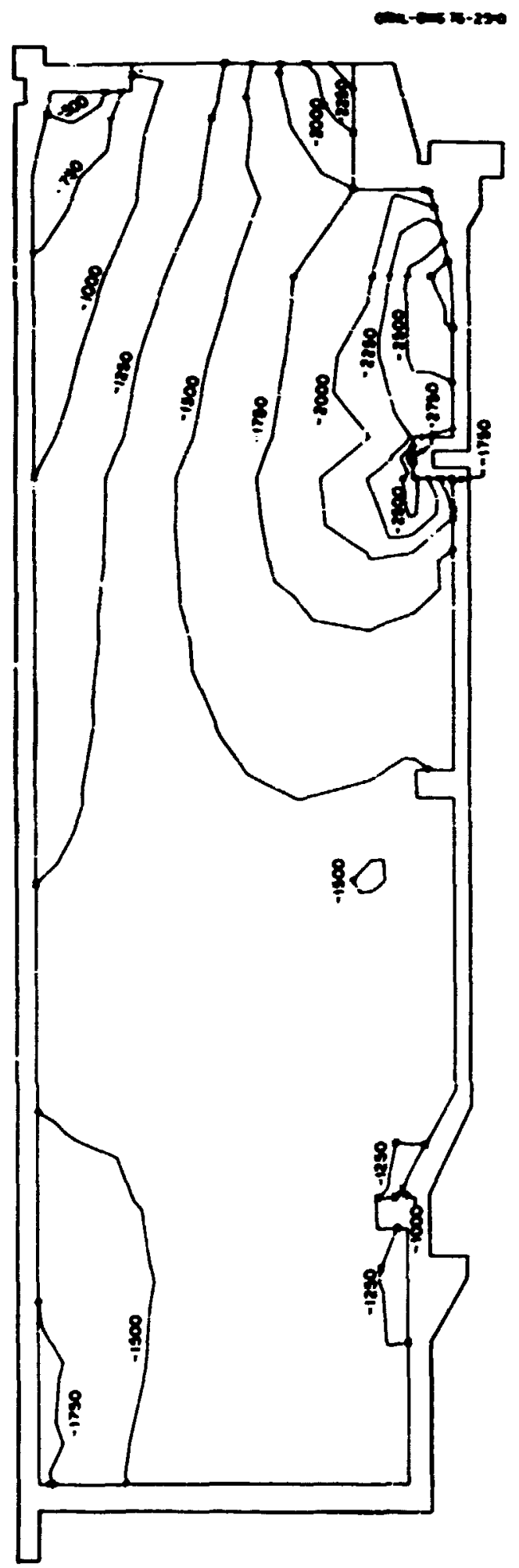

P1g. 1.6. Contour Plot for Maxdeun Culpressive Principal Stress in the Cross-Sectional Plane in the Concrete Produced by $10.08 \mathrm{MPa}$ (1462 psi) Design Pressure. Contours are labeled with compressive stresses in psi; to convert to $\mathrm{MPa}$ multiply by 0.006895 . 
Also, a potcatial beckling teadency upou overprescers ves woted for the fwer limer near the belfo circulator attachnest at the botton of the plug.

PIgure 1.7 show the odified closure design, which Incorporates a "shear console" consiating of a conical steel plate section attuched to the outer liner by a cerfies of steel guset plates and struts. The shent console spsten, which is abedded in the concrete, is designed to reduce shear streas at the Iiner-concrete interface.

Pron the stendpoint of analysis, the shear console syeten Introduces

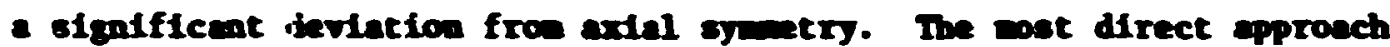
is to perforn a three-dimeasional enaly. 3 of the plus, while taking advantage of the larte degree of adil gymetry of the other parts of the problen. Awother option ts to continu with a axioynetric analysis

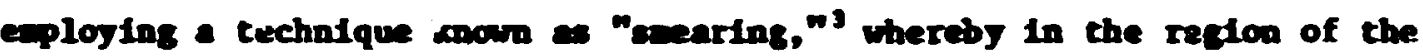
plug spaned by the gasect plate, material properties are averaged in the circunferential direction. A homgeneous elestic orthotropic eterial replaces the steel-concrete composite in this region.

The plan of attack for a three-dimensional analysis would be co odel a ple-shaped segant of the plus bounded by an axdal-radial plane through the center of a guset plate and an axtal-radial pleat through the center of the region Idwey to the adjacent gusset plate. All nodes would lie ou one of several radial-axdal planes, including the two bounding the region. The basic scheme is lllustrated in P1g. 1.8. Although this three-dinensional appraach appears to be stralghforward, restrictions on sopect ratio of elenents require a very dense nesh and therefore an extrenely expensive and tin-consuning analysis.

Por this first phase of the enulyeis in which oodifications of the geometry were anticipated, the smaring approach with a two-dimensioaal axteymetric enalyeis wae chosen. Section 1.3 discusces two methods of searing developed for this application. Doth wethode consiat of replacing the steel-coactate composite reglons of the guset plates and 38.1-n th1ck (1.5-1n.) struts by a single howgeneous but nonisotropic elastic enteriel. 


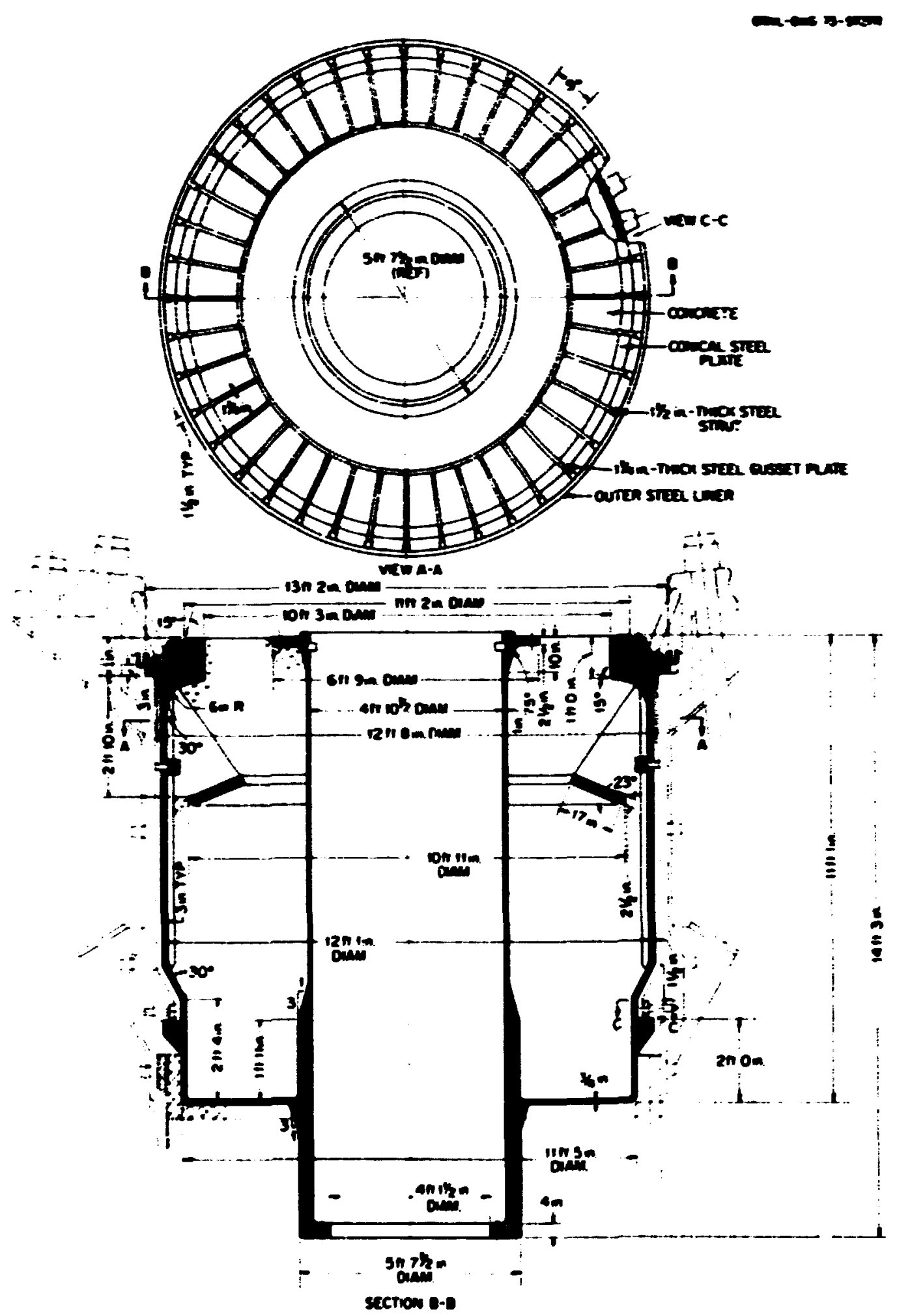

18. 1.7. Revised GCFR Stean Generator Cavity Closure Plug. To convert dieansions to exers, mitiply nubbers of feet by 0.305 and Inches by 0.0254 . 
ORNL-DWG 76-2508

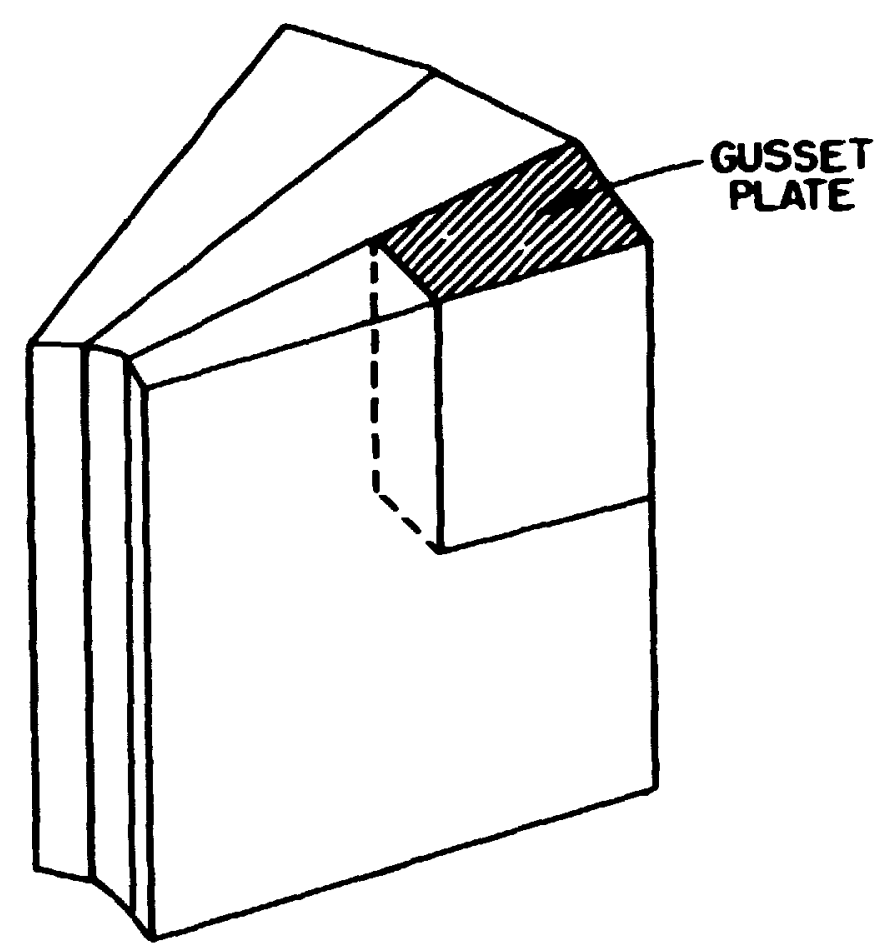

F18. 1.8. Wesh for a Three-Dimensional Analysis.

The code STATIC-SAP has been weed for the analysis of the oodified closure. The finite-element wesh used for the analyols (Fig. 1.9) contains 1181 constant-strain triangle elements and 665 nodes. The 10.08 IPa (1462 pe1) pressure is applied as shown in F18. 1.9 aloas with the corresponding reactions $\sigma_{1}, \sigma_{2}, P_{B}$, and $P_{C^{*}}$ The hold-down system is represented by nornenl contact stresses $\sigma_{1}$ and $\sigma_{2}$, and the axtal bolt force ' $B$ ' is dietributed '..paly between four nodes. The force exerted by the ilrculator, $P_{C}$, 1 asstributed between two nodes.

Four enterials are present in the analytical wodes steel lelastic constants $\left.E^{P}=200.0 \mathrm{GPa}\left(29.0 \times 10^{6} \mathrm{pa1}\right), v^{6}=0.29\right)$, concrete $\left[E^{E}=41.38 \mathrm{GPa}\left(6.0 \times 10^{6} \mathrm{pe1}\right), v^{c}=0.22\right]$, aneared meterial in the region spanned by the gusset plates and a swered aterial in the region spanned by the struts. The first swearing wethod (see lathod 1 of Sect. 1.3) was used to calculate the enterial coastants. The results of 


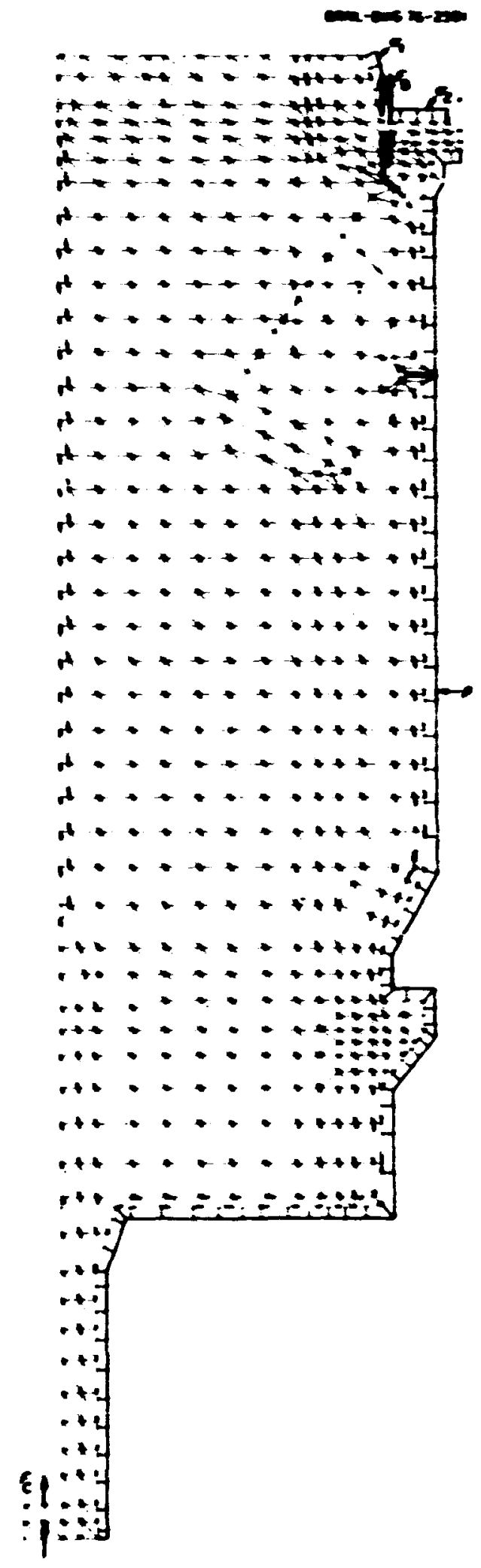

Fig. 1.9. Mech Layout and Applied Loeding for CCP Stea Cenerator Closure Plus FiniteElenent Analysis. 
the ealysts of the ouffied clavere indicated that the ahear console

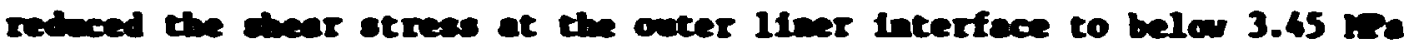
(S00 pal) an strengthened the liner war the circulator atenchent.

$\Delta$ final clowe deate (Fis. 1.10) we provided by CA, primerily to achieve greater eipliefty for the intelal experinental oodels. The odfficetion are a follows:

1. The thick-shell portion of the liner wear the elreulator attachnent hes been rebeed.

2. The secondary bold-dowe systen (bejoset lock) has been rewoved, and the plos geonetry aiplified.

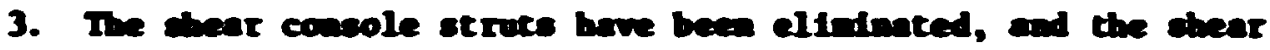
concole is relocated at a laver level in the plus.

4. The flow restrictor indentation has bee elidanted. The flow restrictor renoval is efentficent since the indentation introduced a reglon of streas concentration water the action of the prifing hold-dors syete.

5. In adfitional shear sachor (protrusion of che liner into the concrete) has been alled to the ineer liner.

smared adoymetric elastic andyea hrve been perforned for this desifo, both vith and vithout the flod reatrictor indentation. The

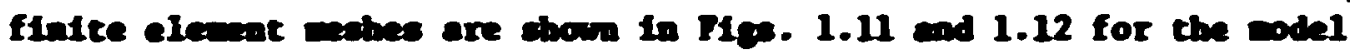
wth and without the flow restrictor indentation, reapectively. The eleneate are motly t-pode limear isoparanetrle quadrilaterals, with several conotent-serata triengles tocloded a needed for tranoition. A preacure loading of 10.08 hea (1662 pat) (design preacure) has been aplied to the botton and outer surfaces of the plug, and a concentrated force representing the action of the bello circulator at this preabure

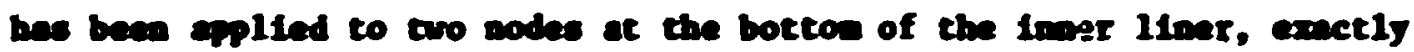

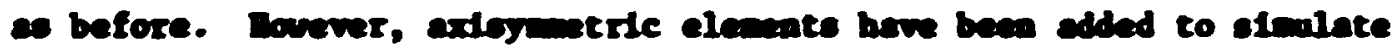

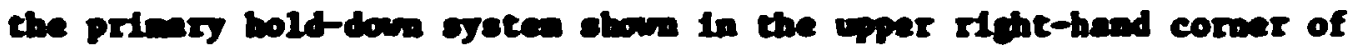

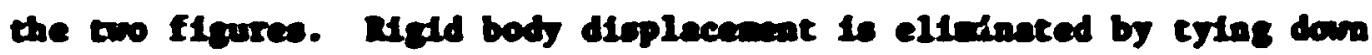
three wodes at the upper richt and of the coscle.

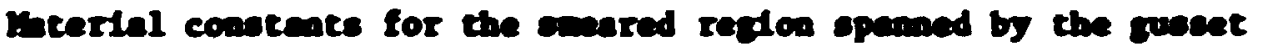

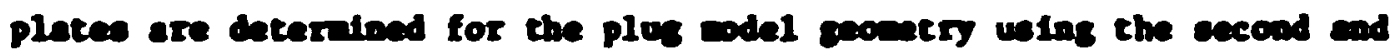




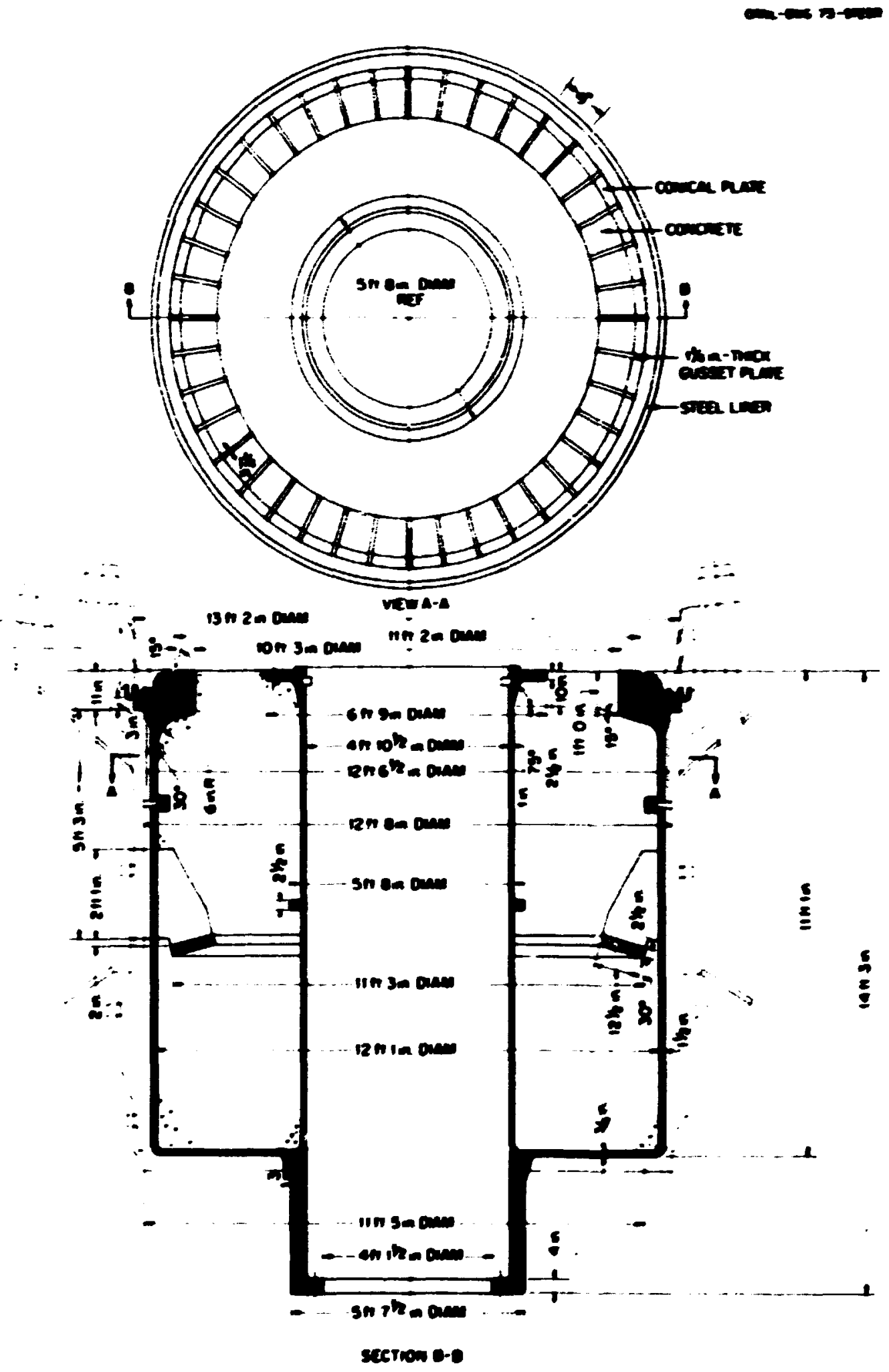

F18. 1.10. CCR stean Gemetor Covity Closure P1ug, Third Dasiga,

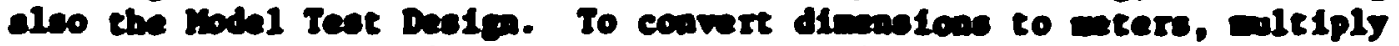
aubere of feet by 0.305 and inches by 0.0254 . 


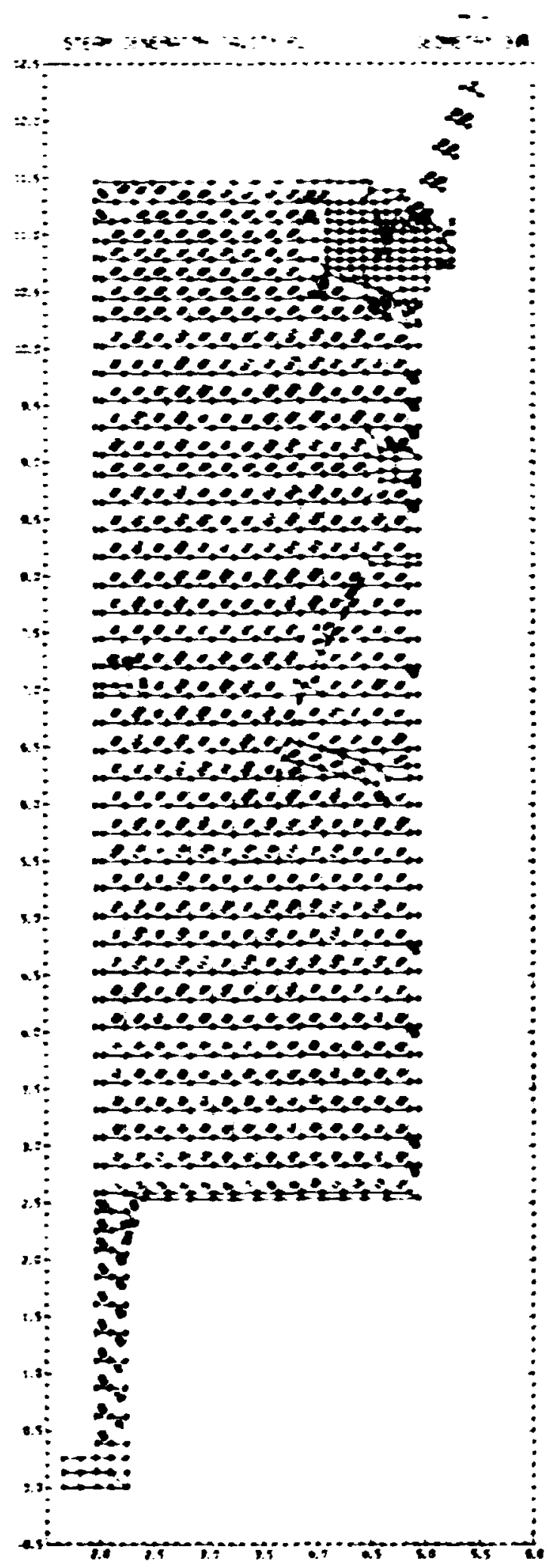

M8. 1.11. Minite-dent num of Can sten Cenerator Covits Clowe Ples (Mird Desige) with Flow deatrictor Indeatakion. 


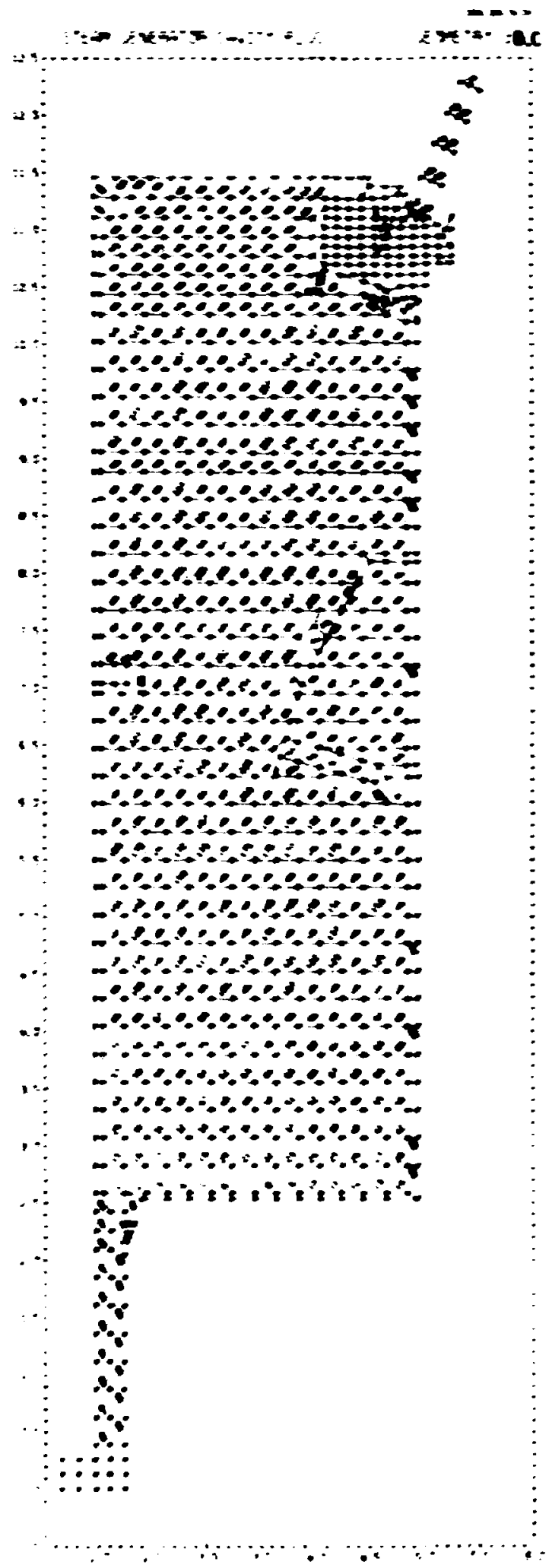

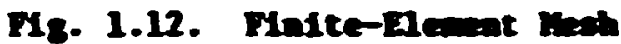
of the GCI Sten Ceneretor Contey Closere Plos (Mind Desige) Without Flou leatrictor. 
iproved searing wethod. (See Bethod 2 of Sect. 1.3.) Grovity bes

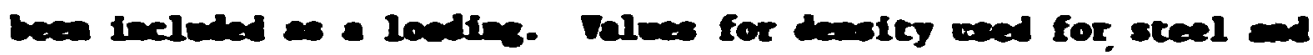

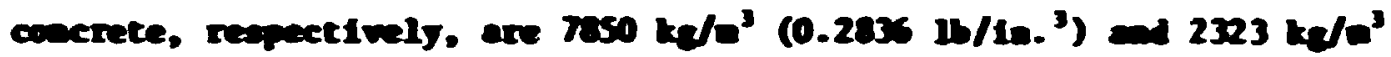

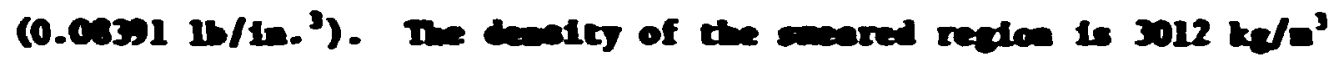

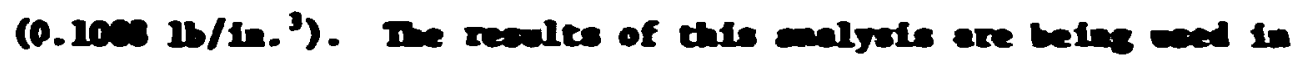

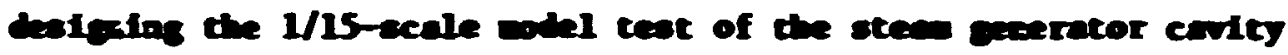
clowere.

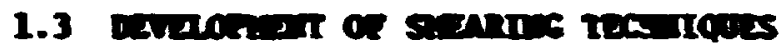

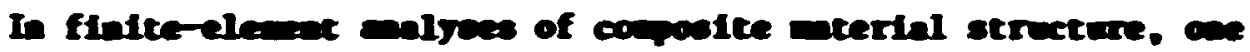

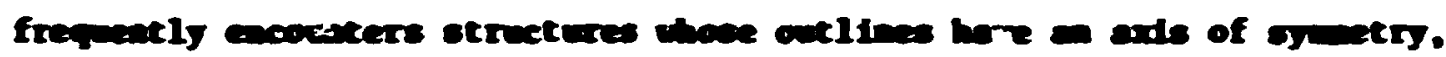

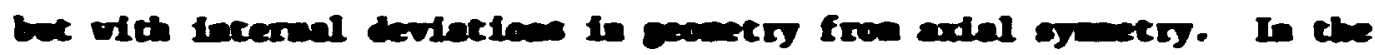

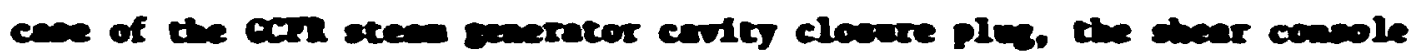

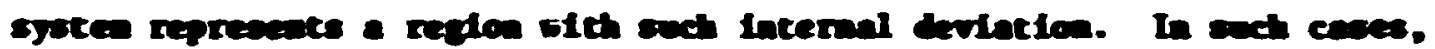
It is often worthbile to exrect informetion from a adoymetric

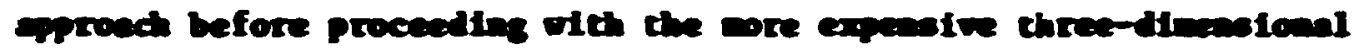

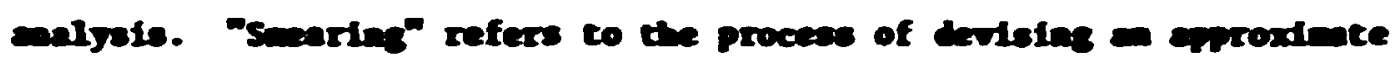
adoymetric woll to a strweture for the purpese.

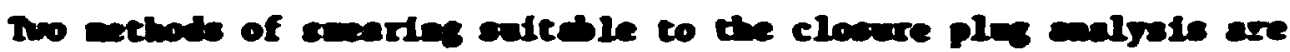

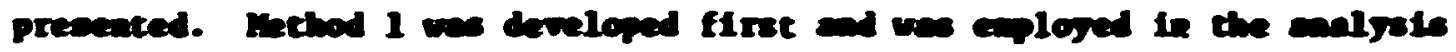

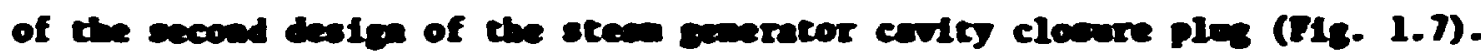
Eathod 2 is sidur be sipificmely refined an wes aplled to the third deate (Mis. 1.10).

\section{3 .1 yand 1}

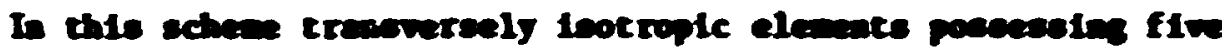

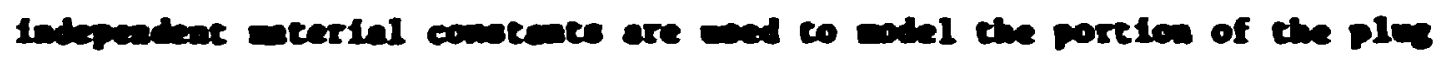

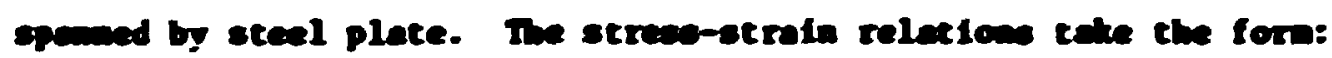

$$
\begin{aligned}
& \varepsilon_{\theta}=\frac{1}{E_{1}} \sigma_{\theta}-\frac{V_{1}}{E_{1}} \sigma_{2}-\frac{V_{1}}{E_{1}} \sigma_{2} . \\
& \varepsilon_{8}=-\frac{V_{1}}{E_{1}} \sigma_{\theta}+\frac{1}{E_{2}} \sigma_{8}-\frac{V_{2}}{E_{2}} \sigma_{5} .
\end{aligned}
$$




$$
\begin{aligned}
& \varepsilon_{p}=-\frac{y_{1}}{E_{1}} \sigma_{\theta}-\frac{y_{2}}{E_{2}} J_{z}+\frac{1}{E_{2}} \sigma_{P} . \\
& V_{r x}=\frac{1}{G_{2}} T_{r a} .
\end{aligned}
$$

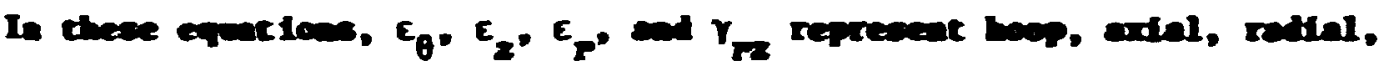

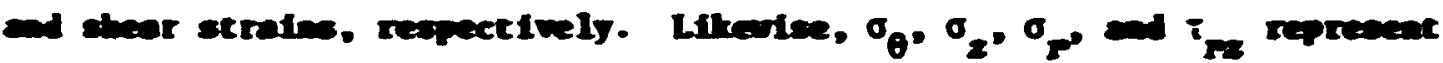

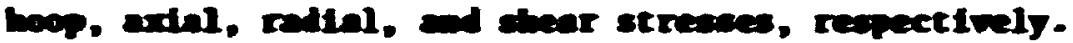

The exertal consents $E_{1}, v_{1}, E_{2}, v_{2}$, and $G_{2}$ charecterise the

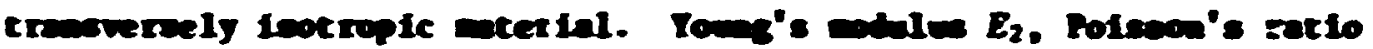

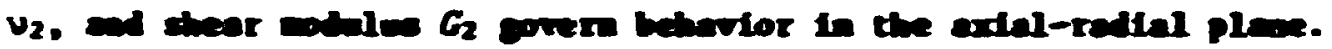

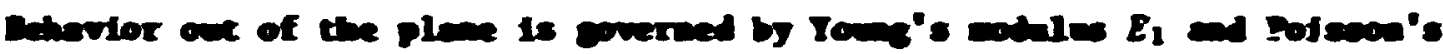

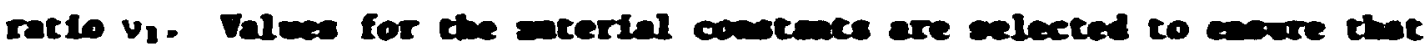

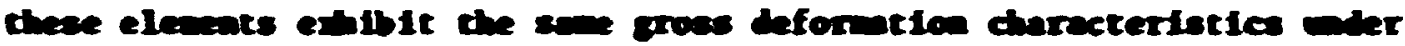

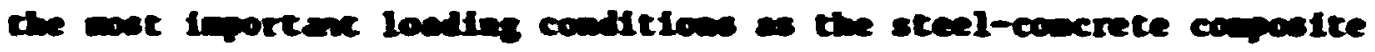
ches represent.

Since the largeat absolute wive strese consonest in this problen Is the hoop streas $\sigma_{\theta}$, che condition of bifore boop stress is comidered Iaitially. A compostce steel (s) coserete (c) paralleleptped is show

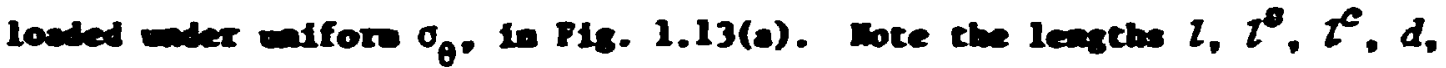
an hefind in this figure. The eterial constats in the steel repion

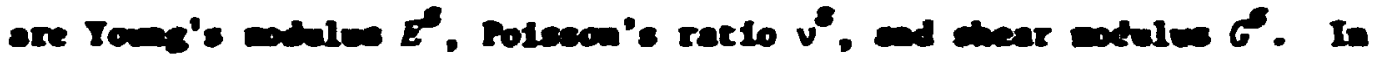

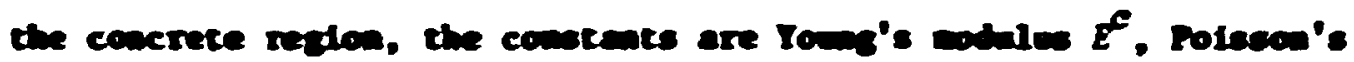

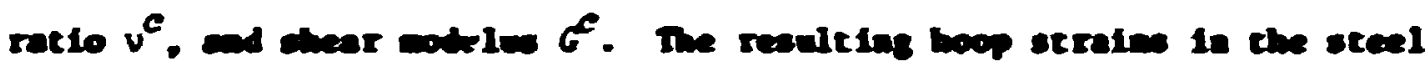
and concrete, reapectively, are

$$
\begin{aligned}
& \varepsilon_{\theta}^{*}=\sigma_{\theta} / E^{0} . \\
& \varepsilon_{\theta}^{c}=J_{\theta} / E^{e} .
\end{aligned}
$$

The corresponding elongetion in sceel ad conctete, respectively, are

$$
\delta_{\theta}^{*}=\tau_{\varepsilon}^{*}=\frac{\tau^{*}}{E} \sigma_{\theta}
$$


$002-0006 \pi-2502$

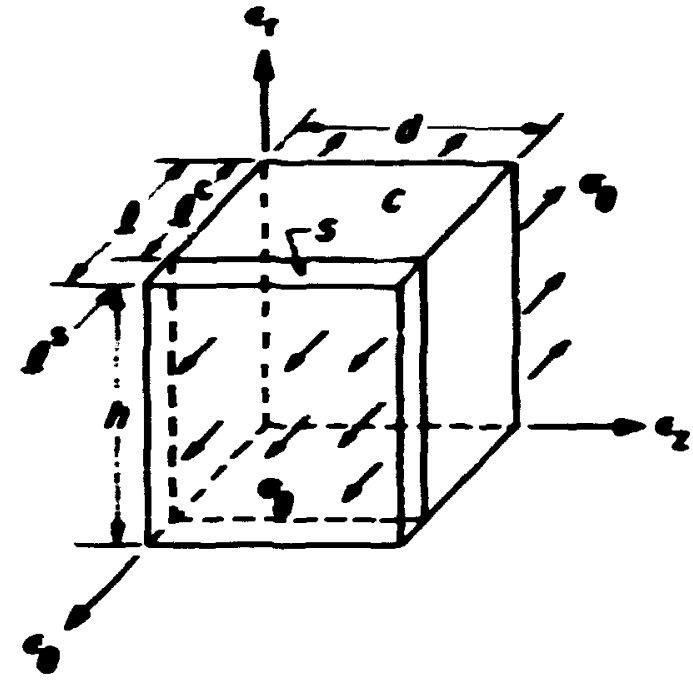

(a)

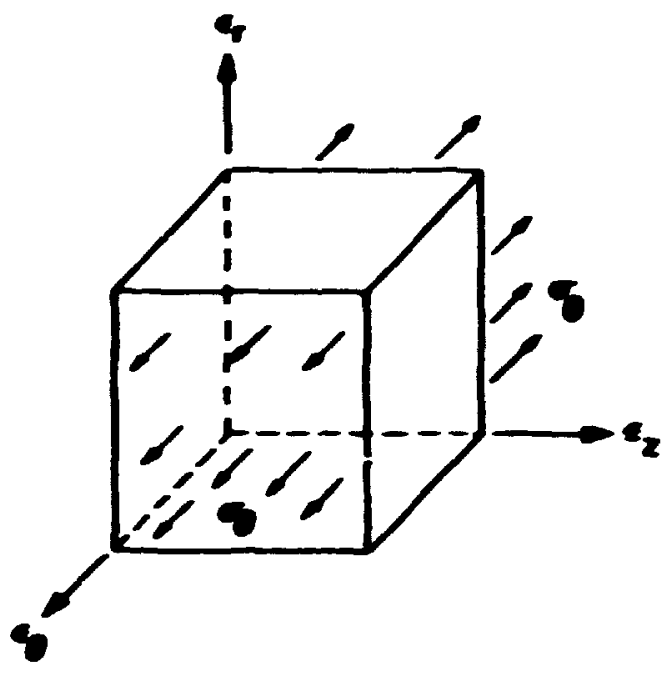

(b)

F18. 1.13. Parrelelepipale vith Intfore $0_{\theta^{\circ}}$ (a) Composice. (b) Tranoversely isotrople.

$$
\delta_{\theta}^{c}=\tau^{c} \varepsilon_{\theta}^{c}=\frac{\tau^{c}}{E} \sigma_{\theta} .
$$

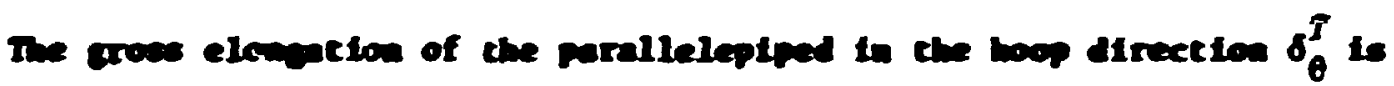
then

$$
\delta_{\theta}^{z}-\delta_{\theta}^{\infty}+\delta_{e}^{c}-\left(\frac{L^{\infty}}{E}+\frac{\tau^{c}}{g^{2}}\right) \sigma_{\theta}
$$

Define the effect ite boop serale by

$$
c_{\theta}^{*}=8_{\theta}^{2} / 2
$$

Subericueing Eq. (6) inco (5),

$$
c_{\theta}^{*}=\left(\frac{E}{E}+\frac{c}{E}\right) \sigma_{\theta}-\left(\frac{E^{c} c^{2}+E^{2} t}{E E^{2}}\right) \sigma_{\theta} .
$$


were $f$ and are defined by

$$
\begin{aligned}
& f=\tau^{2} / 2 . \\
& f=z^{c} / 2 .
\end{aligned}
$$

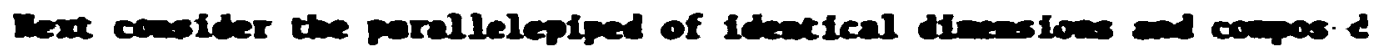
of traversels isotrople eterial (TM.), cescribed by Eqs. (1). This

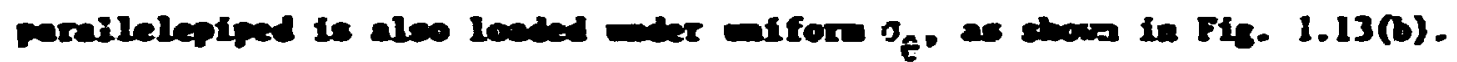
Fros Eq. (10) its realting bop strat is

$$
\varepsilon_{e}=\frac{1}{E_{1}} \sigma_{0}
$$

Compring Egs. (G) (e), for

$$
E_{1}=\frac{E^{2} E^{C}}{j E^{2}+J^{2} E^{3}}
$$

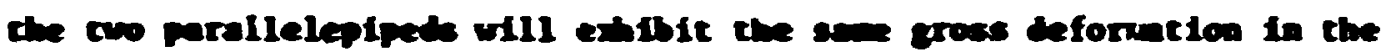

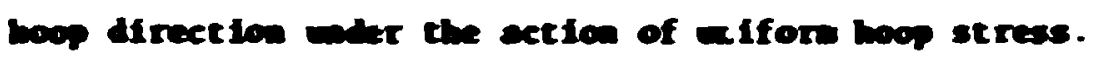

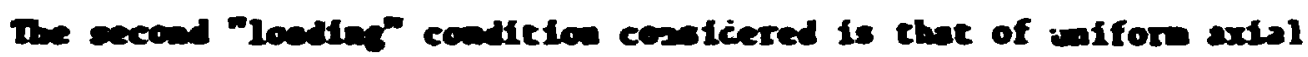
clonpetion of with wo deformation allared in the bep or redial directions. As show in Fis. 1.16(a), the adal strein in both the steel and concrete portions of the parallelepiped, $c_{z}^{*}$ and $\varepsilon_{z}^{c}$, respectively, are given by

$$
\varepsilon_{2}^{c}=\varepsilon_{2}^{c}-s_{z} / d \equiv \varepsilon_{2}
$$

The reaulting axdal streaces in these steel ad concrete reglons are

$$
\begin{aligned}
& \sigma_{2}^{c}=E^{\infty} \varepsilon_{2} . \\
& \sigma_{2}^{c}=E_{\varepsilon_{2}} .
\end{aligned}
$$

The cot.11 axial reaction force $\left(F_{x}\right)$ permerated is then

$$
F_{2}=\sigma_{2}^{*} z_{h}+\sigma_{z}^{c} c_{h}
$$


ORNL-DWG 76-2503

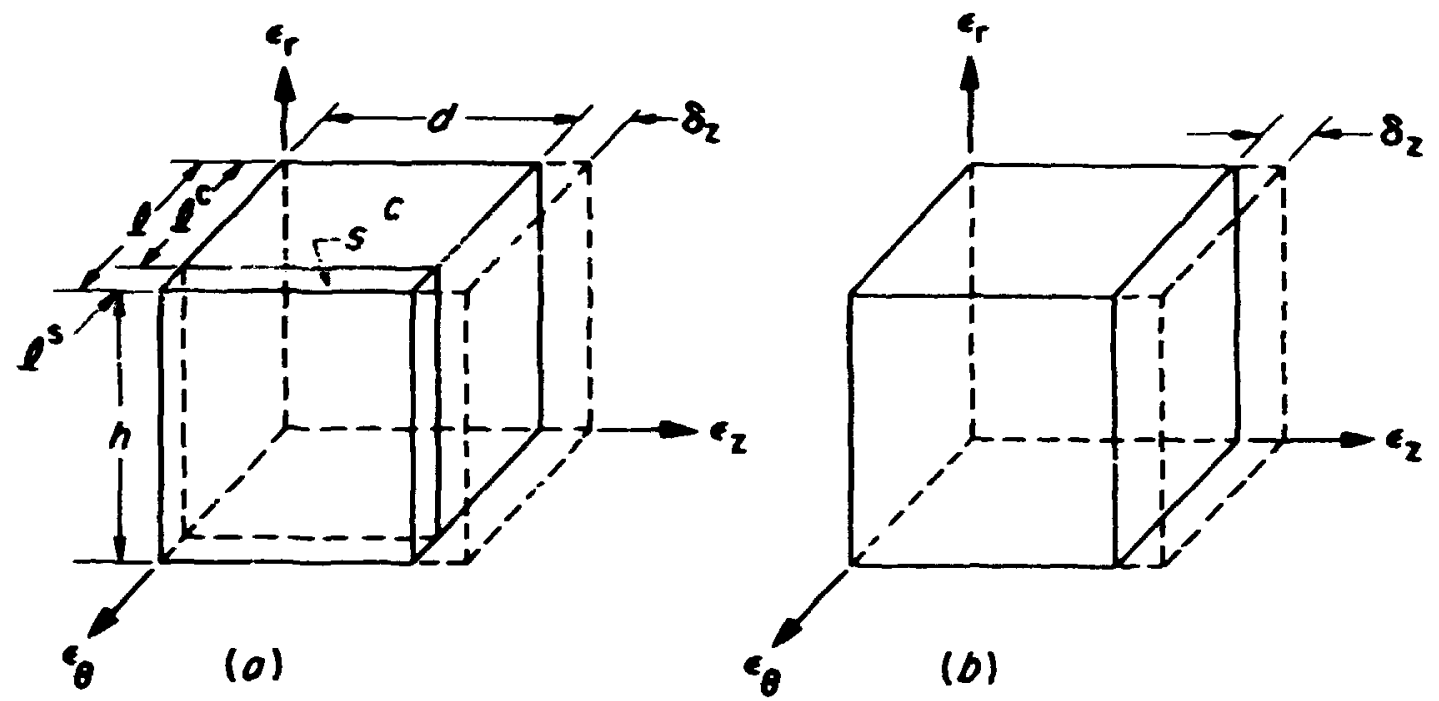

Fig. 1.14. Parallelepipeds with Uniform Axial Elongations, $\delta_{z}$.

(a) Composite. (b) Transversely Isotropic.

Using Eqs. (7a), ( (b), (11a), and (11b) in Eq. (12) gives

$$
F_{z}=\left(f^{\beta} E^{B}+f^{c} E^{c}\right) Z h \varepsilon_{z}
$$

Define the effective axial stress by

$$
\sigma_{z}^{\star}=F_{z} / \text { Ih }=\left(f^{\beta} E^{B}+f^{\left.\mathcal{E} E^{\mathcal{E}}\right) \varepsilon_{z}}\right.
$$

For the transversely lsotropic paraljelepiped under the same "loading," as show in Fig. 1.14 (b), Eqs. (1) show the axial stress to be

$$
\sigma_{z}=E_{2} \varepsilon_{z} \text {. }
$$

Comparing Eqs. (14) and (15), for

$$
E_{2}=f^{\beta} E^{\beta}+f^{\mathcal{C}} E^{\mathcal{C}}
$$


the two parallelepipeds will generate equivalent axial stresses in response to unifor axial strains. Hote that if uniform radial strain were imposed, the same expression for $E_{2}$ [Eq. (16)] would result.

The third condition imposed is unifore shear strain $Y_{\mathrm{Fz}^{*}}$. The composite parallelepiped "loaded" under $Y_{p z}$ is shown in Fig-1.15(a). The shear strain in both the steel and concrete sections is

$$
r_{r 2}^{s}=r_{r 2}^{c}=r_{r z}
$$

where $\gamma_{r Z}^{s}$ and $Y_{I Z}^{c}$ are shear strains in the steel and concrete, respectively. The resulting shear stresses are

$$
\begin{aligned}
& \tau_{r Z}^{s}=G^{s} Y_{r Z}^{s}=G^{s} Y_{r z}, \\
& \tau_{r Z}^{c}=G_{Y Z}^{c}=G^{c} Y_{r Z} .
\end{aligned}
$$

ORNL-OWG 76-2505
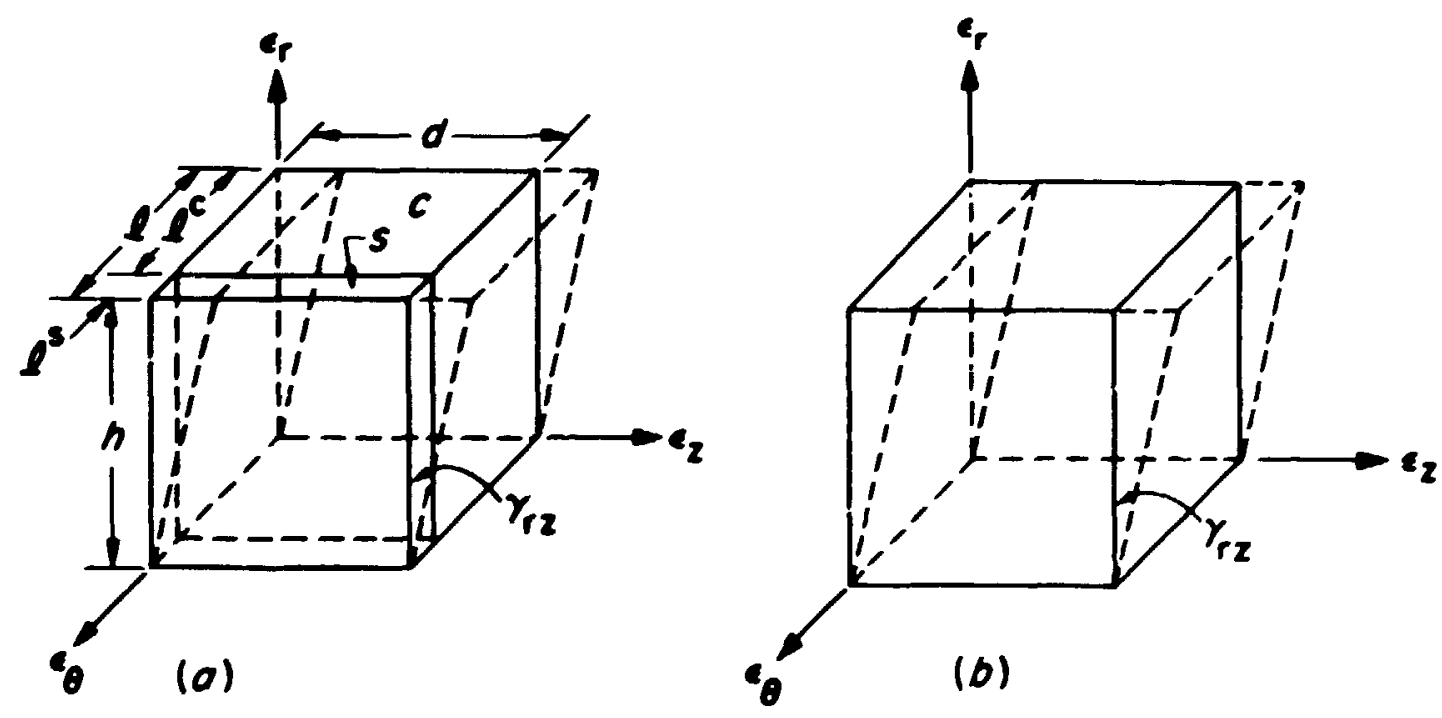

Fig. 1.15. Paralleleptpeds with Untf rm Shear Stroin $Y_{p 2^{*}}$ (a) Composite. (b) Transvergely isotropic. 
The total shear force $F_{p z}$ generated by the parallelepiped as a reaction is

$$
F_{1 z z}=\tau_{r z}^{s} l^{s} d+\tau_{p z}^{c} l^{c} d
$$

Substituting Eqs. (7a), ( $(b),(18 a)$, and (18b) into Eq. (19) gives

$$
F_{12}=\left(f^{3} G^{s}+f^{c} c^{c}\right) l_{\gamma_{Y 2}}
$$

The effective shear stress $\tau_{r z}^{*}$ is defined by

$$
\tau_{r z}^{\star}=\frac{F_{y z}}{l d}=\left(f^{8} G^{s}+f^{c} G^{c}\right) \gamma_{r z}=\left[\frac{f^{8} E^{8}}{2\left(1+v^{8}\right)}+\frac{f^{c} E^{c}}{2\left(1+v^{c}\right)}\right] \gamma_{r z}
$$

For the transversely isotropic parallelepiped shown in Fig. 1.15(b) the shear stress in response to the uniform $Y_{p z}$ imposed 1s, by Eq. (1d),

$$
\tau_{\mathbf{r z}}=G_{2} \gamma_{\mathbf{r z}}
$$

Comparing Eqs. (21) and (22),

$$
G_{2}=\frac{f^{B} E^{B}}{2\left(1+v^{B}\right)}+\frac{f^{\mathcal{C} E^{\mathcal{C}}}}{2\left(1+v^{\mathcal{C}}\right)}
$$

guarantees the proper response.

To complete the scheme, simply use the Poisson's ratio of concrete; namely,

$$
v_{1}=v_{2}=v^{c}
$$

Equations (9), (16), (23), and (24) constitute the smearing scheme that was used in analyzing the second geometry of the plug. The equations were applied to both the 32-mm-thick (1 1/4-in.) gusset plate region and the 38-whick ( $\left.1 / 2-1 n_{\text {. }}\right)$ strut region. The values used for the Poisson's ratios are $v_{1}=v_{2}=0.22$. The elastic moduli obtained are in Table 1.1. 
Table 1.1. Elastic Hodull Obcained by Method 1 Swearing

\begin{tabular}{llclll}
\hline \multirow{2}{*}{ Hodulus } & \multicolumn{2}{c}{$\begin{array}{c}\text { Value for Gusset } \\
\text { Plate Region }\end{array}$} & & \multicolumn{2}{c}{$\begin{array}{c}\text { Value for Strut } \\
\text { Region }\end{array}$} \\
\cline { 2 - 3 } \cline { 5 - 6 } & $(G P a)$ & (psi) & & $(G P 2)$ & (psi) \\
\hline$E_{1}$ & 61.175 & $8.8704 \times 10^{6}$ & 62.058 & $8.9984 \times 10^{6}$ \\
$E_{2}$ & 45.925 & 6.6591 & & 46.151 & 6.6919 \\
$\sigma_{2}$ & 24.517 & 3.5549 & & 24.854 & 3.6038 \\
\hline
\end{tabular}

\subsubsection{Yethod 2 - General Principles}

This second whod represents a refinement to the first. A wre wethodical wethod for applying load cases to the finite element wodel has been incorporated. The sweared region is represented as an orthotropic elastic mterial described by seven independent mterial constants, as opposed to the sipler transversely isotropic representation of Hethod 1 having only five independent constants. The method will be described first in generality, and later applied to the closure plug study.

A general procedure for smearing in finite element structural analysis will be presented here. It is valid for structures with two necessary geometric properties; (1) the outline of the structure must be axisymetric, and (2) in the region or regions of the structure in which deviations from axial symetry exist, the geometry mist vary circumfesentially abour the axis of symetry of the outline with a rapid periodicity.

Figure 1.16 shows a simple structure that satisfies these requirements. A cylindrical $r-\theta-2$ coordinate system is implied in the figure, with the $z$ axis being the axis of symetry of the structure's outine. Area $S$ is the projection of the region in which geometry varies circurferentially. The condition of rapid periodicity requires that a large number of planes of symetry exists. These planes of symetry bound ple-shaped substructures, with the entire structure being a repetition of the geometry of these substructures. 
ORNL-OIG 76-2425
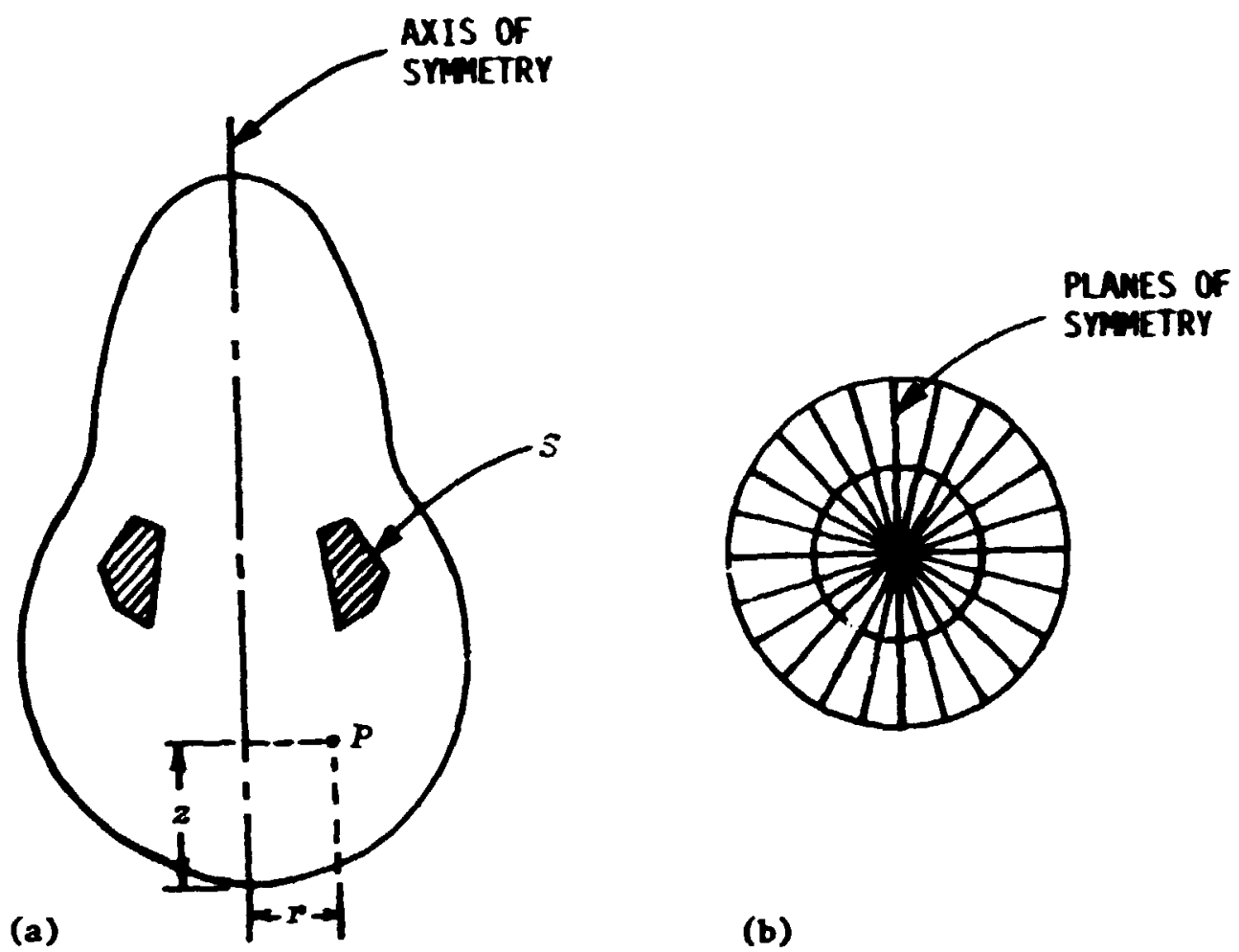

F1g. 1.16. A Structure with a Symetric Outiline. (a) Cross section. (b) View from above.

In perforning an axisymetric fintte-element analysis of the structure in FIg. 1.16, an elewent wesh is laid orst on the plane projection to cover the area to the right of the axds of symetry (P1g. 1.17). A group of these elements covers region $S$, in which swearing must be performed. For each elewent, the stress-strain relationship is described In terms of a metial metrix $[D]$ defined by

$$
\{\sigma\}=\{D]\{\varepsilon\}
$$

were $\{\sigma\}$ and $\{\varepsilon\}$ are colum vectors of streses and strains, respectively, for the element." In the axiaymetric problen, thera sre the three normal stresues - radial $\sigma_{p}$, axtal $\sigma_{z}$, and hoop $\sigma_{\theta}$ - and one shear component $\tau_{r z}$. The two thear components $\tau_{x \theta}$ and $\tau_{\theta z}$ are identically zero. 


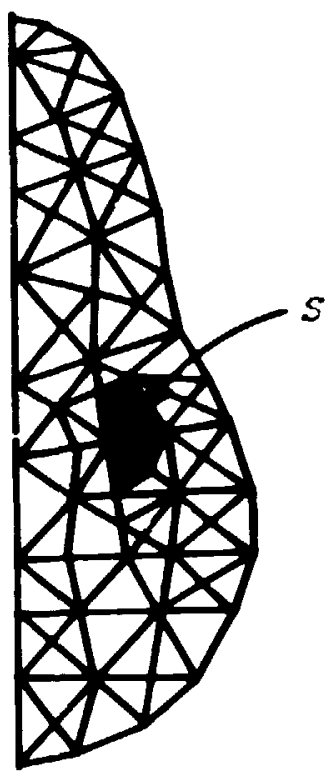

Fig. 1.17. Finite-Element Discretization of the Cross Section.

Sinflarly, there are four components of $\operatorname{strain} \varepsilon_{r}, \varepsilon_{z}, \varepsilon_{e}$, and $\gamma_{p z}$. Then $[D]$ is a $4 \times 4$ matrix. Using an indexial notation for stress and strain components in which 1,2 , and 3 are associated with $r, 3$, and $\theta$, respectively, Eq. (25a) can be uritten wre explicitly as

$$
\left.\left\{\begin{array}{l}
\sigma_{1} \\
\sigma_{2} \\
\sigma_{3} \\
\tau_{12}
\end{array}\right\}=\left[\begin{array}{llll}
D_{11} & D_{12} & D_{13} & D_{14} \\
D_{21} & D_{22} & D_{23} & D_{24} \\
D_{31} & D_{32} & D_{33} & D_{34} \\
D_{41} & D_{42} & D_{43} & D_{44}
\end{array}\right] \mid \begin{array}{l}
\varepsilon_{1} \\
\varepsilon_{2} \\
\varepsilon_{3} \\
\gamma_{12}
\end{array}\right) \text {. }
$$

Each colum of $[D]$ has a simple physical significance. The first colum $\left[\begin{array}{lllll}D_{11} & D_{21} & D_{31} & D_{41}\end{array}\right]^{T}$ is the stress response to the "unit strain loading" $\varepsilon_{1}=1, \varepsilon_{2}=\varepsilon_{3}=\gamma_{12}=0$, or $\{\varepsilon\}=\left[\begin{array}{llll}1 & 0 & 0 & 0\end{array}\right]^{T}$. In the same manner, each of the reaining three columns can be viewed as the stress response associated with a unit strain loading.

This concept will be used in smearing to produce a $[D]$ matrix for the elements in $S$. A homgeneous orthotropic material will be introduced to approximately represent this region in which aterial properties actually vary circumferentially. 
The acris $[S]$, defined as the inverse of $[D]$, also relates stress and strain for an element by

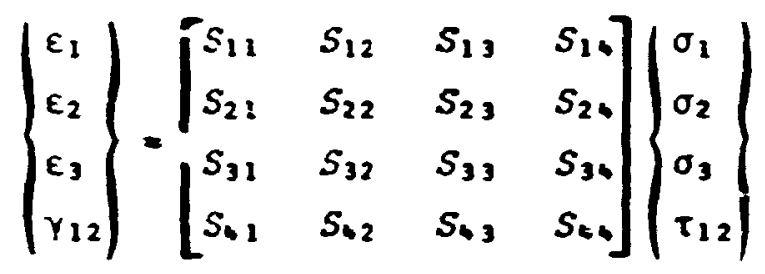

An orthotropic elastic meterial is described by the independent mterial constants $E_{11}, E_{22}, E_{33}, v_{12}, v_{13}, v_{23}, G_{12}$ that appear in the stress-strain relationships

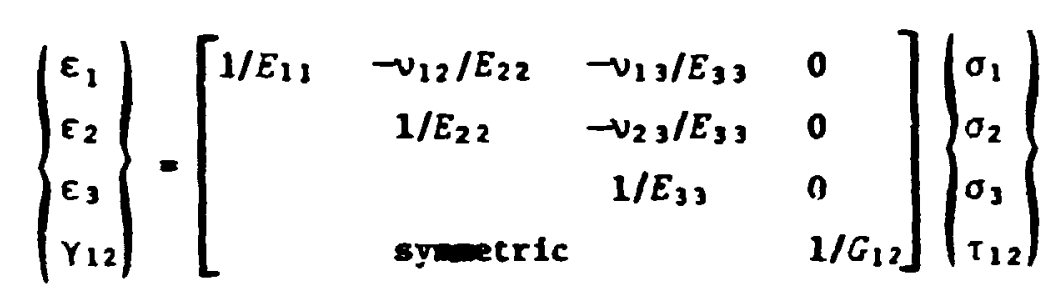

The axes of material orthotropy are $x_{1}, x_{2}$, and $x_{3}$.

Comparing Eqs. (26) and (27), these constants are related to the nemers of $[S]$ by

$$
\begin{aligned}
& E_{11}=1 / S_{11} \\
& E_{22}=1 / S_{22} \\
& E_{33}=1 / S_{33} \\
& v_{12}=-E_{22} S_{12}=-S_{12} / S_{22} . \\
& v_{13}=-E_{33} S_{13}=-S_{13} / S_{33} \\
& v_{23}=-E_{33} S_{23}=-S_{23} / S_{33} \\
& G_{12}=1 / S_{44}
\end{aligned}
$$

\subsubsection{Yethod 2 - Procedure}

The conceptual siages in the smaring process will now be described. Plgure 1.19(a) shows a pie-shaped substructure bounded by two adjacent planes of symetry intersecting at a sall angle $a$. In P1g. 1.18(b), a sma1l body with centrold $a t(r, z)$ and bounded by the planes of symetry 

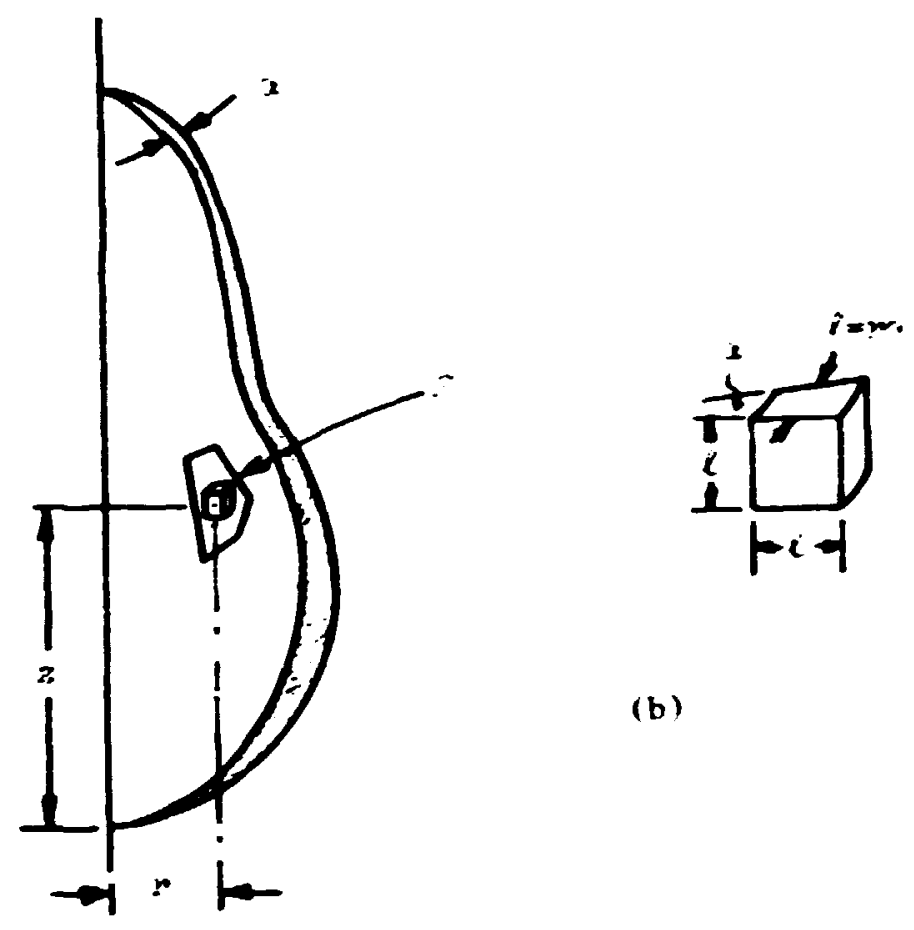

(a)

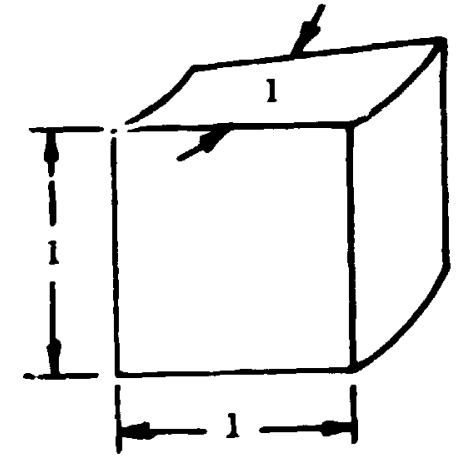

(c)

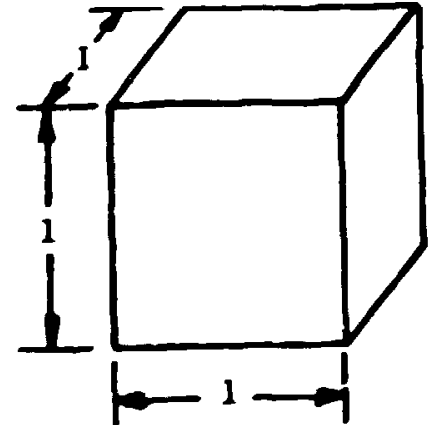

(d)

F1g..1.18. Conceptual Stages in Deriving a Unit Cube.

is extracted. Wo faces are squares with sides of length ra. Next the body is scaled up to unit dimenstong [F1g. 1.18(c)]. Since $a$ is sra11, th: wudy can be closely approximated by the cube of unit dimenslons shown in F1g. 1.18(d). 
This ualt cute is now constructed with parallelepiped finite elewents (Fig. 1.19). The internal elenent structure of the cube is as detailed as is required to adequately wadel the geometry of all or sone of the region spansed by $S$. The six faces of the unit cube are labeled as follows: F1 $(x=1), F Z(y=1), F\}(x=1)$, Fi $(x=0)$, FS $(x=0)$, F6 $(z=0)$. Each solid element composiag the unit cube is a six-sided parallelepiped with faces $f_{i}, f_{2}, f_{3}, f_{4}, f_{s}$, and $f_{6}$

OPen-DIs 76-2428

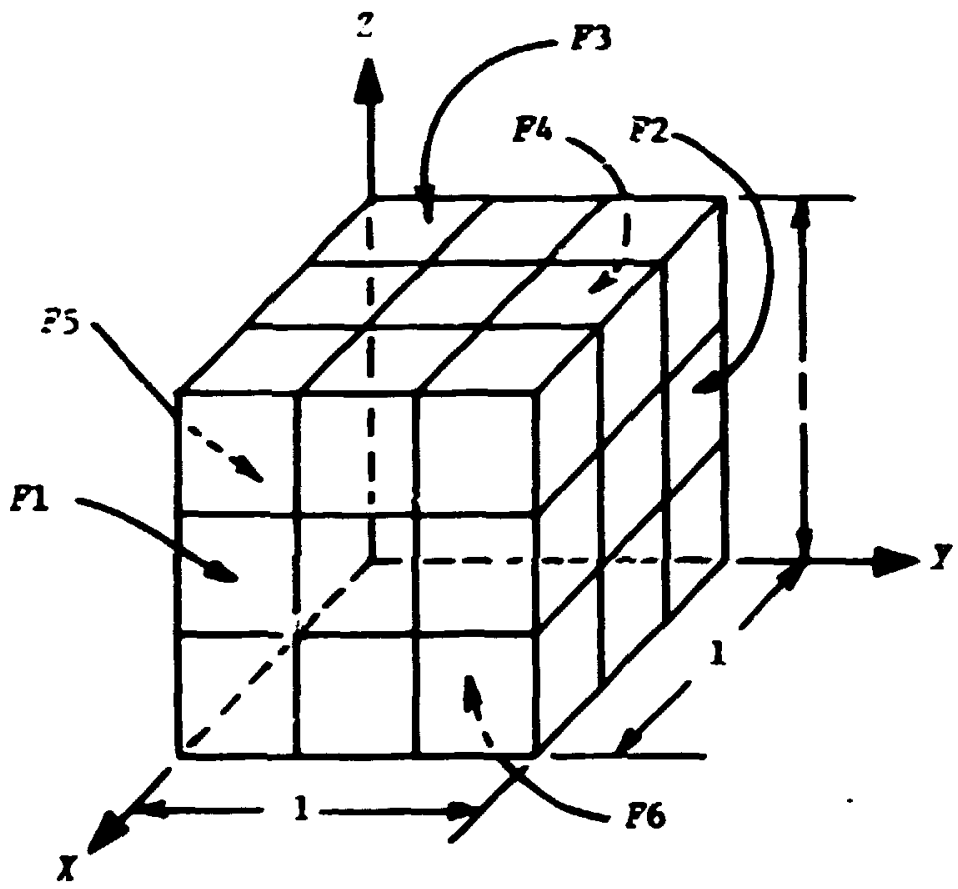

Fig. 1.19. Pinite Element Subdivision of the Unit Cube.

The unit cube is considered to be described by a [D] matix through

$$
\left[\begin{array}{l}
\sigma_{y} \\
\sigma_{z} \\
\sigma_{x} \\
\tau_{y 2}
\end{array}\right\}=\left[\begin{array}{llll}
D_{11} & D_{12} & D_{13} & D_{14} \\
D_{21} & D_{22} & D_{23} & D_{24} \\
D_{31} & D_{32} & D_{33} & D_{34} \\
D_{41} & D_{42} & D_{43} & D_{44}
\end{array}\right]\left\{\begin{array}{l}
\varepsilon_{y} \\
\varepsilon_{z} \\
\varepsilon_{z} \\
r_{y z}
\end{array}\right) .
$$


Comparing Eqs. (29) and (25b), $\sigma_{y}, \tau_{z}, \sigma_{x}$, ad $\tau_{y z}$ are playing the roles of $\sigma_{1}, \sigma_{2}, \sigma_{3}$, and $\tau_{12}$, respectively. Sinilarly, $\varepsilon_{y}, \varepsilon_{z}, \varepsilon_{x}$, and $Y_{y 2}$ play the roles of $\varepsilon_{1}, \varepsilon_{2}, \varepsilon_{3}$, and $Y_{12}$, respectively.

how by using a finite-element code to successively apply the four unt strain loading to the unte cube and by exanining some suitable definition of the streas vector $\left[\sigma_{y} \quad c_{z} \sigma_{x} \tau_{y z}\right]^{?}$ for the cube, wal wes can be assigned to $[C]$ colum by colum. The technique has been previously described and iplenented by loss." In this earlier work, the technique vas used to derive meroscopic orthotropic aterial properties for we in the three-dinensfonal analysis of composites.

The reminder of the procedure is difided into three stages:

(1) application of the unt strain loadings to the finite eleneat nodel, (2) calculation of che stress components on the cube in resposse to each unt strain londing, and (3) calculation of mterial constants needed for description of the sceared orthotropic meterial for a subsequent axisymetric analysis. The steps in this procedure have been previously described explicitly and are repeated here in light of chis new application. In a later section, the procedure vill be lllustrated vith a particular exaple.

\subsubsection{Application of the tintt Strain Loadings to the Finfte-Element Hodel}

A finite element code is used to apply the four unit strain loading cases to the cube and investigate the stress response. The procedure is now explained.

Hornal strains. The three normal strain loads $-\varepsilon_{x^{\prime}} \varepsilon_{y}$, and $\varepsilon_{z}-$ are applied in an identical fashion. The procedure will be described for the case of $\varepsilon_{x}$ and can be extended to the other cases by analogs. Referring to F18. 1.19, displece all nodes lying on F1 one unit in the positive $x$ direction. Simultaneously, restrain all nodes lying on $F 2, F 3, F 4, F 5$, and $F 6$ fron displacenent normal to their respective faces. No other restraints are placed on any nodes. The resulting configuration, shown in F1g. 1.20 , Is described by the strain state $\varepsilon_{y}=0, \varepsilon_{z}=0, \varepsilon_{x}=1, Y_{y z}=0$ as is destred. 
opere-0.56 76-2429

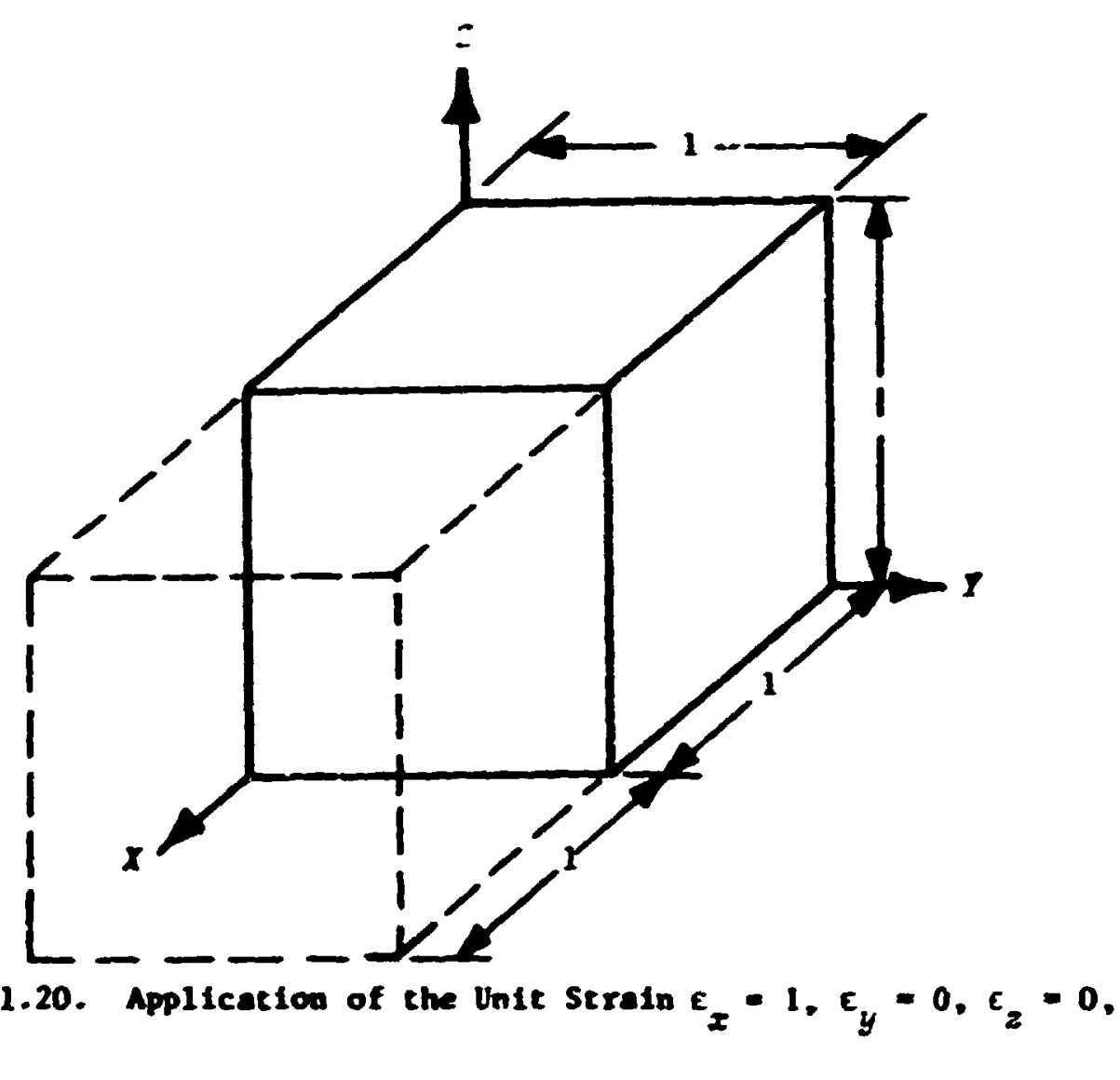

Shear strata. The procedure for applying a unit shear $\gamma_{y z}$ is now described. Referting apain to Fig. 1.19, displace all nodes in $F 2$ a itsence 0.5 in the positive direction, and displace ali noces on F3 - distance 0.5 in the postitve $y$ direction. Restraln all noder on $F$ and $F$ from displacement ncreal to their faces (x direction). Also, rastrain all nodes on $P 6$ from diaplacentent in the $y$ direction a: all nodes on BS fron dieplacement in the 2 direetion.

The configuration of the cube as a result of this procese to thown Ia P18. 1.21. The strain state is $\varepsilon_{y}=0, \varepsilon_{z}=0, \varepsilon_{x}=0$, and $\gamma_{y z}=1$. Fo: the mext stage in the process, it is conventent to have tios? finite-element code nutput stresses at the centroid of each of the i. $x$ faces of each element. The code STATIC SAP by U11son ${ }^{2}$ has this capintifty and has been used. The code vas coditied slightly to have the output pueched on IBY cards. 
ORPL-Ding 76-243?

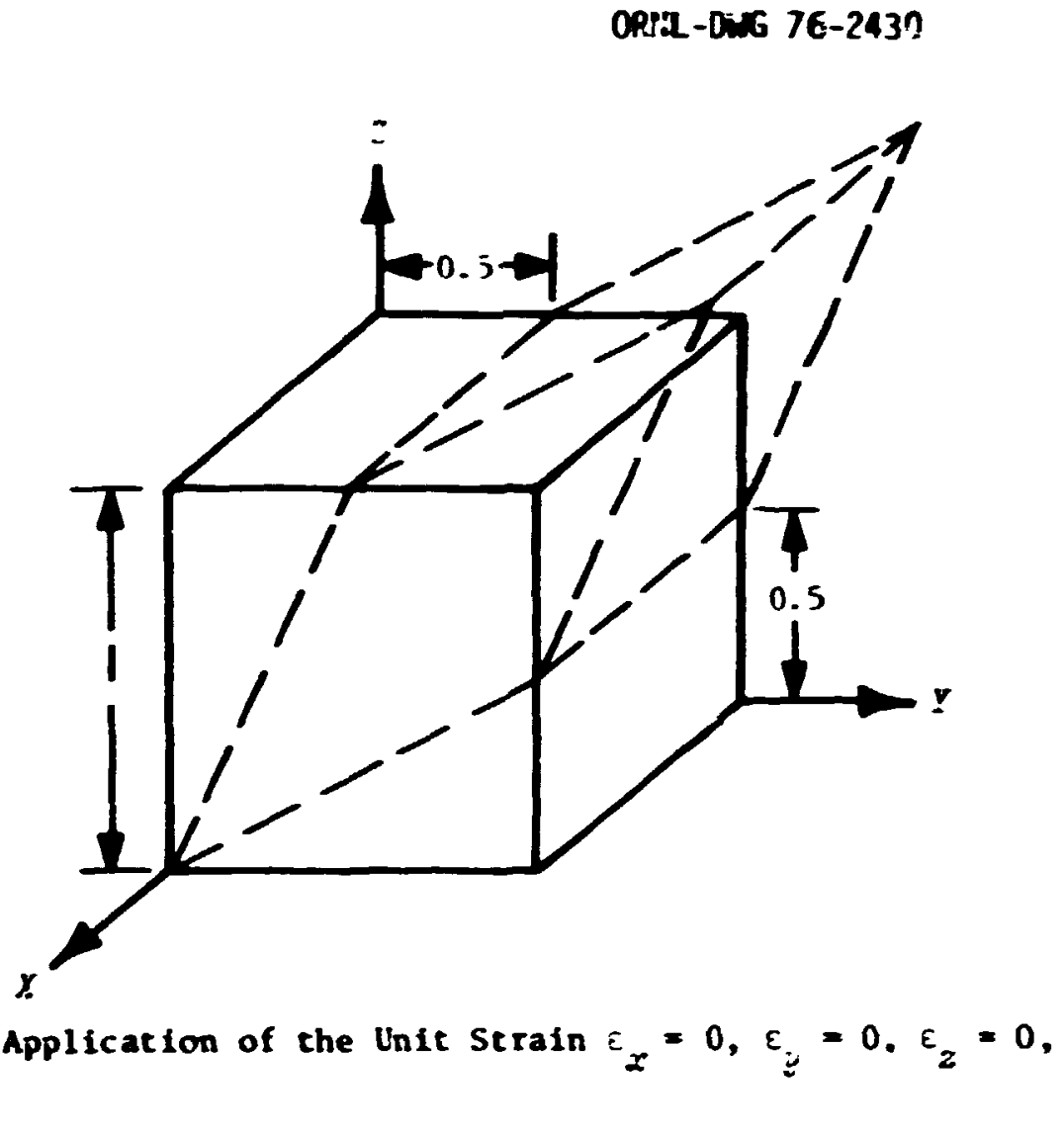

Fig. 1.21. Application of the Unit Strain $\varepsilon_{z}=0, \varepsilon_{z}=0, \varepsilon_{2}=0$, $Y_{z z}=1$.

\subsubsection{Calculation of the Stress Components on the Cube in Response to Each Unit Strain Loading}

In this second stage average stresses on the faces of the cube are computed from the output from stage 1 for each of the four loadings. Then for each loading, a colum of the $[z]$ matix is determined. Some notation is now introduced.

Let $a_{i, j}$ be the surface area of element $i$ contrfbuting to the face $F_{j}$ of the unit cube. The index $i$ ranges from 1 to $N$, where $N$ is the total numer of elements in the cube. Also, $;$ ranges from 1 to 6, corresponding to the $s i x$ faces of the cube. Thus $a_{i, i}$ equass the area of $f_{j}$ of the element for those elements that lie on $F_{j}$ of the cube. For elements not lying on $F_{j}, a_{i, j}=0$. Por example, referring to Fig-1.22, $a_{i, 1}$ has a value equal to the surface area of $f_{1}$ of clement $i$, whereas $a_{i+1,1}=0$. 


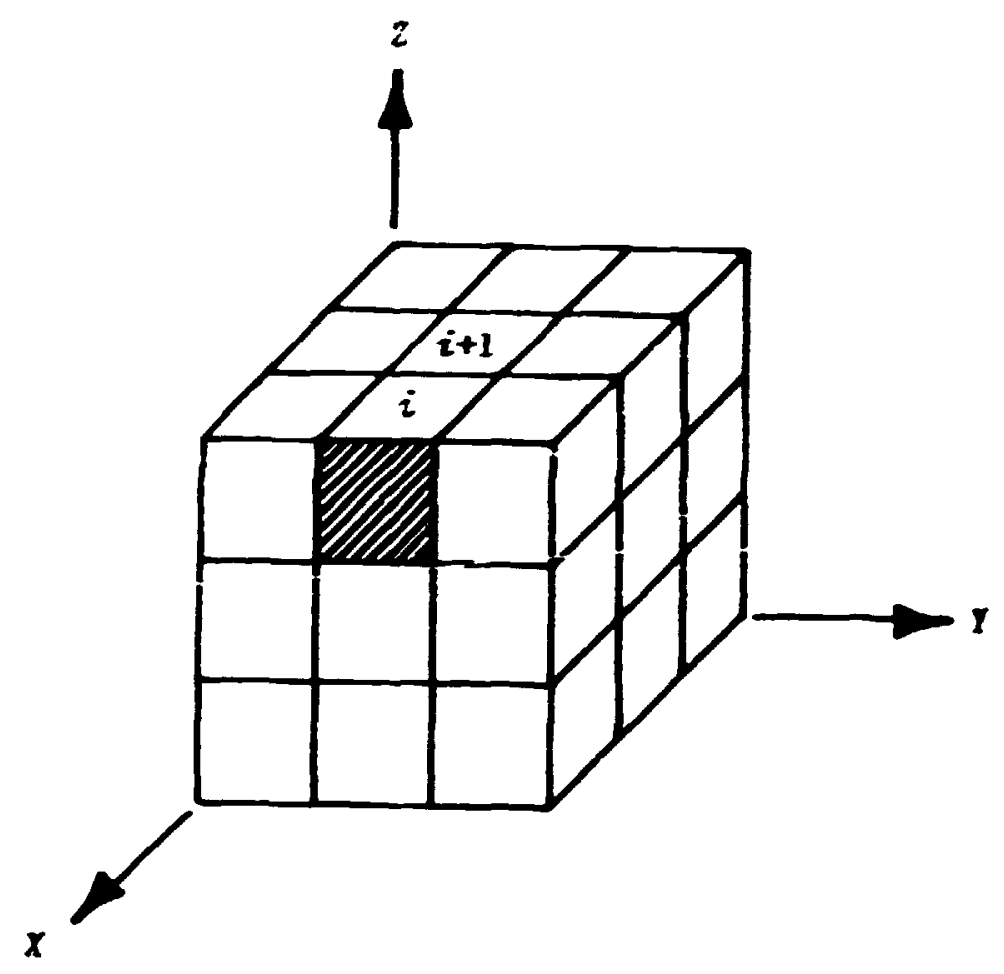

Fig. 1.22. $a_{i, 1}$ is Shown for the Unit Cube.

The quantity $A_{j}$ is the net surface area of $F_{j}$ of the unit cube. It is the sun of the contribution of the $M$ elements:

$$
A_{j}=\sum_{i=1}^{M} a_{i, j}, \quad j=1,2, \ldots .6 .
$$

We let $\sigma_{i, j, k, i}$ represent a component of stress at the centroid of $f_{j}$ of element $i$ in response to unit strain load case $i$, which ranges from 1 to 4 . As before, $i$ ranges from 1 to $M$ and $j$ from 1 to 6 . The subecript $k$ specifies the component of the stress tensor at that point, expressed in terms of the $x, y, z$ coordinate aysten of $\mathrm{P} / \mathrm{g} .1 .19$. The $81 x$ components are $\sigma_{y}, \sigma_{z}, \sigma_{x}, \tau_{y z}$ ' $\tau_{x y}$, and $\tau_{x z}$ for which $k$ has values $1,2,3,4,5,6$, respectively, Thus $\sigma_{2,3,3,2}$ represents the value of $\sigma_{x}$ at the centrold of face 3 of element 2 in response to unt strain loading 2, which is $\varepsilon_{y}=0, \varepsilon_{z}=1, \varepsilon_{x}=0, Y_{y z}=0$. 
linit mornel strain loadings. For each of the three mnei uni: strain ladings $(I=1,2,3)$, a colum of 3 elements of $[=],\left[\bar{F}_{1} \bar{z}_{2 l}\right.$ $\left.{ }_{3 i}\right]^{F}$, gets deterndined by computing the average norml stresses on the faces of the unit cube.

Let $Z_{j, i}$ be the net normel force acting on $F_{j}$ of the unit cube in response to load $i$. It is computed by suming the normal forces on $\tilde{i}^{-}$ of all elements lying on $F_{j}$ of the cube.

$$
\begin{aligned}
& \tau_{1,2}=\sum_{i=1}^{N} a_{i, 1} \sigma_{i, 1,3, i}, \quad \tau=1,2,3 ; \\
& i_{i, i}=\sum_{i=1}^{\varphi} a_{i, i} \sigma_{i, c_{1}, i-1, i}, \quad j=2,3,4 ; \quad i=1,2,3 . \\
& \because \therefore, i=\sum_{i=1}^{\ell} a_{i, i} \sigma_{i, i, j-4, i}, \quad j=5,5, \quad l=1,2,3 .
\end{aligned}
$$

Let $\Sigma_{j_{0}} z_{\text {be }}$ the net normal stress on $F_{j}$ of the unit cube for load case I, or

$$
\Sigma_{j, 2}=\tau_{j, 2} / i_{j}, \quad j=1,2, \ldots .6, \quad \therefore=1,2,3 .
$$

Stresses on opposite sides are averaged to get $L_{j I^{\circ}}$ The nine memers of $[\therefore]$ deterained from the three norwi unit strains are then

$$
\partial_{j i}=\left(\Sigma_{i, i}+\Sigma_{j+3,2}\right) / 2, \quad \quad \quad i=1,2,3, \quad I=1,2,3 .
$$

Unit shear strain loading. The fourth load case $(2=4)$ is used to deteraine $D_{44}$, relating $\tau_{12}$ and $\gamma_{12}$. The net shearing force on the cube involving $\tau_{12}$ is

$$
s_{j}=\sum_{i=1}^{M} a_{i, i} \sigma_{i, j, 4,4}, \quad j=2,3,5,6 .
$$


The average shearing stress on these faces is

$$
\Sigma_{i, 4}=s_{i} / A_{i}, \quad j=2,3,5,6 \text {. }
$$

Then $=44$ is the average of the shearing stresses on these four races.

$$
\Sigma_{46}=\left(\Sigma_{2,4}+\Sigma_{3,4}+\Sigma_{5,4}+\Sigma_{6,4}\right) / 4 \text {. }
$$

The remaining $s i x$ memers of $[D]$ are assigned the value zern, consistent with the representation as an orthotropic elastic material with axes of material orthot ropy coincident with the $r-\theta-z$ axes of the structure. So

$$
\begin{aligned}
& \Sigma_{i 4}=0, \quad j=1,2,3 . \\
& \Sigma_{42}=0, \quad i=1,2,3 .
\end{aligned}
$$

The resulting $[D]$ matrix will be found to be sumetric, with seven independent bers reflecting the seven independent elastic cunstants needed to characterize a homogeneous orthotropic elastic material:

$$
[D]=\left[\begin{array}{cccc}
D_{11} & D_{12} & D_{13} & 0 \\
& D_{22} & D_{23} & 0 \\
& & D_{33} & 0 \\
\text { symuetric } & & D_{44}
\end{array}\right] \text {, }
$$

1.3.3.3 Calculation of Material Constants Needed for Description of the Smeared Orthotropic Material for Subsequent Axisymetric Analysis

First $[S]$ is computed as the inverse of $[D]$ just obtained:

$$
[S]=[D]^{-1}
$$

The seven familiar , lastic constants are computed from $[\hat{\jmath}]$ using Eqs. (28). These are used for material description of the elements in $[i]$ of the structure to be analyzed axisymetrically. 


\subsubsection{Application of Method 2 to the Stean Generator Cavity Closure Plug Analysis}

The third design of the closure plug has been described in Sect. 1.2. The desigz is shown in Fig. 1.10 and the meshes used for the axisymetric solutions ete in Figs. 1.11 and 1.:2.

In the central porticn of the plug, an axisymetric steel conical section is atrached to the liner at the outside wall by forty 32-5thick (1 1/4-in.) gusse: plates. These plates introduce a significant deviation from axial symetry into the problem and necessitate smearing. The $r-z$ planes that pass through the center of these plates are planes of sym: $r y$, as are the $r-z$ planes that are equidistant from two adjaceni plstes. In fact, the plug can be considered as a periodic replication of pairs of irror-image pie-shaped segments, each bounded by two adjacent planes of symetry, intersecting at an angle $0 \% 4.5^{\circ}$. This illustrates the type of structure for which the method has been devised.

The code used for both the smearing analysis of the unit cube and the subsequent axisymetric analysis of the plu; was STATIC SAP. ${ }^{2}$ It is capable of handling general orthotropic elastic materials, and is suitable for the analysis of the smeared structure.

A unit cube was constructed with 12 eight-node brick linear isoparawetric elements (Fig. 1.23). The four steel elements representing the

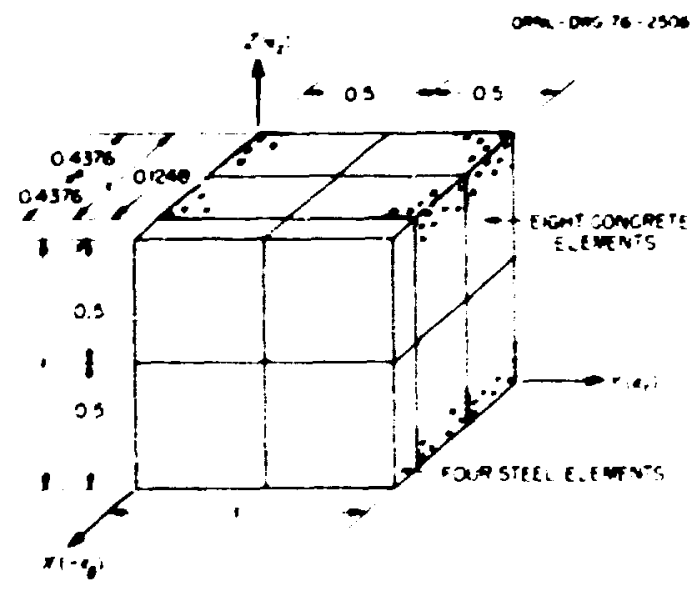

Fig. 1.23. The Unit Cube Used for Smearing in the Gusset Plate Region. 
gusset plate were assigned waterial properties $E^{B}=200.0$ GPA $(29.0 \times$ $\left.10^{6} \mathrm{psi}\right), v^{s}=0.29$. Of the $x$ (ctrcunferential) dimenston $12.487 \mathrm{tra}$ verses steel. This is a reasonably accurate estinate for the entire region $S$, so the $[D]$ mtrix obtained from this cube was used for all the elewnts. For the remining eight elements representing the concrete, the mterial constants used were $E^{f}=41.4 \mathrm{GPa}\left(6.0 \times 10^{6} \mathrm{ps} 1\right)$, $v^{c}=0.22$.

After the four unit strain loadings were applied, $[D]$ was obtained as

$$
\begin{gathered}
{[D]=\left[\begin{array}{cccc}
69.70 & 20.94 & 15.67 & 0 \\
20.94 & 69.70 & 15.67 & 0 \\
15.67 & 15.67 & 52.62 & 0 \\
0 & 0 & 0 & 24.52
\end{array}\right] \mathrm{GPa}} \\
=\left[\begin{array}{cccc}
10.1456 & 3.0365 & 2.2724 & 0 \\
3.0365 & 10.1456 & 2.2724 & 0 \\
2.2724 & 2.2724 & 7.6300 & 0 \\
0 & 0 & 0 & 3.5547
\end{array}\right] \times 10^{6} \mathrm{psi} .
\end{gathered}
$$

Then $[D]$ is inverted to get $[S]$, from which the seven merial constants are found to be

$$
\begin{aligned}
E_{11}=E_{22} & =61.25 \mathrm{GPa}\left(8.8807 \times 10^{6} \mathrm{ps1}\right), \\
E_{33} & =47.22 \mathrm{GPa}\left(6.8465 \times 10^{6} \mathrm{ps1}\right), \\
v_{12} & =0.24921, \\
v_{13}=v_{23} & =0.17239, \\
G_{12} & =24.52 \mathrm{GPa}\left(3.5547 \times 10^{6} \mathrm{ps1}\right) .
\end{aligned}
$$

Note that wdulus $E_{33}$ relating hoop stress to hoop strain, components normal to the gusset plate, has a value only slfghtly higher than that used for the concrete. Hodull $E_{11}$ and $E_{22}$, Involving normal stresses and strains in the plane of the plate, have higher values. Thus the preselice of steel is felt wre in this plane. 


\subsubsection{Seearing: Conclusions and Assessent}

An approxinte axisymetric solution to a compiex structural problea vas obtained at a nominal cost by use of swearing. Assuning the structure satisfactorily mets the two stipulated requirements, the swearing technique labeled Hethod 2 ensures that at any point $(x, z)$ in the cross section, the solution obtained gives the correct stresses, strains, and displacenents averaged over the circunferenct.

The question that then arises is to what extent the st:esses, strains and displacements at sone $f$ irticular cfrcunferential location $\theta$ aight deviate fron the computed averaged values. This question is difficult to answer with generality. For a given problen, however, wich light can be shed on this miter by perforning a two-dineastonal plane stress or plane strain analysis (whichever wore closely approximates the problen) of a cross section described by $z=$ constant and passing through the region $S$ in which swearing was performed. The procedure conceptually (Fig. 1.24) is to expose a circular cross section of interest, $z=$ constant, and lay out a two-dimenstonal mesh on the cross-sectional area bounded by two adjacent planes (Iines) of symetry.

The result will give a good indication of the expected deviation at difficent values of $\theta$ from che axisymetric solution. The deviation wil be wost sienificant at radial positions $p$ that lie in the smeared composite region where finfte jups occur in certain stress and strain quantities at aterial interfaces.

Stress and strains in the Individual meterial regions that compose the composite region replaced by a homgeneous smared aterial in the analysis are estiated numerically by treating quantities that are continuous in this region as being constants (independent of $\theta$ ). Those quantities that experience a discontinuity at aterial interface are treated as conatants within a given mterial, but the jump in value at the interface is taken into account.

This has also been applied to the plug structure of Fig. 1.10. Since the normal to the gusset plates in this problea is approxinately in the circunferential direction, hoop stress $\sigma_{\theta}$ is continuous across the steel-concrete interface. Strains in the p.lane of this interface $\varepsilon_{p}, \varepsilon_{z}$, and $\gamma_{r z}$ - are also continuous. Assuning these four quantities 

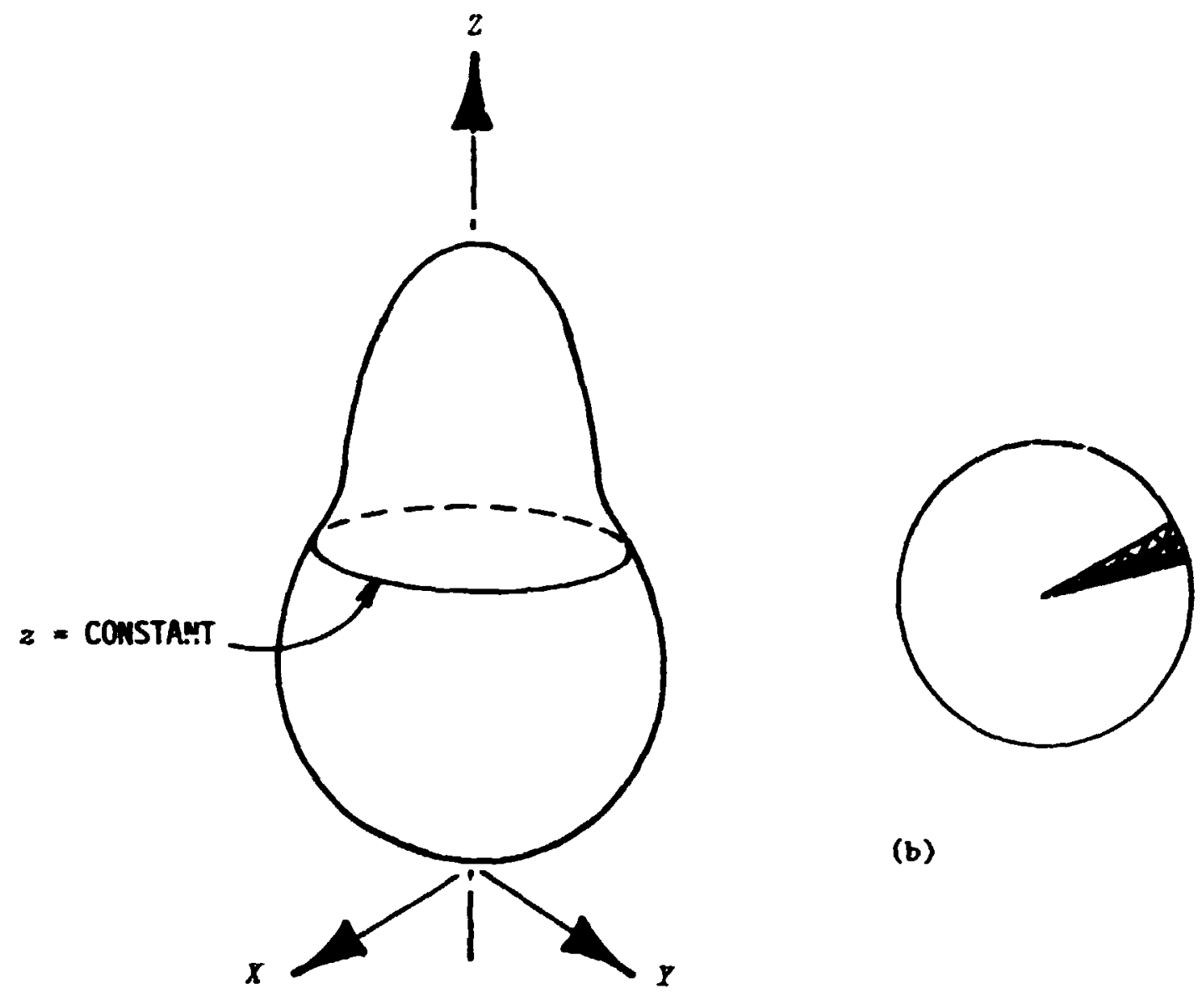

(b)

(a)

F18. 1.24. A Plane Stress or Plane Strain Analysis to Estimte Circunferential Variation in Behavior. (a) Cross section Imposed with $z$ = constant. (b) Mesh lafd out for a two-dimenstonal analysis.

to be constant, they are output directly from the axisymetric anilysis.

The discontinuous quantities are stresses $\sigma_{r}, \sigma_{2}$, and $T_{r z}$ and hoop strain $\varepsilon_{\theta}$. Designate these as $\sigma_{r}^{c} \sigma_{z}^{c} \tau_{r z}^{c}$ and $\varepsilon_{\theta}^{c}$ in the concrete and $\sigma_{r}^{8} \sigma_{z}^{8}{ }_{r}^{8}$ and $\varepsilon_{\theta}^{g}$ in the steel, all constants within their respective eacerials.

Hooke's law in the concrete gives

$$
E_{r}=\frac{1}{E^{c}} \sigma_{r}^{c}-\frac{\nu^{c}}{E^{c}} \sigma_{z}^{c}-\frac{\nu^{c}}{E^{c}} \sigma_{\theta}
$$


41

$$
\begin{gathered}
\varepsilon_{z}=-\frac{v^{c}}{E^{c}} \sigma_{r}^{c}+\frac{1}{E^{c}} \sigma_{z}^{c}-\frac{v^{c}}{E^{c}} \sigma_{\theta}, \\
\varepsilon_{\theta}^{c}=-\frac{v^{c}}{E^{c}} \sigma_{r}^{c}-\frac{v^{c}}{E^{c}} \sigma_{z}^{c}+\frac{1}{E^{c}} \sigma_{\theta}, \\
r_{r z}=\frac{2\left(1+v^{c}\right)}{E^{c}} \tau_{r z}^{c} .
\end{gathered}
$$

Equation (38d) yields

$$
\tau_{r 2}^{c}=\frac{E^{c}}{2\left(1+v^{c}\right)} \gamma_{r 2}
$$

The remaining three equations can be rewritten in the form

$$
\left[\begin{array}{ccc}
\sim^{c} / E^{c} & \sim^{c} / E^{c} & -1 \\
1 / E^{c} & \sim^{c} / E^{c} & 0 \\
v^{c} E^{c} & 1 / E^{c} & 0
\end{array}\right]\left\{\begin{array}{l}
\sigma_{r}^{c} \\
\sigma_{z}^{c} \\
\varepsilon_{\theta}^{c}
\end{array}\right\}=\left[\begin{array}{l}
\left(-1 / E^{c}\right) \sigma_{\theta} \\
\varepsilon_{r}+\left(v^{c} / E^{c}\right) \sigma_{\theta} \\
\varepsilon_{z}+\left(v^{c} / E^{c}\right) \sigma_{\theta}
\end{array}\right],
$$

with the solution

$$
\begin{gathered}
\sigma_{r}^{c}=\frac{E^{c}\left(\varepsilon_{r}+v^{c} \varepsilon_{z}\right)+v^{c}\left(1+v^{c}\right) \sigma_{\theta}}{\left[1-\left(v^{c}\right)^{2}\right]}, \\
\sigma_{z}^{c}=\frac{E^{c}\left(\varepsilon_{z}+v^{c} \varepsilon_{r}\right)+v^{c}\left(1+v^{c}\right) \sigma_{\theta}}{\left[1-\left(v^{c}\right)^{2}\right]}, \\
\varepsilon_{\theta}^{c}=\frac{\left[1-3\left(v^{c}\right)^{2}-2\left(v^{c}\right)^{3}\right] \sigma_{\theta} / E^{c}-v^{c}\left(1+v^{c}\right)\left(\varepsilon_{p}+\varepsilon_{z}\right)}{\left[1-\left(v^{c}\right)^{2}\right]} .
\end{gathered}
$$

Similarly, the quantities in steel are

$$
\begin{gathered}
\tau_{r z}^{\delta}=\frac{E^{3}}{2\left(1+v^{\delta}\right) r_{r z},} \\
\sigma_{r}^{8}=\frac{\delta^{s}\left(\varepsilon_{r}+v^{8} \varepsilon_{2}\right)+v^{8}\left(1+v^{8}\right) \sigma_{e}}{\left[1-\left(v^{8}\right)^{2}\right]},
\end{gathered}
$$




$$
\begin{gathered}
\sigma_{2}^{8}=\frac{E^{8}\left(\varepsilon_{2}+v^{8} \varepsilon_{r}\right)+v^{8}\left(1+v^{8}\right) \sigma_{\theta}}{\left[1-\left(v^{8}\right)^{2}\right]}, \\
\varepsilon_{\theta}^{8}=\frac{\left[1-3\left(v^{8}\right)^{2}-2\left(v^{8}\right)^{3}\right] \sigma_{\theta} / E^{8}-v^{8}\left(1+v^{6}\right)\left(\varepsilon_{r}+\varepsilon_{2}\right)}{\left[1-\left(v^{8}\right)^{2}\right]} .
\end{gathered}
$$

If the elastic analysis is to be followed by a time-independent inelastic analysis with say plasticity and concrete cracking, it is tempting to reuse the sase wesh with smeared material constants for an axisymetric inelastic analysis. The onset of these inelastic phenonena occurs at locations of peak values in stresses or strains. If on the basis of a cross-sectional plane stress or plane strain analysis it is concluded that the stresses and strains depend on circunferential location only locally in the smeared region $S$ and its inediate vicinity, and If in this region it can be shown that the condition for the onset of Inelastic behavior will not be aet, then one can soundly proceed with an axisy-etric analysis.

Quite obviously, this smearing technique can be applied to a variety of composite structural features. Two examples that are planned for GCPR closure plug work are an array of axisl hole penetrations and an orderly array of reinforcenent bar aligned radially and axially.

\subsection{PLANING OF EXPERILATTAL MDDEL TESTS}

$A$ series of 1/15- and 1/4-scale codel tests will be conducted on both the stean generator cavity closure plug and the reactor cavity closurz plug. The relative dinenslons, tolerances, and wechanical properties of the prototype will be codeled as closely as practicable. Because of the sall physical size of the 1/15-scale nodel relative to the avallable iniature strain gages, the regions of highest strain gradient will not be accurately measured. Consequently, the 1/15-scale wodel tests will be used to dewonstrate gross structural behevior and to provide the information required to maximize the effectiveness of the wre costly 1/4-scale codel studies. 


\subsubsection{Test Plan}

The following procedure is being followed in conducting tests of the 1/15- and 1/4-scale closure plug models.

1. Design and fabricate codel test fixture. A single 1/15-scale and a single 1/4-scale test fixture should suffice for all the tests.

2. Design and fabricate closure wodels.

3. Set up test facility and instrument model.

4. Conduct test. Pressure w111 be cycled fron zero to maximan cavity pressure (HCP) ten times; pressure will then be increased monotonically until gross faflure occurs or until capacity of the test fixture and/or testing facility is reached. Once the elastic range is exceeded, but the applied pressure does not exceed the design pressure, the strain in the concrete at the top and botton of the closuras and the deformations will be masured to establish that the stresses do not exceed the calculated peraissible linit values. We will also ascertain whether the deforations are reverstble upon reduction of pressure. The behavior of the closures will then be studied by increasing the pressure in sufficiently sall steps uf to ultiate failure so that the linit of deformation reversibility and the variuus phases of fallure can be detected and the ultinate pressure capacity establi=hed.

5. Analyze data and report conclustons.

The order of testing will be: (1) 1/15-scale stean generator cavity odel, (2) $1 / 15$-scale central core cavity wodel, (3) $1 / 4$-scale stean generator cavity wodel, and (4) 1/4-scale core cavity node1, with steps 1 through 5 betng repeated for each nodel. Depending upon avallable funding certain steps can be permitted to overlap chronologically.

Acceptance criteria for a plug are that the nodels exhibit a strength equal to or excerding a $30.2 \mathrm{MPa}$ gage (4380 psig) pressure loading (3.0 MCP), that the elastic deformations are tolerable, and that failure is progressive (gradual).

\subsubsection{Destign of the Test Fixture}

The first test to be performed is a 1/15-scale model of the stean generator cavity closure plug shown in Fig. 1.10. Although the present 
design calls for both primary and secondary hold-down systems, the first planned test deals exclusively with the structural benavior of the plug under priarry hold-durn.

Several conceptual desigas of the 1/15-scale closure model test fixture have been examined with the objectives that the priary hold-down coggle reaction orientation and location be realistically scaled and that a test fixture pressurization capability of $138 \mathrm{BPa}$ gage $(20,000 \mathrm{psig})$ be attained. These objectives are premised on the viewpolnt that realistic codeling should be exployed and that the test fixture should have an appreciable pressurization capability in excess of anticipaced model failures. Ho atterpt will be ade to duplicate support comliance; the codel support must of necessity be overdesigned to accomodate the anticipated loadings asscriated with fallure of the plug.

The space linitations ilposed by geometric features of the odel prohibit long toggle nemers as appear in the actual prototype holddown system. An amenable arrangement that will simulate this system exploys a ring of spherical balls arranged in a configuration sintlar to a conventional ball thrust bearing except that each ball and its spherical seat are independent from the remirder of the set. The balls in this arrangement are linited to approximately $9.5=(3 / 8 \mathrm{In.)}$ in diameter. An analysis using ASHE Section III Nuclear Cocie rules assuning use of AISI 52100 balls with a hardress of $R_{c} 58$ predicted that such an arrangement is unsatisfactory. However, a sinilar analysis of test data by SXF Industries, Inc. on crushing load of balls loadzd in a three-ball configuration indicated that the analytical model is grossly conservative. Consequently, to verify the applicability of the conceptual arrangement, a scieening test was run on 9.5 and 12.7-m-dian ( $3 / 8$ - and $1 / 2-i n$.$) balls, and then further verification tests were conducted with.$ three 9.5-m-dian (3/8-in.) balls and associaled seats. In the latter cests a load of $0.22 \mathrm{kN}(50,000 \mathrm{lb})$ (load cell linitation) was applied to the ball seat arrangenents without causing fallure of the balls or seats. The balls flowed plastictally with deformations typically of $\pm 0.08-( \pm 0.003 \mathrm{in.})$. Compliance at the 0.22-14 $(50,000-1 \mathrm{~b})$ load level 
was typically $0.53=(0.021$ in.). Hydrostatic loading was essentially achieved with the resulting average calculated uniaxial compressive stress of $3.10 \mathrm{GPa}(1,50,000 \mathrm{ps} i)$ being well in excess or typical strength levels obtained for uniaxial specimens.

These data and the proposed unceptual arrangement were discussed at the March 25 meting with General Atonic personnel in La Jolla, Califfornia. The adaptation of the concept to the loading fixture was approved. Subsequently layouts of the test fixture parts were initiated. The resulting test fixture systen is show in Fig. 1.25.

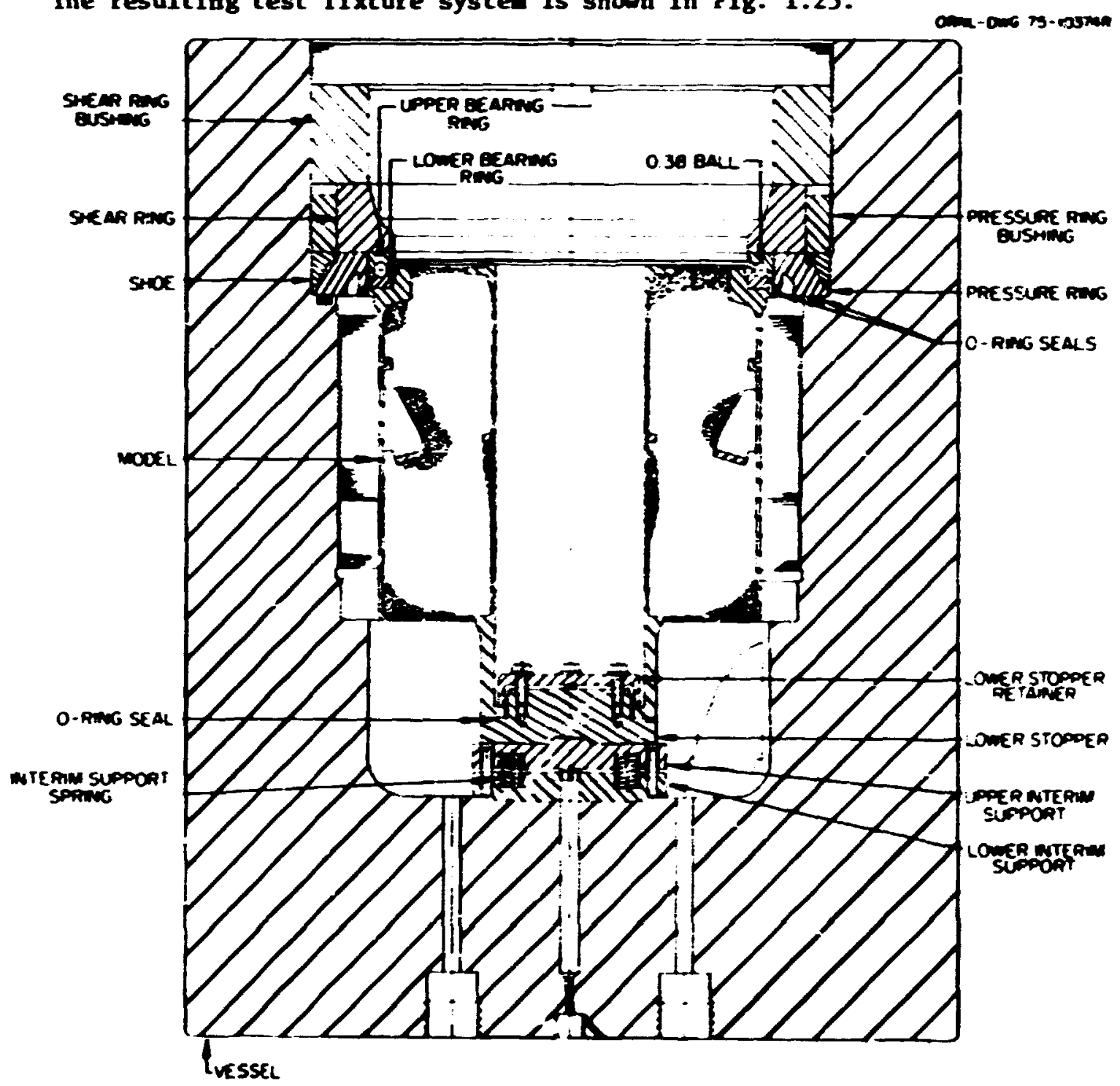

F1g. 1.25. Scale Stean Generator Cavity Closure Model Test Assemoly Cross Section. 
At this point, plane stress analysis and an axisymetric elastic finite-element analysis were performed on the proposed test fixture holddown systen, Fig. 1.25. The systen was analyzed for $6.9 \mathrm{MPa}$ (1 ksi) operating pressure with the code CRERP-PLAST. ${ }^{\prime}$ The analysis was to verify chat the structural integrity of the system will be mintained for overpressure loadings of up to $138 \mathrm{kPa}$ (20 ksi). The analyses were interpreted in accordance, ith the design rules of Section III, ASIE Boller and Pressure Vessel code, in order to neet internal oRul requirenents for pressure vessels.

The wesh show in Fig. 1.26 consisting of 744 constant-strain triangles and 423 codel polats, was used for the analyses. The assuned loading conditions are $6.9 \mathrm{HPa}$ (1 ksi) pressure applied to the lower surface of the pressure ring, and a concentrated 44.00-kl (9891-1b) force Inclined at $25^{\circ}$ fron the vertical and applied to the ball [44.00 kN/radian ( $9891 \mathrm{lb} / \mathrm{radian}$ ) in the axisymetric analysis]. This loading represents the resultant force produced by the $6.9 \mathrm{kPa}$ (1 kst) pressure acting on the plug wodel. The aterial properties used were those of the BI-100 forging being procured for the test fixture. The following inportant factors were considered in our developent of the analytical odel:

1. Plane stress axionetric solution. The solution obtained for plane stress neglects hoop stress. The shear ring is segnented with no guaranteed contact between adjacent segnents; thus, plane stress is - close approximtion of the state of stress in this case. The remining systea concaents, facluding the hold-dow bushing, are essent fally contiarus axdoymetric rings. By coupling the plane stress analyois with the axdsymetric analysis, one can place bounds on the hold-down systen behavior. For the inediate purpose of evaluating comliance with the ASTR Code requirenents, we feel that a plane strese malyst. In which hoop stress is neglected and redial and axial stresses are exaggerated affords a conservative estiate.

2. Distribution of nodal polats. Mdjecent parts of the systen share comon nodal points; that is, the systeo is nodeled as a single contlauou body. Two conditions generally occur at she coatact surface 


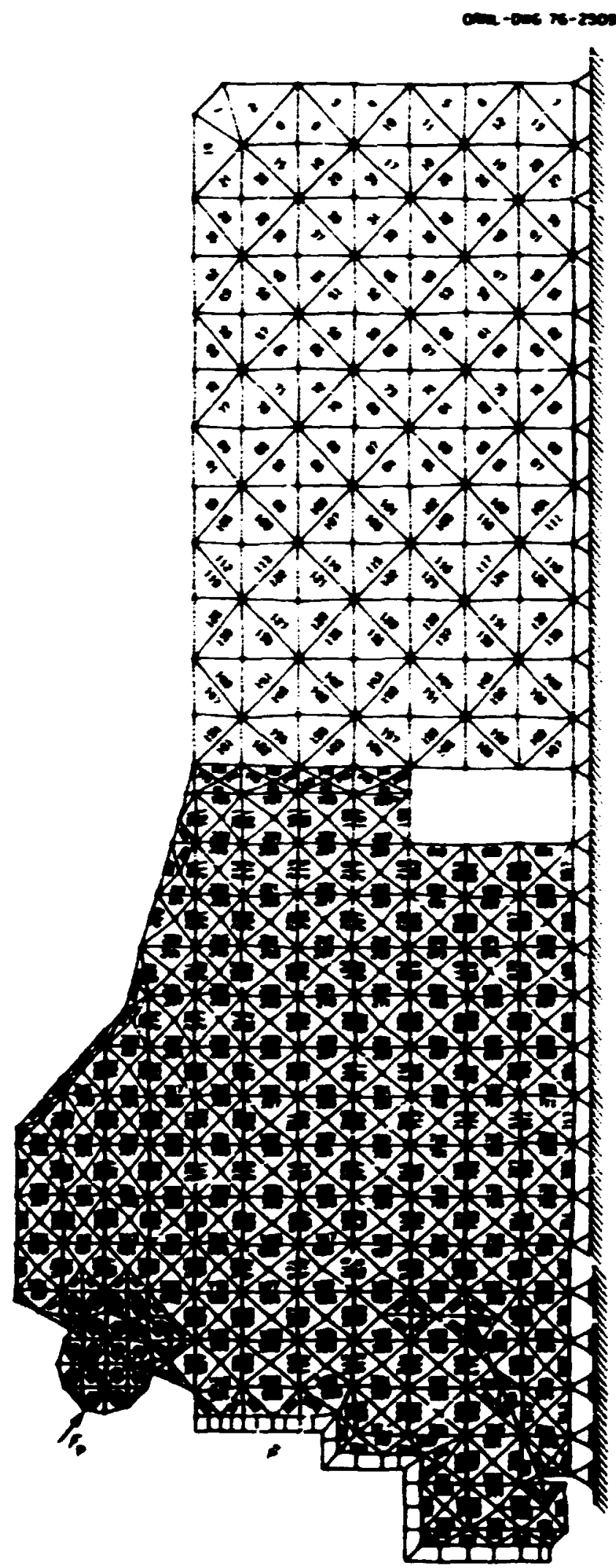

Fig. 1.26. Finite-Element Hesh of 1/15-Scale Sten Gearertor Cavity Hodel Hold-Darn System. 


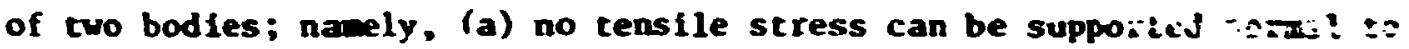
the cor:tact surfaces since separation of the parts would resilt, and (b) upon faftation of slippage, the shear stress on the contact surfaces of both bodies is equal to the product of the coeffictent of friction tives the ncrial contact stress.

Condition (a) introduces no complications since normal cotizet stresses at all surfaces are compressive. However, the shear stress condition does constitute an oversifflification since wre load is transnitted between adjarent parts via shear stress in this analytical model than would actually occur.

3. Boundary conditions. The boundary condit fons are somewhat idealized in this analytical codel, as no displacement is peraitced along the walls of the bushinge, were in actuality they are threaded into the vessel. The nodal points along these edges are assumed by the analysis to be simply supported. Also, no friction is adarted along the outer surface of the shoe, which is located below these bushings and in contact with the vessel. These particular nodal points are on rollers free to translate axially.

The output has been exanined in light of the ASHE Sect. III rules. The parts were adequately proportfoned to satisfy the selected desfgn objective of $138 \mathrm{xPa}$ gage $(20,000 \mathrm{psig})$ at room temperature, thereby achieving a sizeable margin above the minime pressure requirenent of 3 MCP or 30.2 IPa gage ( $4380 \mathrm{ps} \leq 8)$ to ensure that the ultimate load of the closures 111 be deternined.

\subsubsection{Instruneatacion and Fabrication of the Test}

The systea of Fig. 1.25 will shortly be under coastruction. The pressure loading will be applied hydrostatically. The nodel will be Instrumented with weldable strkin gages so the surface and eabedwent gages in the concrete. Also, deflection wil be masured on the surface with displacement gages. The finite-elewent walyses of Sect. 1.2 are ueed in positioning these gages and determining approxinate mgnttudes of strains and displacenents to be exsured. 
Instrumentation accessibility will be provided to pressurized surfaces of the ndels. Access will be through the botton of the cest fixture. Four autoclaved lead-through fitcings will be orovided; each permits passage of eight comercial mineral-insulated, three-wire 1.5-m dian. (0.060 in.) stainless-steel-sheathed therwocouple leads. These fittings have been verified for $276 \mathrm{MPa}(40,000 \mathrm{psi})$ pressures at resperatures ranging from 0 to $88^{\circ} \mathrm{C}\left(32-190^{\circ} \mathrm{F}\right)$.

Detailed crawings of the systea have been cospleted. The necessary merial has been procured, and a cost estimate for fabrication is in pricess. The 1/15-scale test will be conducted in an existing shielded test pit in Builds̄ing $\mathbf{5} 201-3$ of the Y-12 Plant. This facility has been previously used' for testing of $0.15-w_{\text {-dian }}\left(6-1\right.$ in.) $^{\prime}$ steel vessels to pressures of approximely 24C $\mathrm{APa}(35,000 \mathrm{psig})$.

\subsection{REFEREMCES}

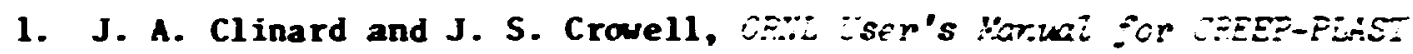
Conujer Erczrar, ORNL-TH4062 (Novemer 1973).

2. E. L. Wilson, "Report for Finite Element dnalysis of Mine Structures to Denver Mining Research Center," U.S. Department of Interior, Bureau of Mines, Contract No. 40110231, September 1972, Departzent of Civil Engineering, University of Califomia, Berkeley.

3. J. M. Coru and J. E. Smith, use of Smaii Mcleis ir. Eesion ari Anaizsis of Prestressed iorcrete leactor iessels, ORKL-4346 (May 1970).

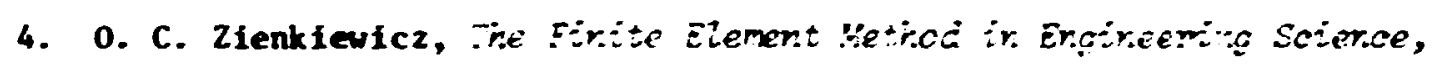
HeGraw-Hill, New York, 1970, p. 20.

5. E. L. Hilson, "Report for Finite Element Analysis of Mine Structures to Denver Mining Research Center," U.S. Departmert of Intertor, Bureau of Mines, Contract No. 40110231, September 1972, Department of Civil Engineering, Lifiversity of California, Berkeley, p. 91.

6. A. L. Ross, "Designing with Three-Ditectional Composites," Mech. Eng. $97(4)$ ) 32-37 (April 1975).

7. R. W. Derby, J. C. Merkle, G. C. Robinson, G. D. Whitaan, and F. J. Hit:, Tex of 6-incti-Thick Pressure iessels. Serieg it Intermedinte fest Vesbe!s V-1 and $V-2$, ORN,-4895 (February 1974). 


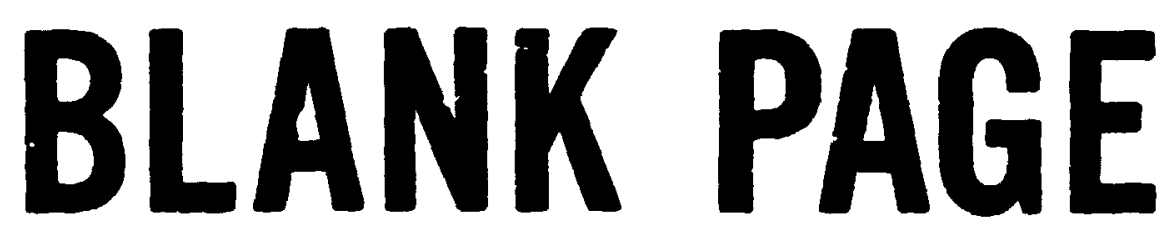

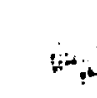




\section{GCFR IRRADIATION EXPERIMENTS}
J. A. Conlin
A. U. Longest

\subsection{IMTRODUCTION}

A series of fuel-rod irradiation tests has been conducted at ORNL in support of fuel development for the Gas-Cooled Fast Breeder Reactor (GCFR). The GCFR is being developed at General Atomic Company (GA) with support fros the Energs Pesearch and Development Administrat:on (ERDA) and a number of eiectric utility companies. The fuels-irradiation progran for the GCFR consists of both thermal- and fast-flux testing in capsule and loop experiments. Theraal-f lux tests are being performed at ORWL in a series of capsule tests in the Oak Ridge Research Reactor (ORR) poolside facility. These cests, supported by ERDA, represent the conbined efforts of GA, ORNL, and Argonne National Laboratory (ANL).

Two fuel-rod concepts for the GCFR have been investigated in the ORWL thermal-flux tests: a sealed fuel rod and a vented-and-pressureequalized fuel rod. Earlier tests of 20 fuel rods of the sealed type (ORR capsules $\mathrm{P}-1$ through $\mathrm{P}-8$ ) indicated this concept to be a feasible backup design; however, cladding temperatures and dimensions must be carefully specified and controlled to ensure that cladding ovality and subsequent failure by localized cladding collapse do not occur under the high coolant pressure ( $9 \mathrm{MPa}$ ) in the GCFR.

The current irradiation test, capsule GB-10, and the preceding one, capsule GB-9, were designed to permit an initial evaluation of the overall perforwance of the vented-and-pressure-equalized fuel rod, which is the reference fuel-rod design for the GCFR. Many important aspects of the GCFR pressure-equalization system ${ }^{2}$ are also being studied in these tests. The GB-9 and GB-10 experiments have provided substantial in:ormation ${ }^{2-13}$ on the fission-prcduct-release and fuel behavior to be expectad from the GCFR vented fuel rod. The experimental data have been used in many aspects of the GCFR pressure eoualization system design and in computer models for predicting fast breeder reactor fuel performance. 
Postirradiation exanination of the GB-9 fuel rod, which was irradiated at $48.6 \mathrm{kH} / \mathrm{m}(14.8 \mathrm{kH} / \mathrm{ft})$ peak power to a fuel burnup of approximately $54 \mathrm{Md} / \mathrm{kg}$-heavy metal, has beer. completed at ANL and GAC. '11;

The GB-10 fuel rod, similar to GB-9 but designed with greater capability for measuring fission product release and transfort, is being irradiated in three successive peak pover steps: $39.4,44.3$, and $48.6 \mathrm{~kW} / \mathrm{m}(12,13.5$, and $14.8 \mathrm{~kW} / \mathrm{ft})$ at peak cladding outer surface terperatures of 565,630 , and $685^{\circ} \mathrm{C}$, respectively. The estimated burnup of the GB-10 fiel rod on June 25, 1975, (708 days irradiation) was $70 \mathrm{rud} / \mathrm{kg}$ heavy metal. The original burnup goal of $75 \mathrm{mud} / \mathrm{kg}$ has been extended to $100 \mathrm{md} / \mathrm{kg}$ to permit additional experimental weasurements.

The GB-10 neasurements are a continuation of the measurements started with capsule GB-9. The GB-9 capsule, being the first of a ind, yielded a large amount of information, particuiarly for the soreal operating conditions of a GCFR fuel rod. The GB-10 capsule, with its additional sweep lines, permits experiments of greater depth involving both normal and of f-nomal conditions. The main objective of GB-10 is to obtain detailed information on the release, transport, and trapping of gaseous and volatile fission products. Another objective is to observe the general performance of chs rod and to look for any behavior that could be a potential problem for the GCFR.

Capsule GB-10 has provided, for the first cine, direct measurements of the release of gaseous and volatile fission products from the solid matrix of an operating fast breeder reactor fuel rod. Another notable accomplishment of $\mathrm{GB}-10$ has been the measurement of flow conductance through the fuel rod, while operating at power, as a function of burnup.

Because of the need for additional experimental data that only GB-10 could provide at the present time, the GB-10 measurements and goals were expanded during the course of the irradiation. During the current report perfod, three systems were installed to increase GB-10 capability for study of fission product release and transport. These were (1) an online $\mathrm{Ge}(\mathrm{L} i)$ gamma-ray detector system, which permits easier and more detailed fission gas release measurements; (2) a system for taking large $(\approx 1-1$ iter $)$ gas samples for the detemination of stable noble-gas 
release rates using mass spectronetry; and (3) a systen for senicontinuous measurement of the tritiun coutent in the ef fluent steep strean.

\section{$2 . \overline{2}$ DESCRIPTION OF CAPSULE GB-1O}

The GB-10 fuel rod (Fig- 2.1) is a shortened prototype of the GCFR rod with a $0.2 j-1008$ (9-in.) region of sol-gel-derived (U, $\mathrm{Pu})_{2}$ soild pellet fuel, a 51-a-long (2-in.) upper blanket region of depleted $\mathrm{UO}_{2}$ pellets, and a 25.4-m-long (1-in.) charcoal trap. The two $\mathrm{VO}_{2}$ halfpellets at each end of the nixed-oxide colun were included to suppress power peaking at the ends of the rest fuel. Initial oxygen-to-netal ratios $(0 / \mathrm{M})$ were 1.98 in the $(\mathrm{U}, \mathrm{Pu}) \mathrm{O}_{2}$ pellets, 2.004 in the $\mathrm{UO}_{2}$ halfpellets, and 2.002 in the depleted $\mathrm{vo}_{2}$ blanket pellets. Fuel colum smear density was 84.22 of theoritical. The charcoal trap contains 0.4618 of activated coconut charcoal, type M-6736. The cladding is 207-culd-wrked stainiess steel with a roughened outer surface.

The fuel rod is show inside the instrumented GB-10 capsule in Fig. 2.2. The Nak-filled capsule is equipped with an electrical heater formed into a coil over the upper blanket and trap regions of the fuel rod. The charcoal trap temperature can be contrciled over the range 200 to $400^{\circ} \mathrm{C}$ by adjusting the outpit of the heater. The fuel region power level is controlled by adjusting the capsule position in the ORR poolside facility (1.e., adjusting the distance from the reactor core). Thirteen thrmocouples conttor cladding temperatures along the rod. Fuel region pover profiles are estimated from the thermocouple indications by use of heat transfer equations. Additional details of the capsule and fuel rod design were reported previously. 10,11

The GB-10 arrangement of sweep lines and valves (F1g. 2.3) peraits flow across the top of the fuel rod, which is the normal sweep flow wode, or f low through the three wain regions of the rod (trap, blanket, and fuel), either individually or in combination. As shown in Fig. 2.3, we have designated the sweep lines as follows: $B F=1$ ine to botton of fuel, TT - lines to cop of charcoal trap, BT - line to botcon of trap, and $B B=$ line to botco of upper blanket. Specific sweep flow modes are designated by two letters indicating the entrance point followed by two 
DANL- OWG 71-1370SR

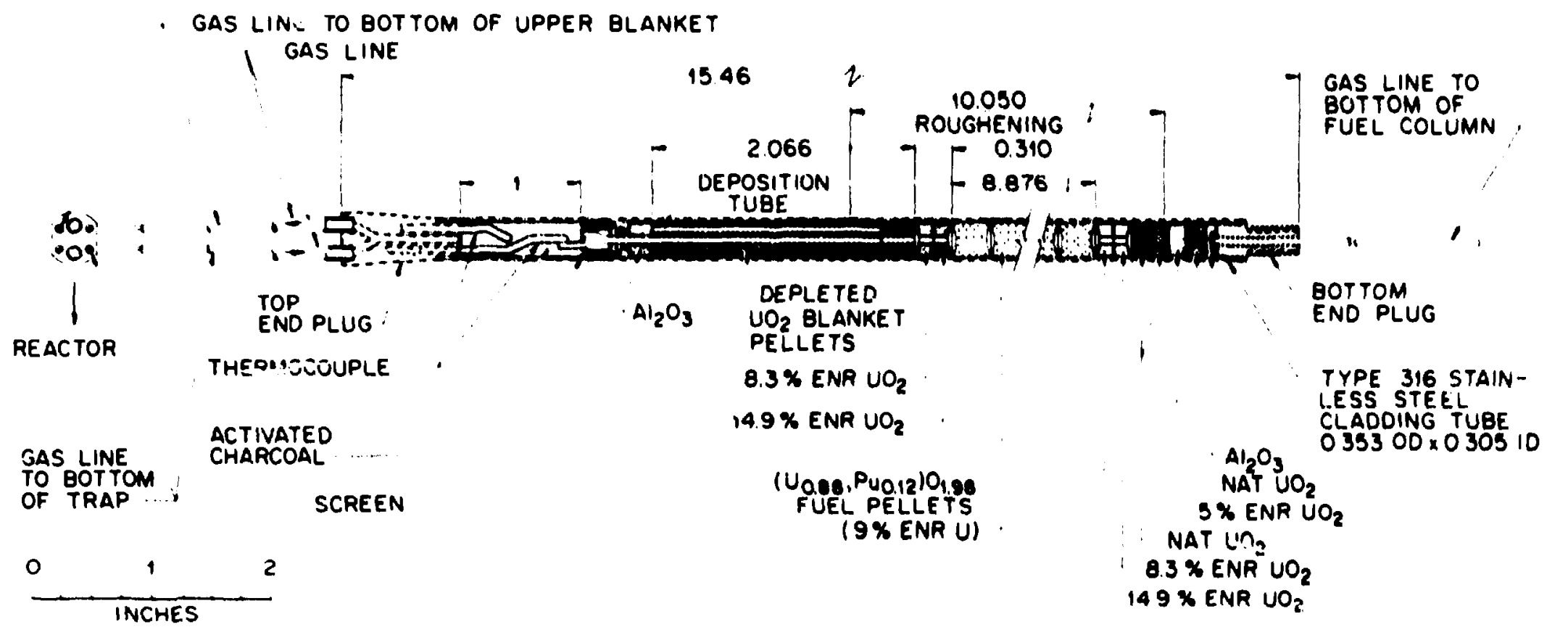

ALL DIMENSIONS IN INCHES

F18. 2.1. Fuel Rud Specimen for Irradjacion in GCFR-ORR Capsule GB-10. To convert dimensions to millimeters, multipl; by 25.4 . 


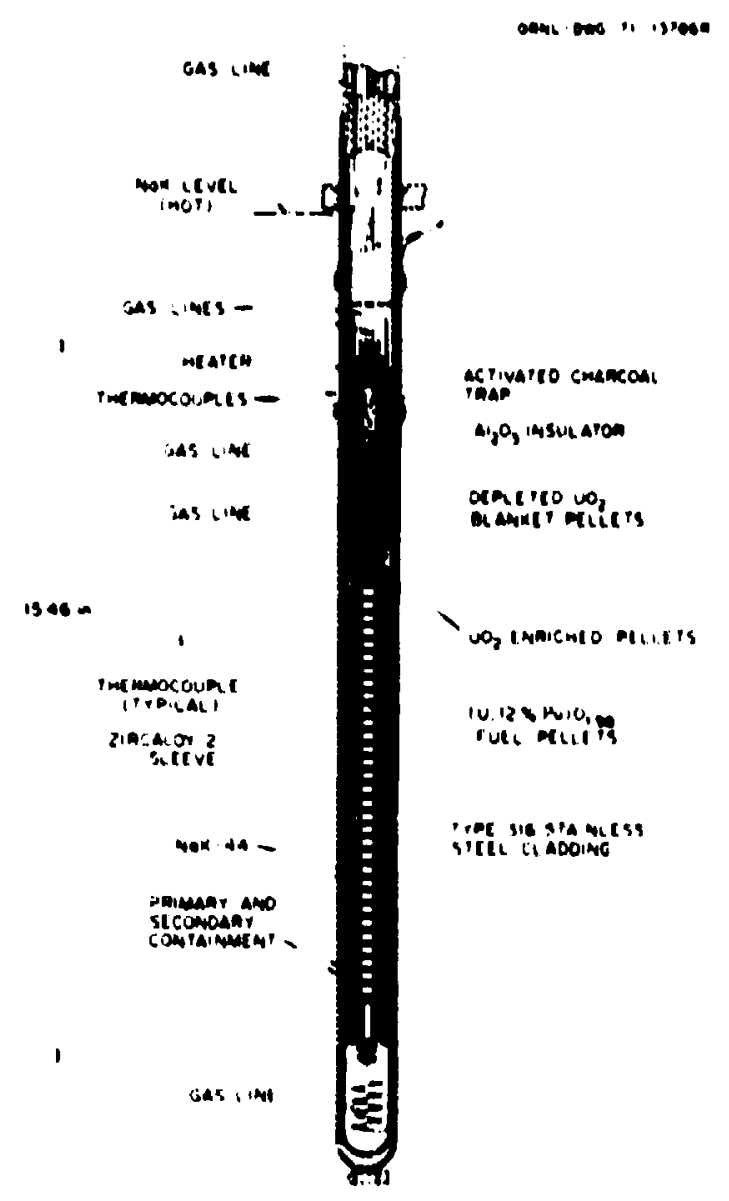

F1g. 2.2. GCFR-ORR Capoule GB-10. Helght Indicated $18392.7 \mathrm{~mm}$

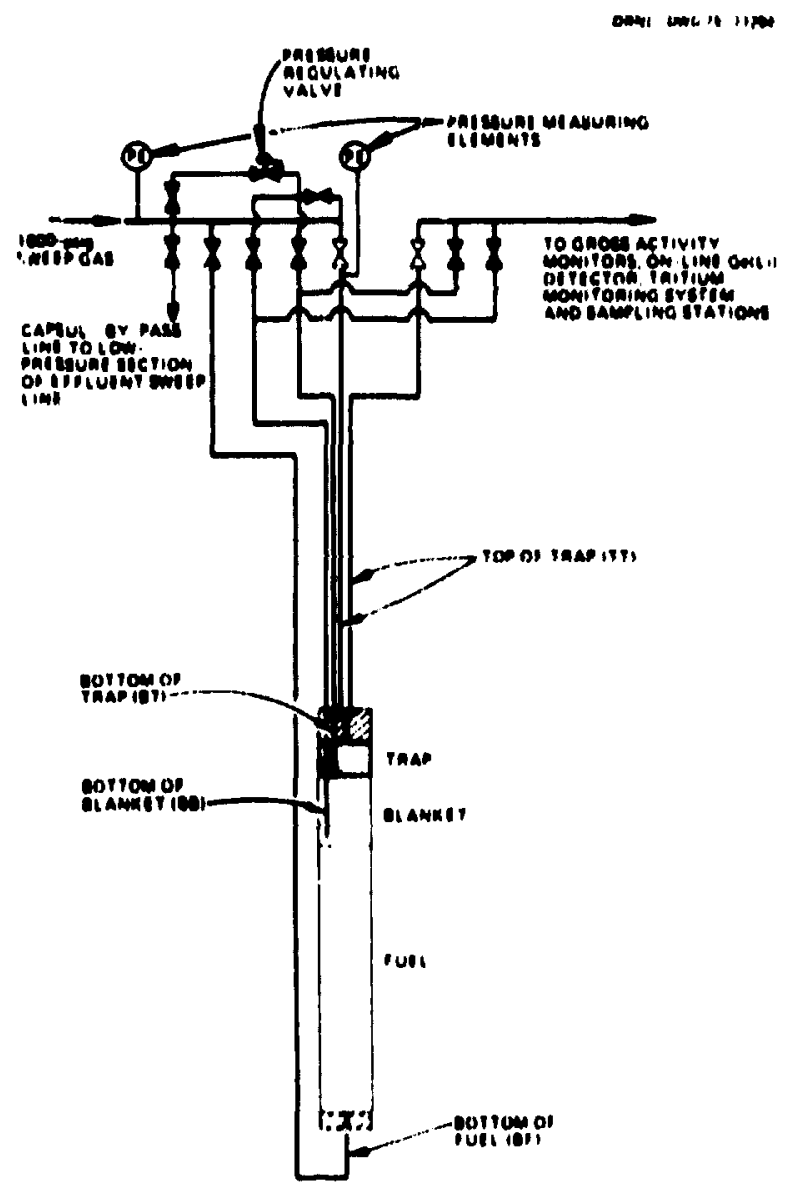

F18. 2.3. Schemat1c of GCFR-ORR Capsule GB-10, Showing Sweep Gas Lines. 
core letters indicating the exit point irom the fuel rod. Thus, wien the sweep $f$ low is directed across the cop of the rod, the flow wode is IT-IT and when the sweep flow is directed into the botcon and out of the top of the rod the flow mode is BF-Ti. The latter flow mode (BF-TT; simulazes a leak in the cladding of a GCFR fuel rod.

Twe of the lines shown in Fig. 2.3, the one with the pressure regulating valve and the capsule bypass line, were recently added to the system to aid in making fission-gas release measurenents at very low flow rates through the fuel region of the rod.

The sweep and cladding-externai gas sysiens for capsule GB-10 are shown in Fig. 2.4. Flow through the sweep system (0.15-1.3 std litersi nin) is regulated $b_{j}$ adjusting the downstrea flow resistance with a needle valve. Flow restrictors are eaployed inediately upstrean of the needle valve to limit the flou rate out of the systen to a maxima value. An automatic pressure differential control valve adjusts the inlet sweep flow and maintains the sweep pressure $172.4 \pm 0.7 \mathrm{kPa}$ ( $25 \pm 0.1 \mathrm{psi})$ above the oressure in che normaliy stacic claddingexternai gas system. Analyzed helium is used as the sweep gas and is passed through room-tenperature molecular-sieve iraps and then through $625^{\circ} \mathrm{C}$ citanium-sponge traps before going to the capsule.

At the start of the $C B-10$ irradiation, $f$ ission-gas release was mitored by two on-line ionization chabers and by gama-ray spectrometry of gas samples taken perindically. The on-line ionization chambers, one located on the high-pressure section of the effluent sweep line and the other on the low-pressure section, coriinuously monitor the gross activity of the sweep line and provide a sensitive indication of the steadiness of $f$ ission gas release from the rod. Since the start of the GB-10 irradiation, three additional fission-product monitoring systems have beer, designed and installed. An on-line Ge(Li) gama-ray decector system (see Fig. 2.4) was added to the high-pressure section of the effluent sweep system to permit easier and wore detailed fission gas release measurements. The other two systems, both added to the lowpressure section of the effluent sweep system, are one for taking large gas samples for determination of stable krypton and xenon release rates and one for monitoring tritium. 


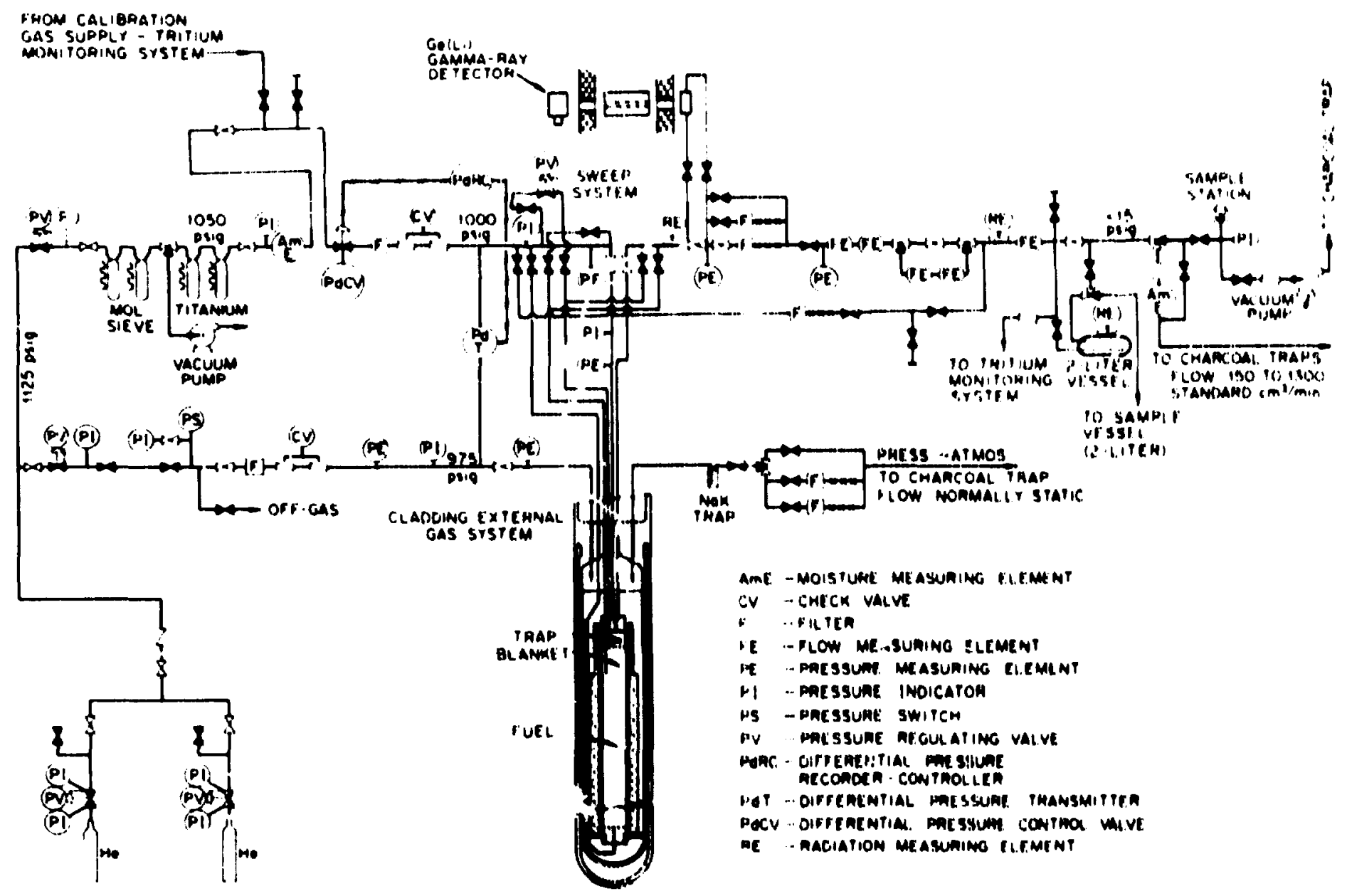

F18. 2.4. GCFR-ORR Capbule GB-10 Sweep and Cladding-Externhl-Gan Syatema. 
The GD-10 on-line gama-ray spectroneter syste consists of a 6. 35-m-ID (0.25-in.) source section in the effluent sueep line, five $0.305-1008$ (12-in.) stainless-steel-lined lead collinators raugins from 1.6 to $32=$ ID (1/16-1 $1 / 4$ in.) to cover the vide activity range associated with the various GD-10 flow modes, a Ge(LI) detector (8.62 efficiency for "(Co) vith associated Dewar and power supply, preasplifier located at the detector, ain aplifier located at the analyzer, and a luclear Data $50 / 50$ data acquisition systen (PDP-15 computer interfaced with a 4096-chasmel analyzer). The separation distance betreen the source section and the detector (center-line-to-center-line) is 0.597 . (23 1/2 in.). Before installation, the detector systen was calibrated with each of the collimators in place with an exact wokup of the actual experimental setup and calibrated radionuclide sources.

A schenatic of the syste for taing large suples for stable noble gas (SnG) release deternination is show in Fig. 2.5. In taking these saples, we direct the effluent sweep flow through the shielded 2-1iter vessel inside the shielded value box for an appropriate length of time

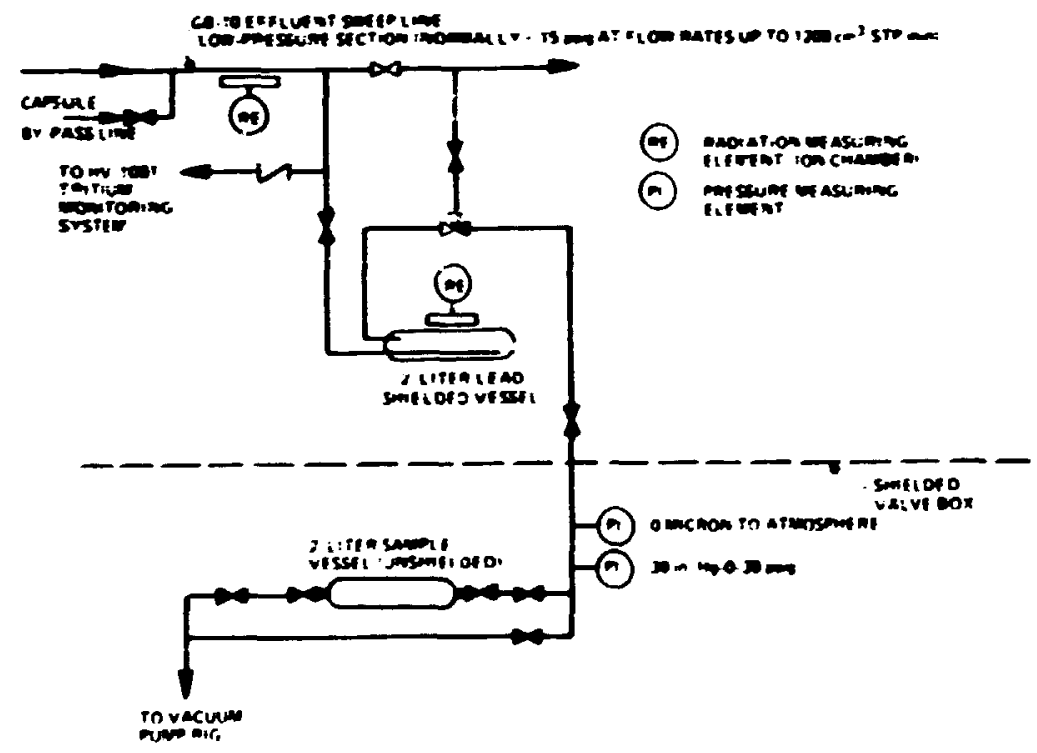

Fig. 2.5. Schematic of Capsule GB-10 Sampling System for Stable Noble Gas Release Determination. 
(abcut 10 voluse chames) and then trap a saple of the gas to the ressel. The sapple is allowed to decay for 6 weeks, and then about half of ic ( $\approx$ l sed liter of gas) is dran of inco a clean 2-liter saple vessel outside the valve box. The Sing suple is then renoved and prepared for analysis by ass spectronetry. Special techniques are required to concentrate the krypton and xenon isotopes to measurable levels.

The Go-10 tritiu maitoring systen (Fig. 2.6) is desigmed to messure the tritiu ( $T$ ) concentration in the effluent sweep gas inder various capsule operation conditions and sweep flow nodes. In addition, provision is ade for introducing BT-in-He calfbration gases (at four different tritiu concentrations), either directly to the tritiun conitoring systen for calibration checks nr to the GB-10 inlet sweep systea for taition transport experiments. The same gas supply manifold my be used to introduce other prenixed gases to the inlet sweep systen when desirable.

The main components of the $i:$ itiu monicoring systen are a Bro-to-fir converter (agnesiun at $500^{\circ} \mathrm{C}$ ), a liquid-nitrogen-cooled charcoal trap

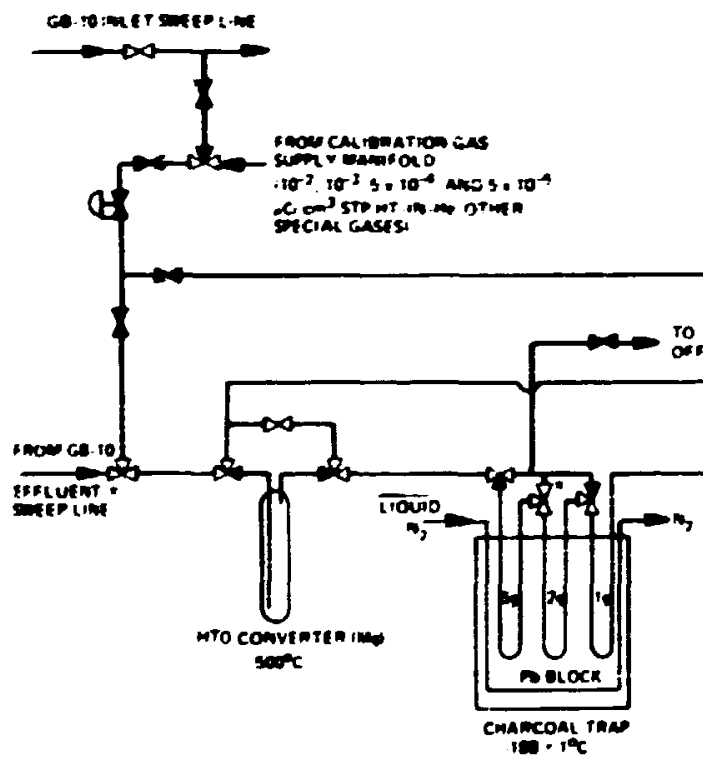

F1g. 2.6. Schematic of Capsule GB-10 Tritium Monitoring System. entariaconorions

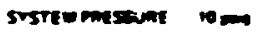

tenciar. in as morto

sostrorion aAtés

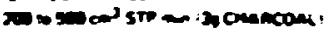

s0.

mortans:
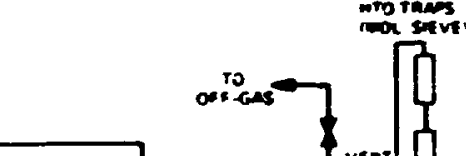

\section{icess}
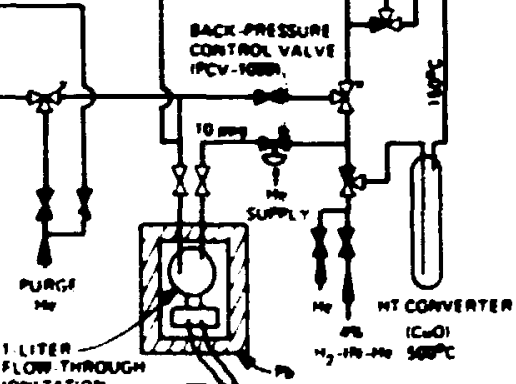

rov. Tminough conzafrom

vieararing atco 
asseably (charcoal at $-188^{\circ} \mathrm{C}$ ), a cal ibraced flow-tbrungh ionization ch-ber and vibrating-reed electroneter, an tr-to-tro converter (CuO at $500^{\circ} \approx$ ), and a renovable tro trap assebbly (eoleculia sieve). Sucep gas from the capsule floss through the charcoal trap designed to delay all radioactive gases but trition for loas periods relative to the tine required for the neasurenents. Tritiv conteat in the gas strem iaving the charcoal trap is thea decervined by observinis the respoase of the calibraced ion chmber and by batchuse collection and analysis of tritiu using the rewovble ino traps and beta liquid scintallation zounting methods. The batchuse sapiting nethod is used as needed to verify and/or supplewent the ion chaber data. The im-to-il converter upstrea of the charcoal trap enables weasurement of lotal critiu whes it is valved in and only gaseous tritium shen it is valved out, since the charcoal uil trap the eoisture form. The charcoal trap was performancecested and the lor chaber was calibrated before installation in the system. The other main components were simulated in laboratory-scale experinents to verify cheir design.

Tritil monicoring experiments are plamed to cbtain information on crition release rates from the mixed-oxide fuel pellets, relative cladding-permeation and venting rates from the rod fuel, eolecular form (HT and/or HTO) of the released tritiun, and the effect of low levels of $\mathrm{H}_{2}$ and $\mathrm{H}_{2} \mathrm{O}$ in the sweep gas on criciu cransport behavior in the fuel-fission-product-heliu environent. To fully understand trit transport behavior in the $\mathrm{CB}-10$ systea way require injecting $\mathrm{H}_{2}$ and $\mathrm{H}_{2} \mathrm{O}$ into the inlet sweep gas to decermine their influence on tritiun transport. Before any injections of this type are nade, however, the existing levels of $\mathrm{H}_{2}$ and $\mathrm{H}_{2} \mathrm{O}$ in the nomal sweep 825 are to be decermined, and the effect on fuel and fission product cheafstry of any planned changes In impurity ievels is to be evaluated.

Instruments for determining the $\mathrm{H}_{2}$ and $\mathrm{H}_{2} \mathrm{O}$ contents in the sweep gas upstream and downstream of the capsule are currently being evaluated and calibrated in laboratory tests. A refrigerated moisture generator is also being tested in the same setup to determine its feasibflity for adding $\mathrm{H}_{2} \mathrm{O}$ to an inlet sweer gas of known $\mathrm{H}_{2}$ content and to control the 
$\mathrm{H}_{2} \mathrm{O} / \mathrm{B}_{2}$ ratio in the $\mathrm{gas}$. Preparation of the GB-10 systen for It:allation of these composents has started.

\subsection{IRADLATIOH COADITIOAS FOR CAPSULE GB-10}

The irradiation of capsule reb-10 in the Oar poolside ids. itty us started in August 1972, at a fuel-rod peak power level of 39 ; $14 / \mathrm{a}$ (12 kd/ft) ( $565^{\circ} \mathrm{C}$ peak cladding outer surface teperature). peration at $39.4 \mathrm{~kW} / \mathrm{e}$ ws cancimaed to an estinated fuel burnup of $27 . .^{\circ}$ ud/kg beavy netal. The fuel-rod power was thea raised to $44.3 \mathrm{~kW} / \mathrm{m}(? . .5 \mathrm{kH} / \mathrm{ft}$ ) i6 $30^{\circ} \mathrm{C}$ peak cladding outer suriace tepperature), where of ation has concinued satisfactorily to the present burnup level of $70 \therefore i / k g$ an ine 25 , 1975. Following complezion of plamed experimencs at 4: $3 \mathrm{kH} / \mathrm{a}$, the pourer will be increased to $48.6 \mathrm{kH} / \mathrm{g}(16.8 \mathrm{kH} / \mathrm{ft})\left(685^{\circ} \mathrm{C}\right.$ pear jadding outer surface cemperature) for the reminder of the irradiar $2 a$. The fuel burnup goal has been revised from its original value of 7 : to $100 \mathrm{vud} / \mathrm{kg}$.

Operating conditions for the fuel rod are lista in Table 2.1. These conditions are cypical of thuse expected for a GCFR : sel rod except for tix absence of significant fast-peutron exposure. : weep flow is anincained when $\rightarrow$ or the capsule is at power, so that $f i$ ision gases way be free to diffuse out of the fuel rod as in the cay of the G'FR rod. The irradiation is interrupted ocsasionally for shor periods for reactor iefueling shutdowns (a few hours once every tuc eeks) and reactor endof-cycle shutdows (a few days every two nonth: Other interruptions of a few weeks have occurred for installation * new equipment and maincenance work.

Table 2.1. Steady-State Operating Conditfoss of GCFR-ORR Capsule GB-10

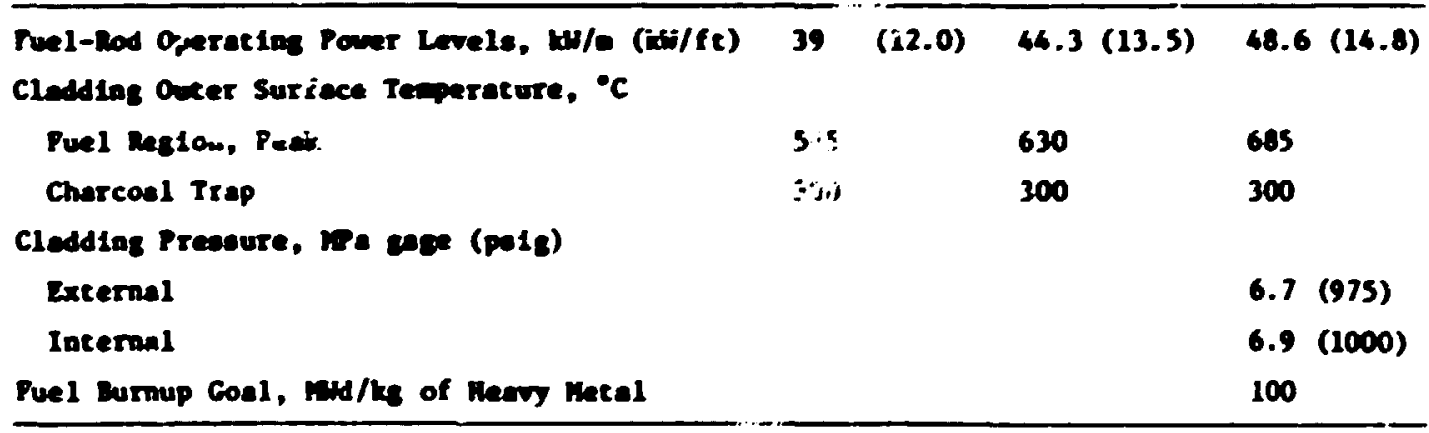




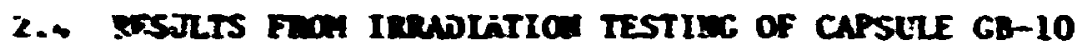

The in:fi experimental fata obcained to dace have included (1) neasureacats of the fiel-rod flow resistance as a function of fuel burmup. (2) measurcectes of steady-state fisston gas release as a function of burmap, frel-rod power level, ace inerating pressure, (3) measuremeats of fission gas release during shutdowas 3:d start-ups, (4) measuremeats of volatile fission product deposition in the $5 y=: 40$, and (5) neutron radiography of the capsule before irradiation and aiter operation at 39.4 w/m $1.2 \mathrm{kH} / \mathrm{ft})$. The results obtained during the : (rst $35 \mathrm{kud} / \mathrm{kg}$ beavy metal bornug, includine many of the ceasurements list $\rightleftharpoons$ above, hrve been reported previously. 10,12 Therefore, only the nore recent results ull be presented in the follarint sections, except were sane of the earlier resuics are added for copleteness.

During the current report period, in wich the fuel buraup advanc:d from 35 to 76 aud/kg-heavy metal, sigaificant nev information was obcained fron the fuel-rod flow resistance and ission-gas release measurements. We consider the fiou resistance data inpcrtant because it indisates that plugging an be possible in a breeder reactor fuel rod. Fission gas release data were obtained as a function of burnup and operating pressure for the radioactive gzma-emiting gases. Progress in the seasurenent of stable krypton and xenon release rates and initial operation of the tritiw monitoring system are aiso described in the following sections.

\subsubsection{Fuel-Rod Flou Resistance vs Burmup}

An Indication of fuel-rod flow resistance is ubtained whenever the sweep flow is directed through the fuel region. The two pressure elements showr in Fig - 2.3 piovide measurement of the pressure drop (LP) across the Bf irilet line and the fuel rod whenever the inlet sweep flow is changed from the nomaliy used IT line to the BF line. Flow resistance can then be estimated from the flow rate and pressure drop indications. Pressure dr'sp calculations indicate that about 21 (70 ft) of 0.69-ID (0.027-in.) BF inlet sweep line accounts for abovt $34 \mathrm{kPa}$ (4-5 psi) of the total weasured $\Delta P$ for the conditions of $6.9 \mathrm{MPa}$ gage (1000 psig) pressure and 1.0 std liter/min flow rate. Thus, ip 
meacureneats that are mel greater than $34 \mathrm{kPa}$ ( 5 psi) indicate fuelrod resistance to flow andfor possible plenging of the BF iniet sweep line. We believe the past and recent trends in the flow resistance data are due to changes in the fuel rod resistance racher than to plugsing of the Bf line.

The recent trend in the BF-TI flow resiatance at $46.3 \mathrm{kH} / \mathrm{h}$ (13.5 $\mathrm{kH} / \mathrm{ft}$ ) operation is show in Fi8. 2.7, where the reasured flow and AP data were reduced to expected flow rates at a pressure differential of $1.72 \mathrm{mPa}$ (250 psi), Q2so, and plotted agafinst irradiation tine and estinated ije: burnup. An arbitrary operacioanal linit of 1.72 hPa uas plazed on the pressure differential for fear that higher differentials might redistribute the hot fuei.

the nornaliy prefer to anke release measurements at a sweep flow rate of 1.2 std Itters/min, which gets the released gases to the

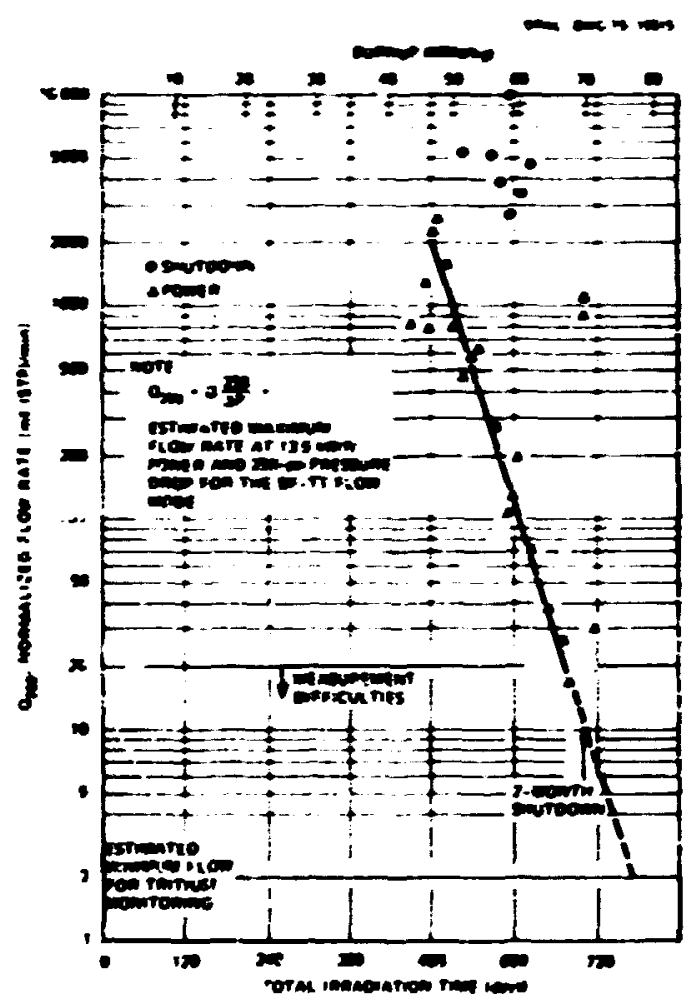

F1g. 2.7. Variation of GB-10 Flow Rates in the BF-TT Mode wIth Irradiacion Time. 
monitoring points in less than a mute. During the first half of the irradiation, this flow rate could be achieved easily. However, wth higher burnup and accumulation of fission products, an exponential decline in the normalized BF-TT flow rate occurred, as show in Fig. 2.7, until now we can flow only about $20 \mathrm{std} \mathrm{cm}^{3} / \mathrm{min}$ through the fuel rod at the $44.3 \mathrm{kH} / \mathrm{m}$ fuel-rod power level. When corrected to the ol srating pressure of $6.9 \mathrm{MPz}$ gage (1000 psig), $20 \mathrm{std} \mathrm{cm}^{3} / \mathrm{atn}$ is only about 0.3 $\mathrm{cm}^{3} / \mathrm{min}$ actual flow rate. At flow rates of $20 \mathrm{std} \mathrm{cm}^{3} / \mathrm{min}$ or below, we have measurement difficulties as well as extremely long stabilizstion and response times following a flow rate adjustment.

We have found that a shutdown or $a$ reduction in power level opens up tine BF-TT flow passages. However, upon return to power following a short shutdown, the flow resistance returns to about its previous level. When the capsule was siut down for two months (at $76 \mathrm{mWd} / \mathrm{kg}$ fuel burnup) for installation of the tritium monitoring system, we found on return to power that the flow resistance had almust disappeared, but two weeks later when we next attempted flow through the rost, the restriction had returned (see Fig. 2.7).

Although the BF-TT flow resistance at $44.3 \mathrm{~kW} / \mathrm{m}$ has increased sharply at high burnup, the flow restriction is still far from a condition that cou:d cause a complete flow blockage and fission-gas pressure buildup within a GCFR rod. The C४-10 azta do indirate a tendency for fuel rod plisging in the particular fuel-fission-product-helium sweep environment of rhe test; therefore, additisnal work in this area may be needed to ensure that plugging does not occur under GCFR conditions.

\subsubsection{Steady-State Fission-Gas Release Races Versus Burnup and Operating Pressure}

Steacy-state fission-gas release rates for the radioactive gamaemitting guses have becn measured as a function of timc at fuel-rod power levels of 39.4 and $44.3 \mathrm{kWh}(12$ and $13.5 \mathrm{kH} / \mathrm{ft}$ ) under all the planned sweep flow modes. Iurir:z the first year of operation, we routinely made sets of measurements under the TT-TT, TT-BT, TT-BB, and BF-BB flow modes (sep Fig. 2.3 and assoctated text for llow mode definitions). From these data, transport delay times through each main region 
of the rod were determined for varlous fission gas isotopes. After the first year, we started experiencing a partial blockage of the BB line and disconifinued its routine use.

Typical iractional release data (ratio of measured release rate to calculated birtil zate, $R / B$ ) obtaines during the early part of the irradiation are shown in Fig. 2.8 for the TT-TT and BF-BB flow wodes. All the release data during this time were obtained by taking gas samples, some of which were analyzed with a Ge(Li) detector, "prised points," anci the others with an NaI deter'nr, "unprined" points. With this nethod ot measurement, we obtained release data for isotopes with half-lives ranging from $3.18-\operatorname{ain}{ }^{89} \mathrm{Kr}$ to 5.27 -day ${ }^{133} \mathrm{Xe}$.

The initial release rates from the mixed-oxide fuel [Fig. 2.8(b)] were relatively high, buc they decreased, turned around, and then continued a gradual increase with burnup furing operation at $39.4 \mathrm{~kW} / \mathrm{a}$. This behaviur is believed to be assoclated with fuel temperature changes caused by fuel restructuring and by changes in the fuel-cladding gap and fuel thermal conductance. At any given time, release is extremely sensitive to temperature.

After the fission product gases are released from the solid oxidefuel matrix, their transport and venting fron the tor of the rod are controlled during stealy-state operation by their diffusion through the high-pressure hellum. Therefore, in taking the sasples under steadystate operation, the normal sampling order is to start at the top of the rod (TT-TT sweep flow mode) and work Jownward so that the inventory of fission gases below the sweeping poirit. is not upset.

The release rates for the TT-TI flow mode [Fig. 2.8(a)], or for the fission gases normally vented from the rod, show the same trends as the release rates from the mixed-oxide fuel [Fig. $2.8(\mathrm{~b})]$, and the release rate of the long-half-11fe ${ }^{133} \mathrm{Xe}$ is about the 8 ame for both flow modes, as expected. The spread as a function of haif-life 18 much greater for the vented gases, reflecting the gas-phase transport delay times.

$A$ continuation of the venting (TT-TT flow mode) and fuel release data through most of the current reporting period is shown in Fig. 2.9. At a burnup of approximately $25 \mathrm{~mW} / \mathrm{kg}$, we started using the BF-TT flow 


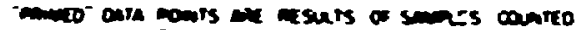

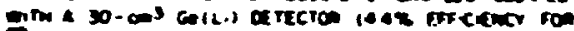

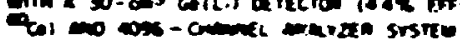

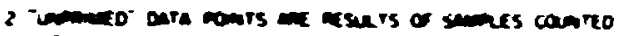

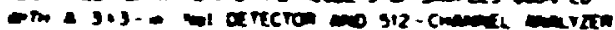

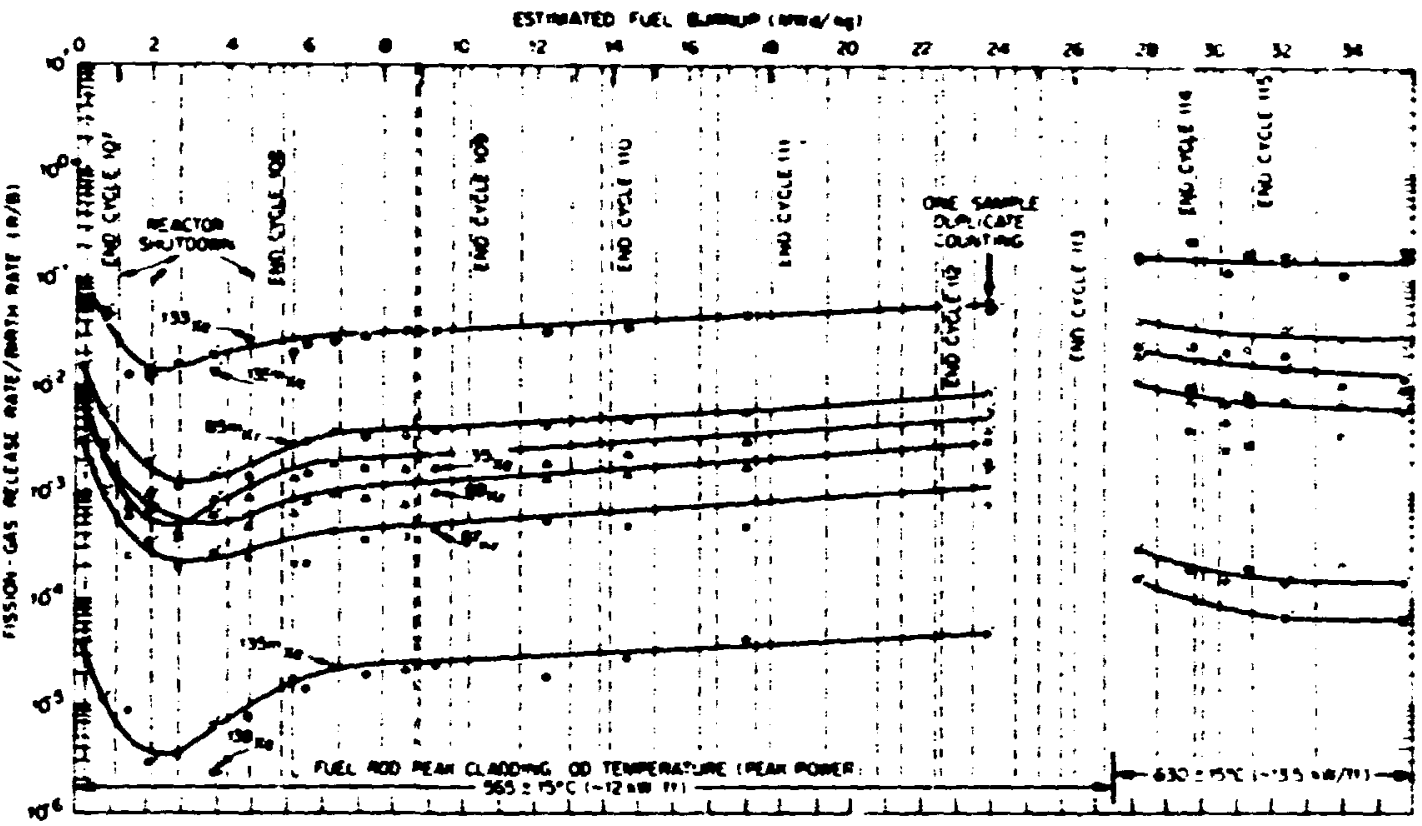

(a)

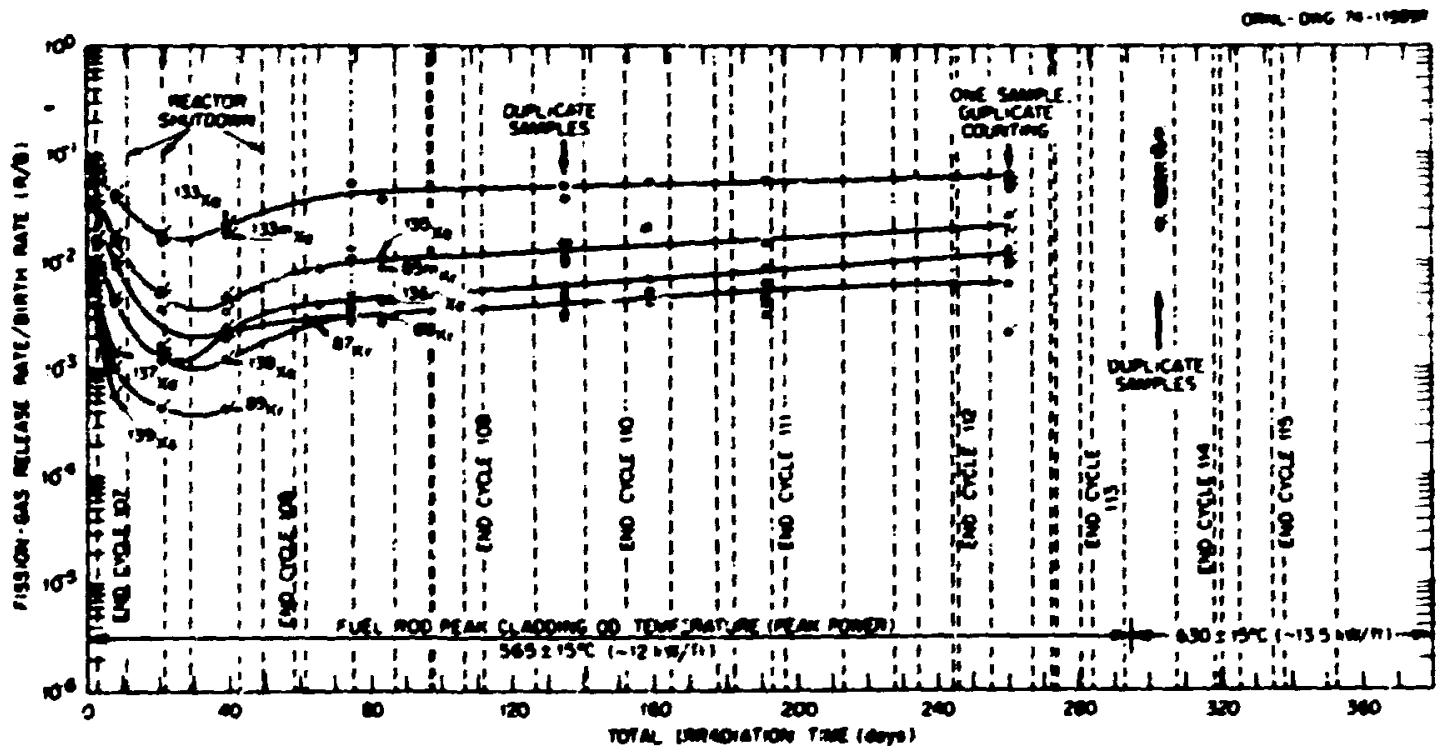

P18. 2.8. Steady-State P1ssion-Ges Release from GB-10 Puel Rod vo Tine. (a) Sweep flow sode TT-TT. (b) Hode BP-BB. 


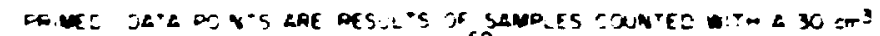

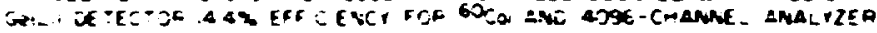
SYSTEN

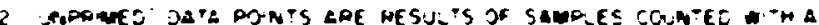

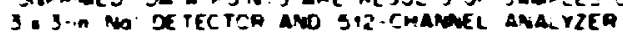

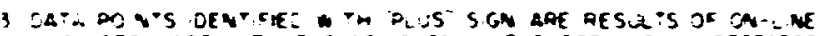

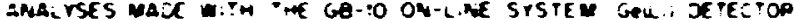

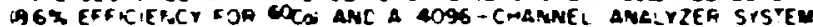

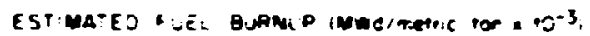

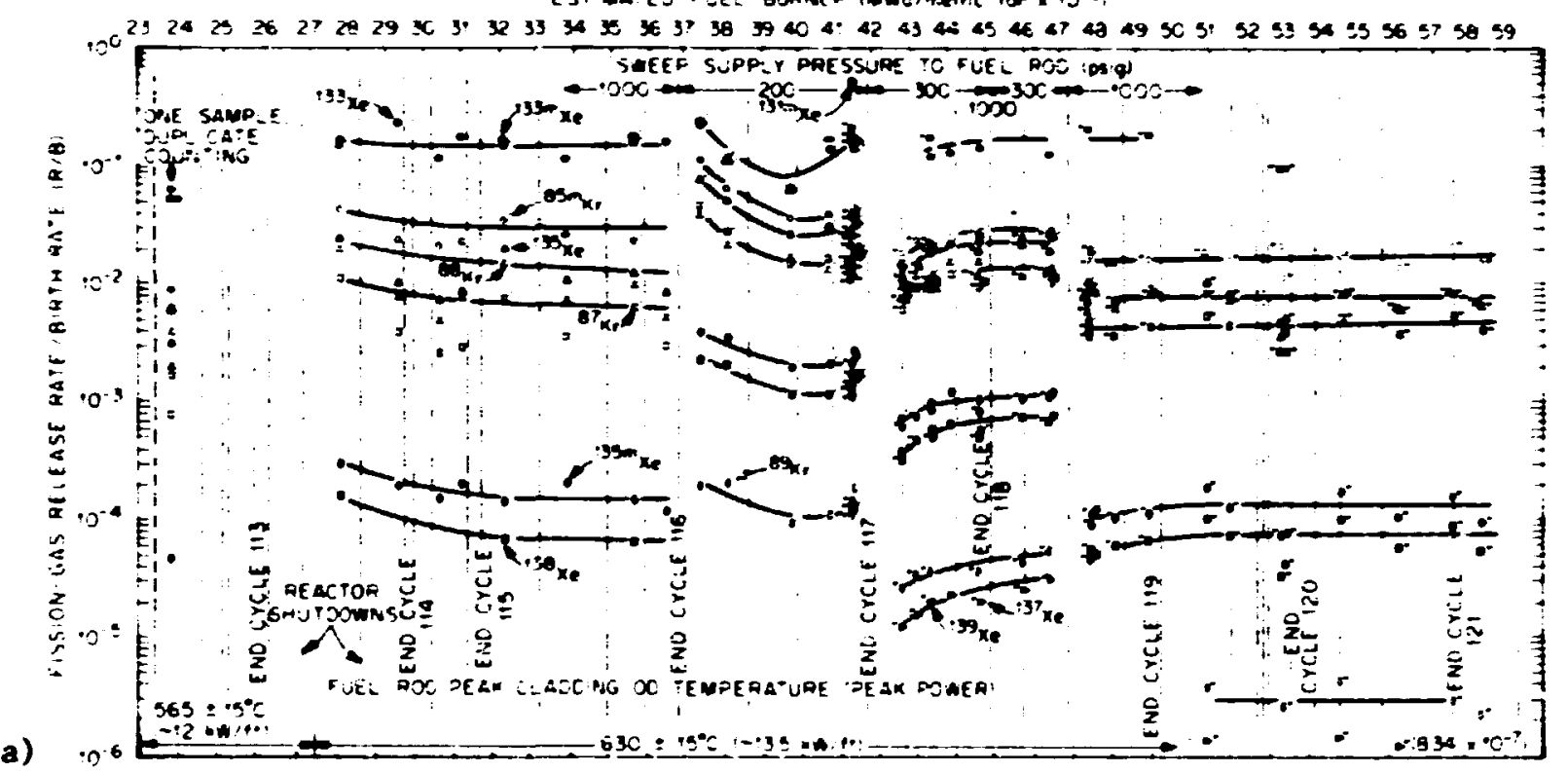

(a) $565: 15^{\circ} \mathrm{C}$

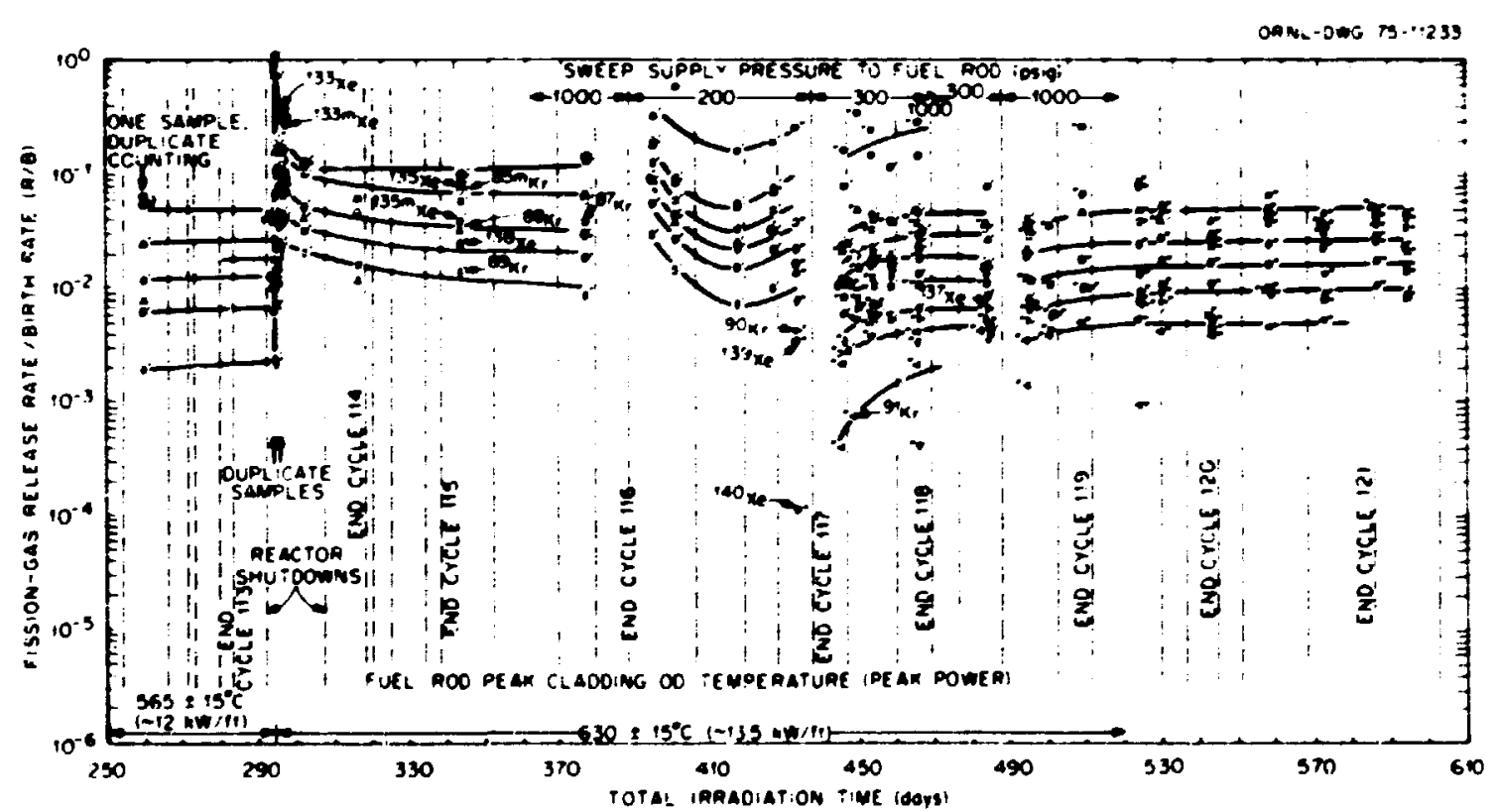

(b)

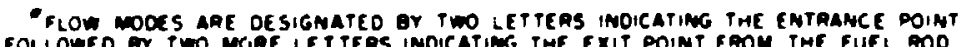

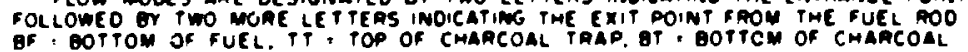

TRAP, BO : COTTON CF UPPE QL AN: ${ }^{-T}$

F18. 2.9. Steady-State P1ssion Gas Release from GB-10 Fuel Rod ve T1:2
(a) Sweep flow wode TT-TT.*
(b) Mode BR-TT. 
mode [Fig. $9(b)$ ] on a routine basis in place of the BF-BB flow mode, since a partial flow blockage of the BB line was developing. With respect to release of the fission gases, we have not seen any significant differences using any of the three fuel sweep modes, BF-BB, BF-BT, or BF-TT.

When the fuel-rod power was increased from 39.4 to $44.3 \mathrm{kH} / \mathrm{w}$, very high release rates from the fuel were observed initially [see Fig. 2.9(b)]. Apparently part of the higher iission-gas inventory in the mixed oxide fuel at the lower temperature and power level was released when the temperature and power were increased, causing the temporary excessive release fractions.

Af ter the release :ates had stabilized following the power increase tc $44.3 \mathrm{ks} / \mathrm{m}$, we started operation at reduced sweep pressure to determine the effect of operating pressure on steady-state fission-gas release. The capsule was operated at a reduced sweep pressure of $1.48 \mathrm{MPa}$ (200 psig) for two months ( $5.0 \mathrm{mHd} / \mathrm{kg}$ burnup) and then at $2.17 \mathrm{kPa}$ ( 300 psig) for the same length of time. The pressure effect on release frow the fuel [Fig. 2.9(b)] was greater than expected. Apparently helium pressure affects release from the fuel, and after each large change in the pressure level the new equilibrium takes a long time to establish. After return to $7.0 \mathrm{MPa}(1000 \mathrm{psig})$ the release rates returned to a level consistent with that before the reduced pressure operation.

The GB-10 on-line $\mathrm{Ge}(\mathrm{Li})$ detector system was placed in operation in March 1974, when the estimated fuel burnup was about 41 wd/kg. Data points obtained with the on-line system are identified with a "p'us" sign in Fig. 2.9. Using the on-line system eliminates sample handing and lets us measure isotopes with shorter half-lives than is possible by the gas sampling method. From some spectra, we determined release rates of $10-\mathrm{sec}{ }^{91} \mathrm{Kr}$ and $16-\mathrm{sec}{ }^{140} \mathrm{Xe}$ [see Fig. 2.9(b)]. Also, the measurements are much easier with the on-1ine system. Although not apparent in the figures, gas samples containing less than $0.01 \mathrm{std} \mathrm{cm}^{3}$ of the BF-TT gas typically read $1 \mathrm{R} / \mathrm{hr}$ or wure on contact. 
The release rates for the $\Pi-\Pi T$ flow mode, or venting rates, during the reduced-pressure operation [Fig. 2.9(a)] showed the same release patterns as the fuel release rates showed and also the expected ef fect of pressure on gas-phase transport, the ef fect being greater the shorter the half-life of the isotope. For example, the vellting rates of 15.6-ain ${ }^{1350} \mathrm{Xe}$ and $17^{-\mathrm{min}}{ }^{130} \mathrm{Xe}$ were we than a factor of 10 higher at $1.48 \mathrm{MPa}$ (200 psig) than at $7.0 \mathrm{MPa}(1000 \mathrm{psig})$. These data show clearly how the high operating pressure suppresses steady-state venting of the fissicn gases. In fact, we had originally planned to go to $0.79 \mathrm{kPa}$ (100 psig) following the $1.48 \mathrm{MPz}$ (2.0 psig) operation, but we decided to obtain the release data at the intermediate pressure of $2.17 \mathrm{MPa}$ (300 psig) instead because of the high activity release at low pressure.

In all the $G B-10$ fractional release $(R / B)$ data reported to date, we have calculated the isotopic birth rates $(B)$ on the basis of the initial loading of fissile atoms. Initially the principal fissile isotopes were ${ }^{239} \mathrm{Pu}$ and ${ }^{235} \mathrm{U}$. We have assumer in the birth rate calculations that no change has occurred in the fraction of fissions due to ${ }^{239} \mathrm{Pu}$ and ${ }^{235} \mathrm{U}$ from their initial values of 0.664 and 0.336 , respectively, and we have not taken into account buildup of ${ }^{241} \mathrm{Pu}$. These assumptions : e important since the yields per fission from ${ }^{239} \mathrm{Pu},{ }^{241} \mathrm{Pu}$, and ${ }^{235} \mathrm{U}$ are not the same for many of the fission-product isotopes. The total fission rate used in the birth rate calculations is based on the fuelrod linear power distribution at the time of the release rate $(R)$ measurement, which in turn is estimated from temperature indications with r.eat transfer equations.

A recent burnup calculation for $\mathrm{GB}-10$ was made to determine nuclide concertrations with time and neutron flux requirements for maintaining the desired fuel-rod power levels during the remainder of the irradiation. From those results, relative fission rates for ${ }^{239} \mathrm{Pu},{ }^{241} \mathrm{Pu}$, and ${ }^{235} \mathrm{U}$ were estimated at several different irradiation times to determine the magnitude of error involved in the present $\mathrm{GB}-10$ birth rate calculations, where changes in the relative fission rates are neglected. The results of these calculations are given in Table 2.2. The 0.664 and 0.336 being used for the fractions of fissions due to ${ }^{239} \mathrm{Pu}$ and ${ }^{235} \mathrm{U}$ in the birth 
Table 2.2. Calculated Isotopic Fission Rate Distributions in Capsule GB-10

\begin{tabular}{|c|c|c|c|}
\hline \multirow{2}{*}{$\begin{array}{l}\text { Accumulated } \\
\text { Irradiation } \\
\text { Tine } \\
\text { (days) }\end{array}$} & \multicolumn{3}{|c|}{ Relative Isotopic Fission Rates } \\
\hline & $23^{9} \mathrm{Pu}$ & ${ }^{24} \mathrm{Pu}$ & $235 \mathrm{U}$ \\
\hline $\mathbf{0}$ & 0.668 & $\mathbf{0}$ & 0.332 \\
\hline 600 & 0.555 & 0.046 & 0.399 \\
\hline 879 & 0.436 & 0.152 & 0.412 \\
\hline
\end{tabular}

rate calculations are close to the values on day 0 in Table 2.2. However, as the fuel burnup reaches high levels the relative isotopic fission rates change appreciably and should be taken into account in the calculations. We decided not to make this correction to the $R / B$ data at this time, since we plan to make a review of a!l fossible exrcrs before the $R / B$ data are reported in final form.

\subsubsection{Stable Noble Gas Release Measurements at $13.5 \mathrm{~kW} / \mathrm{ft}$}

The sampling system (Fig. 2.5) ior taking large gas samples ( 1 liter) for the determination of stable nuble-gas release rates using mass spectrometry was placed in operation in June 1974. Subsequently, five samples were taken at about two-month intervals between samples. Preliminary release rate to birth rate $(R / B)$ results for the five samples are given in Table 2.3. Some of the krypton results are close to that expected - that is, greater than $30 \%$ fractional release - but the xenon results are all too low by almost a factor of 10 . Therefore, it is likely that most of these first data will be discarded lat.er when the samplir.s and analysis techniques are perfected.

After the $R / B$ results were calculated for the first sample, we began examining the special techniques being used to analyze the samples. In preparing the samples for analysis by mass spectrometry, the sample gas is spiked with ${ }^{30} \mathrm{Ar}$ and then cencentrated to bring the krypton and xenon isotopes up to measurabie levels. Several steps in the sample cransfer and preparation process were varied in an attempt to locate a 
Table 2.3. Prelininary Results of GB-10 Stable Noble Gas Release Measurements at $44.3 \mathrm{~kW} / \mathrm{m}(13.5 \mathrm{~kW} / \mathrm{ft})$

\begin{tabular}{|c|c|c|c|c|c|c|c|c|c|}
\hline \multirow{2}{*}{ Date } & \multirow{2}{*}{$\begin{array}{l}\text { Sweep } \\
\text { Flow } \\
\text { Hode }\end{array}$} & \multicolumn{8}{|c|}{ Datio of Fission-Gas Delease Date to Birth Rate, $Z$} \\
\hline & & ${ }^{-3} \mathbf{x}$ & $\bullet 4 \mathbf{x}$ & 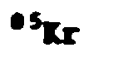 & $\bullet_{\mathbf{r} \mathbf{r}}$ & ${ }^{131} \mathrm{Xe}$ & ${ }^{232} \mathrm{ze}$ & $134 x e$ & $136 x$ \\
\hline $7-1-74$ & $\pi-\pi$ & 8.34 & 11.0 & 8.89 & 10.3 & 1.56 & 1.67 & 1.38 & 2.52 \\
\hline $10-1-74$ & BF-TT & 33.2 & 51.3 & 61.3 & 42.4 & 3.07 & 3.52 & 3.39 & 6.11 \\
\hline $11-21-74$ & $\mathbf{B F}-\mathbf{T T}$ & 23.2 & 23.8 & 21.8 & 21.8 & 4.14 & 4.52 & 6.81 & 8.64 \\
\hline $1-28-75$ & $T I-\pi T$ & 14.2 & 15.0 & 14.0 & 14.6 & 0.99 & 1.06 & 1.01 & 1.91 \\
\hline $3-25-75$ & $T I-I I$ & 24.6 & 25.9 & 23.4 & 25.0 & 2.94 & 3.23 & 3.00 & 5.53 \\
\hline
\end{tabular}

problea, but as seen in Table 2.3 these efforts did not significantly improve the results. Next we took a hard look at the way we were taking the samples. After trapping a sample of the GB-10 effluent gas in the shielded 2-liter vessel inside the valve box and waiting six weeks for decay of the radioactive gases, we were evacuating the lines and then slowly opening a valve to allow the gas to pass through about $3 \mathrm{~m}$ (10 ft) of 3.2-m-OD (1/B-i1.) line to an evacuated 2-1iter sampie vessel outside the valve box (see Fig. 2.5). When the pressure in the two vesse is had equalized, we closed the valves and removed the sample vessel. Following discussions with others, we now believe we may have been fractionating the gas mixture by this method of sampling, tending to leave the heavier isotopes, especfally the xenons, in the first vessel.

After the results were obtained for the fifth sample, we decided to discontinue sampling until the sampling system could be modified. We are currently modifying the system to permit circulation and mixing of the gases in the two vessels before the sample vessel is isolated and removed.

\subsubsection{Intitial Operation of the GB-10 Tritium Monitoring System}

Funding for the GB-10 tritium monftoring system was provided in late November 1974. By the middle of June 1975, the complex system had been designed, fabricated, performance-checked, installed, and trial-run operated with clean hellum. A "zero base-line" reading was obtained on 
the ion ctamber (see Fig. 2.6) under heilum flow before any tritiu was introduced into the system. This reading, $C .45 \mathrm{mV}$, was abcut the same as that in the laboratory performance tests before installation at the reactor.

Two more tritium monitoring system runs were made during the current report period. Both these runs were systee calibration checks using the lowest concentration tritium-in-helium calibration gas $\left(5 \times 10^{-5} \mu \mathrm{Ci} / \mathrm{cm}^{3} \mathrm{STP}\right)$. Tine results were encouraging in that both the response of the calibrated ion chamber [about $54 \mathrm{mV}$ at $70 \mathrm{kPa} g a g e$ (10 psig) operating pressure] and the results for tritiun collected in :TO trap samples indicated the tritium concentration in the gas stream to be reasonably close to the known concentration in ie supply cylinder. Also, we were able to clean up the system in about $3 \mathrm{hr}$ to an ion chamber reading within a factor of 2 of the "zero base-line" value (i.e., to a base-line readjng below $1 \mathrm{mV}$ ).

At this point it appears that the eritium monitoring system is operating as designed and that its sensitivity for measuring tritiun in the capsule gas will be satisfactory.

\subsection{PLANS FOR REMAINDER OF CAPSULE GB-10 UPERATION}

We plan to continue the routine acquisition of experimental data at the present $44.3 \mathrm{~kW} / \mathrm{m}(13.5 \mathrm{kH} / \mathrm{ft})$ fuel-rod power level and at the $f$ inal power level of $48.6 \mathrm{kH} . \mathrm{m}(14.8 \mathrm{kH} / \mathrm{ft})$. In addition, speciaj. experiments are planned. First priority in the next few weeks wi $i l$ be io conduct several tritium monituring experiments at the present power level of $44.3 \mathrm{kH}$ 'm to obtain an early first set of measurements of the tritium content to be expected in the GB-10 effluent sweep gas and to determine the operating characteristics of the system under these conditions. The results of these experiments will provide the information neaded for planning alditional experiments and perhaps will indicate to some degree the effort and number of experiments that will be required to obtain the desixed tritium release and transport information. Since GB-10 has only one year cf or,eration left, it is important to get this work started as soon as possible. Also of high priority is completion of the calibration and installation of the instrumentation for measuring the $\mathrm{H}_{2}$ and $\mathrm{H}_{2} \mathrm{O}$ impurity levels in the sweep gas. 
After the initial tritium experiments are completed, we plas to obtain iodine deposition measurements during a shutdown period and thea increase the fuel rod power to $48.6 \mathrm{~kW} / \mathrm{m}$ for most of the rewainder of the irradiation. After a period of operation at $48.6 \mathrm{~kW} / \mathrm{m}$ is achieved, several special tests will be conducted. Near the end of the irradiation, we plan to conduct power cycling tests between 44.3 and 30 to $40 \mathrm{kw} / \mathrm{m}$ (13.5 and 9-12 kW/ft) to obtain release data and determine the numbers of cycles to reach equilibrium release conditions. In another special test we plan to measure the release spectrum as a function of sweep flow rate over a wide flow rate range. This test similates leak rates in a GCFR fuel rod and will provide data that can be used in the design of instrumentation for locating leaking GCFR fuel elements. Some pressure cycling tests may also be conducted.

Neutron radiography of the GB-10 capsule following operation at 44.3 and $48.6 \mathrm{kH} / \mathrm{m}$ will not be possible. The ORR radiograpiny $\mathrm{rig}$, which was used to obtain the preirradiation and $39.4 \mathrm{kH} / \mathrm{m}$ neutron radiographs developed a le:k and had to be removed. Replacement with a new rig is uncertain at this time.

\subsection{REFERENCES}

1. R. J. Campana, "Pressure Equalization Systan for Gas-Cooled Fast Breeder Reactor Fuel Elements," itus2. Technol. 12: 185-93 (October 1971).

2. A. H. Longest, J. A. Conlin, C. H. Cunniugham, R.. R. Thoms, E. D. Clemer, and L. P. Pugh, "Irradiation of GCFBR-ORR Capsule GB-9," Gas-Cooled Reactor ard Thoriun Utilization Programs Annu. Progr. Rep. Sept. 30, 1971, ORNL-4760, pp. $149-63$.

3. A. W. Longest, J. A. Conlin, C. W. Cunningham, K. R. Thoms, and E. D. Clemer, "Irradiation of GCFR-ORR Capsule GB-9," Gas-Cooled Reactor Progroms Annu. Progr. Rep. Dec. 31, 1972, ORNL-4911, pp. 213-15.

4. A. W. Longest et al., "Fission-Gas Release Measurements fror. Fast Breeder (U,Pu) $\mathrm{O}_{2}$ Fuel," Trans. Am. Nucl. Soc. 13: 604 (1970). 
5. A. W. Longest, R. B. Fitts, and J. A. Conlin, "Fission Gas Release Behavior in a Vented (U,Pu) $\mathrm{O}_{2}$ GCFBR Fuel Pin," Trans. Am. Nucl. Soc. 15: $197-98$ (1972).

G. R. B. Fitts and E. L. Long, Jr., "Postirradiation Exanination of GCFR-ORR Capsuie GB-9," Gas-Cuoled Reactor Programs Annu. Progr. Rep. Dec. 31, 1972, ORNL-4911, pp. 215-20.

7. S. Langer et al., "Volatile Fission Product Migration and Plateout in GCFR Rod Irradiations," Trans. Am. Mucl. Soc. 15: 850 (1972).

8. R. J. Campana et al., "The Effect of Irradiation Results on the GCFR Pressure Equalization Systex (Venting) Design," Trans. Am. NucZ. Soc. 16: 109 (1973).

9. J. R. Lindgren et al., Imadiation Testing in the Development of Gas-Cooled Fast Breeder Fuel Elements, GA-A-12657 (1973).

10. A. W. Longest and J. A. Conlin, "Design and Operation of GCFR-OKR Capsule GB-10," Gas-Cooled Reactor Programs Annu. Progr. Rep. Dec. 31, 1972, ORNL-4911, Pp. 220-33.

11. J. R. Lindgren et al., Planned Thermal Irradiaticn of ManifoldVented (U,Pu) O2-Fueled Rod ir ORR Capsule GB-10, GA-A-12123 (1973).

12. A. W. Longest and J. A. Conlin, "Results from Irradiation Testing of Capsule GB-10," Gas-Cooled Reactor. Progroms Annu. Frogr. Rep. Dec. 31, 1973, ORNL-4975, Pp. 298-304.

13. S. Langer, G. Buzzel11, and P. W. Flynn, Postimadiution Excomination of Charcocl Trap in irradiation Copsule CB-9, GA-A-13298 (1975). 


\title{
3. CCF \& CORE FLON TEST LOOP
}

\author{
A. G. Grindell
}

\subsection{Irtroduction - A. G. Grintell}

\subsubsection{Objectives}

The viability of the Gaz-:ooled Fast Breeier Reactor (GCFR) depends strongly upon the steady-state characteristics and the transient responses of the core elements. Infonwtion on heat transfer and pressure drop characteristics of the GCFR vise during steady-state operation is important to the design and cojts of the GCFR. Information on the responses of the core to normal, upset, emergency, and accident transients anticipited for the GCFR is fmo-tant to determining the destgn a-t safety argins of the core.

The Core Flow Test hyop (CFTL), which is part of the GCER Program at ORL, will be designea' - o provide this information. It is a highpressure, high-cemperati ir, out-of-reactor, circulating hellum system that w11l provide the sleidy-state requirements of power, heat removal, and coolant helfun flow rate, pressure, and tesperature; the power and coolant heliw requil ants te simulate anticipated transients for GCFR core elements; and th:n rapid helium depressurization to simulate the GCFR design basis ar :ident. In addition, the loop will provide for testing mockups of in-ceactor test configurations as required.

In the CFIL, : ull-size blanket elements and segnents of fuel and control rod elewer ts for the GCFR core, which will be simulated with electric heaters referred to as fuel pin simulators (FPS), maintained in a spectffed arrangement in a test bundle, will be subjected to steadyrtate dngign operating conditions and to normal, upset, emergency, and accident transients. Heat transfer and pressure drop characteristics will be measured. Theragl and mechanical interactions between the FPSs and the grid spacers and hexagonal duct, caused principally by the transient operations and core undercooling, will be determined with both visual observation and interim and post-test measurements. 
Steady-state operation of test bundles in the CFTL, which will include flat power distribution across test bundles at any pouer leve: from 100 to $5 \pi$ of desfign and skewed poser distribution with slope variable from 0.2 to 0.47 per radial millineter $\left(5-107 / 1 n_{\text {. }}\right)$ across the bundle, will be conducted to:

1. verify heat transfer and fluid-flow data obtained frce other experimental prograns;

2. verify analytical wethods of extrapolating heat transfer and fluidflow data to full-size core elements;

3. examine the rod bowing caused by thermal gradients across test bundles;

4. obtain vibrational data;

5. explore local fliw blockage to detect blockage, to measure thermal and hydraulic effects of blockage, and to verify analytical wodels used to calculate effects of blockage;

6. assist the design of in-reactor test bundles and provide comparison between in-reactor and out-of-reactor bundles, as required.

Transient operation of the CFTL will include prescribed variations with time in (1) test bundle coolant helium flow rate; and (2) power from an inftial flat or skewed power distribution to simulate normal, upset, and accident transients; and (3) helfum pressure to simulate the design basis depressurization accident. Such operation will be conducted to:

1. verify the ability of GCFR core elements to withstand ths transients;

2. deterulne design and safety margins of the core elements to extreme undercooling, overcooling, and depressurization transients;

3. explore the operation of core elements for structure-related behavior and deficiencies;

4. obtain ancilliary informalion on the interaction betwein fuel rod and onacer grid and vibration and performance data on the out let gas temperature sensors, the low control orffices, and the control rods.

\subsubsection{Test Capability}

The CFTL will provide a total of $4100 \mathrm{kH}$ of electric power to the test bundle FPSs in discrete control zones. Each zone will correspond to a row of simulators, and each row is parallel to a selected 
flat face in the hexagonal test bundle configuration. In a flat pover distribution an identical anount of electric power will be suppled to each simulator ir. a test bundle. In a skewed power distribution, although the same value of power is supplied to each sfanlator in a single zone, the values of total power in the several zones are varied systemefcaliy to provide a relatively smooth linear power distribution across the test bundle from a aximue at one hexagonal face to a minimum at the opposite hexagonal face. During a power transient simulating a reactor scran, the test bundle power will be reduced from 100 to 107 in 1, 2, 4, or $16 \mathrm{sec}$. Figure 3.1 indicates a $1-\sec$ transient of GCFR core poser during a reactor trip.

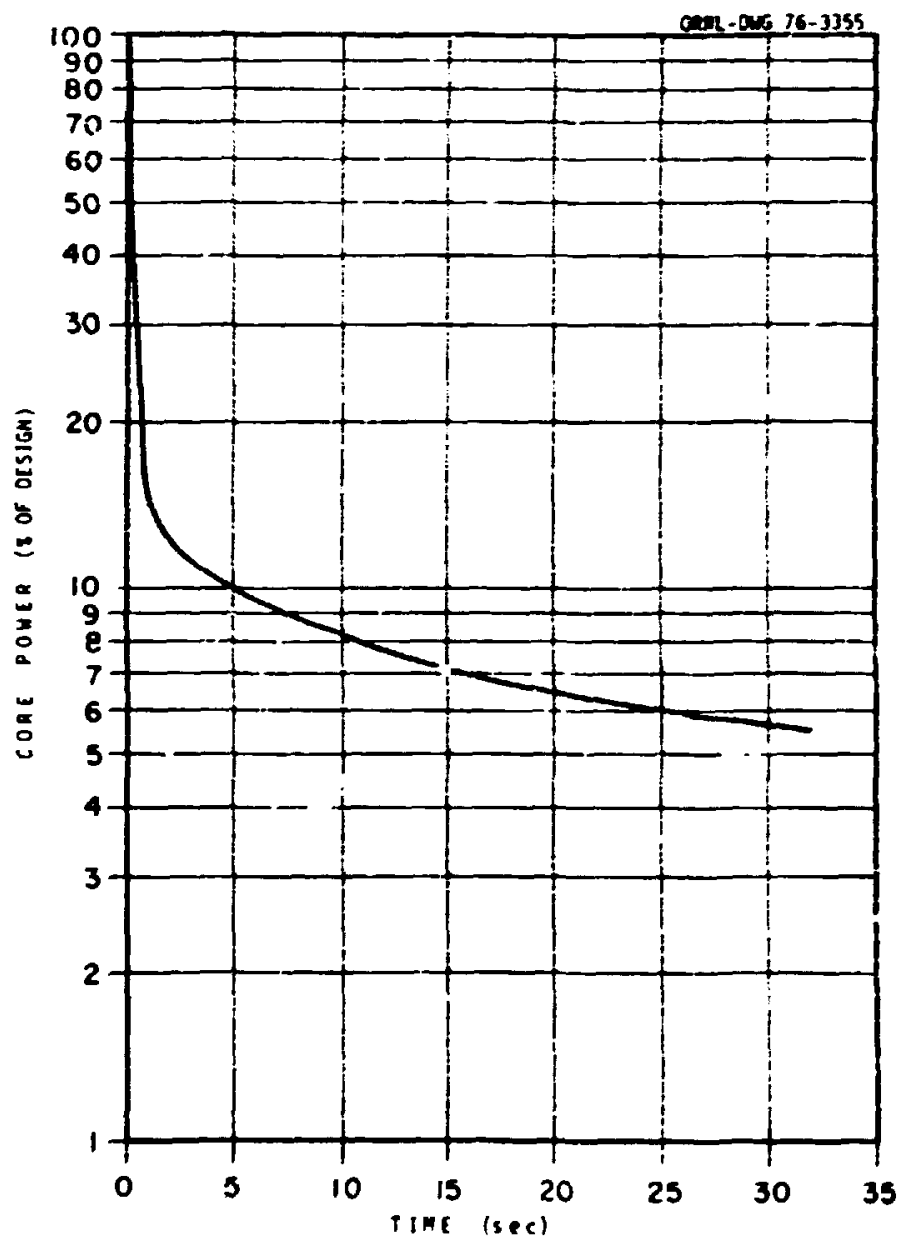

Fig. 3.1. Core Power versus Time Durf.118 a GCFR Reactor Trtp. Gravity drop of primary rods. 
The CFIL will provide coolant reliue to the test bundle at 8.62 to $10.34 \mathrm{IPa}(1250-1500 \mathrm{psia})$ inlet pressure and 260 to $33^{\circ} \mathrm{C}\left(500-650^{\circ} \mathrm{F}\right)$ inlet cemperature at ass flow rates up to $2.76 \mathrm{~kg} / \mathrm{sec}(6.1 \mathrm{lb} / \mathrm{sec})$, which is sufficient to rewove heat iron a 91-heater test bundle. During a flow transient, the coolant he!lu flow rate will be reduced fron 100 to 102 in tibe periods of $1,2,4$, or 16 sec. Figure 3.2 shous a typical coolant heliu flow transient during a GCFR reactor scran.

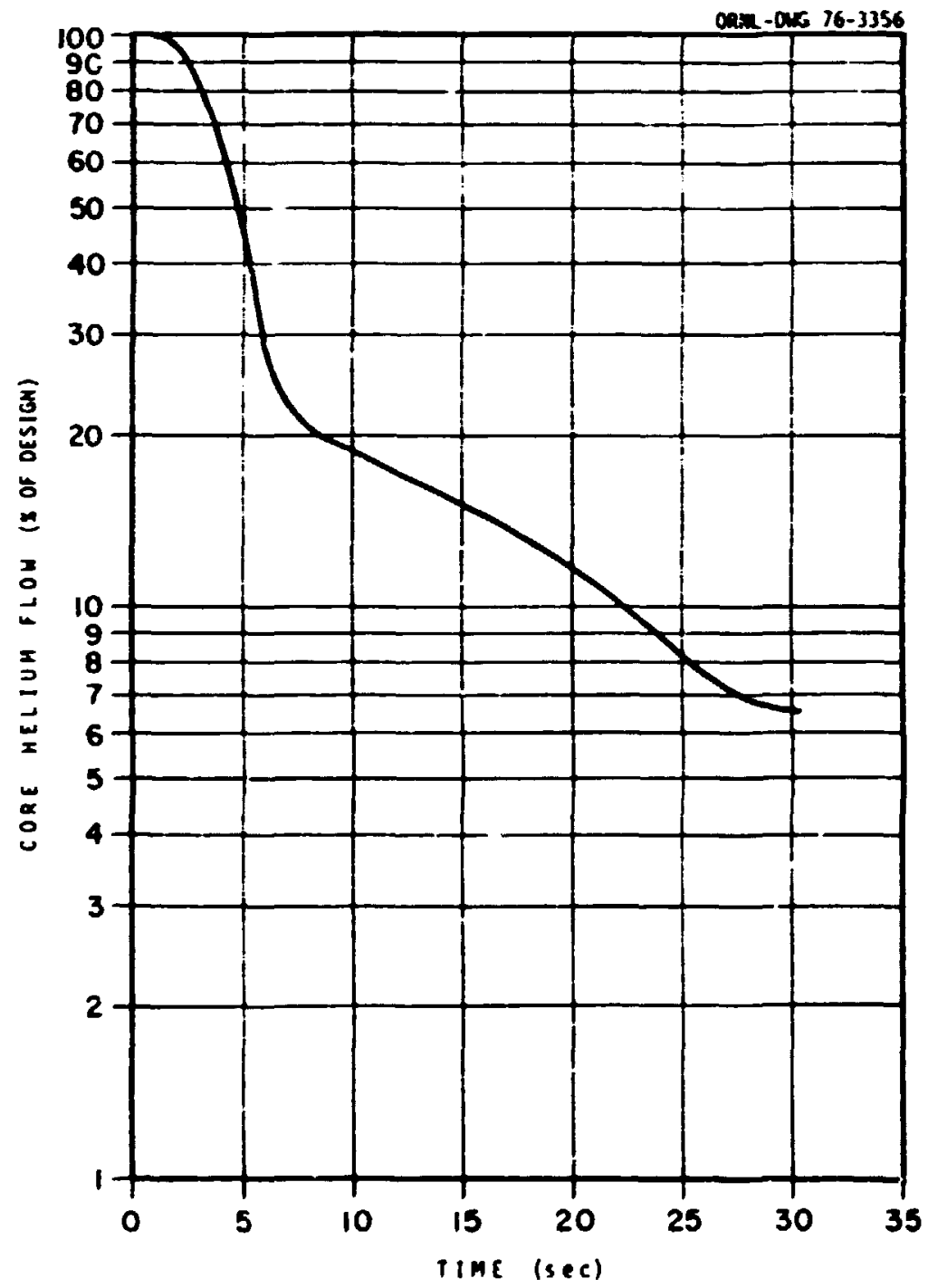

Fig. 3.2. Hlow Rate of Core Coolant Helium versus Time During a GCFR Reactor Trip. 
The CFTL will provide depressurization of the coolant heliue from 10.34 to $0.15 \mathrm{MPa}(100$ to $1.5 \mathrm{ata})$ absolute during tive periods of 1 , 2 , 4, or 8 nin. Figure 3.3 shows the calculated hellun pressure during a 4-nin depressurization as anticipated for tie GCFR.

The CFIL. will also pernt operating a specifically designed test bundle in an approach to welting the FPS cladding. The CFTL will be equipped with a fast scan data acquisition systen (FSDAS) to record real tive data on mpetic tape during both fast transient and steady-state operations. We plan a high-speed 640-channel systea able to take 20,000 sasples of data per secoad. Table 3.1 presents additional steady-state operating requirements for th.e CrM.

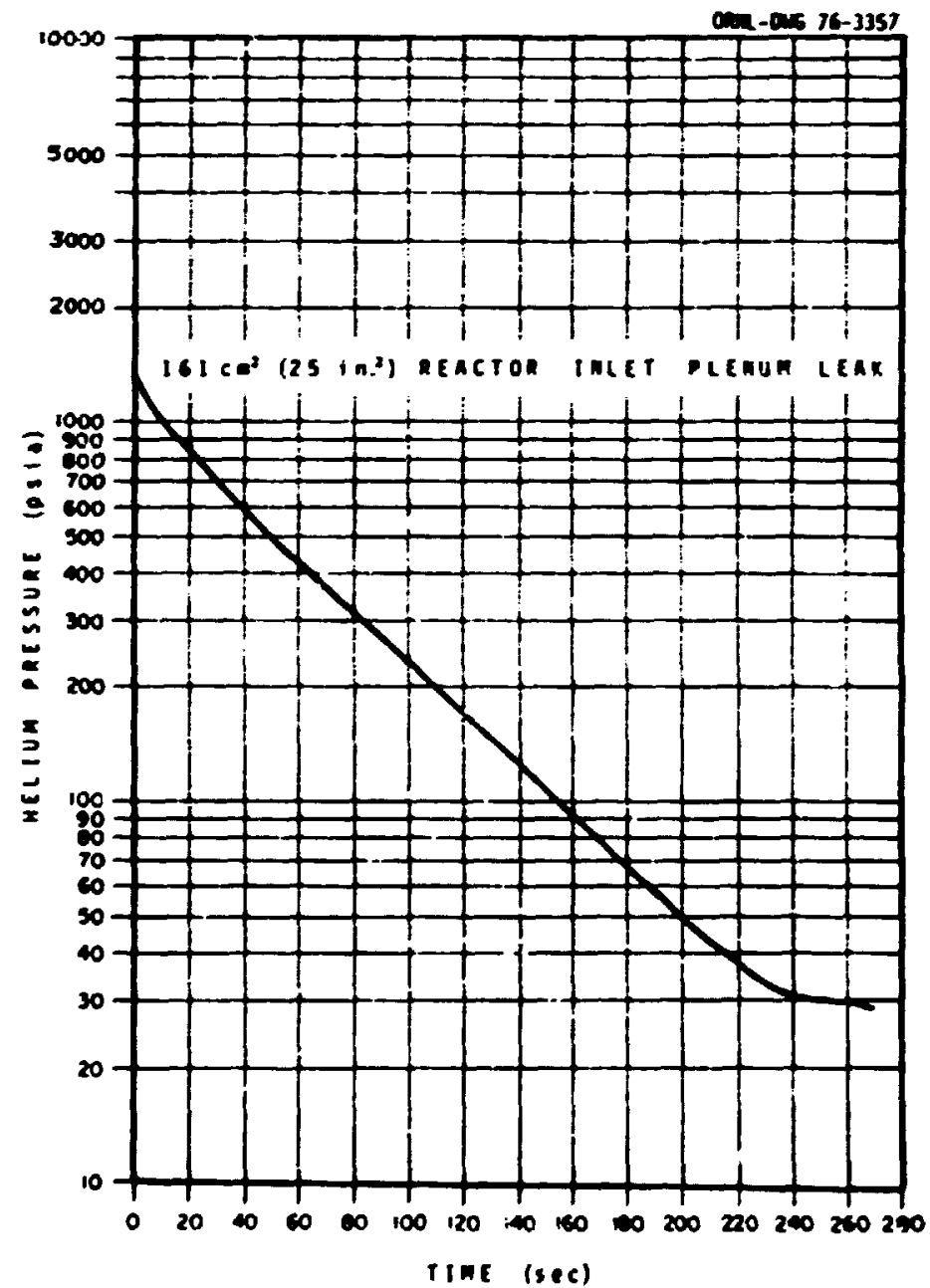

P1g. 3.3. Coolant Helfun Pressure versus TIL During a GCPR Design Basis Accident Depressurization. A pressure of 1 LPa corresponds to $145 \mathrm{ps} 1$. 
Tabie 3.1. Steady-State Operating Requirements in the CFTL

\begin{tabular}{|c|c|}
\hline Coolant & Heliun \\
\hline \multicolumn{2}{|l|}{ Pressure, MPa (psia) } \\
\hline Loop aximan & $10.34(1500)$ \\
\hline GCFR & $9.03(1310)$ \\
\hline \multicolumn{2}{|l|}{ Test section } \\
\hline$A P / P$ & 0.034 \\
\hline \multicolumn{2}{|l|}{ Inlet temperature, ${ }^{\circ} \mathrm{C}\left({ }^{\bullet} \mathrm{F}\right)$} \\
\hline Noninal & $321(610)$ \\
\hline Minimu & $260(500)$ \\
\hline Maximum & $343(650)$ \\
\hline \multicolumn{2}{|l|}{ Outlet tesperature, ${ }^{\circ} \mathrm{C}\left({ }^{\bullet} \mathrm{F}\right)$} \\
\hline Noninal & $549(1020)$ \\
\hline Miniman & $260(500)$ \\
\hline Maximus & $593(1100)$ \\
\hline \multicolumn{2}{|l|}{ Heliun flow per rod $g / \sec (1 b / h r)$} \\
\hline Core maximan & $30.5(242)$ \\
\hline Blanket maxinum & $4.4(35)$ \\
\hline Core maximum linear power rating, $\mathrm{kH} / \mathrm{m}(\mathrm{kH} / \mathrm{ft})$ & $54.1(16.5)$ \\
\hline Axial maximu-to-average power ratio & 1.21 \\
\hline Maximu radial fuel power gradient, $z / m(z / 1 n)$. & $0.4(10)$ \\
\hline Miniaue radial power gradient & 0 \\
\hline Total simulated fuel rod lergth, = (in.) & $2.28(90)$ \\
\hline Simulated core length, (1n.) & $0.99(39.2)$ \\
\hline Axial blanket length (each end), m (in.) & $0.46(18)$ \\
\hline Similated radial blanket rod length, w (in.) & $2.28(90)$ \\
\hline Maximum power per fuel rod, kH & 45 \\
\hline Nodinal power per fuel rod, $\mathrm{kH}$ & 36 \\
\hline Power per blanket rod, $\mathrm{kH}$ & 11 \\
\hline
\end{tabular}




\subsubsection{Sungry of Progress}

\subsubsection{Conceptual Design}

The coaceptual design of the CFT, which uas completed early in FY 1975, and is indicated in the flou diagran, Fig. 3.4, was sumarized in an OBul internal cenrandun, "Conceptual Design Report for the Core Flow Test Facility." The Construction Project Data Sheet, orfiginally 76-0Rn-1 but now 77-HRI-16, wich presents the cost estimate, was completed also early in FY 1975. The dynamic simulation ef fort and layout work to support the conceptual design are reported in subsequent sections of this chapter.

\subsubsection{Documentation}

The Management Plan for the CFTL was subnitced to the AEC in october 1974. The AEC concurred with our codes and standards proposal for the construction of the pressure retaining boundaries of the CFTL, which also was subd:ted to the AEC early in FY 1975. Eriergy Research and Development Adainistration (successor to AEC) has indicated agreement with our quality assurance plans, which vere subaitced in February 1975.

Section 1, Functions and Design Requirements, and Section 2, Design Description, of the CFTL Systen Design Description were subatted to ERDA and distributed as required.

Cost estimates prepared to ronstruct the CFTL to capacities of either 61 or 92 FPSs, with expense or capital funding and for various construction starting dates, were furnished to RRD.

\subsubsection{Derelopment}

The conceptual design indicated that developwent effort was needed for the hellu circulators, test bundle stimulators of the GCFR fuel and blanket pins, electrical power supply and control for the test bundle heaters, and the elinination or satisfactory reduction of electroangnetic nolse on the ceaperature signals from the heater therwocouples. Reports on each of these efforts are presented in subsequent sections of this chaper. 

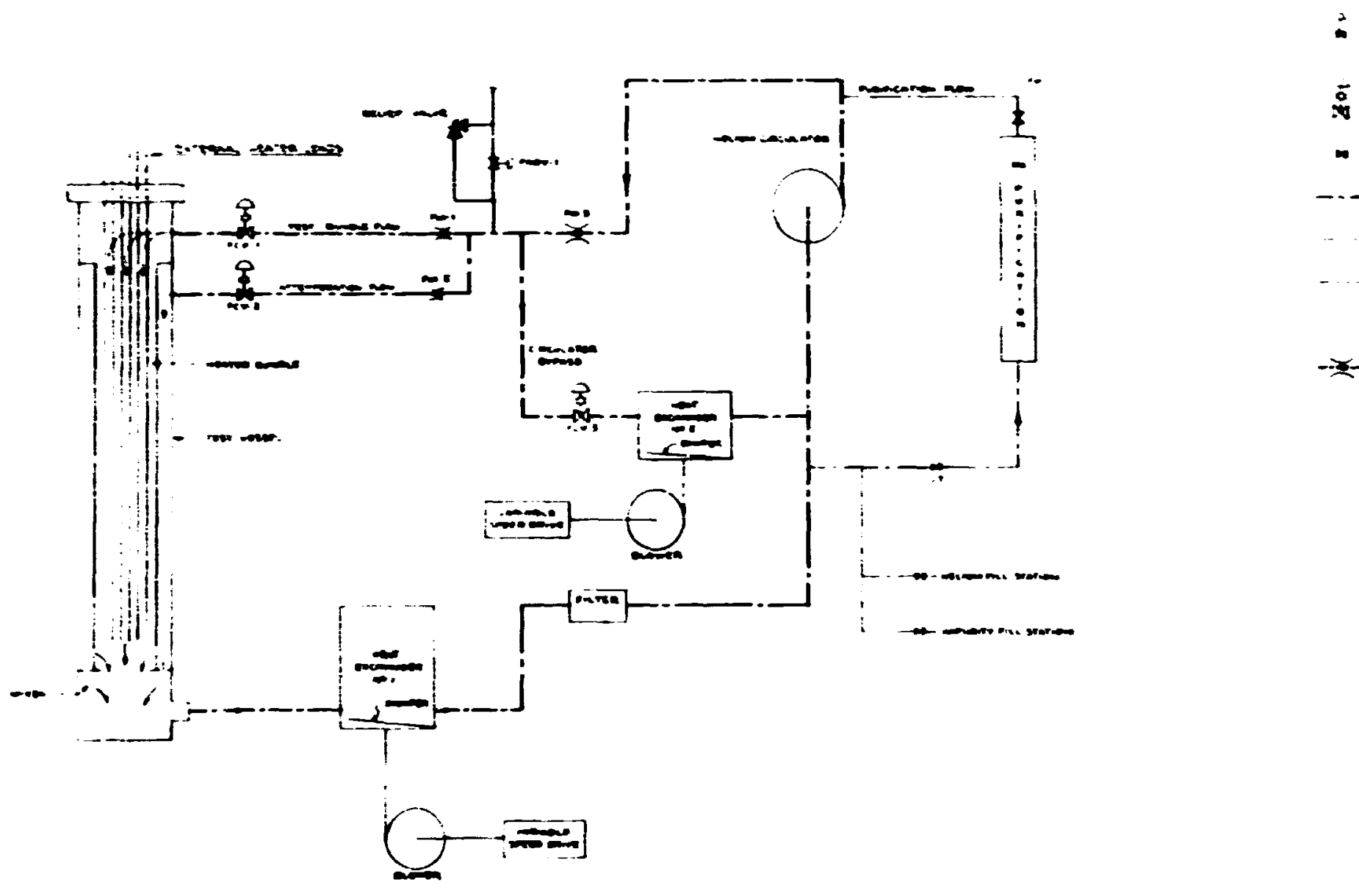

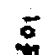

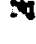

$\infty$

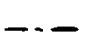

$-2-$
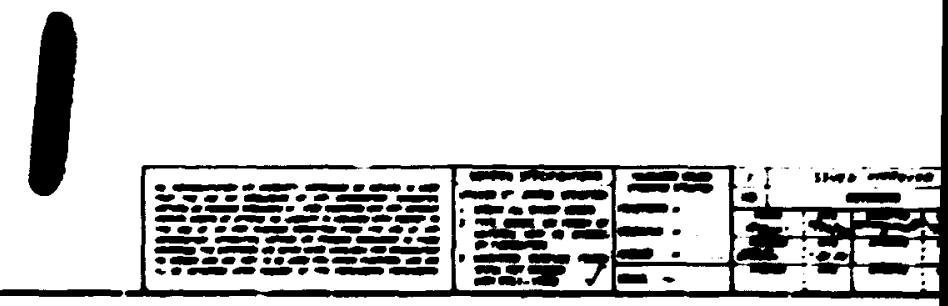

Fig. 3.4. Schematic Flow Diagram of GCPR Core Flow Test Loop (CFTL). 


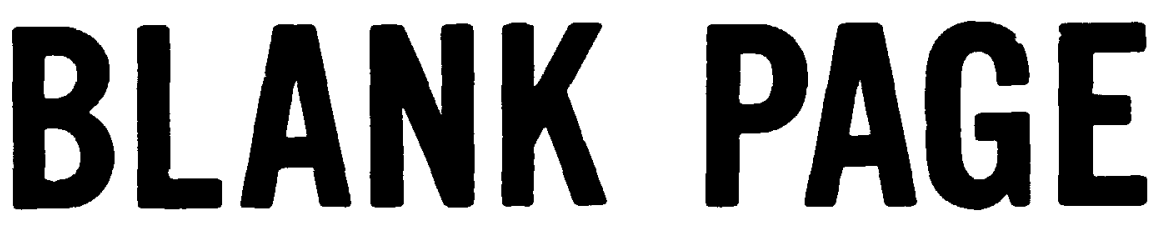



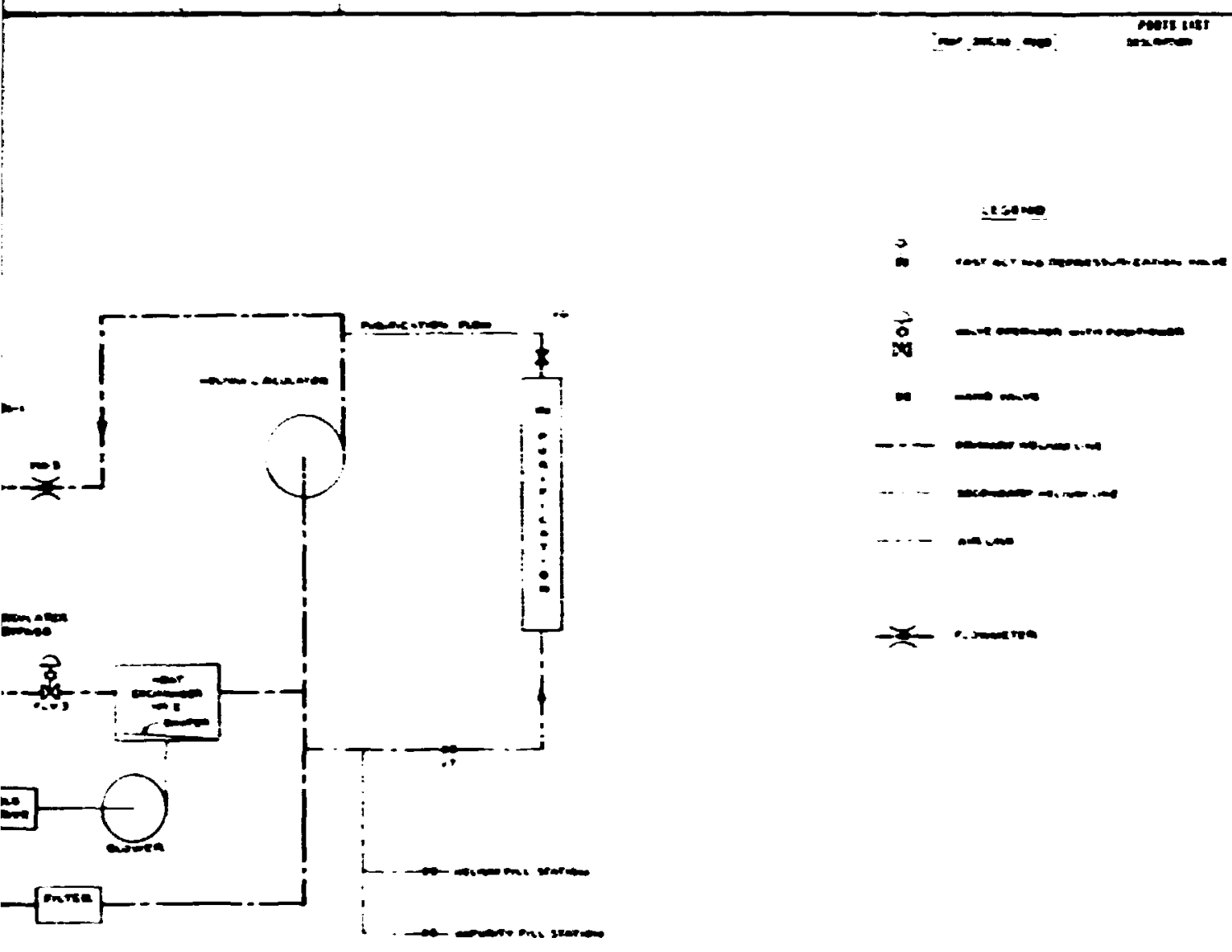

Schematic Plod Diagram of GCPR Core Flow Test Loop (CFTL). 
3.2 DMnATC SIMULATIOAS FOR INITIAL DESIGA STUDIES OF THE CORE FLOA TEST LOOP - S. J. Ball and R. A. Hedrick

Computer simulations vere used to predict the dyandc behavior of several proposed flow diagran for the heliu circulation systen tn the GCFR Core Flow Test Loop (CFT) to assist in the selection of adequate loop configuration and control system. The prinary design objective was to provide the capability of ilposing rather severe, but carefully controlled, flow, tenperature, power, and pressure transfents on the test section while at the sace tive aninizing the deleterious effects of the transieats on systea pressure boundaries. The siwulations indicated that satisfactory loop performace should be achieved with a configuration using two heat exchangers and three control valves; see Fig. 3.4 . One heat exchanger will remove test bundle heat and the other, installed in a bypass line around the heliun circulators, will reme circulator heat during certain wedes of operation. The three valves will need to be provided with programer-controlled fast woving stea actuators to achleve the required flow control of coolant heliun during fast transient operation.

The transients prescribed for the CFIL present not only control probless but also the need to aninize the deleterfous effects of the transients on loop pressure boundaries and components. Computerized simulations were ade of several flow diagrams to help answer loop design and contrcl option questions, such as the use of bypass lines, the locations of heat exchangers, flow control valves, and other components, and the coordination of stem position with tine for the flow control values. The results of the simulations were evaluated against two sets of criteria. On one hand, the operational requirements for the test section transients had to be satisfied. On the other hand, both the terperature transients experienced by the heat exchangers and circulators and the head and flow transients experienced by the circulators during power ead flow wodes of transient operations and systew depressurizations needed to be linted to "acceptable values."

Analyses of loop thermal and flow transients used the IBM simulation langunge Con:Inuous Syetea Hodeling Progran (CSYP), which perafted an efficient prograuding effort and rodest running tices and costs. 


\subsubsection{Description of Analyses}

\subsubsection{Flon Control Valve Studies}

Since the required flow transfents for the test section are quite fast (up to 907 change in $1 \mathrm{sac}$ ), the use of either circulator speed control or flow feedback control of the loop valves was deened infractical. Bence, a progran was Jevised to calculate the sten position vs tine for control valves FCV-1 and FCV-3 (show tia Fig- 3.4) required to give a specified test section illo transient and also to mininize changes in circulator head and flow.

The results of a calculation for a linear flow transieat from 100 to 57 are shown in Fig. 3.5(a). Valve stem positions for FCV-1 and FCV-3, which control test bundle and bypass flows, are shown for both linear and equal-percentage valve trill. Equal-percentage trin is that for which equal increments of stem notion will produce equal-percentage changes in flow, assuning constant pressure drop across the valve. It can be seen from Fig. 3.5(a) that the sten position prograns for both valves FCV-1 and FCV- 3 would be wre easily generated if equal-percentage trin were used.

Figure $3.5(b)$ shows siatlar results of a computation for a typical GCFR flow transient. The sane conclusions regarding valve trin apply here also. In both cases, the control of circulator pressure change remained within $0.7 \mathrm{kPa}(0.1 \mathrm{ps})$ of a $0.51 \mathrm{kPa}$ (75 psi) operating point, and the circuiator flow rate remained practically constant. Constant circulator speed was assumed.

\subsubsection{Depressurization-Flow Studies}

The simulation progran was extended to include depressurization transients as well as constant-inventory flow transients. The object of the CPTL depressurization tests is to expose the test bundle to pressure and flow transients that simulate the GCFR design basis accident; the conditions seen by the rest of the loop do not necessarily need to mock up GCPR conditions. Hence, GCPR hot leg and cold leg ruptures could both be siaulated on the CFT by bleeding from a single point (near the cest section inlet) and controlling the test section flos appropriately 

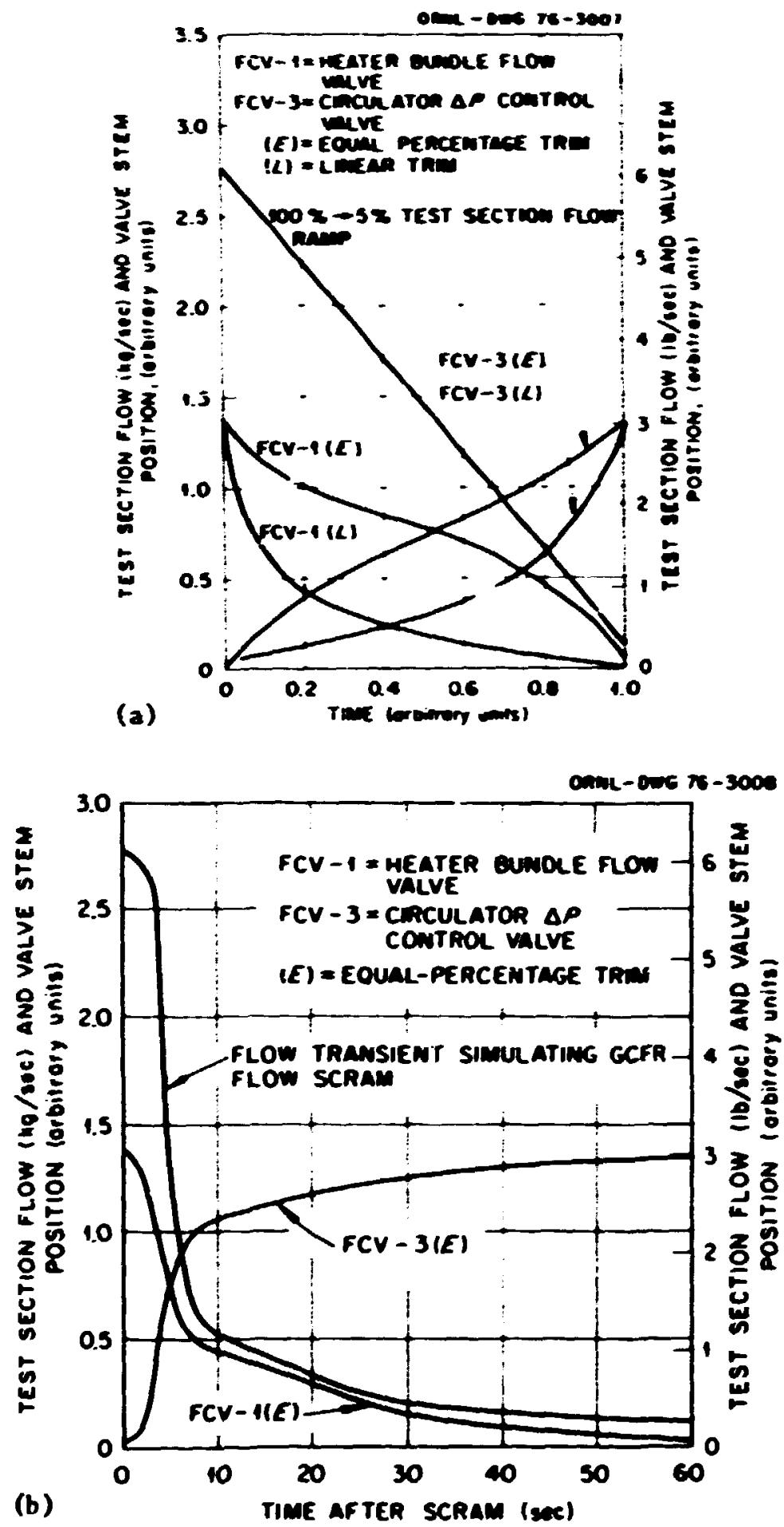

Pig. 3.5. Flow Rate and Valve Sten Positions Versus Tive for Plow Transients in CFTL. (a) Linear transient from $100 \mathrm{z}$ to $5 \%$. (b) Typical GCFR t ransient. 
with valve FCV-1. An Important consideration is the effect of the depressurization on circulators (i.e., whether or not they can be kept within a safe operating range). Effects of loop temerature changes on the flow calculations are also neglected here, although they will be included in later wre detailed analyses.

The results of a calculation in which the loop was depressurized from operating pressure to $0.2 \mathrm{lPa}(2 \mathrm{ata})$ in about 1.5 ain are shown in Fig. 3.6. In this run, FCV-1 was programed to try to duplicate the test section flow transient indicated for a $0.032 \mathrm{a}^{2}$ (50 in. ${ }^{2}$ ) rupture in a GCFR, and FCV-3 was used to attemt to enintain a constant chiculator head. The actual flow at the start of the transient falls short of the desired flow because the aximem opening of FCV-1 is linited. The circulator head variation was not serious (i.e., it went less than halfway between the operating point and the noninal thrust reversal 1init). The simalation also assumed that the circulator speed controller

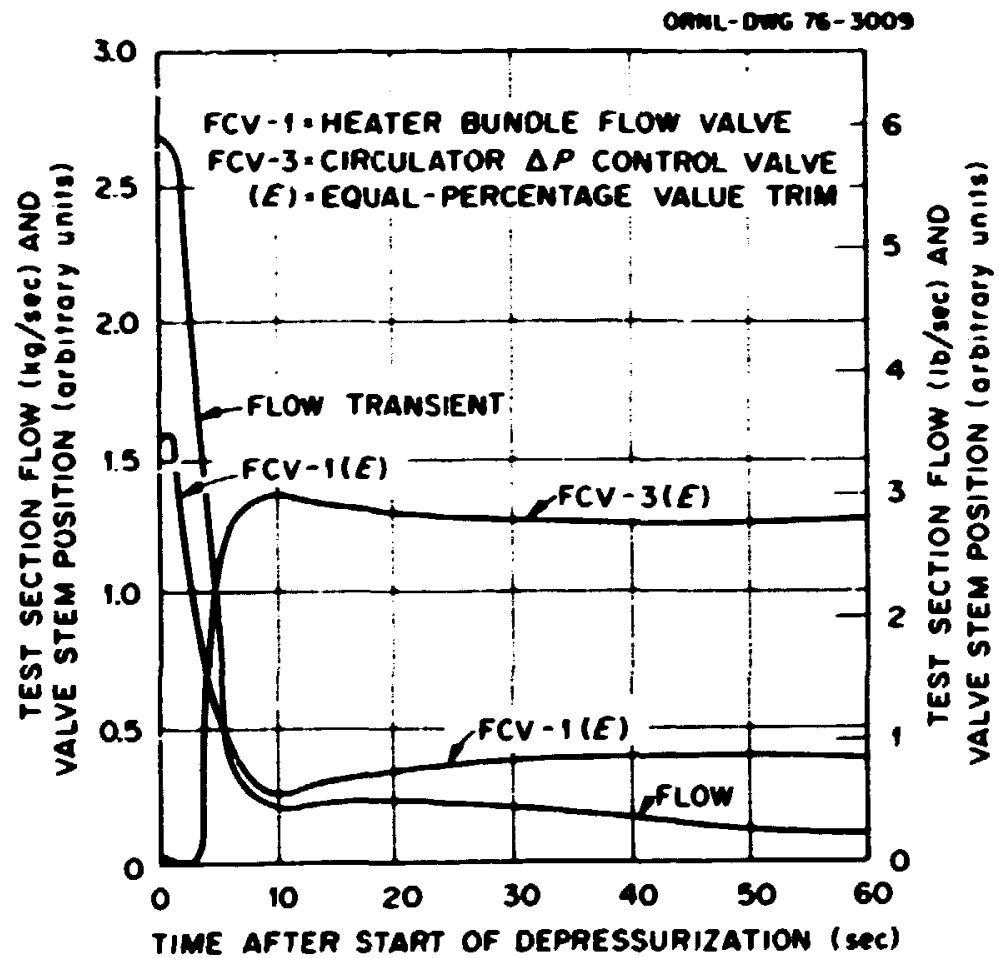

Pig. 3.6. Plon Rate and Valve Stem Position Versus Time During CFTL Depressuriz.1tion fro $9.0 \mathrm{MPa}$ (1300 psia) to about $0.2 \mathrm{MPa}$ ( $30 \mathrm{psia}$ ) in about 1.5 ain. 
was able to mintain a constant speed in spite of the rap!d loss of laad. This assuption should be checked when wre data become available. It my be concluded that reasonably good reproduction of the desired depressurfzation transients can be attained. If more accuracy is required at the start of the test, larger flow coeffictent for FC!-1 would we required. Rangeability requi rements are no wre stringent than for atwospheric pressure tests.

\subsubsection{Test Section Simulation}

The reference design for the test section was taken to be a 91-FPS fuel bundle with a typical simulator as show in Fig. 3.7. These FPSs have relatively short thereal tine constants ( $u$ sec at full flow), so fine-structure wodeling of thes was not crucial to calculating the transient behavior of the rest of the loop, which has wch longer response times. However, a five-radial-node simulation was wace both for comarIson with a gross (single-node) wodel and for studying the effects on cladding terperatures of several proposed power control schemes during power transients. Three axial regions were used to approximate the tamerature distributions along the flow path. At the time of the study, Insufficlent data on either surface roughening designs or local heat transfer crefficient $(h)$ values were avallable, so a uniforn, full-flow

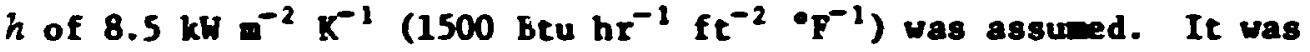
assumed to be Independent of temperature, but was varied as the 0.8 power of mass flow rate.

Figure 3.8 shows the calculated cladding terperature response to a power transient at full flow rate of test bundle coolant heliw. Cladding cooldown rates of $178^{\circ} \mathrm{C}\left(320^{\circ} \mathrm{F}\right)$ in $1 \mathrm{sec}$ and $411^{\circ} \mathrm{C}\left(740^{\circ} \mathrm{F}\right)$ in $4 \mathrm{sec}$ are seen. The transients seen by the aln loop heat exchanger would also be severe. This may indicate the need for a "flow scram" in case of a $108 s$ of heater power to avold deleterfous thermal quench of the bundle.

Control of the FPS bundle power was, for the initial simulations, assumed to follow the prescribed reactor power vs time values provided by GA. However, this assumption does not satisfy the test objectives 


\section{$=-\infty$}
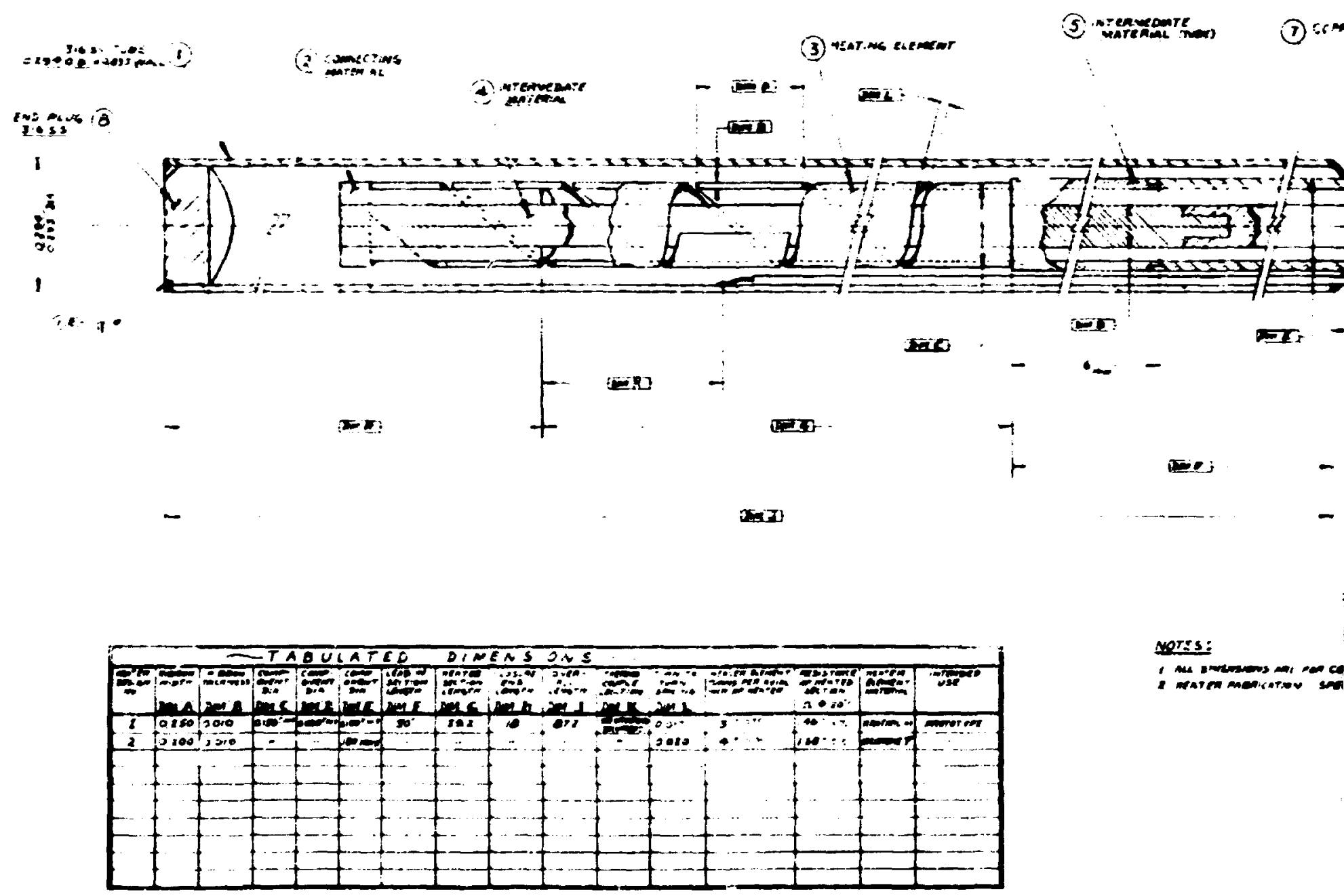

Ners:

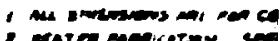

Fig. 3.7. Heater for CFTL Prototypical GCFR Fuel Pin Simulator. 


\section{BLANK PAGE}




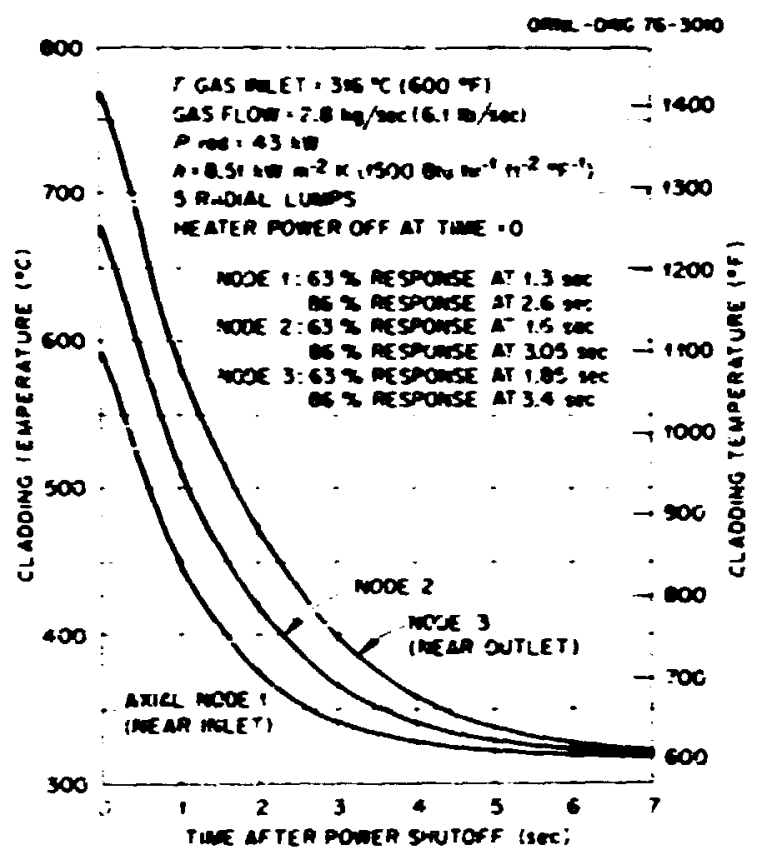

Fig. 3.8. Calculated CFTL Heater Cladding Tesperature Versus Tine after Power Shutoff at Full helluw Flow Rate through Test Bundle.

because the stnred energy in an FPS at nominal full-power conditions is only about one-tenth that in the $\left(\mathrm{UO}_{2}\right)$ fuel rod. Hence, a special computer program was witten to predict the FPS power transients required to give the heat flux or cladding telperature vs time to simulate the behavior of a fuel rod. In effect, the additional energy input to an FPS in the modified power transient compensates for its lower stored energy. This calculation requires an assumtion of the transient values of $t_{b}$ for the ertire bundle. It is expected that these can be derived by experibents. Various configurations were wodeled, Including partly roughened surfaces and nonunford power distributions. In all cases, the compensated power control appeared to be feasible.

\subsubsection{Total Loop Simulation}

The total loop simulations cosbined the cest section with sibulations of the two air-cooled heat exchangers, the c1rculators, and the assoctated piping. Mass flow transients were assumed to be controlled as specified, as opposed to having flows calculated from valve positions, temperaturedependent flow resistances, etc. These features will be combined in later simulations. 
The win loop heat exchanger nodel used four axial sections for accuracy at low-flow condition, while the bypass heat exchanger odel used only one section. Selected simulation rins in which test section puver and coolant heliun flow rate are reduced simultaneously at approximtely CCF scran conditions were mie primally to show the telperature transients inposed at the circulator inlet and the inlet to the min heat exchanger $(H X-1)$. We assumed that the cooling air flow rate to HX-1 is decreased in accordance with the test section transient, while the air flow rate to the bypass heat exchanger (HK-2) is increased sfmultaneously. Although the calculations show the heliun teperature fron $\mathrm{HX}-1$ exit decreases quite rapidly [approximately $22^{\circ} \mathrm{C}\left(40^{\circ} \mathrm{F}\right.$ ) in 1 secl, we found that after attenuation by the pipe thermal inertia and dilution with the bypass heliun flow (which rapidly reaches approxinately 9 times the value of the ain loop flow) the heliun temperature at the inculator inlet decreases only about $5.6^{\circ} \mathrm{C}\left(10^{\circ} \mathrm{F}\right)$ in $20 \mathrm{sec}$.

The results of an exanple calculation of a simulated depressurization accident are shown in Fig. 3.9(a) and indicate a modest initial increasc in cladding temperature $5.6^{\circ} \mathrm{C}\left(\sim 10^{\circ} \mathrm{F}\right)$. For the actual case, the increase wo:ld probably be greater because of the greater storad energy in the fuel. The eventual aximum cladding temperature exceeds $84^{\circ} \mathrm{C}\left(1550^{\circ} \mathrm{F}\right)$ because of a long-tern aismatch of $\mathrm{flow}$ and power. As was true of wost transients run,the circulator inlet temperature was well-behaved, as way be seen in Fig. 3.9(b).

\subsubsection{Loop Design Trade-0ff Considerations}

One of the primary reasons for the infitial CFTL simulation was to evaluate various alternative designs. The object was to minimize the cost and complexity of the loop while still mantaining a capability for running the prescribed transient experiments. A series of simulations led to the elimination of an auxillary heat exchanger paralleling the main loop exchanger, a heater-cooler unit upstream of the test section, and a second depressurization valve at the test section outlet. We showed that very little was lost in loop performance capabilities by eliminating these components. Further attempts to simplify the loopf..g., to eliminate the circulator bypass heat exchanger - were not practical. 

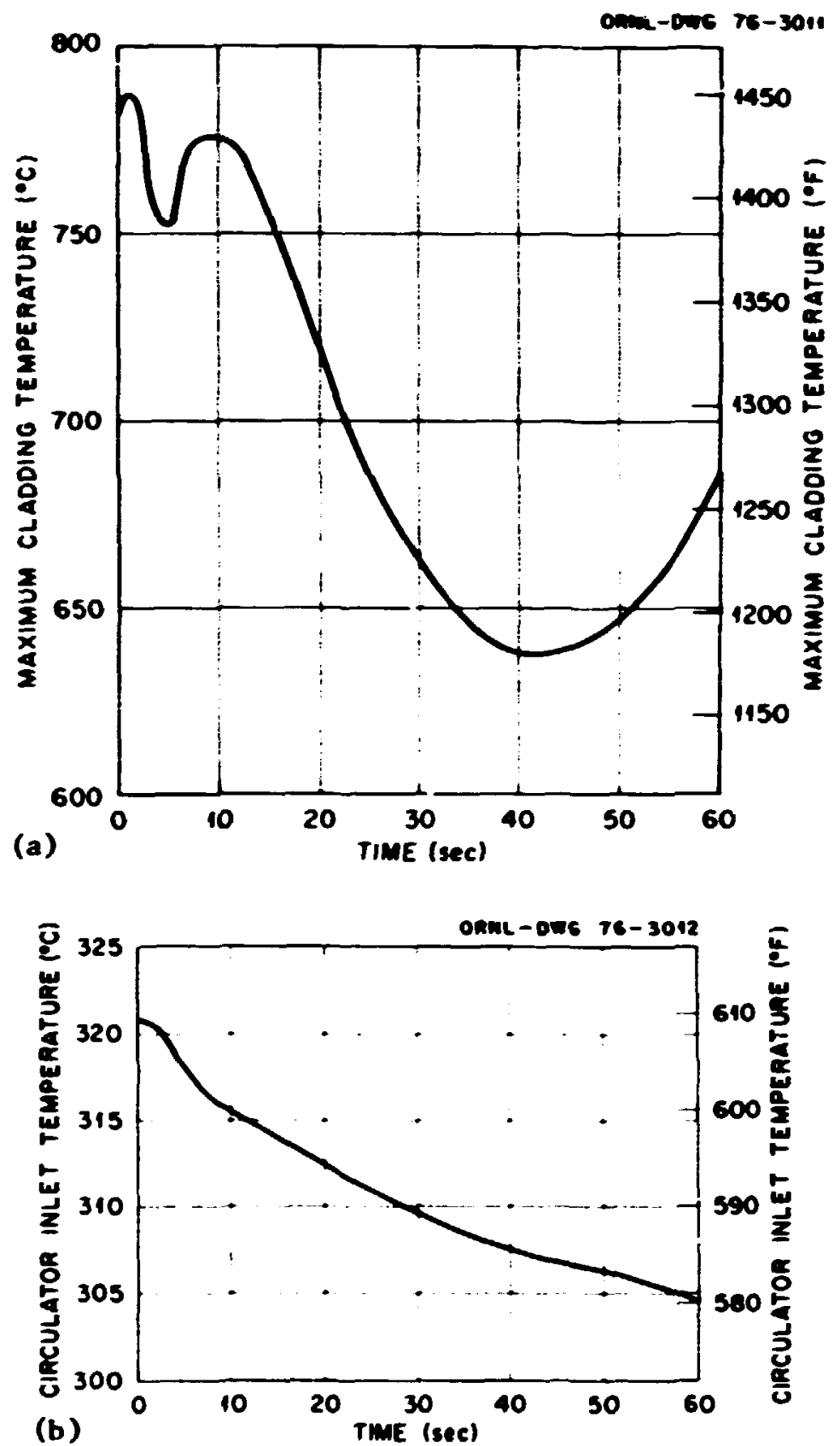

F1g. 3.9. Temperatures Versus Tíe in CPTL Simulated GCFR Depressurization Accident. (a) Simulator cladding temperature. temperature at circulator inlet.

(b) Hellum 


\subsubsection{Conclusfons and Recomendations}

Simulations of the transient behavfor of the conceptual design of the CFTL indicate that the proposed loop arrangenent and control schemes wil ake it possible to achieve the desired test section transients without imposing deleterious effects on the rest of the loop. Hille it is expected that a "satisfactory" conclusion vould be also reached even with pinor design changes and refinenents in the simulation codels, a wre detailed simulation is planned after the loop design becones wore fire.

3.3 COACEPTUAL DESIG - C. U. Collins and J. A. Seneker

\subsubsection{Loop Layout}

A conceptual loop layout was prepared to meet the functional and design requirements for the CFIL. Figure 3.4 presents the schematic flow diagran of the CFTL heliue systen, showing the principal cosponents and interconnecting piping of the helium flow paths and modes of operation for the CFTL. The principal path for coolant hellun flow during noral operation is from the circulator, which is wltiple single-stage equipment, through the test bundle in the test vessel, into heat exchanger $1(H X-1)$, and back to the circulator inlet to repeat the cycle. During rapid transients, the circulator flow cannot be decreased fast enough by changing its speed, so the heliun flow through the test section is changed by programed flou control valves, which cause the helliu flow to bypass the test vessel and HX-1 through the circulator bypass line, which includes heat exchanger 2 (Hx-2). An attemperation flow of helium will enter the test vessel separately from the test bundle coolant helium to mintain the vessel at a constant temperature below $427^{\circ} \mathrm{C}\left(800^{\circ} \mathrm{F}\right)$ and will be wixed with the bundle flow at the test bundle exit. The purification helium will flc's in a separate bypass line from the circulator outlet through the purffication system and then will reenter the helium syrten at the circulator inlet. Valve FADV-l peratis rapld depressurization of the CPTI.

During both steady-state operation and the various simulated GCFR transients the helfum coolant flow through the cest bundle, which will 
be measured with FH-1, will transport heat generated in the bundle to HX-1, an air-cooled heat sink designed to dissipate the maxim heat generation anticipated for the CFTL. The degree of nismatch that exists between GCFR reactor power and coolant heliun flow rater during various translents described in the progran plan will be simulated as closely as practical with test bundle power and helium flow rate.

As the test bundle flow is reduced to simulate a GCFR reactor trip, the circulator flow rate, which will be measured with Ft-3, wll be aintalned nearly constant by Increazing the flow rate in the circulator bypass line. HX-2 in this line will be used to remove circulator power during this time. Dynanic analysis Indicates that the helfw temperature at circulator inlet will change less than $27.8^{\circ} \mathrm{C}\left(50^{\circ} \mathrm{F}\right.$ ) during the simulated trip. Thus, the circulator operates at nearly constant conditions during a simlated trip without experiencing the rapid changes in temperature and flow rate seen b: the test bundle. During steady-state operation, a sinall atterperation flow in an annulus surrounding the test bundle wll maintain the terperature of the test vessel pressure boundary nearly constant. The attemeration flow path will also be used in the approach-to-cladding-melting operation. This operation starts frov steady-state design conditions, and at constant test bundle power the test bundle flow rate will be reduced and the attemperation flow rate will be increased in the sane increments to mintain constant the tosal helium flow rate throughout the test vessel. This wil protect the test vessel pressure boundary fron the very high teperatures in the test bundle and also maintain the heliun tespersture at teat vessel eadt neorly constant by aixing the atterperation flow with the test bundle coolant helium. Thus the terperature and flow changes Iuposed on the test bundle during approach to cladding melting will be substantially reduced or essentially ellminaced at $\mathrm{HX}-1$ and at the circulator.

The impurities that are required by the progran plan for the coolant hellum will be introduced in a controlled anner into the hellun system through the imurity fill station. The impurities my react for a tix with the hellum system components to me other chendcal form, which w11l be removed in the hellum purification systen from a small side streas 
of heliu to attain and mintain the piscribed ipurity conditions. A code of operation wil be sought to mintain the ilpurity levels in the heliue systen wile aninizing both the rate of ifpurity injection into the beliu systee and the flow of cleanup heliu through the purificacion systen.

The depressurization valve, FADV-1, vill pernit rapid reduction in the CFIL heliu pressure from maxim operating pressure of $10.13 \mathrm{rPa}$ (100 ata) to as low as $0.2 \mathrm{MPa}(2 \mathrm{~atm}$ absolute) in as short a tine as $60 \mathrm{sec}$.

A pipe size of 0.15 a (6 in.) was chosed for the hellu systen intercomecting piping over a 0.1-n (4-in.) size to reduce the heat requirement for the circulator; the velocity heads vere about one-fourth as weh with the larger pipe.

Coolant helfur flos rate through the test bundle is regulated priarily with a valve having a fast-acting hydraulic operator that is coitrolled either anually by the operator or automicically with a programer. In general, the circulator will be operated at constant speed to obtain the madm coolant flow requirements for the buadle size being tested. The heat generation rate in the test bundle is reguiated with an electroaic controller that is either mually controlled by the operator or autonatcally controlled with a progranser. The enuul controls perait the operator to obtain the various steady-state operating cooditions of bundle coolant flow rate and power required for the CFTL. Simultaneous programed regulation of the independeac controls for coolant helfu flow rate and test buadle power wil be provided to pernit simulation in the CFIL of all the anticipated GCFR flow and power transients. The programed regulation will also control the cooling alr flaw rate for $1 \mathrm{x}-1$ and $\mathrm{AX}-2$ during transient operation to anidize the change in helfu temperature at the circulator inlet.

The tnst vessel inlet will be designed to assist attaining fully developed flow in the test bundle flow channels upstrean of the start of the heated zone, which simulates the fueled section in a GCFR fuel pin. A axer will be designed for the test vessel at the outlet of the 
test bundle to $\mathrm{ax}$ the cooling atterperation flod from the annulus with the high-teeperature helfio from the test bundle. Also a full-flod filter will be install ad in the piping fondiately dowstrean of the Hx-1 outlet to protect the downtrean composents fron debris that would be produced if the bundle heater cladding actually melted during approach-to-cladding-elting operation.

The bellue systen components and interconnecting plping will be made of austenitic stafiless steel for a design pressure of $11.72 \mathrm{kPa}$ gage (1700 psig), which will provide margin for the operation of pressure relief equipment sbove the mximu vorking pressure of $10.34 \mathrm{MPa}$ (1500 psis). The systen components are sized to accomsodate $32 \mathrm{~kg} / \mathrm{sec}$ (7 1b/sec) of hellu at $8.96 \mathrm{gPa}(1300 \mathrm{psia})$ and $343^{\circ} \mathrm{C}\left(650^{\circ} \mathrm{F}\right)$ except the purification system, which is sized to accomodate heliun flow rates up to a maxim of approximately 1 std 11 ter/sec $(2 \mathrm{cfm}$ ) at $10.34 \mathrm{MPa}$ (1500 psia).

Tire heat sinks will be sized to reject $4700 \mathrm{kH}$ for $\mathrm{kX}-1$ and $600 \mathrm{kH}$ for $h x-2$. A 4.1-ki electrical power and control systes will be provided to supply the test bundle.

\subsubsection{Loop Characteristics}

Because the CFTL will be constructed to simlate power and coolant heliu transients that are being anticipated in the design of the GCFR Demonstration Plant, thought was given in the conceptual design to enhance the reliable operation of various components of the helliu systea by protecting then as practicable from the deleterious effects of these transients.

Although both test bundle power and coolant heliun flow rate are reduced simultaneousiy and programatically in simulated GCPR transients, there is sufficient aismatching to change coolent heliu tesperature distribution in the test bundle. However, the controls of the system will be designed to wintaln nearly constant the helfu temperature at the inlet to the test bundle and both hellus tepperature and flow rate at the inlet to the circulator. The circulator bypass valve, PCV-3, will be opened to increase bypass flow rate as closely as practical to 
the increnent the test bundle flow rate is being dacreased to mintain the be:iu flow rate at circulator inlet nearly crastant. The flow rates of cooling air to $\mathrm{Hx}-1$ and $\mathrm{Bx}-2$ will be regulaced to mintain the terperature of coolant belfu at the test bundle inlet and circulator inlet as nearly constant as practical.

In an approach to cladding welting the bundle pover is mintained constant while the coolant heliun flow rate is reduced incrementally. The acteaperation flow rate through the amnulus that surrounds the test buadle will be increased increnentally so as to mintain constant the helfu coolwat flow rate through the test vessel, : $x-1$, asd the circulator. Thus both the heat load on bx-1 and the cirsulator loas will remin constant.

Results of prelininary dynaic analysis of simlating the GCFR depressurization incident indicate that there should be no sigificant changes in coolant heliun tenperature at the circulator inlet.

When the CFTL is scramed, which will occur primarily upon loss of coolent heliun flow to the test bundle or loss of helfu systee pressure, the signal will cum of the test bundle power automtically and inediately protect the simulators. The circulators and the cooling air blowers to $\mathrm{bx}-1$ and $\mathrm{Hx}-2$ will be turned of $f$, and the air flow control valves at the inlets to the blowers will be closed as appropriate to reduce the cor sequential effects of the thermal quench on the heliun systed components.

\subsubsection{Loop Arrangement}

Figures $3.10,3.11$, and 3.12 show the plan and elevation views of the CFTL conceptual design for the arrangerment of the components and interconnecting piping in the helfu systes. The locations of the transformers and other suttch gear for the loop electrical systen, she control roon and various controls, a crane for handling test bundles, and ducting and blowers for the heat sinks ste shown also. The outline of the enclosure to protect personsel from contact with the high-tenperature components of the loop my be seen also. 


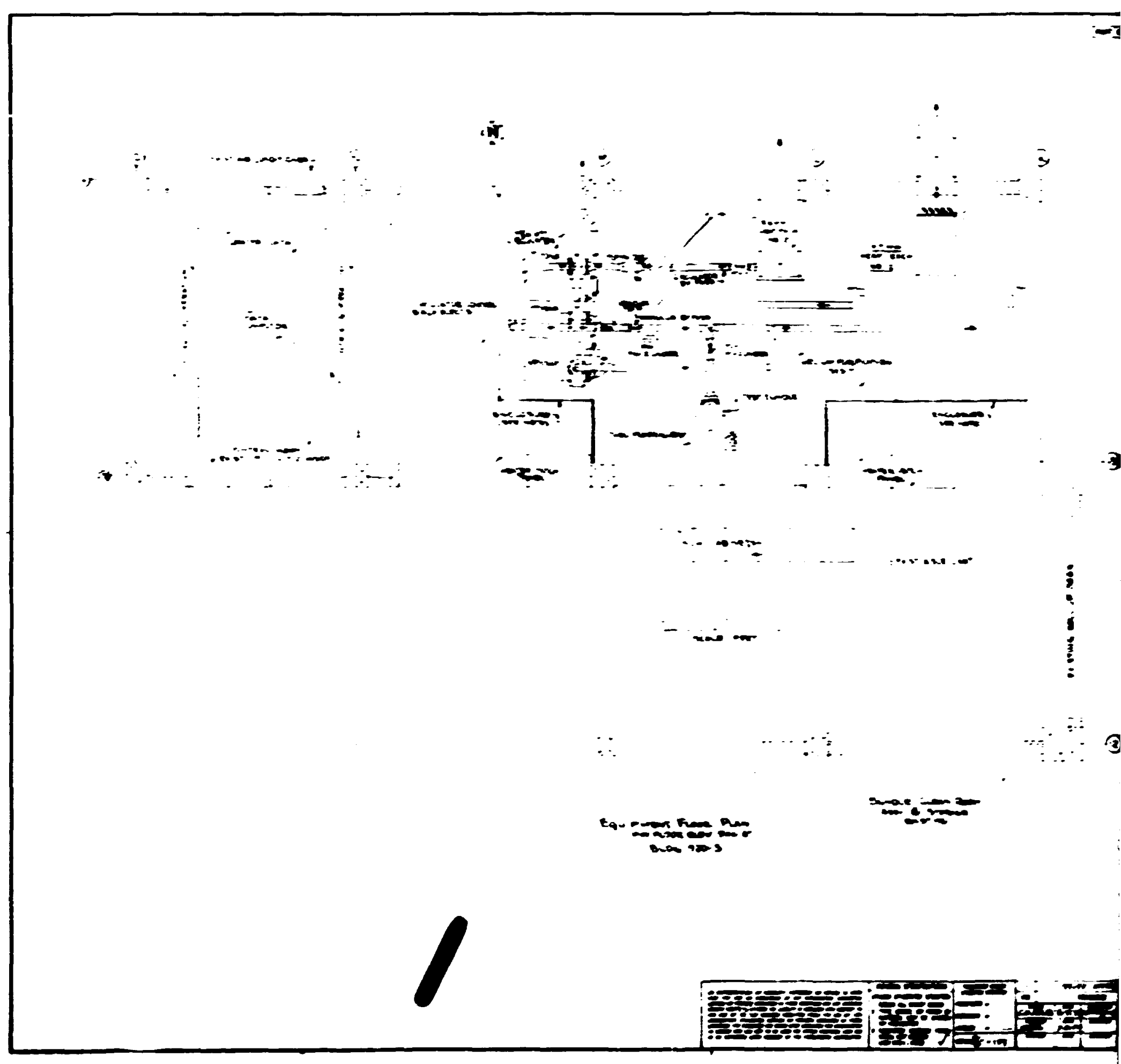

Fig. 3.10. Plan View. Proposed Layout GCFR Core Flon Test Loop (CFTL). 


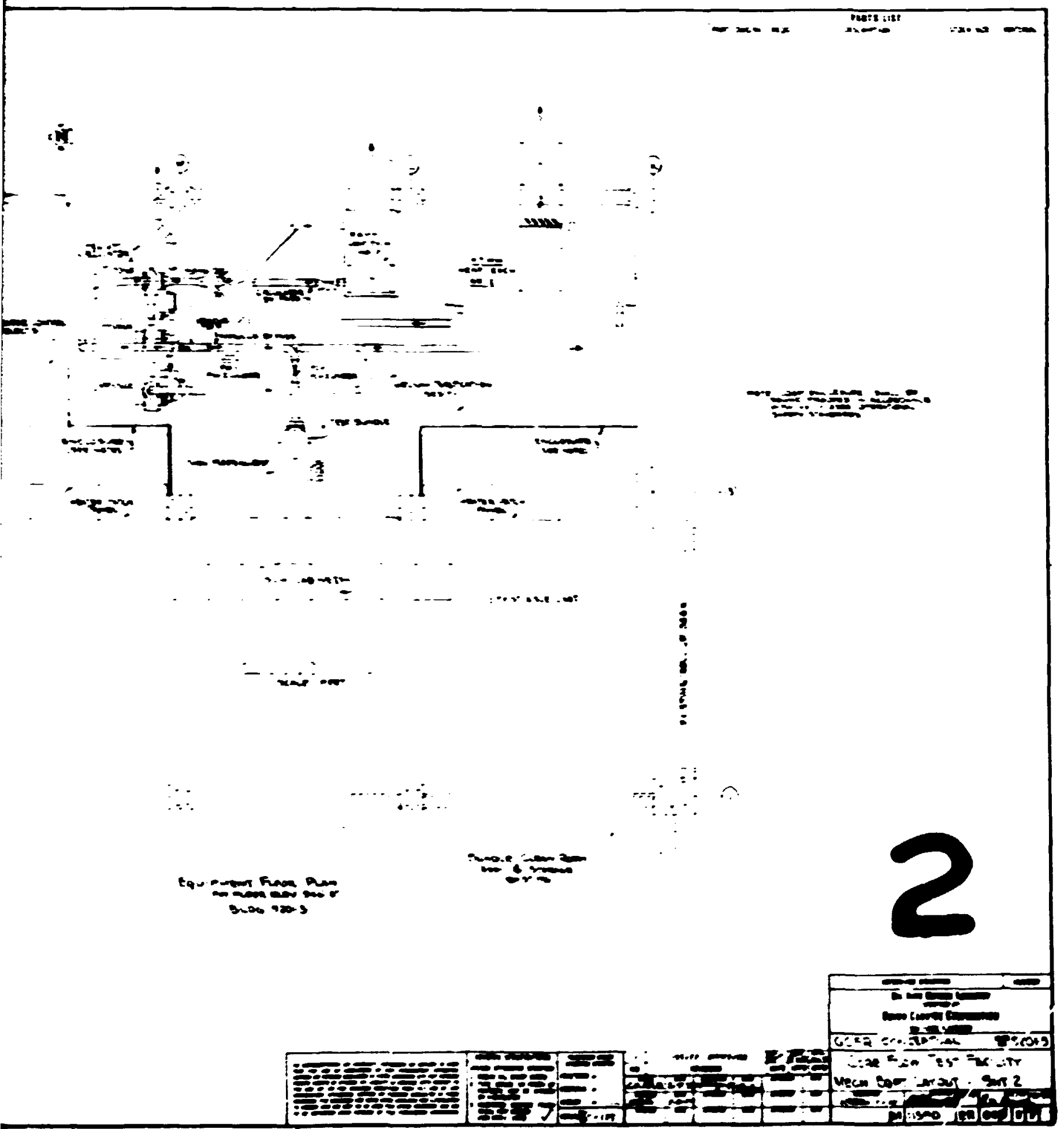

Plan View, Proposed Layout GCFR Core Flow Test Loop (CFTL). 
8

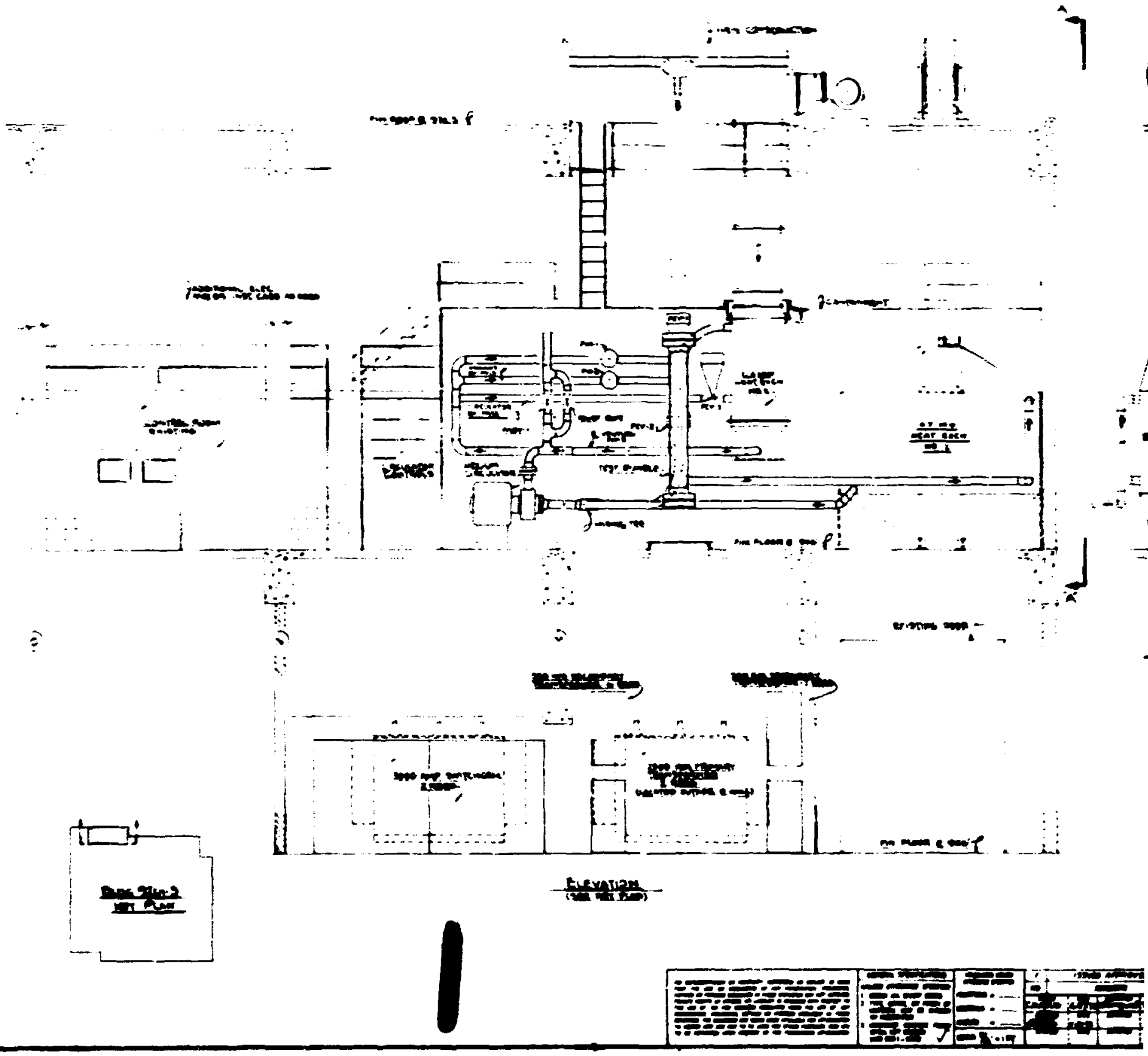

Fig. 3.11. Elevation, Proposed Layout GCFR Core Flow Test Loop (CFTL), 


\section{BLANK PAGE}

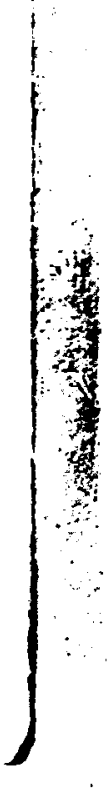


(1)

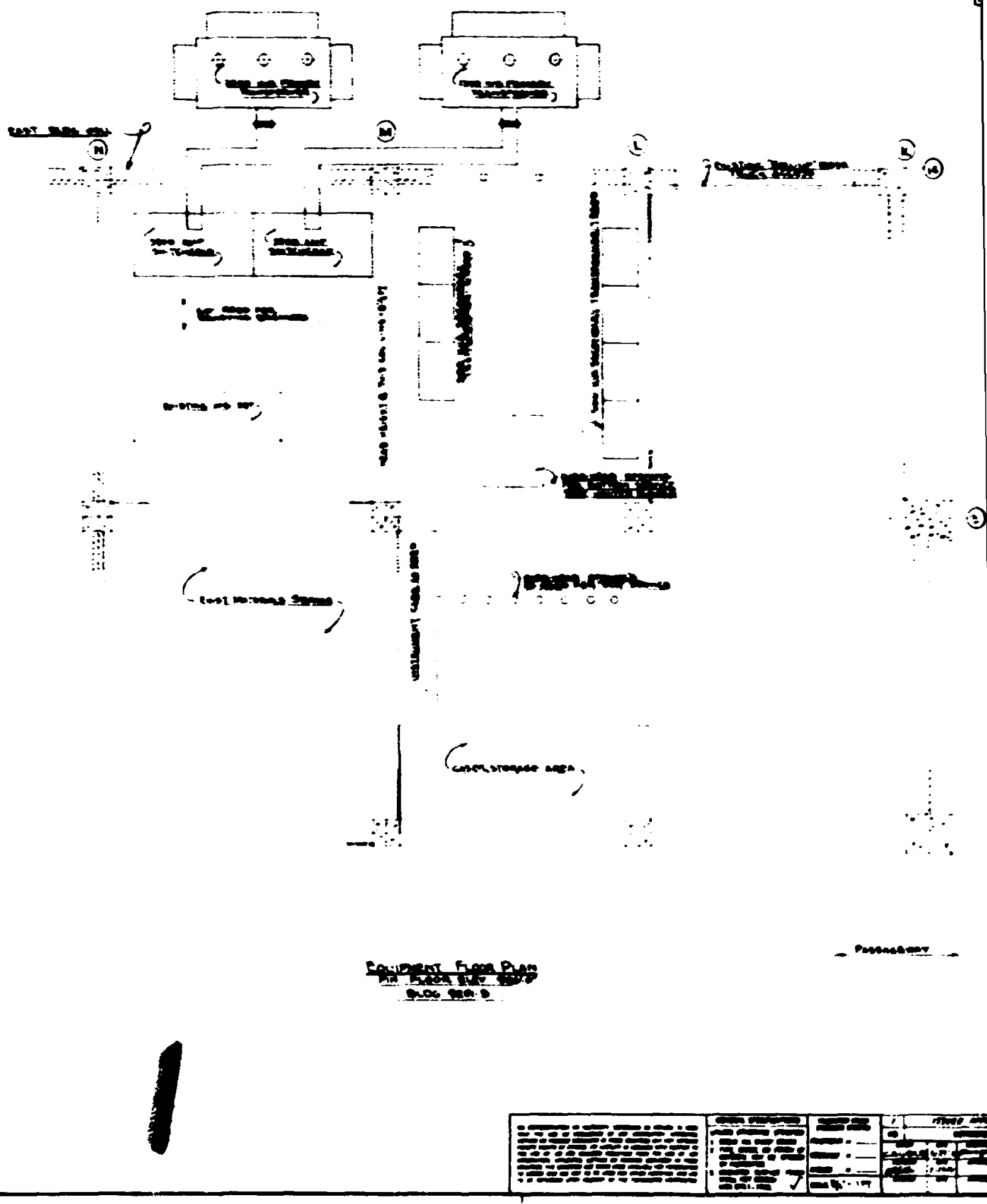

P1g. 3.12. Plan V1ew, Proposed Layout, Electrical System GCPR Core Plow Test Loop 


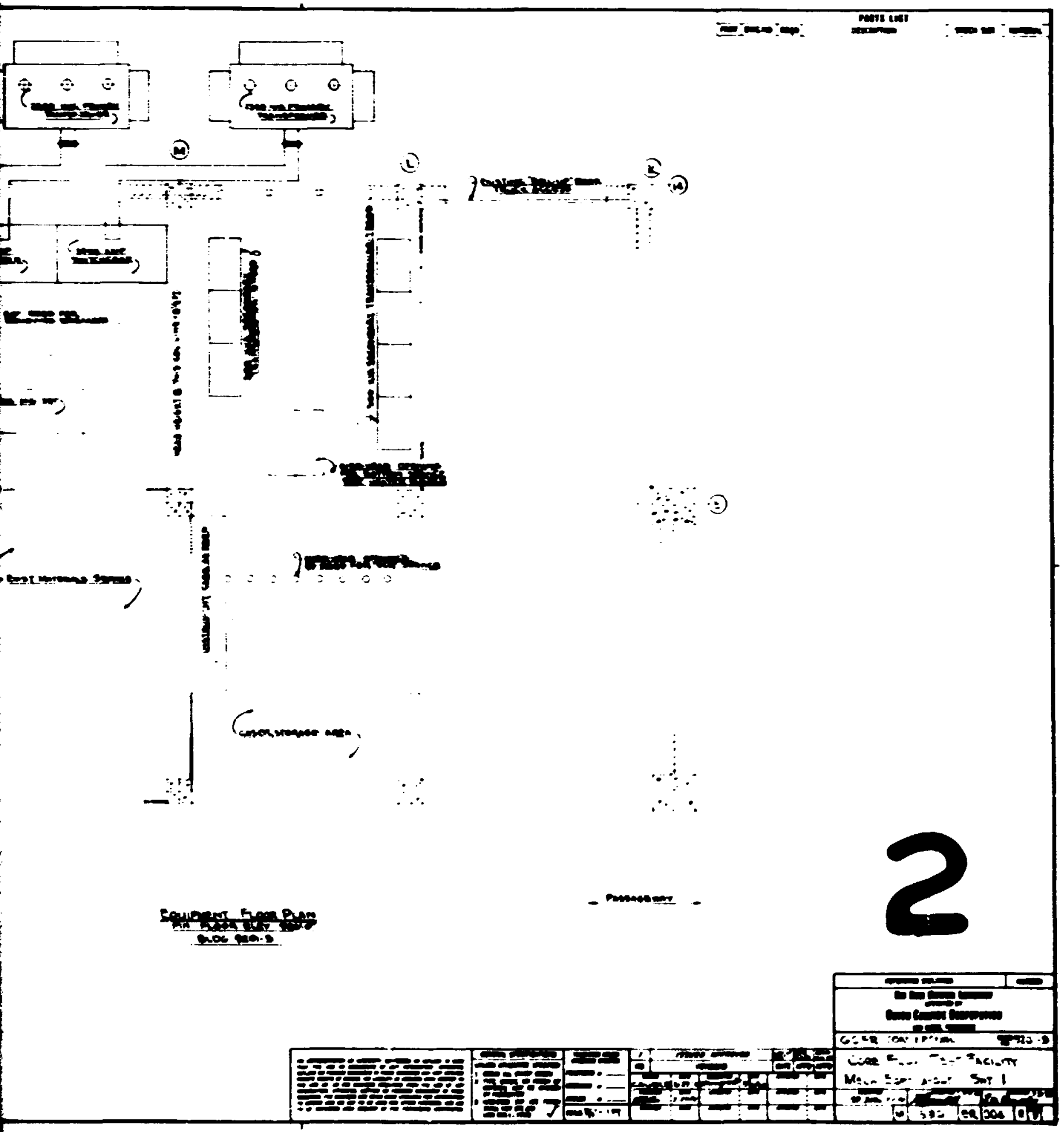

, Proposed Layout, Electrical System GCFR Core Plow Test Loop (CFTL). 

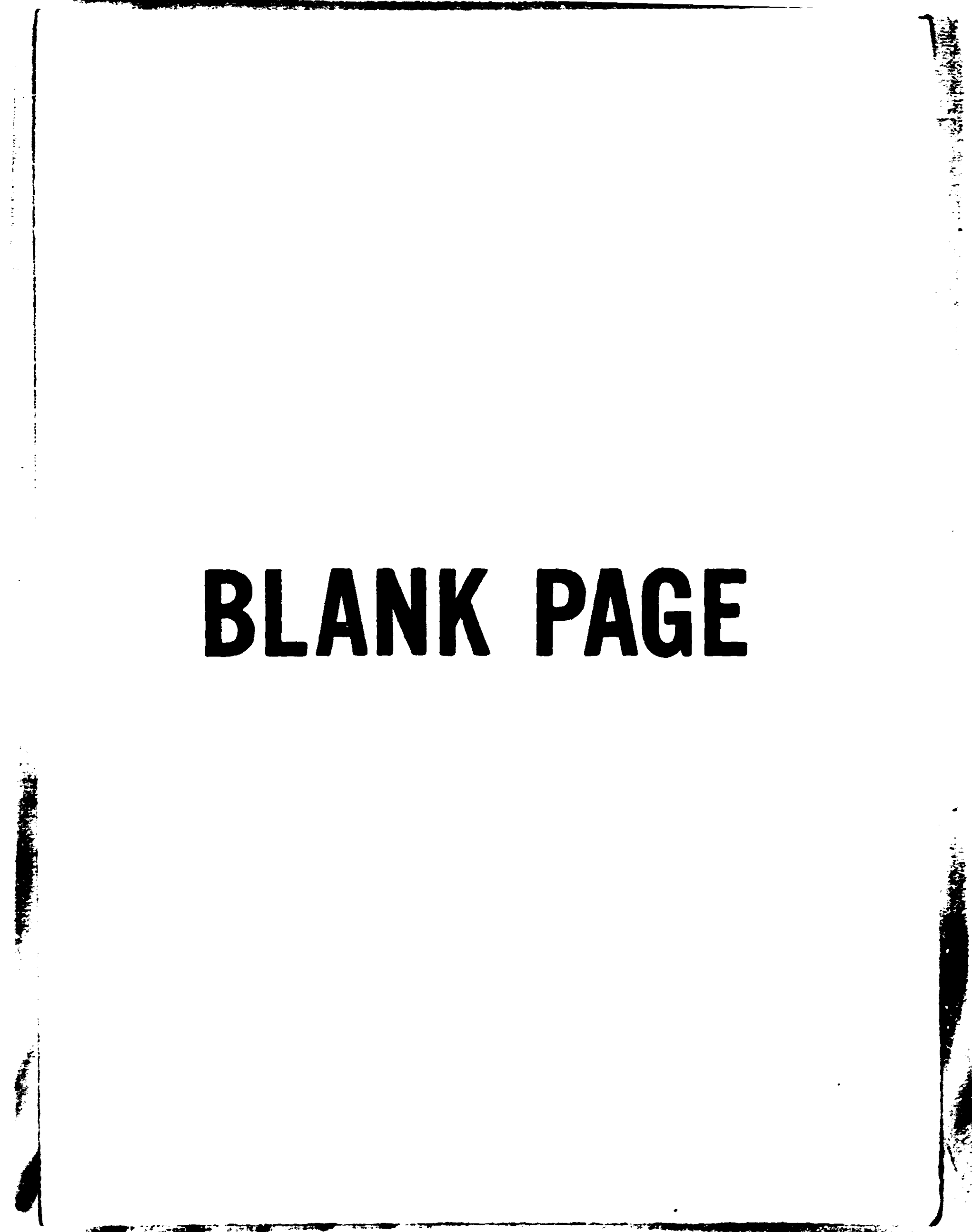

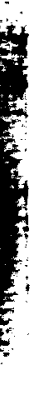




\subsubsection{Loor Conponents and Systers}

\subsubsection{Beat Sinks}

Each of the two heat sinks in the CrTl helfue systen will consist of a bellu-to-air heat exchanger with the requisite blower, ducting, and controls for the cooling afr. The larger beat sink, Hx-1, located dounstrean of the test vessel exit, will reject the test icundle heat and heliu circulator power to the cooling air. The smiler heat sink, EX-2, wich will be located in the circulator bypass line, will reject circulator pover during the flor transients when there will be a sall flow of coolant heliu through the teat bundle and a large flou through the eirculator bypass line. Drring normal operation there vill be a sall flou of hellue through $\mathrm{Ax}-2$ to mintain the bypass line near systen operatiag conditions.

The pressure-retaining boundary of the heat exchangers will be classified, desigoed, and constructed to the requirenents for Class 2 PIping Components in Section III of the ASHE Boiler and Pressure Vesse Code. The design pressure for both heat exchangers will be $11.72 \mathrm{HPa}$ (1700 psia). The design temperature for $\mathrm{kx}-1$ will range from $593^{\circ} \mathrm{C}$ $\left(1100^{\circ} \mathrm{F}\right)$ at the inlet to $399^{\circ} \mathrm{C}\left(750^{\circ} \mathrm{F}\right)$ at the outlet. The design temperature for $\mathrm{HX}-2$ will be $399^{\circ} \mathrm{C}\left(750^{\circ} \mathrm{F}\right)$.

The Ax-1 will be designed to reject axime of $4.7 \mathrm{~m}$ heat to a forced draft of abbient air while cooling a hellun flow of 2.76 to $2.95 \mathrm{~kg} / \mathrm{sec}\left(6.1-6.51 \mathrm{~b} / \mathrm{sec}\right.$ fron 538 to $316^{\circ} \mathrm{C}\left(1100-600^{\circ} \mathrm{F}\right)$. The $\mathrm{HX}-2$ will be designed to reject $0.6 \mathrm{k}$ heat to a forced draft of ambient cooling air while cooling a heliun flon of 2.76 to $2.95 \mathrm{~kg} / \mathrm{sec}$ (6.1-6.5 1b/sec) from circulator outlet to circulator inlet temperature.

For both exchangers ablent cooling alr from outside the bullding wil be coved by blower and ducted to the heat exchanger and then returned outside the building. The flow of air will be controllable with variable speed blowers and novable louvers or vanes installed at the cooling air inlet to the heat exchanger. 


\subsubsection{Heliun Purification Systee}

The CFTL wst have the capability of duplicating the anticipated ranges of GCFR heliun ifpurity levels. Since the CFTL helliw will be obtained fron the U.S. Bureau of Mines to high purity specifications, It will be necessary to introduce impurities into the heliu and then to establish the required level of impurity by the use of the purification systen.

The pressure-retaining boundary of the helium purification systen will be designed for 11.72 YPa $(1700 \mathrm{psig})$ and $399^{\circ} \mathrm{C}\left(750^{\circ} \mathrm{F}\right)$ and com structed and stamped in accordance to the rules of Section VIII, Division I, of the ASME Boiler and Pressure Vesse 2 Code (the Code). Prelininary inquiries of U.S. Industry indicated that the cost for construction of the purification systen to the rules for class 2 section of the Code would be higher than for construction to the rulas of Division I, Section VIII. Because the purification systen is ancilliary to the hellun systen ane can be isolated fron it with stop valves, we elected to use the rules of Division I, Section VIII of the Code.

The performance requirements for the purification system will be a maximun of $0.94 \mathrm{liter} / \mathrm{sec}$ (2 scfa) of helfun flov at inlet conditions of $10.34 \mathrm{LPa}$ (1500 psis), mximan and $34^{\circ} \mathrm{C}\left(650^{\circ} \mathrm{F}\right)$ maximu with a pressure drop of $2.75 \mathrm{kPa}$ ( $40 \mathrm{psi}$ ). The inlet and outlet of the purification systea dill be connected, respectively, to the outlet and inlet of the circulator to provide the pressure drop. This performance should peratt the mas of system helium to be processed through the purification systen as fast as once per hour during a continuous two-week period before the systen requires regeneration.

Prelininary informtion indicates that the purification systen will probably consist of regenerative heat exchangers, "Deoxo" catalytic purifier to convert hydrogen and oxygen to water, a copper oxide purifier to convert even wore of the hydrogen and oxygen to water and carbon dioxdde, a molecular sieve bed to absorb the generated water and carbon dioxide, and a low-tenperature absorbent bed to temove the nitrogen, hydrocarbons, and other gases not collected in the molecular sieves. 


\subsubsection{Belfur Supply Systee}

The CTT heliu supply system will actually consist of two separate, although interconnected, subsystems: (1) the charging subsysten. wich wil provide the large amout of heliu required for filling the loop and pressurization from atmosheric to operating pressure, and (2) the nkeup subsysten, wich wil provide the helium required to maintain the loop at operating pressure.

Analysis of the present concept of the CFTL indicates that the wolue of hellum in the losp is approximately $2.5 \mathrm{a}^{3}\left(90 \mathrm{ft}^{3}\right)$. The mas of heliun needed to reach $10.34 \mathrm{rPa}$ (1500 psia) and $343^{\circ} \mathrm{C}\left(650^{\circ} \mathrm{F}\right)$

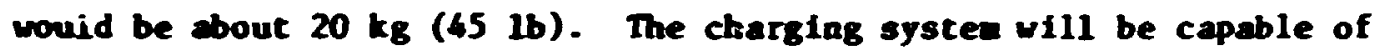
supplying this beliu from a high-pressure heliu traller through a maifold station and interconpecting 25-m (1-in.) piping to the fill port on the CFIL. The systen will have the capacity to make four fills of the CFTL. Each fill will be ade from atwosheric pressure to $4.82 \mathrm{MPa}$ ( $700 \mathrm{psia}$ ) at roon temperature and will be accomplished in less than $1 \mathrm{hr}$. A sufficient mas of heliu will be introduced into the CFTL in this manner to achieve the desired operating pressures at operating cemperature. The systen will ake use of the helfun trailer rather than numerous stall helium cylinders because the cost of heliu used is mich less when supplied fron a bulk source.

The makeup helium system will be located just below the CFTL on the first floor of the sice building. Tentatively. two banks of ten botcles of heliu each will be installed on:o a helium manifold and connected to the CFIL with 25-w (1-in.) piping. Each bank would have the capability of injecting $1.8 \mathrm{~kg}\left(\begin{array}{ll}4 & \mathrm{~b}\end{array}\right)$ of hellum trto the heliun systew in as short a time as 5 ain with the CFTL pressure as high as $9.31 \mathrm{MPa}$ (1350 psi) from fully charged botcles. Alternatively, the makeup heilun will be supplied from the traller.

\subsubsection{Test Vesse1}

The CPTL test vessel, Fig. 3.13, will contain the test $t$. . d le that simulates a segment of a GCFR core element. The vessel will be :ylindrical and will have bolted and seal-welded flandes at the top and botcom. Test bundles will be inserted through the top flange. 


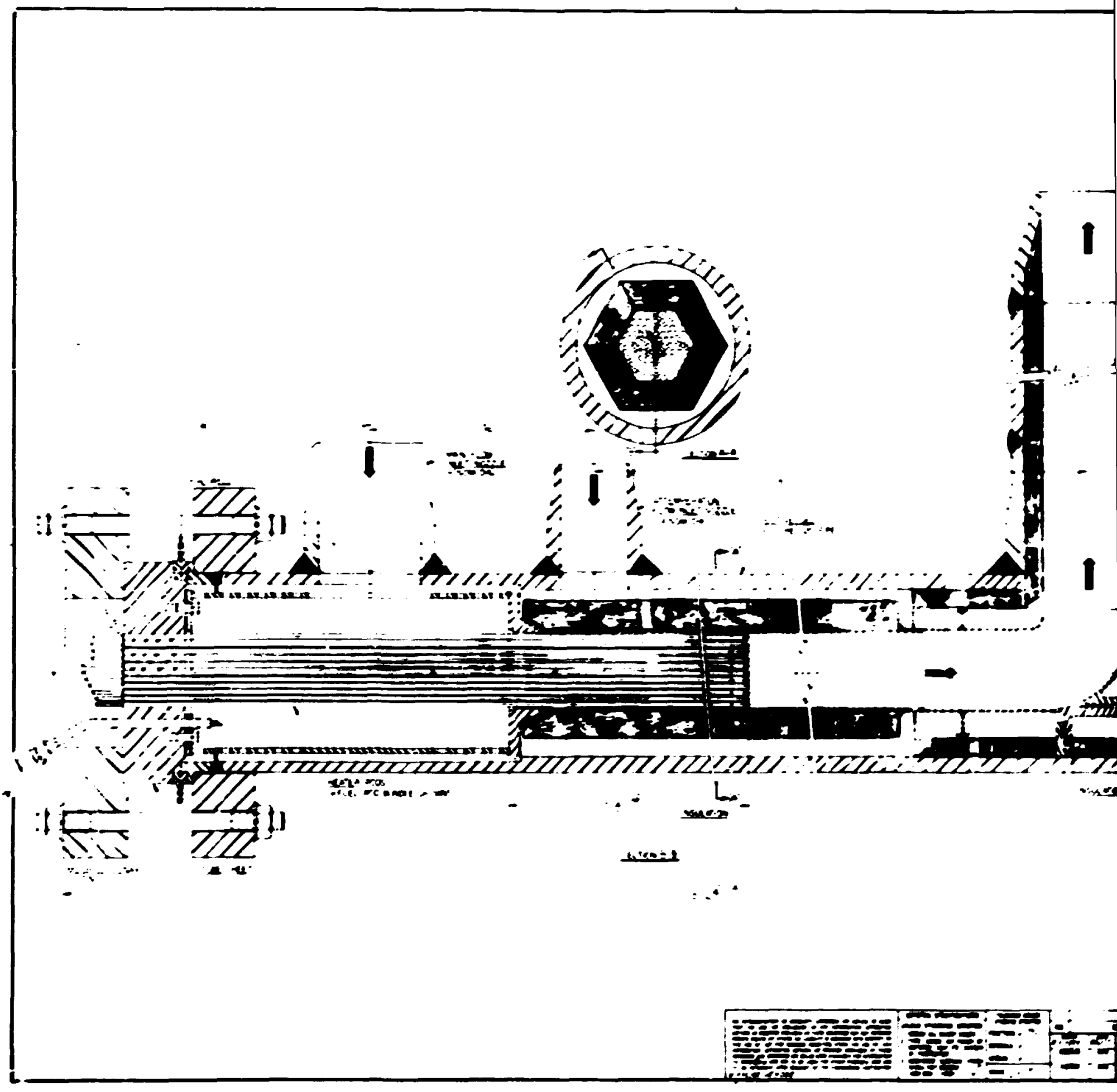

F18. 3.13. CFTL Test Vessel. 


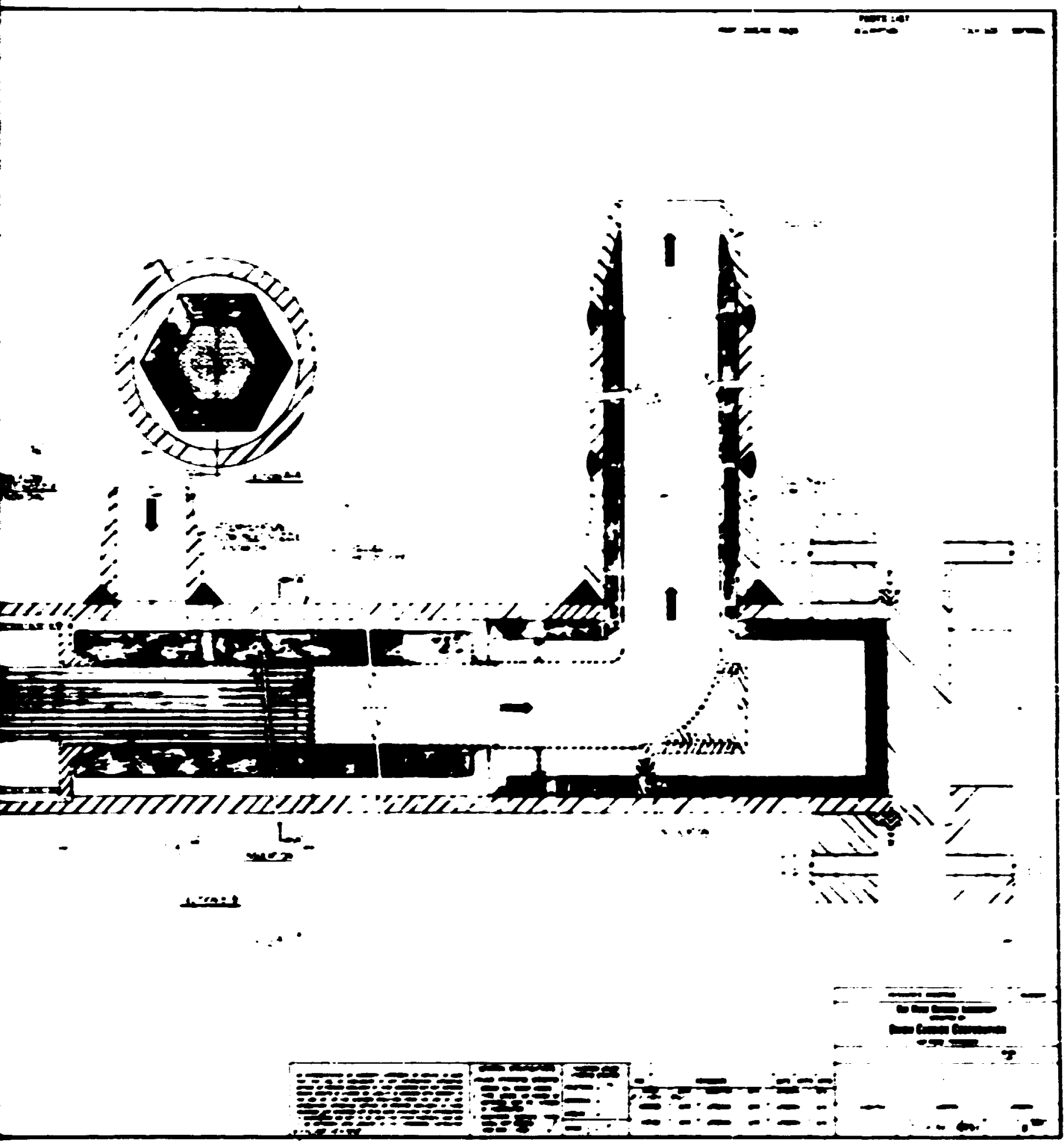

Fig. 3.13. CFTL Test Vessel.

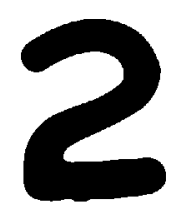


At the present tife conceptual layouts of the test ressel are being ade. The present design of the cylindrical portion of the vessel is a $0.25-10$ (10-in.) sched 120 stainless steel pipe, wich appears ta be large enough to accomodate all budles to be tested. The total length of the cest vessel, top flage to botton flange, will be 3.30 to 3.81 a (130-159 in.).

Several concepts of the out let dxing chaber are still belag cvaluated. To such concepts are: a baffled arrangenent doumstrean of the test buodle exdi, and a perforated ca between the two flou passages, which would allon the atcenperation flon to be injected at relatively high velocity ints the test buadle outlet flou. The inlet plenu is preseat is a woluse contaiaing the top portion of the sinulator from the top flange cubesheet down to the first spacer grid in the laver portion of the buodle, referred to to the cest section because it is the test simblation of a portion of a CCrin core elenent. Studies are uder way to deterndac if this desiga will allow the belio flod co become fully established as in an actwal core elemeat before it reaches the heated section of the bondle approxdmaty $0.76=(30 \mathrm{in}$.) belou the first spacer grid.

\subsubsection{Pipins}

The plping that interconnects the various heliun systen components as shows in Fige. 3.4, 3.10, and 3.11 will be ade of auscenitic stainless steel and will be desigued, constructed, and staped la sccordance with the rules for Class 2 Piping components in Section III of the ASWE

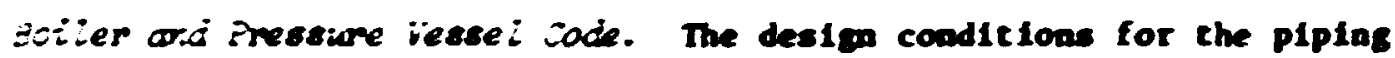
will be $11.72 \mathrm{rPa}$ (170C paig) and $399^{\circ} \mathrm{C}\left(750^{\circ} \mathrm{F}\right)$ except for the incercosnecting ru between the test wasel and $\mathrm{ax}-1$, for which the ceipercure w11 be $593^{\circ} \mathrm{C}\left(1100^{\circ} \mathrm{F}\right)$. An all-velded pipiag design vill be favored tor the CFTL.

The piplas will be sized to anfare velocity head friccion loss as wuch as practical, and the piplag runs will be designed to provide the upatrean and downetrean iengths that pood design practice requite for flor mesurement devices. 
There are three side nozzles welded to the vessel: the inlet nozzle located wear the top flange, which carries coolant heliun to the test buadle to rewore buadle beat, the atterperation wozzle, which carries coolant bellu to a pach parallel to the buadle pach to cool the test vessel presscte boundaries, and the outlet nozzle located wear the botton flange, which carries all the coolent belfin out of the test vessel. The vessel exterior will be insulated to reduce test bundle heat losses and reduce the radial temperature gradient in the pressure bowadary valls.

The inside dinater of the test vessel vill be large enough to sccomodate fuel test budies of $19,37,61$, and 91 simalators, a fullsize blanket asenly of 127 simalacors, and control rod cest buadle of 54 sibalators. In addition to the rod buedles, space shall be allowed for a cheral barrier installed around the buadles as well as an manlus between the thernal barrier and the test vessel, which wil be a flow path for the attemperation or bypass flow. The thermal bartier and attenperation flow will be designed to alntaln the pressure boundary below $427^{\circ} \mathrm{C}\left(000^{\circ} \mathrm{F}\right)$. The vessel pressure retaining boundary will be destgred for $11.72 \mathrm{rea}(1700 \mathrm{psia})$ and $427^{\circ} \mathrm{C}\left(800^{\circ} \mathrm{F}\right)$ and constructed and staned in accordace with the rules for class 2 composents, Section III, of the ASRE Boiler and Presenare Veseel Code. An inlet plemu will be designed at the cop of vessel to asure obtaining fully developed flow before the cooleat helim reaches the beated zose of the test bundle. An outlet plenu or axing chaber will be designed at the botton of the cest veseel downetrean of the buadle outlet to mx the bundle and attenperation helio flows before the coolant leaves the test vessel.

The interior of the test vessel at the outlet plenu will be ingulated to protect the high-tenperature heliu flow.

The simulator will extend upuard through the vessel inlet pleave and through the top blind flange, which will also serve as a tubesheet. Individual simulators w11 be joined to the pressure boundary by use of trepanaed ridges on the top surface of the cubecheet to which the heater sheath wll be electron-bean ielded. 
At the present tie conceptual layouts of the test vessel are beir 3 ade. The present design of the cylindrical portion of the vessel is a 0.25- (10-in.) sched 120 stainless steel pipe, wich appears to be large enough to accomadate all bundles to be cested. The total length of the test vessel, top flange to botton fiange, will be 3.30 to $3.81=$ (130-159 in.).

Several concepts of the outlist wixing chaber are still being evaluated. Two such concept: are: a baffled arrangenent dounstreas of the test bundle exit, and a perforated can between the two flow passages, which would allow the attemperation flow to be injected at relatively high velocity into the test bundle outlet flow. The inlet pleau is presently a woluse containing the top portion of che sibulator fron the top flange tubesheet down to the first spacer grid in the lover portion of the buadle, refarred to as the test section because it is the test simlation of a portion of 2 GarR core element. Studies are under way to deternice if this design will allow the heliu flow to become fully established as in an actual core element before it reaches the heated section of the tundle approxdately $0.76=(30 \mathrm{ia.})$ belos the first spacer grid.

\subsubsection{Piping}

The piping that interconnects the various heliw systen components as shown in Figs. 3.4, 3.10, and 3.11 wil: be mde of austenitic stataless steel and will be designed, construcied, and staped in accordance with the rules for Class 2 Piping Components in Section III of the ADVE zoiter ari Pressure Vesse $i$ Code. The design conditions for the piping will be $11.72 \mathrm{MPa}(1700 \mathrm{psig})$ and $399^{\circ} \mathrm{C}\left(750^{\circ} \mathrm{F}\right)$ except for the interconnecting rum between the test vessel and $\mathrm{kX}-1$, for which the taperature will be $593^{\circ} \mathrm{C}\left(1100^{\circ} \mathrm{F}\right)$. An all-welded piping design will be favcred for the CFTL.

The piping will be sized to anialze velocity head friction loss as muct as practical, and the piping runs will be designed to provide the upstrean and dowstrean lengths that good design practice require for flou seasurement devices. 


\subsubsection{Loop Pressure Drop Analysis}

Pressure drop losses around the helium system were calculated from the CFTL flow parameters of $30 \mathrm{~g} / \mathrm{sec}(240 \mathrm{lb} / \mathrm{hr})$ per simulator through the test section, $3.17 \mathrm{~kg} / \mathrm{sec}(7 \mathrm{lb} / \mathrm{sec})$ total maximu flow through the circulators, circulator outlet helium conditions of $343^{\circ} \mathrm{C}\left(650^{\circ} \mathrm{F}\right)$ and $8.96 \mathrm{MPa}$ (1300 psia). Loop components that were analyzed on the basis of helium conditions existing at that location included the test section (consisting of that portion of the test bundle from the top spacer grid to the bottom spacer grid), test vessel inlet plenum, outlet or mixing plenum, flow control valve, floweters, large heat exchanger, fullflow filcer, and system piping.

The test section losses were specified by $G A$ to be a maxinum of $278 \mathrm{kPa}$ (40.4 psi) for all flow conditions of the CFTL operating enveiope. This number is derivad from the premise that the reference GCFR iesign is able to allocate this amount of the circulator head to the reactor core pressure drop. Since the CFTh operating envelope includes a mch higher flow rate $[30 \mathrm{~g} / \mathrm{sec}(240 \mathrm{lb} / \mathrm{hr})$ per simulato:] than the reference GCFR nominal flow $(23 \mathrm{~g} / \mathrm{sec}(186 \mathrm{lb} / \mathrm{hr})$ per rod, the flow cross-sectional area in the CFIL bundle would have to be increased to accomodate the increased flow to maintain the same pressure drop acrcss the rod bundle.

The coolant helfum flow path into the CFTL bundle simulators differs from the parallel entry into a GCFR core element in that the helfum enters perpendicular to the simulators and must flow radially into the simulator lattice and turn fir order to take the proper parallel flow direction before reaching the top spacer grid. Therefore, it was necessary to calculate the inlet plenum pressure $10 s 8$ based on this ifference. The plenum resistance is due basically to three sources: expansion from the inlet nozzle, $90^{\circ}$ change in direction, and friction frow radial flow through the rod assembly. Total losses were calculated to be $18.6 \mathrm{kPa}(2.7 \mathrm{psi})$ for the CFTL conditions.

The test vessel outlet plenum is a)so different from the GCFR design because its purpose is to promote mixing both the test section and the attemperation coolant streams. This is necessary because of the high temperature of the test section coolant flow, especially 
during the apfroach-to-cladoing-nelting experiment, undercooling, etc. The pressure drop across the plenum depends on how the streans are aixed: in geveral, the better the aixing the larger the pressure loss. Calculations were basec on a concept that would provide the best aixing, therefore the greater $\Delta P$, with the resulting pressure drop of $46.8 \mathrm{kPa}$ (6.8 psij. Any other practical mixing concept should produce a $\triangle P$ less than that stated above but would be somewhat less efficient in aixing the heliun flows. In addition to the axing action, further protection of the test vessel from high-tenperature heliun is obtained by insulating the pressure-retaining boundary of the outlet plenun from the helium.

The flow control value located in the primary helfun flow upstrean of the test section will add resistance to the flow of helfur, depending on the trie installed in the valve. The aximun $\triangle P$ of this coaponent has been estimated to be $62 \mathrm{kPa}(9 \mathrm{psi})$ for the range of flow conditions to be experienced in the CFIL.

Presently two flometer stations are located in the primary or main helium flow path, one upstream and one downstrean of the attexperation flow cee. For the pressure calculation each station was assumed to consist of one venturi floweter and one target floweter, whose flow resistances are $7 \mathrm{kPa}(1 \mathrm{psi})$ and $3.5 \mathrm{kPa}(0.5 \mathrm{psi})$, respectively. Theiefore, the total floweter $\Delta P$ 1s, based on present design, $21 \mathrm{kPa}$ (3 psi). Ultrasonic floweters are presently being evaluated, and if we find that such units could be used in the CFTL, then the 21 kFa ( 3 psI) resistance would be essentially ellminated.

The 4.7-k heat exchanger is a helium-to-air heat exchanger and as such requires large heat transfer area to reject its head load. For scoping and preliadnary design, a heat exchanger was designed to provide the requirel surface area, coolant velocity, etc. This theoretical design was then used to calculate a base pressure drop, which was Increased to $69 \mathrm{kPa}$ (10 psi) to cover the maximum drop expected with a realistic exchanger design.

Information on the full-flow filter located downstream of the 4.7-M heat excinanger has primarily been from filter manufacturers. 
Present design specifies $15 \mu$ absoiute as the filtration requirement. Prelininary data indicate the pressure drop across this unit would be a maximun of $34.5 \mathrm{kPa}$ ( $5 \mathrm{psi}$ ). The filter's primary purpose is to protect the helium circulaturs from particles that night be generated in the test section, especially during cladding melting experiments. However, the circulators presently being considered way be capable of ingesting particles of larger size without damage to bearing surfaces. If such is the case, then it may be rossible to change to a coarser filter having a reduced pressure drop and less flow resistance.

The final component is the systen piping. Present design has all piping to be 0.15 ( 6 in.), sched 80 except for the section connecting the test vessel outlet to the heat exchanger inlet, which is $0.15 \mathrm{~m}$ (6 in.) sched 120 . The proposed layout of the loop would result in a total pipe length of approximately $30 \mathrm{~m}$ (100 ft). Total pressure drop for the piping was calculated to be $17.2 \mathrm{kPa}(2.5 \mathrm{psi})$.

The sum of the pressure drops of all the CFTL components based on the assumptions noted above is $547 \mathrm{kPa}(79.4 \mathrm{psi})$ for the $8.96 \mathrm{MPa}$ ( $1300 \mathrm{psia}), 343^{\circ} \mathrm{C}\left(650^{\circ} \mathrm{F}\right), 3.17 \mathrm{~kg} / \mathrm{sec}(7 \mathrm{lb} / \mathrm{sec}) \mathrm{flow}$ conditions. The head rise requirement for the circulators is then $547 \mathrm{kPa}$ (79.4 psi) or $7976 \mathrm{~m}(26,170 \mathrm{ft})$ based on circulator out let helium conditions of 8.96 MPa (1300 psia) and $343^{\circ} \mathrm{C}\left(650^{\circ} \mathrm{F}\right)$. A corresponding analysis of the system was made for the $10.34 \mathrm{MPa}(1500 \mathrm{psia}), 343^{\circ} \mathrm{C}\left(650^{\circ} \mathrm{F}\right)$ based on the same flow rate. The head requirement for these conditions is $589 \mathrm{kPa}(85.5 \mathrm{psi})$ or $7443 \mathrm{~m}(24,420 \mathrm{ft})$.

\subsection{HELIUM CIRCULATORS - H. C. Young}

Helium circulator activity was started in May 1974 with the preparation of a draft specification for a centrifugal machine supported on gasfilm-lubricated bearings. Upon the request of AEC-RRD, the specification was broadened to include all types of gas-circulating machiriery, and the UCND Purchasing Division made a preliminary inquiry in July 1974 to 17 circulator manufactucers. Three manufacturers responded positively and all opted for a centrifugal machine supported on gas-lubricated bearings. A formal specification for a centrifugal. circulator supported on 
gas-film-lubricated bearings was prepared, and a request for proposal was sent to the three mufacturers. All three responded with decailed proposals and were visited by an evaluation team in aid-April 1975. A cost-plus-fixed-fee contract for design, production, and testing of a prototype circulator was awarded to Hechanical Technology, Inc., of Lathan, New York, in June 1975. Upon completion of the prototype circulator, a fixed-price contract will be negotiated for the three production units for the CFTL. MI's original schedule indicated delivery of the production circulators would be in October 1978; however, this delivery date could be reduced to approximtely February 1978 if additionai funding for long lead items for the production circulators were provided by ERDA in early fiscal 1976 .

\subsubsection{Prelininary Inquiry}

The general steps in the circulator procurement and the completion dates are listed in Table 3.2.

Specification $4-11590-R B-001-S-0$ for hellid irculators for the CFTL was prepared, reviewed, and approved by project personnel by June 27, 1974. This specification was based on a hermetically sealed centrifugal machine in which the rotary assembly is supported on gasfilw-lubricated bearings (gas bearings).

On the basis of a preliminary review of the specification, the AEC-RRD requested changing the base to include centrifugal, axial, reciprocating, and diaphragm circulators in order to invite manufacturers of all types of circulators to particlpate in the bidding. Accordingly, preliminary specification, M-11590-RB-002-S-0, which was completed on July 24, 1974, permitted the helium flow requirements to be supplied with either a single-stage, a msltistage, or multiple single stage centrifugal, axial flow, reciprocating, or diaphragm circulators. Requirements were specified for helium purity, limit on amplitude and frequency of flow pulsations, helium leak rate to the atwosphere, and operational rellability during rapid depressurization of the CFTL and during an inlet temperature transient of $28^{\circ} \mathrm{C} / \mathrm{sec}\left(50^{\circ} \mathrm{F} / \mathrm{sec}\right)$ for $1 \mathrm{sec}$. 
Table 3.2. Steps In Placing a CPFF-Type Contract for Heliun Circulators for Phases I and II

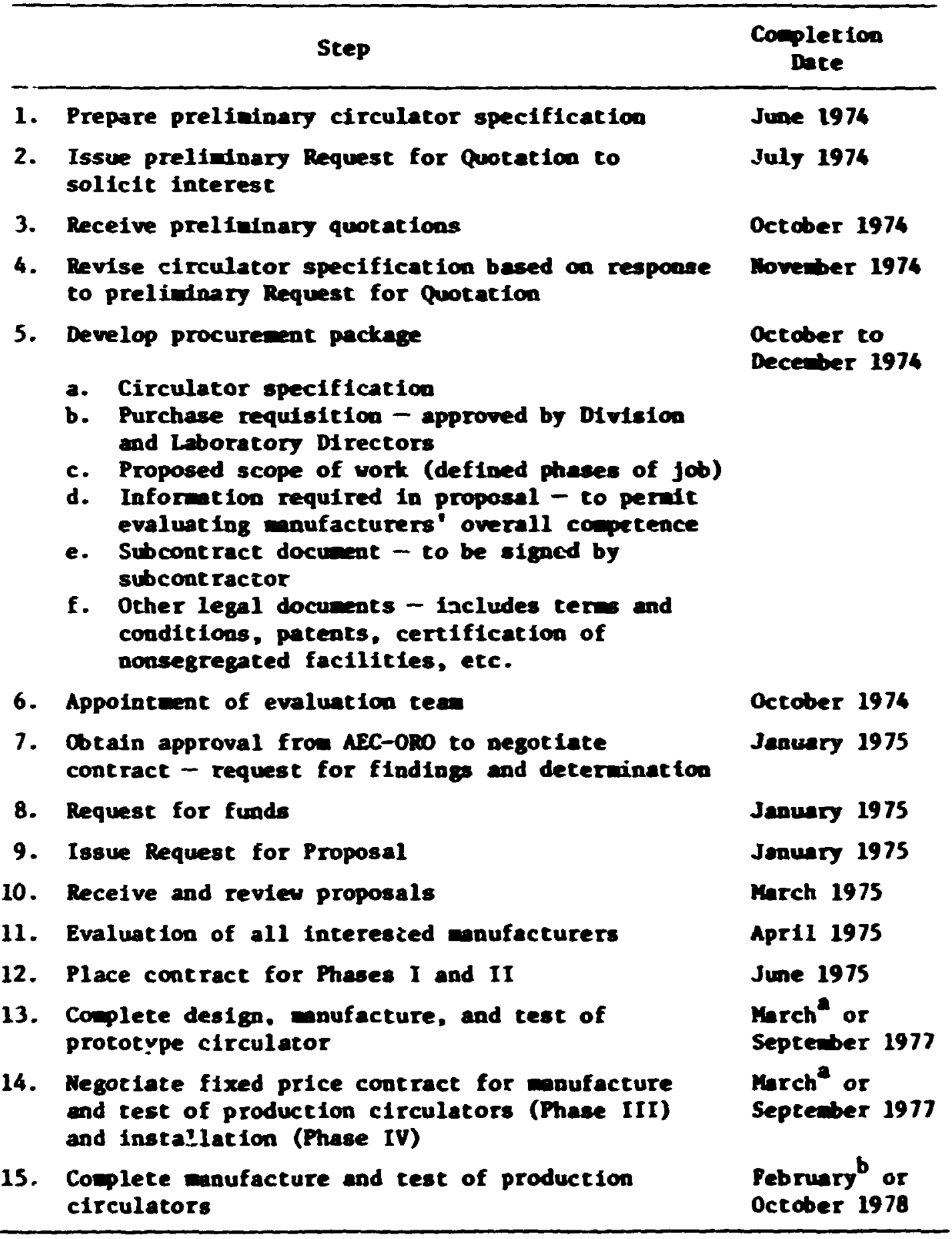

Eerly date contingent on authorizing circulator supplier to start fabrication of pressure vessel early in Phase $I$.

bearly date contingent on additional funding for long-lead items for the production circulators being provided by ERDA early in fiscal 1976. 
Sone circulators were expected to require auxdliary equipant such as pulsation dapeners, filters, and additional beliue purffication capacity to remove impurities introduced by the circulator. Lar efficleaty circulators would require a larger and wre costly power supply and control.

A prelinianty request for quotation ua miled to potential suppliers on July 30, 1974, by the UCub-Purchasing Difiston to invite industry's interest in participating in the deaign, mafacture, and testing of beliu circulators for the CFI. Qwotations were originally to be supplied by Auguet 29, 1974; hovever; several potential suppliers requested additional cime, and quotations were accepted through afdOctober, 1974.

Of the 17 potential circulator suppliers, chree expreased definite interest in providing the circulators and all three proposed centrifugal mchines supported on gas bearing. Six well-known mafacturers of reciprocacing compressors and two well-known nanfacturers of diaphragm compressors declined to bid. Some of the firm that produce rectprocating. or diaphrage-type achines indicated that our application would be better provided with a centrifugal achine. The diaphragn conpressor maufacturers stated that the number of larce diaphraga compressors requited, plus tne equipment needed to dapen the flow pulsations to the required level. would mke their pricing nonconpetitive with the centrifugal ench fine.

One of the three incerested circulator maufacturers proposed four centrifugal circulators arranged in series. A second manfacturer proposed ather four circulators arranged in saries or series-parallel. In each case, the chofce of four circulators was besed on the avallability of basic motor destips of the type and power required.

Bepresentatives of the third eirculator anufacturer visited the uchD Purchasing Itvision to discuss their proposed coacepte with project persoanel. Theit recomanded cholce was less conventional, with the cotor wouted outalde the circulator preasure-retaining boundery and a metic coupling exployed to drive the motor through a ceranic cylinder that is part of the preasure boundary of the circulator vessel. 
This manfacturer's second cholce has the drive motor inside the pressure-retaining boundary. It is sinflar to the other two manfacturers' concepts, except that two inpellers are counted on a single shaft.

Based on informition received with the prelininary quotations (i.e., that four circulators were required rather than three as anticipated) and the amovacenent at the October CFTL Information Heeting that project funding was reduced, studies were conducted to find ways of reducing the costa of the efrculators. A review of the pressure losses in the CFTL piping, composents, and test section indicated that the original assuption of basing pressure drop on the $10.34 \mathrm{rPa}$ (1500 psia) condition yielded conservative, large values. Calculations of pressure drops in the CFTL based on the $8.96 \mathrm{PPa}(1300 \mathrm{psia})$ condition indicated that three rather than four circulators in series should provide the GCFR requirements and also provide some margin for cesting advanced core destgns having increased pressure drop requirements. Also, in the interest of reducing circulators costs, each of the three interested moufacturers was asked about the possibility of changing from a variable frequency to a fixed-frequency pover supply for the circulator drtve wotors and an estimate of the cost saving that aight be realized by changing from the requi rements of Section III, Ciass 2 , to those of Section VIII, Division 1, of the ASIE Code as applied to the circulator pressure-retaining boundary. Because of very high starting currents, a fired-frequency power supply was not recomeaded. The estimated saving in changing code requirements was about $5 \%$.

The upshot of the prelininary inquiry was to return to the gas bearing circulator. The original gas bearing circulator specification was revised, reviewed, and approved by project personnel. The aajor revisions included: basinf the circulator head requirement on the 8.96 MPa (1300 psia) GCFR condition; as updating of reference to the code to agree with the latest issue of Section III of the ASME Boiler and Pressure Vesscl Code; change in the cumulative helium leakage across the pressure retaining boundary in $10^{-8}$ to $10^{-7}$ std al/sec with the 
c1rculator evacuated; and a relamtion in the specified madmo operating speed fron 110 to 1002 of design speed. Sone principal circulator requirements are listed in Iable 3.3.

Table 3.3. Sone Principal Circulator Requirenents

\begin{tabular}{|c|c|}
\hline Design Iten & Dequired Falue \\
\hline Preasure, MPa (psi) & $11.7(1700)$ \\
\hline Tenperature, ${ }^{\circ} \mathrm{C}\left({ }^{\circ} \mathrm{F}\right)$ & $370(700)$ \\
\hline Service $11 \mathrm{fe}$, years & 10 \\
\hline Fow rate, $\mathrm{kg} / \mathrm{sec}(1 \mathrm{~b} / \mathrm{sec})$ & $3.2(7.0)$ \\
\hline $\begin{array}{l}\text { Bead required, } \mathrm{kJ} / \mathrm{kg} \text { (ft-1b/1b) } \\
\text { for } 8.94 \mathrm{~mA}(1300 \mathrm{psi}) \text { outlet pressure } \\
\text { for } 10.34 \mathrm{LPa}(1500 \mathrm{psi})\end{array}$ & $\begin{array}{ll}78.2 & (26,170) \\
73.0 & (24.420)\end{array}$ \\
\hline Out let helius temperature, "C $\left({ }^{\circ} \mathrm{F}\right)$ & $343 \pm 4(650 \pm 10)$ \\
\hline
\end{tabular}

The Purchasing Division proposed and project personnel sgreed that a four-phase procurement cctivity was indicated. A cost-plus-fixetfee contract was proposed for the design and developmeat phases. A fixed-price contract vould then be negotiated for Phase III production of the vorking circulscors.

Approval by acc-0Bo vas obtained for the procurenent activity, and an evaluation tesn was appointed by the Purchasing Division to evaluace all the proposais produced by this activity and te select the nost prodsing.

\subsubsection{Requese for Proposal}

On January 30, 1975, request for proposal T09061-78 was sent to:

Hechanical Technology, Inc. - Luthan, New York

Nowald-Tirbo, Inc. - Lachan, New York

Shaker Research (tean)

AlResearch Manufacturing Comany - Torrance, Califomia

Hortington Sales Compan; - At lanta, Georgla 
The bid closint date was set for March 4, 1975. Horthington declined to bid. Because of the difficulty in finding in U.S. Industry a developed drive cotor, Alresench requested a five-reek extension of the bid period to April 7, 1975. AlResearch was notified that its proposal would be evalunted on the exits of its techntical concept and on the capability and ccuitient of their copany to produce the circulators. Allesenrch then requested, and uas granted, a twoweek extension to the bid perioc. The other prospective bidders were notified of the chrnge.

Aillesearch indicated that it did not possess an ASHE Muclear Code (x) starp and requested advice on the procedure for design and fabrication of the pressure-retaining boundary. Because none of the three tidders possessed the (X) stan, all three were advised of three options available to then: (1) The bidder cculd apply to ASrE to obtain a certificate of authorization to perfore the design; then he could subcontract fabrication to a mufacturer having en $X$ stap. This process would requite considerable tine. (2) The bidder could subcontract both design and canufacture to a company that has AStE Code (N) stasp. (3) Bidder could subcontract design co conpany holding certificate of authorization from ASTE to design vessel; then Bidder could authortze that comany to subcontract fabrication to a third company having a Sect. III, Class 2 , stam.

\subsubsection{Proposal Evaluat In}

Proposais vere received from all three bidders on the due date, March 18, 1975. Copies of each proposal were sent to nexbers of the evaluation tean and certain Laboratory specialists for revieu convents. Table 3.4 presents an approximate schedule for the evaluation activities.

The proposal reviewers met on Apri1 8, 1975, to develop a set of questions to ask the bidders, and these questions plus a pro;osed agenda for on-site evaluation meetings were sent to each of the bidders. Rating sheets to evalure each bidder had been developed earlier.

The evaluation tean visited MI and Norwalk-Turbo for two days each, April 14 to 18, 1975, AlResearch on April 21 and 22, and A1Research's pressure vessel subcontractor on April 23. During the evaluation visit, 
Table 3.4. Approxdmete Schedule for Evaluation Actirities"

\begin{tabular}{|c|c|}
\hline Action & Date \\
\hline $\begin{array}{l}\text { Transint copies of proposals to reviewers } \\
\text { Reviewers provide written comente }\end{array}$ & $\begin{array}{l}\text { Friday, Yarch 21, } 1975 \\
\text { Thursainy, Apre1 3, } 1975\end{array}$ \\
\hline Reviewers neet & $\begin{array}{l}\text { 8:30 en, Tuesday, April } \\
\text { 8, } 1975\end{array}$ \\
\hline $\begin{array}{l}\text { Purchasing to alert bidders of visit by } \\
\text { Evaluntion Teas }\end{array}$ & $\begin{array}{l}\text { No later than April } 8 \text {, } \\
\text { 1975, for April } 14-18 \\
\text { Jisits }\end{array}$ \\
\hline Consolldate review coments & Apri1 9-11 \\
\hline Evaluation Tean visit to bidders & April 16-18 \\
\hline Evaluation Tea prepares repert & April 21-25 \\
\hline $\begin{array}{l}\text { Evaluation Tean subaits report and } \\
\text { recolmendation for bidder selection } \\
\text { to General Furchasing Agent }\end{array}$ & April 28 \\
\hline $\begin{array}{l}\text { Ceneral Purchasing Agent request peraission } \\
\text { from ERA-0w0 to place contract }\end{array}$ & wiay $1,1975^{b}$ \\
\hline ORO granes perntesion & Iting $6,1975^{b}$ \\
\hline Place contract with successful bidder & UFay 9, $1975^{b}$ \\
\hline
\end{tabular}

Evaluation Teas: H. C. Hebb, Chatrenn, Purchasing Division; A. Hopson, Purchasing Division; D. W. Burton, K-25; A. G. Grindell, onri; J. R. HeGuffey, ORar; H. C. Young, ORrL.

bThese activitics vere delayed because of legal questions relating to licensing fees for a motor designed for an earlier government project.

each bidder was informed that the specified head developed by the circulators was to be increased by approximately 15\%. The change in head was deternined to be feasible and within the capability of each bidder's proposed concept. The Evaluation Tean rated each bidder as soon as practical after each weeting.

The fivaluation Tean subnitted its technisal report and recomendation on Apri1 30, 1975, to the UCMD Purchasing Division recomending that Mechanical Technology, Inc. (MTI) be warced a CPFF contract for the design (Phase I) and the developnent (Phase II) or the protstype of the CFTL helfu circulators, with the further reguitement that MI produce 
three working circulators (Phase III) for the CFTL in a follow-on fixed-price purchasing contract to be negotiated at the conpletion of the prototype phase. The prototyplc circulatiar wculd then serve as a spare.

A formal evaluation report was prepared, sfyed by all nembers of the Evaluation Tean, ad subatited to the Geacral jurchasing Agent. vasd Purchasing Division, on May 2, 1975.

\subsubsection{Contractural Berptiations}

A requited on-site prearard audit of $\mathrm{XII}$ uas completed, and $\mathrm{MI}$ was informed by celegran that it had been selected.

The circulator specification was revised to fnclude the nev head requirements. In additior, at a result of discuss fons with the three bidders. the requitement that the bidder provide analysis to sesure that the circulator has the capability of sustaining a $28^{\circ} \mathrm{C} / \mathrm{sec}\left(50^{\circ} \mathrm{F} / \mathrm{ser}\right.$ decrease in inlet helium tesperature for $1 \mathrm{sec}$ w thout damage to the circulator was added to the specification, and the requirement that this capability be proven experimentally was deleted from the specificaticn.

The revised specification was forwarded to $\mathrm{MII}$, and the UCAD Purchasing Division then began negotiating the actual contract vith ITI, considerirs the revised specification, terns and conditions, patents and licensing of the drive motor design from General Electric Company. fee, and a requeat by ERDA to record test data on agnetic tape. After adjidicating the licensing agreement, the contract was signer for VCid on June 4, 1975, signed by MII on June 6, 1975, and approved 2 , ERDA-0nO on June 17, 1975.

The schedule, Table 3.4. was fairly well adhered to througi the submission of the evaluation cean report on April 30, However, substantially longer tiace than estisated to negotiate a licensinj agreement for the drive wotors resulted in contract approval four wrek- later than estianted.

\subsubsection{Description of Proposed Circulator Concspes}

All three bidders for the heliun circulaturn, AlResearch, Mechaileal Technology, Inc. (MI), and Nomalk-Turbo, Inc., proposed centrifigal 
achines supported on belifu-lubricated self-act ing journal and onemay chruse beariags. Each of the two vertically oriented AfResearch circulators uses a $149 \mathrm{kH}$ (200 hp) electric cotor and a desigo speed of 23.750 tpe. The MI coacept shown in Fig. 3.14 requires three circu lators in series, each with 2180 -hp $(134 \mathrm{~kW})$ drive motor. The design speed is 23,500 rpe and the shaft bas a near horizontal ortentation. The Xorualk-Turbo concept is very sinilar to the $\mathrm{kT}$ unt and requires four circulators in series, each vith $93.4 \mathrm{kd}$ (125 hp) drive votor. NorwalkTurbo chose a desion speed of $18,000 \mathrm{rpm}$.

\subsubsection{Schedule Ieprovenent}

The origial schedules Indicated that each biddai would require approxiately $3 y$ watins after statt of the coatract to corplete Fhase IV; that is, approval of final installation of the production circulators in the CFTL.

We vere requested by EDOA and Ceperal Atonic to deternibe the feasibility of inproving the circulator schedule by to 12 wonths over the 39 math schedule.

The successful bidder, Mechanical Technology, Inc., stated that the overall schedule can be reduced fron 39 to 30 wonths provided ve approve within three waths after the start of Phase I design the purchase of critical $100 \mathrm{~g}$ delivery item for the thrte vorking circulators that are to be produced at fixed price in Phase III of the contract, and provided ond will lend inI a variable frequency power supply within 12 months of start of Phase I design. The pover supply will be used by MII for performance testing of the prototype Phase II circulator and the three Phase III working circulators. Then it will be returned to opar and installed at the CFTL site.

The long-lead item for Phase III are the prescure vessel material, iabrication of the pressure vessels, Impeller forgings, and drive mosors.

To shorten the overall schedule for Phases I, II, and III of the hellum circulator procurement from 39 wonchs to 30 months would require authorizing the expenditure early in Phase I of $\$ 136,000$ of Phase III funding by KTI plus $\$ 37,000$ for procurement of a variable-frequency power supply by oph. 
anthines supported on belfu-lubricated self-acting journal and one-way chrust bearings. Each of the two vertically orieated AlResearch circulators uses a $149 \mathrm{kl}(200 \mathrm{hp})$ electric wior and desiga speed of 23,750 tpa. The itI concept shown in Fig- 3.14 requires thrce circulators in series, each with 2180 -hp $(134 \mathrm{kH})$ drive otor. The design speed is 23,500 rpa and the shaft has a near horizontal orfentation. The Monvalk-Turbo concept is very siailar to the arI unit and requires four circulators in series, each with $93.4 \mathrm{kH}$ (125 hp) drive ocor. DorwalkTurbo chose a desiga speed of 18,000 rpe.

\subsubsection{Schedule Inprovenenc}

The original schedules indicated that each bidder unuld requite approxdmately 39 waths after start of the contract to couplete Phase IV; that is, approval of finsl installation of the production circulators in the CFTL.

We vere requested by EFOA and General Atomic to dezernine the feastbility of inproving the circulator schedule by 6 to 12 months over the 39 month schedule.

The successful bidder, Hechanical Technology, Inc., stated that the overall schedule can be reduced fron 39 to 30 wonths provided ve approve within three woths after the start of Phase I design the purchase of critical long delivery item for the three working circulators that are to be produced at fixed price in thase III of the contract, and provided ORIL will lend MI a variable frequency power supply within 12 wonths of scart of Phase I design. The power supply ulll be used by MII for performance testing of che prototype Phase II circulator and the thrce Phase III working circulators. Then it will be returned to ORIL and installed at the CFTL site.

The long-lead lcess for Phase III are the pressure vessel material, fabrtcation of the pressure vessels, inpeller forgings, and drive notors.

To shorten the overall schedule for Phases I, II, and III of the heliue circulator procurenent from 39 wonthe to 30 wonths would require authorizing the expendicure early in Phase I of $\$ 136,000$ of Phase III funding by MI plus $\$ 3 i, 000$ for procuremen.t of a variabje-frequency power supply by ORon. 


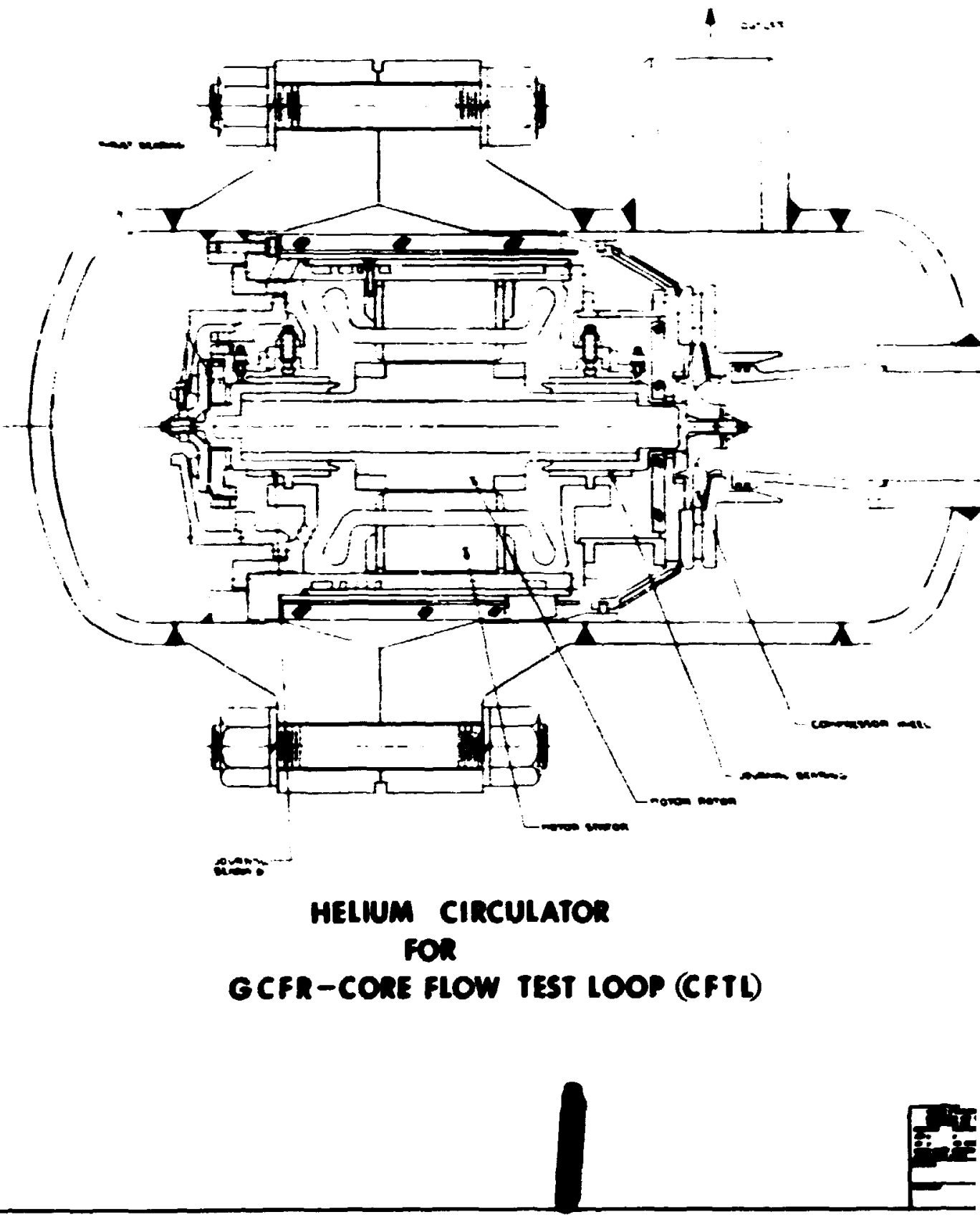

F1g. 3.14. Hellum Circulacor for GCFR Core Flow Test Loop, CFTL. 


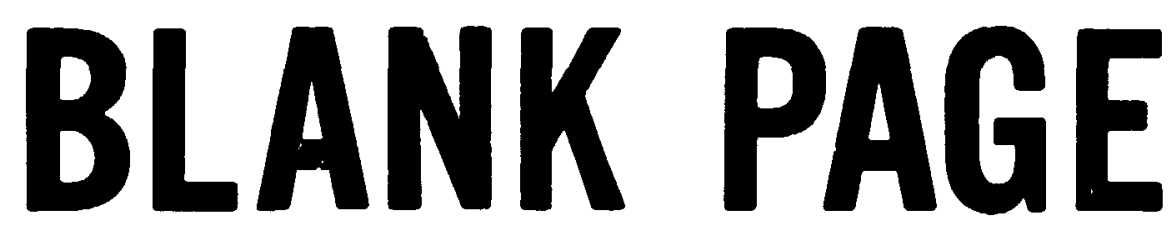


The additional f'unding required early in FY 1976 would be:

$$
\begin{array}{lr}
3 \text { circulator drive motors } & \$ 24,000 \\
3 \text { pressure vessels (material and fabrication) } & 111,000 \\
\text { inpeller forgings } & 1,000 \\
1 \text { variable-frequency power supply } & 37,000 \\
\hline & \$ 173,000
\end{array}
$$

Funds for the activities in Phases I and II are already available in the FY 1976 "A" budget.

Bechanical Technology, Inc.. will propose approximately 2.5 months after recelpt of the order for Phases I and II the detalled requirements for the critical long lead items that pernit the schedule inprovement.

We could authorize MI to order only the pressure vessel material for Phase III; however, MI suggests that some cost is saved by ordering fabrication of all four pressure vessels simultaneously. They indicate there is essentially no risk that prototype tests would cause a change in the pressure vessel design.

A request for additional funding will be issued by ORML inediately after ERDA-ORO approves the contract with MI.

3.5 HEATER DEVELOPALAT FOR GCFR FUEL. PIN SIMULATORS - v. L. Clark and R. H. HcCulloch

Request for design of a GCFR fuel pin simulator (FPS) was received in January of 1974. This report covers the subsequent design, mterials selection, FPS specification, quality assurance, and procurement activities needed to develop the fuel pin simulator. Two other projects directly related to the GCFR fuel pin simulators vere active in this report period. These are: the design and procurement of a mockup GCFR fuel pin simlator, which will be used to evaluate thermocouple nolse and accuracy to select the optian thermocouple design, and the modification of the L.TFBR FPS Test Facility to enable testing of the larger diseter GCFR FPS.

Because of the sinilarities of the FPS, the previous development at ORI of the electrical hesters for the LapBR fuel pin simulators provided a significant base for wost of the efforts in this work. Wherever practical (and in essence this was so throughout this tie period), all 
developments of GCFR fuel pin simulator are coordinated with the continuing efforts in improving the LMBBR fuel pin simulators. To the extent feastble, this was also true for the opr effort in PuR fuel simlators for the ilow Down Heac Transfer and Hultirod Burst Test prograns.

\subsubsection{Fuel Pin Simulator Design}

The prelininary design of this FPS was based on the successful design being used for the LFPR Category II FPS, as show in Fig- 3.15. The larger diameter of the GCFR fuel fin provides sufficient crosssectional area for the inclusion of a central electrical conductor in a coaxial configuration with the other electrical conductor (and the heating element). The selected design for the FPS prototype is show in F18. 3.7 (p. 88).

This design was discussed in detail in meetings with $G$ and EROA-RRD persoanel as well as with each of the potential heater vendors. Fabrication detalls were worked out, and appropriate design corrections were ade. Some potentially difficult assedly problems remin, but each of the six potential vendors is avare of these areas and is working out his own solution.

The FPS is designed to accceodace a multiple number of internal therwocouples for seasuring the terperature of the internal surface of the sheath. The measuring furction ay be grounded, insulated, or Intrinsic; the type will be deternined on the basis of tests that will be conducted on wockup FPSs are covered in Sect. 3.5.6. The thernocouple will be ISA type $K$ sheathed, 0.51 or 0.38 ob (0.020 or 0.015 in.). These thernocouples should be capable of accurate measurements up in approxtentely $816^{\circ} \mathrm{C}\left(1500^{\circ} \mathrm{F}\right)$ and reduced accuracy at higher temperatures.

The FPS lead design is based upon one side of the power supply being at ground potential (thru suftable grounding resistors) and with that side of the power supply connected to the outer (tubular) lead-in conductor. Thus the insulation thickness for this tubular lead-in conductor can be reduced to a very thin but controlled layer.

The FPS lead-in conductor configuration is based on a relatively short external length [less than 25 ( 1 in.)] of the outer tubular lead-in conductor before its connection to an adequately cooled bus. 

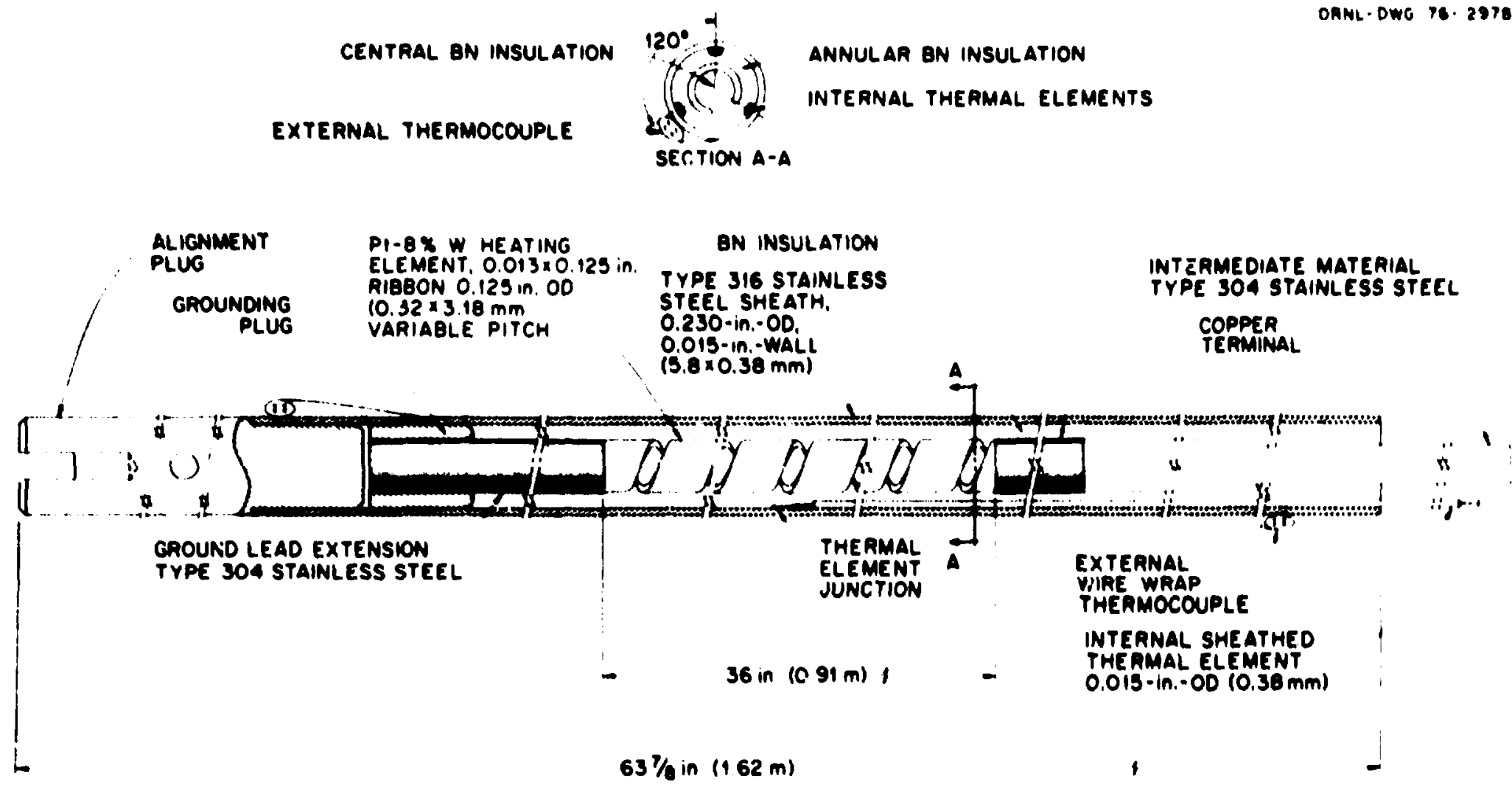

718. 3.15. LMPR Category II Bundle 6 Fuel PIn Stmulator. 
Further analysis will be ade as required to ensure against overheating of eicher lead-in conductor extemal to the heater sheath.

The heater design is based on $45 \mathrm{kH}$ at $250 \mathrm{~V}$ and $180 \mathrm{~A}$ (approximately), but variations can be accomodated by changing the heating element ribbon design. The heating element ribbon thickness was selected to be 0.25 ( $0.010 \mathrm{in.}$ ) to provide suitable electrical clearances for the BN insulation without being too fragile. Previous experience vith heating elements of this approximate size was a further contributing factor.

\subsubsection{Materials Selection}

This development included investigation and selection of materials for the heating element, the two coaxial heater lead-in conductors, the interwediate materials (between the heater lead-in conductors and the heating elewent), the heater sheath waterial, the grade and type of boron nitride (BN) Insulation, studies to determine the optimum BN density (and uniforaity), and the continuing development of cold-pressed tubular and rod preforms of $B N$.

\subsubsection{Heating Element Material}

On the basis of previous research for the LMFBR fuel pin simulators, the investipations into heating element material were limited primarily to three candidate materials:

1. Nichrowe $\mathrm{v}$, a heating element material consisting of $80 \% \mathrm{Ni}$ and $20 \% \mathrm{Cr}$, melts at approximately $1400^{\circ} \mathrm{C}\left(2550^{\circ} \mathrm{F}\right)$ and is essentially the industry standard for heating elements. This alloy has excellent fabrication qualities relative to forming, machining, ductility, weldability, brazeability, etc. It has a very low temperature coefficient of resistivity [less than $6 \%$ total from ambient to $1370^{\circ} \mathrm{C}\left(2400^{\circ} \mathrm{F}\right)$ ] and it is stable toward pure $B N$ up to its melting point. Known reactions with ispurities in previous grades of BN (and possibly with some present grades) occur primarily above $1260^{\circ} \mathrm{C}$ ( $\left(2300^{\circ} \mathrm{F}\right)$.

2. Kanthal $\mathrm{A}-1$, heating element material consisting of 1 ron, chromium, and aluminum, melts at approximately $1510^{\circ} \mathrm{C}\left(2750^{\circ} \mathrm{F}\right)$ and is used primarily for higher temperature requirements. Also, its lower cost leads to use 
In certain other applications. This material is mch ore difficult to work with as it is relatively brittle and, for all practical purposes, cannot be welded. Its tesperature coefficient of resistivity is very low (slightly lower than Nichrome v). It was specifically designed for use in oxidizing atwosphere, where the aluninu would be converted to aluninu oddde on the surface and provide an effective barrier against further oxidation. There are no known problens with compatility betueen and Kanthal A-1, but this has not been evaluated fully on a tineterperature basis. Other sinilar alloys like Hoskins 875 have also been considered.

3. The resistance alloy Pt 87 w (trade name Sigand Cohn Alloy 479) melts at $1760^{\circ} \mathrm{C}\left(3200^{\circ} \mathrm{F}\right)$ and is normally not considered as a heating element mterial. In the annealed state, it has reasonable forning and achining characteristics. It is easily veldable to merials of interest and is very comatible with candidate $B$ pouders. Other than high cost, the min objection to its use is its high temerature coefficient of resistivity compared with the other candidate materials (see Fig. 3.16). In the development of LAFBR fuel pin sfmiators, some research was performed to optinize the tungsten content and to ajd rhodiun as a third constituent, both for the prime purpose of lowering the ionperature coefficient of resistivity. The addition of wre tungsten results in an alloy that is so hard that noreal rolling and reduction techniques are ineffective. Linted funding has pernitted only a mininal research effort on the tertiary alloy, and this effort was primarily restricted to the alloy $\mathrm{Pt}-8 \mathrm{-W} W-26 \pi \mathrm{Ph}$.

Since the Nichrome $V$ melts at a temperature well above the calculated steady-state temperature for the heating element (see Fig- 3.17) and also above the calculated temperature for the heating element in the first transient tests, it has been selected as the initial heating element aterial. Also the weldability of Nichrome $V$ is of extrene importance because of the minimal tolerances permitted by tise heater design.

Subsequent test requirements, such as cladding relocation tests, will require the use of heating elewents having higher melting terperatures, and these will be evaluated as required. 

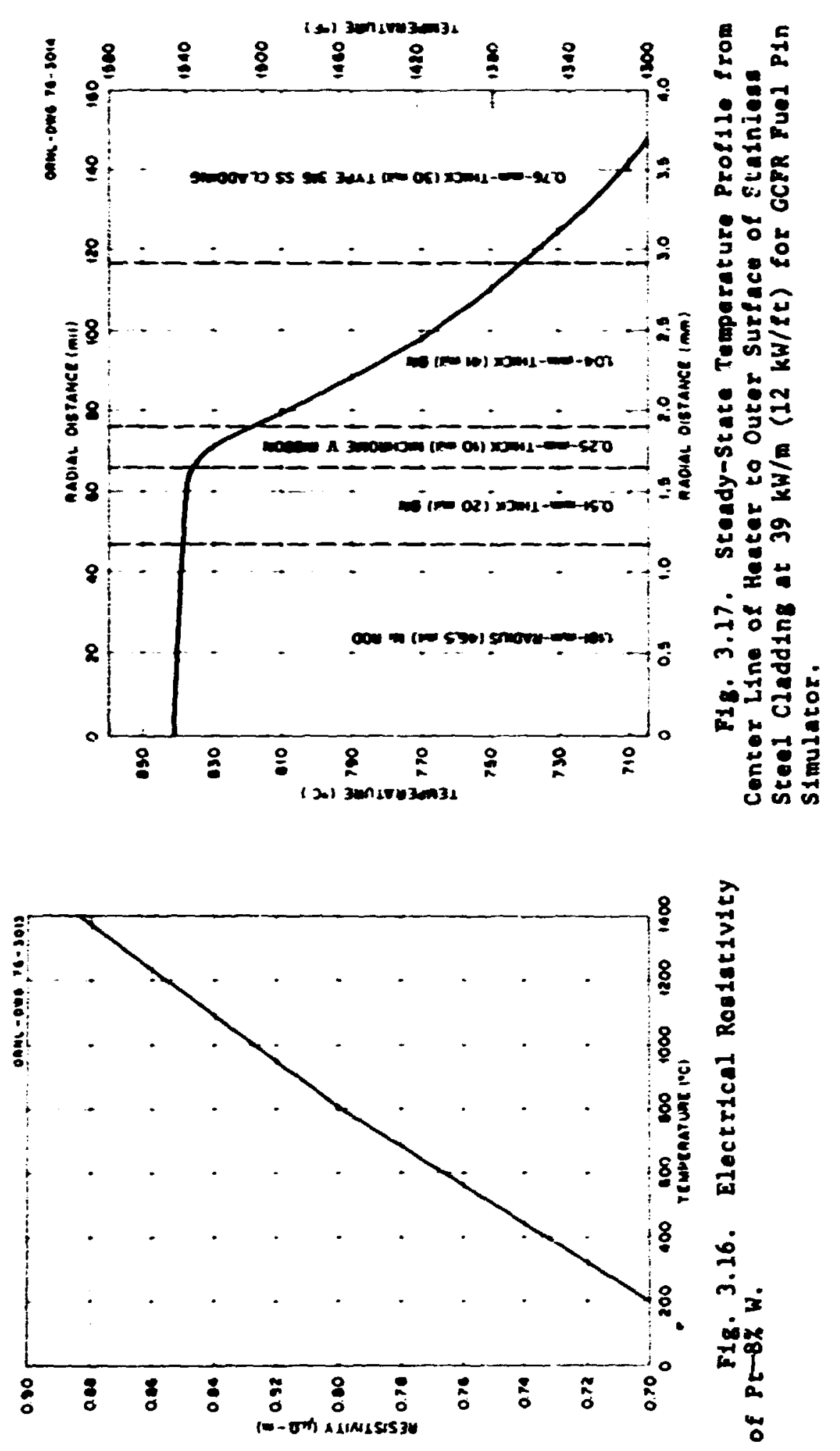


\subsubsection{Fuel Pin Simulator Lead-In Corductors}

The FPS lead-in conductors conduct the current to the heating element or to the internediate mterinl, in this case, without witing or othenise deteriorating, while generating a miniml anount of jeat. In the coaxial heater lead-in conductor arrangenent, the latter is of ext reve importance (see Sect. 3.5.1).

The ideal mterial would be silver, with its low resistivity and excelleat fabrication qualities. However, copper is uch less expensive, has a higher celting point 1083 vs $950^{\circ} \mathrm{C}\left(1980\right.$ vs $\left.1760^{\circ} \mathrm{F}\right)$, and in the proper grade it can meet all the requirements without exception. External lead-in leagths will be aininized to increase: the heat sink capability of the vater-cooled cunnecting bus bars presently envisioned. This in turn will effectively linit the tecperature of the two coaxial copper lead-in conductors for each heater.

\subsubsection{Interwediate Materials}

The Internediate aterials wst have selting points above that of the heating element aterial and should also have a reasonably low voluse electrical resistivity. Holybdenu would be the cptime aterial fron these two viewpoints, with tungsten a close second cholce. However, velding (or other attachnent technique) problems exist with wolybdenus, as evidenced by previous usage (and attented uage) in the UTPR fuel pin simulators. Fabrication problem and the poor avallability of suitable tubular form (for the outer intermediate enterial) iurther contributed to the decision to not use efther of these materials.

Nickel meets the above two stated requitements and is eanily fabricated and welded or brazed. On the basis of experience in the LWFB heater designs, it is compatible with the $B$ at temperatures of interest. It is available in a autituie of sizes and shapes and in the desired grades, such as Nickel 200.

\subsubsection{Fuel Pin Simulator Sheath saterial}

The PPS sheath waterial was essentially dictated by GA progran direction as type 316 stainless steel with a aminal wall thickness of 
$0.76-(0.030 \mathrm{in.})$ in the finished FPS. The diameter of the initial or starting tubes will be selected to pmvide 202 reduction during suaging. Heat transfer echancenent and any other surface preparation will be performed by $C A$ on the completed FPS.

\subsubsection{Electrical Insulazion}

Oaly boron nitride has been considered for the electrical insulation of these FPSs. The low values of thermal conductivity of magnesium oxide and aluninu oxide (as well as the variation of their thernal conductivity with density) preclude their use in high-heat-flux heaters that anst operate at high temperatures under transient as well as steadystate coaditions. Beryllium oxide was not considered because of its toxicity, hardness, and high cost.

Previous research with BN pouder (and hot-pressed aterial) on the LMFBR and PWR fuel Pin simulators has develozed several candidate BN materials and has elfainated other pcssible BN mierials and types. The required material must be very pure and cannot undergo phase changes below the maximu required operating temperatures. This eliminated UCC rype HCT-48 (also known as type TS-945) and the only known Carborundum BN powder.

liewer BN pouders such as UCC tyl: HD-0092 and type IS-1206 have vielded satisfactory results when tested in sample LiFBR heater configurations for insulation resistance and compatibility with heating element material at cemperatures up to apprcximately $1427^{\circ} \mathrm{C}\left(2600^{\circ} \mathrm{F}\right)$. However, these aterials will not normally be avallable fros: UCC in the future, so altemate aterials were considered.

Boron attride of JCC type HCA, which is made similarly to UCC type HD-0092, will be available in quantity in the future. Evaluation of FPI 3 of the LMFBR design made with the HCM pouder has yielded satisfactory results on both nondestructive and operational test bastó. In laboratory tests, the porder has been cold-pressed intu preform having satisfac:ory strength.

This and other types of pouders will be evaliuted further early in FY 1976 by use of "conductivity cells," which w11l be received the 
last of FY 1975. The "conductivity cells" will be used to measure thernal conductivity of the compacted powder as a furstian of density and of the type or grade of BN pouder as well as to measure the electrical condurtivity as a function of tepperature to $1427^{\circ} \mathrm{C}\left(2600^{\circ} \mathrm{F}\right)$. This hightemperature testing will also provide ccrpatibility data. These "conductivity cells" are belng fabricated by two different anufacturers to compensate vendor-dependent characteristics.

The design of the CCFR fuel pin siculators was based in part on the use of cold-pressed preform. Research and development in this area were initiated earlier in the LrobR progran and will be continued. Laboratory results have been very pronising and are being discussed in detail with the potential comercial vendor. When suitable prefors are avallable, mafacturers using these preform uill fabricate additional "conductivity cells" to evaluate thelt use in heater configuration.

Upon cospletion of the analysis of the data obtained fron the "conductivity cell" and the ax preform, we can optinize the Bi density and select the type. Ef fects due to any anisotropic characteristics achieved can be properly evaluated as well as the relative uniforaity of any characteristic or property of the candidate anterials.

As previously noted, this development sill be a coordinated effort with the prograns for development of other types of fuel pin simulators at 0 pord.

\subsubsection{Fuel Pin Stmulator Specification}

A specification was writtea to detail the proceduses for material selection, fabrication, and nondestructive testing of the GCFR fuel pin simlators. It includes a series of quality sesurance proceduras detailing inspections performed or witnessed at the factory by our on-site inspector. This specificat ion was reviewed in a weet ing with Ga in April 1975, ar.d is being revised.

\subsubsection{Quality Asr.urance}

Applicable quality assurance covers design, mterials procurement, FPS fabrication, and rondeatructive teating of finished units. In 
addition to the FPS specification, the following standards apply in total or in part to patinent FPS meterials:

IIT F 3-6 I loodestructive Exosalnation, BDT M 3-2 T Sealess Ferritic and Austenitic Alloy Steel Tubes, ASTM B is Seanless Copper Tube, ASTM B 152 Copper Sheet, Strip, Plate, and Rolled Bar. ASTM B 160 Xickel Rod and Bar. ASTM B 161 Mickel Seanless Pipe and Tube, ASTH B 344 Specification for Drwa or Bolled Nickel-Chroniun and Nickel-Chromiu-Iron Alloys for Electrical beacing Requi rements,

AMSI C 96.1 Temperature Hensurenent Termocouples, QQ-1I-209A Hickel Plating.

The aterials are being ordered to these specifications and are inspected in accordence with then to sesure conforaty of the FPS to the design configuration, FPS-to-FPS uaffornty, and rellabllity of the internal therrocouples.

Detailed specifications are not yet avallable for the BN pouder so each inconing lot is analyzed to deternine inpurity levels of carbon, oxygen, and many other elemeats that could be detrinental to its properties. In addition archive saples are kept $t_{0}$ ald in later evaluacion if problem occur.

Fabrication will be closely conitored by an on-site inspector, who will witness or perfor Inspections in accordance with writien Qh Inspection procedures after every major fabrication step. Problems found with Bx density, mterial dinensions, insulation resistance, etc. will be corrected before the next. processing step.

After the finfshed FPS has been recelved, radiographs, inf rared scans, and thernocouple junction location searches will be ande before acceptance. Radiographs show up such cefects as coll eccentricity, pitch perturbations, voids in core insulation, and some defects in aterial interfaces. Infrared scans are used to deteraine variations in an density, theraal conductivity, and cladding thickness an well as coll pitch pertubations. The therwocoupie search test consists of using a heat 
so:irce and measuring therwocouple response to the heat. The axd wo response locates the thernocouple junction. Junctions can be located to within $3=(1 / 8$ in.) by this method.

Work is in progress to autonate the infrared (IR) facility and to provide an automated $x$-ray radiography systen. These nodifications, when conpleted, significantly increase throughput capability as well as accuracey.

The radiography facility generates a small-diameter $x$-ray bear which is passed through an FFS woving at a fixed rate. The bean is detected after passing through the FPS, and an analog voltage is produced. The output car be used to very accurately deternine ribbon spacing, width, tuens per unit length, and eccentricity.

The automation of both the IR and radiography will consist first of obtaining equipment to produce a digital output of the signal and second of providing sof tware to convert the ras data to suitable output information. These should both be completed in time to evaluate the first GCFR FPS.

\subsubsection{Procurement Activities}

Procurement and testing of final production fuel pin simulators are the last steps in a series of prior activities, which inclicie: (1) procurement of long-lead-tine and/or critical mterials, (2) discussion of design with manufacturers, (3) procurement of prototypes from participating mufacturers, and (4) testing and evaluation of prototypes in one or wre rounds to select a qualified vendor or vendors for production heaters.

Procurement of the Nichrome $V$ heating elewent, the stainless steel sheath, and the BN Insulation is complete. Grade HCM BN powder has been obtained for use in the prototypes. Preform will be obtained for production heaters if they are manufacturable and their properties are beiter than those of the pouder, as expected. The lead-in and return elements were considered noncritical and will be handled by the anufacturers.

Several discussions have been held with manufacturers to work out detalis of design and fabrication. Purchase requisitions for prototypic heaters were sent out to $81 x$ manufacturers, and purchase orders have 
been given to five of them: RAMA Corporation of San Jacinto, California; SExco of North Hollywood, Califorala, Watlow Electric Manufacturing Coupany of St. Louis, Missouri; General Electric Comany of Seatcle, Yashington; and Advanced Heat Concepts, Inc., of Addison, Illinois. Materials for the heater sheath, heating elements, and $B N$ have been sent to these anufacturers, and favrication is in progress. The first units of these prototypes are due in the first quarter of FY 1976, and evaluation will begin upon receipt.

\subsubsection{Thermocouple Noise Evaluation}

Mockup FPSs have been designed and procured for characterizing electromagnetic interference ncise (eni) induced on different types of thermocouples inside the heater by $d j$ fferent candidate power and control systems that will be evaluated for the CFIL test bundle application.

Three differ'st types of therwocnuple installations are provided inside each FPS. One is an intrinsic thermocouple consisting of two individually sheathed $0.38-\mathrm{OD}(0.015-1 \mathrm{n}$.) type $\mathrm{K}$ therwoelewents, each of which is spot-welded to the inside surface of the heater sheath. The other two thermocouples are sheathed 0.51- OD (0.020-in.) type K thermocouples, one with a grounded junction and the other with an insulated junction.

The FPS configuration is similar to that for the prototypic GCFR FPS, except that all current-carrying components (Including the colled heater element) are fabricated from copper, and magnesium oxide insulation is used in lieu of $B N$. The unit will be operated at rated current conditions to mock up the magnetic fields that would be present in the bundle heater. Electrical fitelds can be imposed by applying an appropriata potential between the heater sheatt. and one of the copper lead-in conductors.

Fabrication details of the mockup FPS were woried out with the RAMA Corporation, and a prototypic FPS was evaluated. Minor chazges were made, and RAMA has fabricated ten such units. Problems arose in connection with the attachment of thermocouples to the inner sheath, but RAMA resolved the problems. 
The wockup FPSs will be assembled in a seven-rod bundle. These will be operated in various test wodes with differing numbers of FPSs and different power and control systems to analyze thermocouple noise. Appropriate filter circuits to elininate the noise or reduce it satisfactorily will be designed and tested as required. Based upon these rasults, the best thernocouple design will be employed in the second round of prototypes and in the production FPS.

\subsubsection{Test Section for FueI Pin Simulator Test Loop}

To evaluate the operational characteristics of the GCFR prototypic FPS without incurring large financial costs, the vertical test section in the existing LMFBR FPS Test Facility was modified to the increased diameter and length of the GCFR FPS compared with the FFM FPS. The design was completed in February 1975, the required materials were obtained, and the fabrication activities were completed in June 1975. The vertical test section will be installed in the loop in time for prototype tesis, which are scheduled to begin in the second quarter of FY 1976.

\subsection{ELECTRICAL POWER AND CONTROL SYSTEM FOR CFTL TEST BUNDLE -}

T. L. Hudson and J. R. Stansberry

The operating conditions of the test bundle require a source of electrical porer that can be accurately controlled and quickly changed over a wide range of power levels to provide the power transjents required of the CFTL. Of the various techniques studied and still being considered are those employing silicon-controlled rectifiers (SCRs). Because electromagnetic interference (emi) noise is seen on the FFM heater cladding therwocouples with the Arstalled SCR systems, it was decided to make the CrTL power supply and control system the subject of development effort. The status of both the ac and dc power supply and control system being considered and tested for evaluation is reported.

\subsubsection{Test Bundle and Control Criteria}

The criterla for the fower supply and control for the fuel, control rod, and blanket test bundles for both flat (constant power across bundle) 
and skewed (decreasing porer level across bundle) power distributlons and for both steady-state and transient operation have been developed and are shown in Tables 3.6 and 3.7. Exapple: A test bundle consiating of 91 heaters will be controlled in 11 zones (which corresponds to the nuber of rows of heaters fron flat to flat across the hexigonal bundle configuration), while a buadle of 19 rods will be controlled nomianally In five zones. The maximusundle poser denand, (aintety-one 45-kH henters), wili be $4100 \mathrm{kH}$, with each zone rated at $500 \mathrm{kH}$ maxim.

Table 3.6. Criteria for the Power Supply of CFTL Test Bundles

\begin{tabular}{|c|c|c|c|c|c|}
\hline \multirow{2}{*}{ Budle } & \multicolumn{2}{|c|}{ Exal Power, kH } & \multirow{2}{*}{$\begin{array}{l}\text { Wher of } \\
\text { Dow of } \\
\text { Werers }\end{array}$} & \multicolumn{2}{|c|}{ Duber of Bealers } \\
\hline & per Benter & Totel & & Totel & per nor \\
\hline Fuel & 45 & 4100 & 11 & 91 & $6,7,8,9,10,11$ \\
\hline Control and & 45 & 4050 & 13 & 90 & $\begin{array}{l}7,8,9,6,6,6,6,6, \\
6,6,9,8,7\end{array}$ \\
\hline Blanket & 11 & 1400 & 13 & 127 & $\begin{array}{l}7,8,9,10,11,12,13, \\
12,11,10,9,8,7\end{array}$ \\
\hline
\end{tabular}

Table 3.7. Criteria for the Control of CFTL Test Bundles

\begin{tabular}{|c|c|}
\hline Note of Oparation & Criterle \\
\hline \multicolumn{2}{|c|}{ steod-stece osereklon } \\
\hline net power diseributlon & 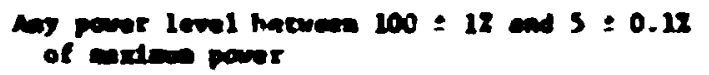 \\
\hline 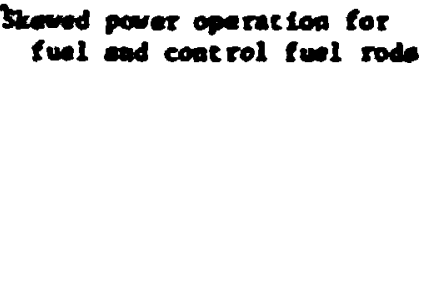 & 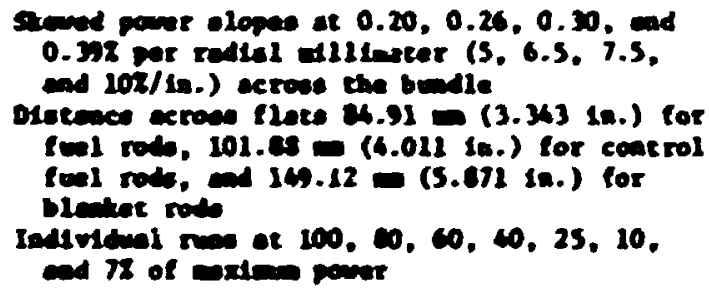 \\
\hline Showd nowe opretion for & 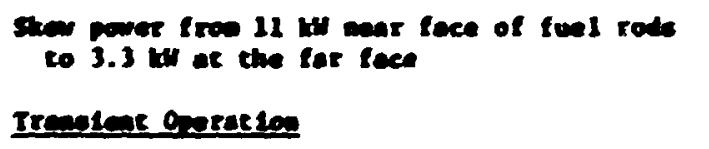 \\
\hline nat pover deersbuedon & 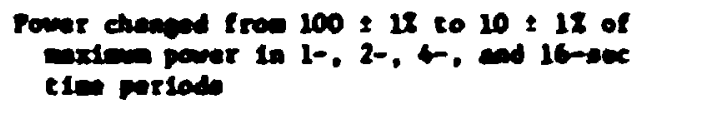 \\
\hline Shewed poner & 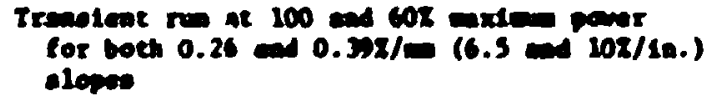 \\
\hline
\end{tabular}




\subsubsection{Pourer Systen}

A new substation consisting of two 2500-kVA, 3-phase, 13.8-kV-to480-V, self-cooled pad-wunted transformers will be located outside the bullding and will be connected to the extsting 40-iva transformer located within 53 a (175 ft) of the CrTL at the coutheast corner of Building 9201-3. The two trasformers wil be equipped with eight raise and eight lower load cheaging tape to provide $\$ 7.57$ total change in the secondary voltage of the substation. A one-line diagran of the power systen is shown In F18. 3.18.

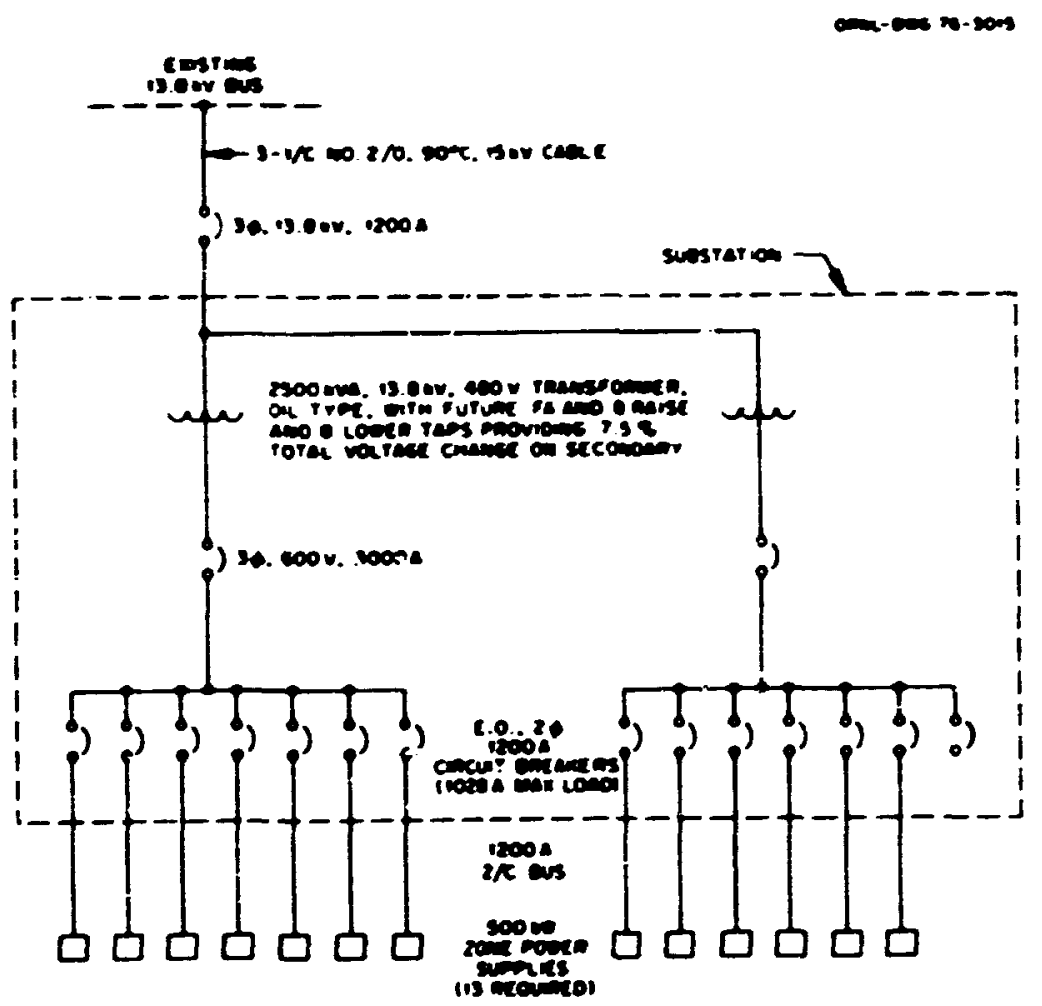

118. 3.18. One-Line Diagran of Power Systen for GCFR Core Flon Test loop (CFIL).

\subsubsection{Power Control Criterie}

During steady-state operation the teat bundle power control (the control) aus provide for adjustnent in power level from 5 to 1002 of design power. Also, for skewed distributions power levels mat be adfusted from 1.67 to 3.347 between adjecent FPS rowe. During 
transfent operation, the control must change power from 100 to 102 of design level with 1-, 2-, 4-, and 16-second intervals for both flat and skewed distributions fron predeterained set points.

\subsubsection{Development and Testing}

Claddiag tesperature is important to measure during a simulated GCFR reactor trip fron 100 to 102 of design power in as short a time as 1 sec. Also, electromagnetic interference (emi) noise is seen on heater cladding thermocouple signals fron test bundles in the LAFBR Fuel Failure Mockup (FTI) with the installed ac power supply, which uses analog-cont rolled silficon-controlled rectifiers (SCRs). Therefore, we decided to make the CFTL power surply and control systen the subject of engineering studies and development effort. The following four systens were studied and discarded.

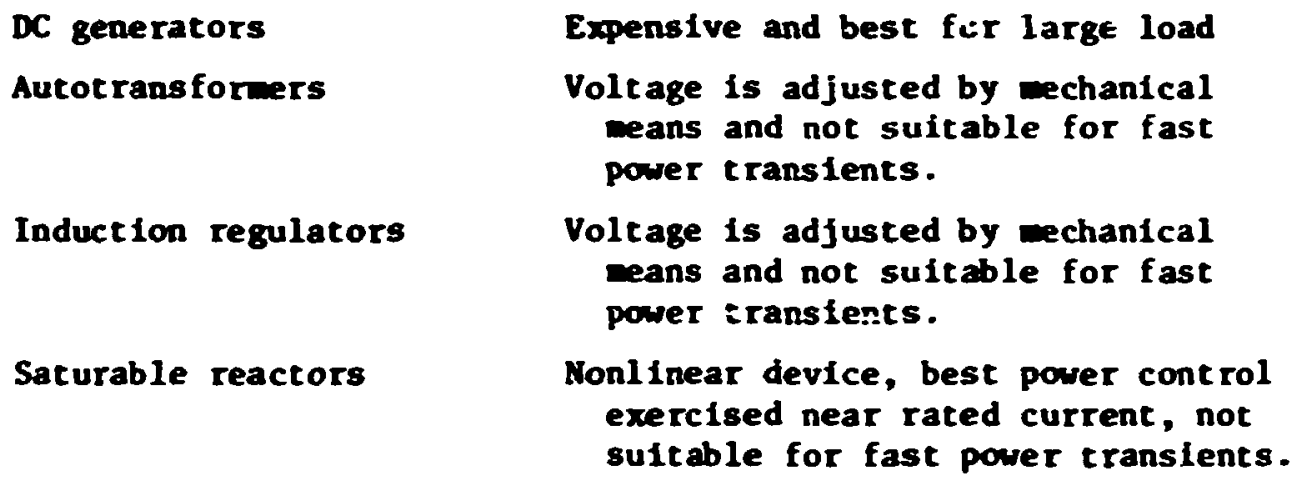

Both ac and dc power supply and enatrol systems using silicon-rontrolled rectifiers (SCRs) are being considered, and will be tested and evalunted. The $d=$ systen (using phase-angle-fired SCRs) will have the capability to supply the bundle heaters with continuously varianle dc voltage. The ac systems (using zero-voltage firing) in general will control heater power with a combination of switching various values of $t$ ransformer secondary voltage into the test bundle heacer circuits and proportioning the time the heaters are connected to the power source.

\subsubsection{AC Yower and Control Systems}

A linear mitipower level (LMPL) and a linear witivoltage level (LMVL) scheme for controlling the ac power to the FPS bundle are to be tested and evaluated. Both analog and digital techniques for controling the SCRs have been studied. 
3.6.4.1.1 Analog Technique. The time proportioning control for the FFH, which uses analog techniques, was studied first. Sowe disadvantages to the CFTL of this control are:

1. The anime power step is $5 z$.

2. SCRs provide 1/2-cycle power. The difference in the nubber of positive and negative $1 / 2$ cycles of ac current produces a dc component. If the dc component exceeds about 27 of the ac current, the transformer core will saturate and the transforer will overheat.

3. The pover level drifts randony from 1 to 22 .

To overcone the disadvantages of the FFI control, an inproved time proportioning control, again using analog techniques, was designed, and a breadboard wodel of it was built. Some features of this control are:

1. The initum power step is 1.672 .

2. SCRs are fired for full cycles of power.

3. The control systen is timed to the $60-\mathrm{Hz}$ power frequency, wich elininates the randon drift of the power levels.

The wave forms of the power provided to the test bundle with this control are presented in Fig. 3.19. The results of calculations made to show the effect of this tine proportioning control on the temperature of the outside surface of the heater cladding are shown in Fig. 3.20. The axdmen variation in surface texperature occurs at 507 power and is further increased as the control period is increased in length. This analog technique has been abandoned in favor of the digital technique.

\subsection{Digftal Technique. The analog techniques are hampered} by several factors. First, the amplifiers are subject to drift and of fset and are sensitive to temperature changes and component aging. Second, they typically require a number of adjustments over a period of time to achieve a desired power level. Power is usually determined by counting the number of power pulses delivered to the test bundle over a relatively long period of tive $(10 \mathrm{sec})$; then appropriate adjustments are made to the control and the process is reiterated until the required power is obtained. 


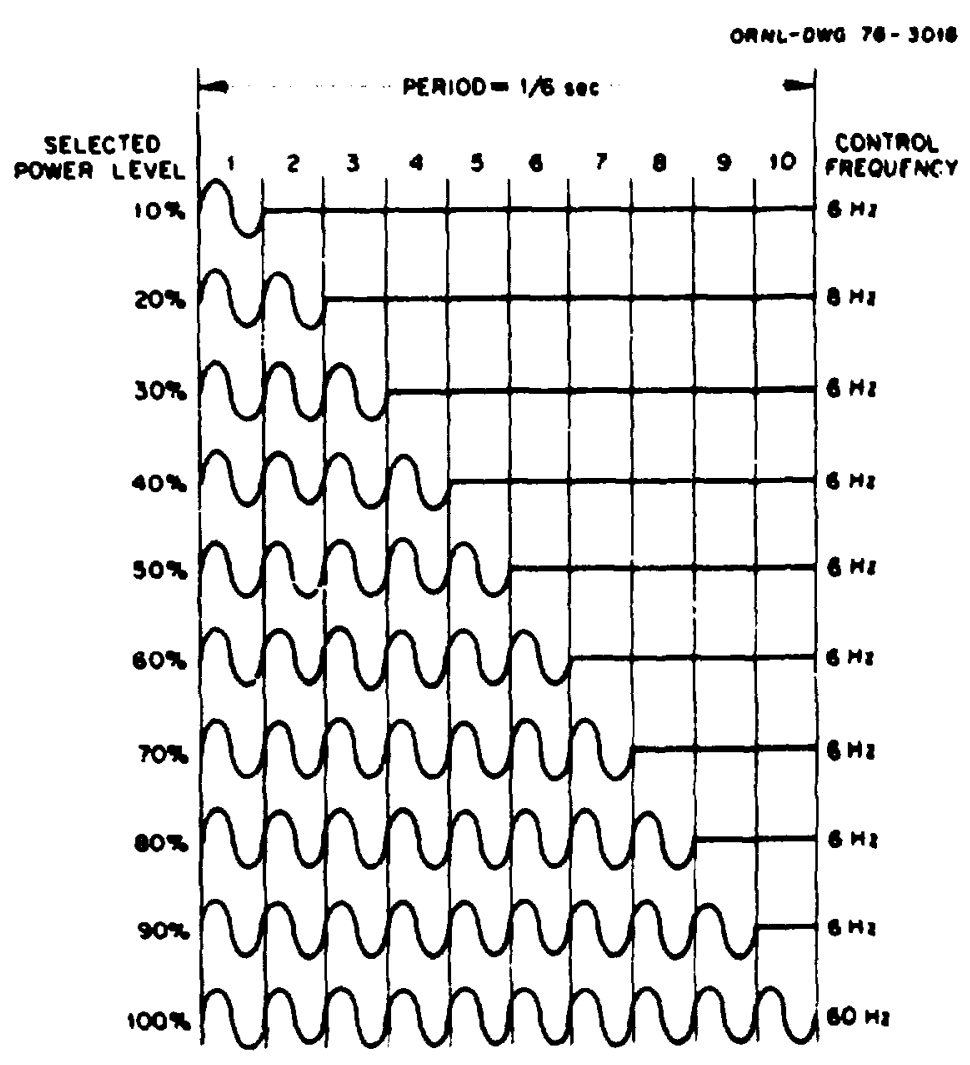

F18. 3.19. Wave Forms Produced at Heater by AC Power Supply Using Analog Control with 10\% Control Stages.

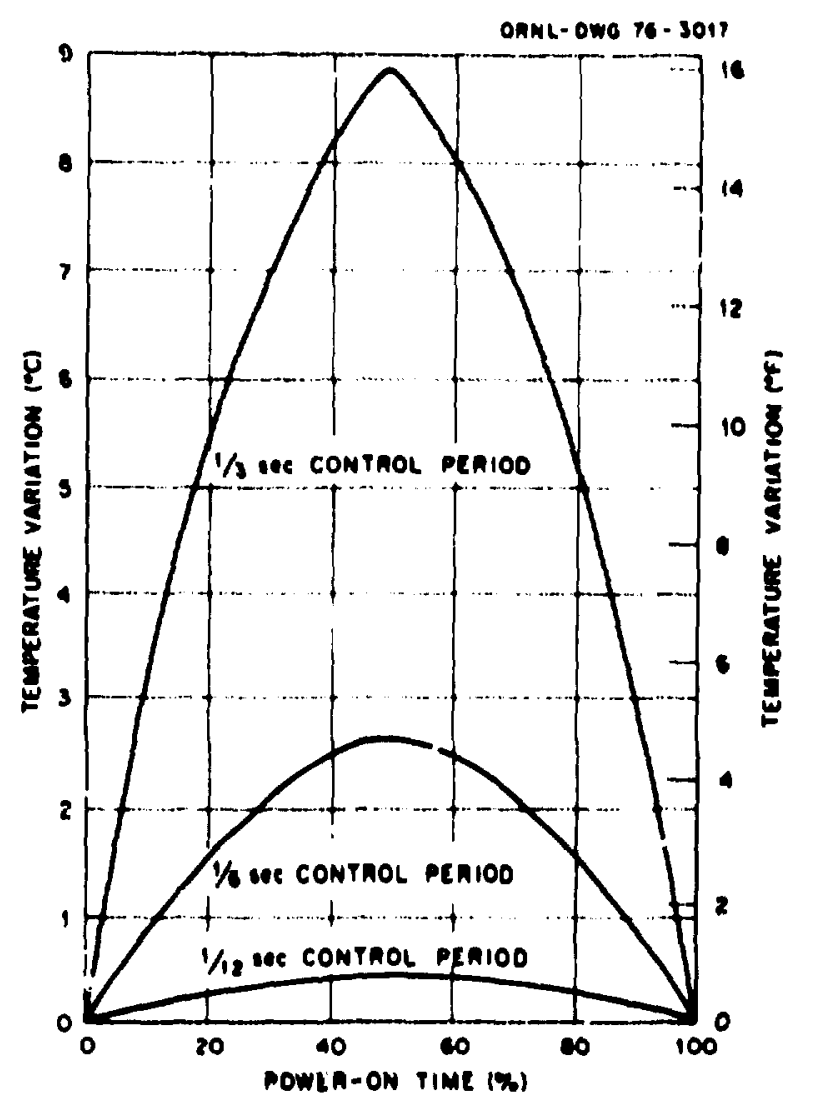

F18. 3.20. Variation in Heater Sheath Temperature with Power-On Time at 100\% CPTL Heater Power with 60- Hz AC Supply for Various Control Parlods with the Analog Control Syetem Ueed. 
To overcone these picblems a digital control was designed and a prototype vas bullt. The wave form of the porer provided to the test bundle with this cuntrol for 102 power steps are presented in Fig. 3.21. Sore features of this control are:

1. Power control in 12 increments can be achieved.

2. SCRs are fired for full cycles of pouer.

3. Power settings are reproducible because there is a one-to-one correspondence between the thubwheel switch setting and the output power.

4. The thubuheel switches, which visually indicate the porer level, provide a very accurate measurenent of steady-state power.

5. Interfacing with digital computers and other digital equipwent is quite simple. A digital binary coded dectmal (BCD) word may be tied directly into the controller to perait control from an appropriate programer.

6. The control frequency assoctated with a 1/6-sec period varies from $6 \mathrm{~Hz}$ at $90 \%$ to $3 \mathrm{C}, \mathrm{Hz}$ at $50 \mathrm{z}$ power, as compared with a constant $6 \mathrm{~Hz}$ frequency for the anal.og control with $1 / 6$-sec period.

The variation of the heater surfacr. tenperature with power-on-tive is plotted in Fig. 3.22. When this plot is compared with the 1/6-sec period plot in Fig. 3.20, it shows that for the $50 z$ power the sheath temperature variation has been decreased from 2.7 to $0.1^{\circ} \mathrm{C}\left(4.8\right.$ to $\left.0.2^{\circ} \mathrm{F}\right)$ and at powers of $10 z$ and below and $90 z$ and above the variations are essentially the same. However, to achieve 17 increments of power control with the digital technique requires 100 cycles of $60 \mathrm{~Hz}$ power. This results in a predominant $0.6-\mathrm{Hz}$ control frequency above $90 z$ and below $10 z$ power. Another method to achleve 12 incremental power control is the application of an induction regulator into the primary of the supply transformer to each of the individual control zones. The regulator or similar equipsent will be a necessary adjunct in any ac fowe: control schese to obtain the settings for the Individisal zone power levels in preparetion for test bundle transients with skewed power distributions.

3.6.4.1.3 Iinear Multipower Level. In the linear m:1tipower level scheme the zone transforwer secondary consists of a single winding with 


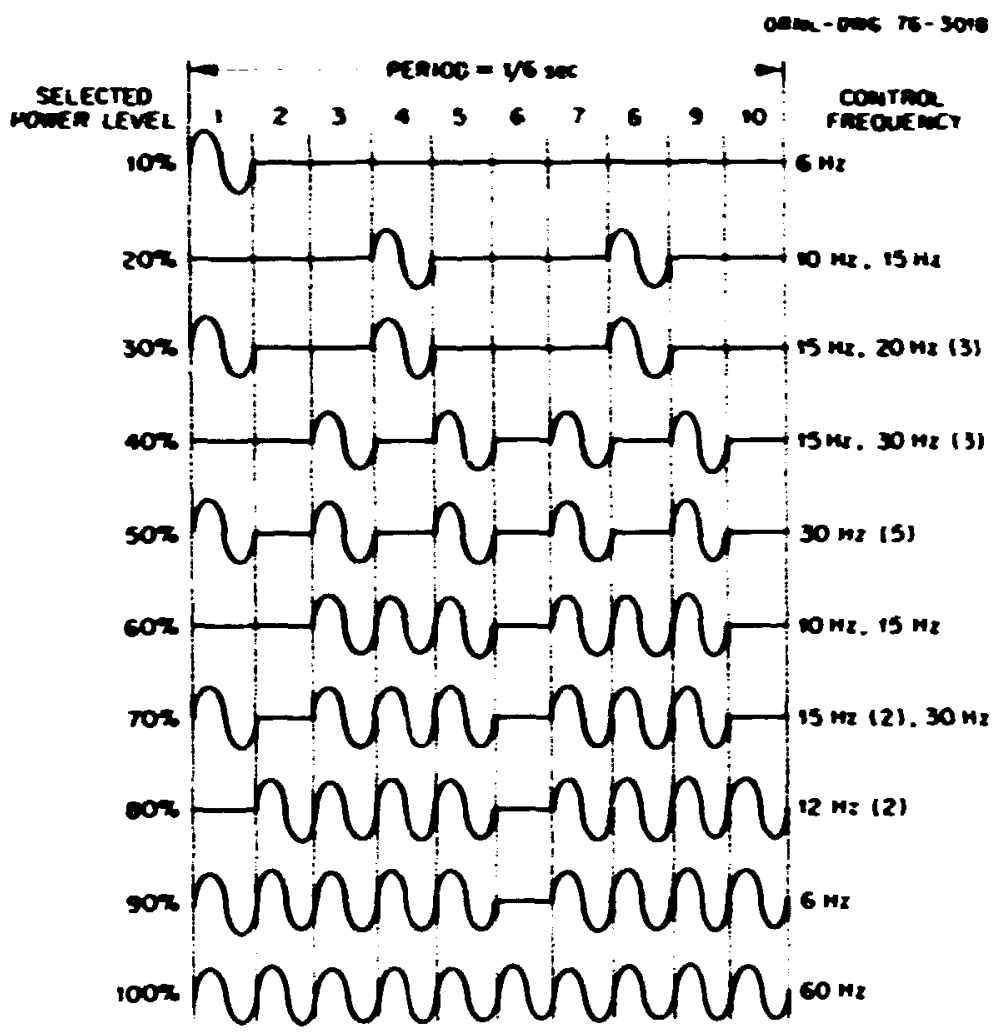

Fig. 3.21. Wave Forms Produced at Heater by AC Power Supply Using Digital Control with 107 Control Stages.

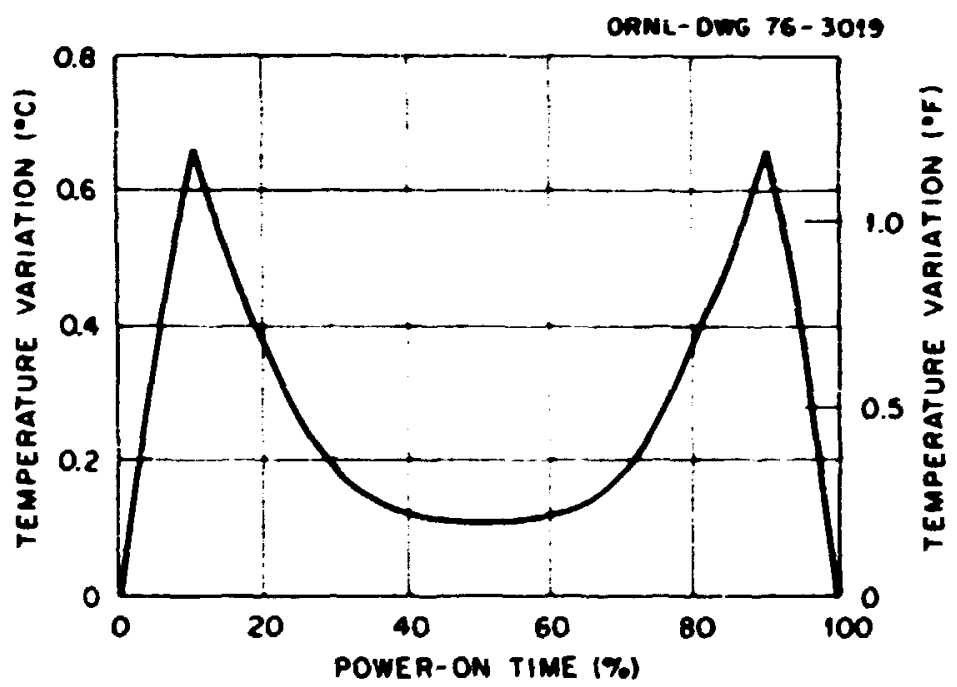

Fig. 3.22. Variation in Heater Sheath Temperature with Power-On Time at $100 \%$ CFTL Heater Power with 60-Hz AC Supply Using the Digital Control System. 
taps to provide linear power steps between the taps. Both a singleand a five-power-level systea will be cested, and the SCRs will be controlied during steady-state operation by the digital control systen and during transient operation by a function generator whose functions replace the funciions of the BCD surtches. A single power level with the digital control system meets the steady-state requirements in Table 3.7. The ain advantage of the five-power-level systen is that the lowest control frequency is $30 \mathrm{~Hz}$ during a power transient, as show in Table 3.8. If the nuber of power levels is increased to ten, the lowest control frequency is still $30 \mathrm{~Hz}$ for the 1-, 2-, and 4-sec transients, but the nuber of power steps has been increased from 9 to 18. For steady-state operation, the five-power level system provides 0 to 1002 power control in $U .27$ power steps.

Tab Le 3.8. Sumary of Transient Capabilities of AC Pci:-: Supplies

\begin{tabular}{|c|c|c|c|c|c|c|c|c|c|c|c|}
\hline \multirow{3}{*}{$\begin{array}{l}\text { Poner or } \\
\text { Volcape } \\
\text { Levels }\end{array}$} & \multirow{3}{*}{$\begin{array}{c}\text { Paire } \\
\text { of } \\
\text { SClo }\end{array}$} & \multicolumn{10}{|c|}{$\begin{array}{l}\text { Muderer of } \\
\text { for Eech }\end{array}$} \\
\hline & & \multicolumn{2}{|c|}{$1 \mathrm{sec}$} & \multicolumn{2}{|c|}{2 sece } & \multicolumn{2}{|c|}{$\& \sec$} & \multicolumn{2}{|c|}{16 sec } & \multicolumn{2}{|c|}{$10 \mathrm{de}$} \\
\hline & & $6 \mathrm{te}$ & $30 \mathrm{Ax}$ & $6 \mathrm{Bz}$ & $30 \mathrm{Bz}$ & 6 : 12 & $30 \mathrm{nz}$ & $6 \mathrm{Bz}$ & $30 \mathrm{nz}$ & $6 \mathrm{~Hz}$ & $30 \mathrm{Bz}$ \\
\hline \multicolumn{12}{|c|}{ Llacar Muletponer Level } \\
\hline 1 & 1 & $r^{*}$ & 2 & $9^{\circ}$ & 2 & $9^{2}$ & 2 & $s^{a}$ & 2 & $90^{\circ}$ & 2 \\
\hline 5 & 5 & 7 & 9 & 9 & 9 & 9 & 9 & 9 & 9 & 360 & 9 \\
\hline 10 & 10 & 7 & 18 & 13 & 18 & 18 & 18 & 18 & 18 & 360 & 18 \\
\hline 15 & is & 7 & 27 & 13 & 27 & 27 & 27 & 27 & 27 & 360 & 27 \\
\hline \multicolumn{12}{|c|}{ Llecer Huleivol care Level } \\
\hline 4 & 16 & \multicolumn{2}{|c|}{27} & \multicolumn{2}{|c|}{27} & \multicolumn{2}{|c|}{27} & \multicolumn{2}{|c|}{27} & \multicolumn{2}{|c|}{27} \\
\hline
\end{tabular}

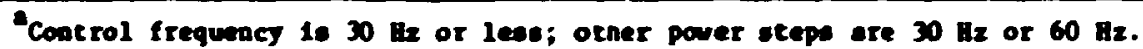

bcontrol frequeney to $60 \mathrm{~Hz}$. Addielonal power stepe cen be obtalned by tice-proportional arching betwen the coro clowest witate levie. 


\subsection{Linear Multivoltage Level. In the Iinear multivoltage} level schene to be cested, the zone transformer secondary consists of four separate windings, wth the voltage selected to provide 40 linear voltage steps as the four uindings are added, subtracted, or resoved in a programble fashion with a acroprocessor. The largest pover step is $4.94 \pi$, which occurs just belou full power, and she smallest power step 180.0637 , which occurs just above zero-power transient. The power stepis during a $100 \mathrm{z}$-to-10z transient vary from $4.94 \mathrm{z}$ for the first step to 1.562 for the 27 th step. If required, addicional power steps can be obtained by time-proportional sutithing betweer. the two closest voltage levels.

\subsection{Transient Capabllities. A sumary of the transient} capabilities of the linear witipower level and linear mitivoltage level supplfes is shown in Table 3.8. Heater sheath tenperature has been calculated as a function oi step changes in heater power for the CFTL heaters for fou: and nine equal power steps from 1002 to $10 z$ power. The sheath telperature is plotted against time for the 1-sec transient and nine equa: power steps in Fig. 3.23. The p! ot is represeatative of the 1-sec transient for a five-power-level linear multipower syster.

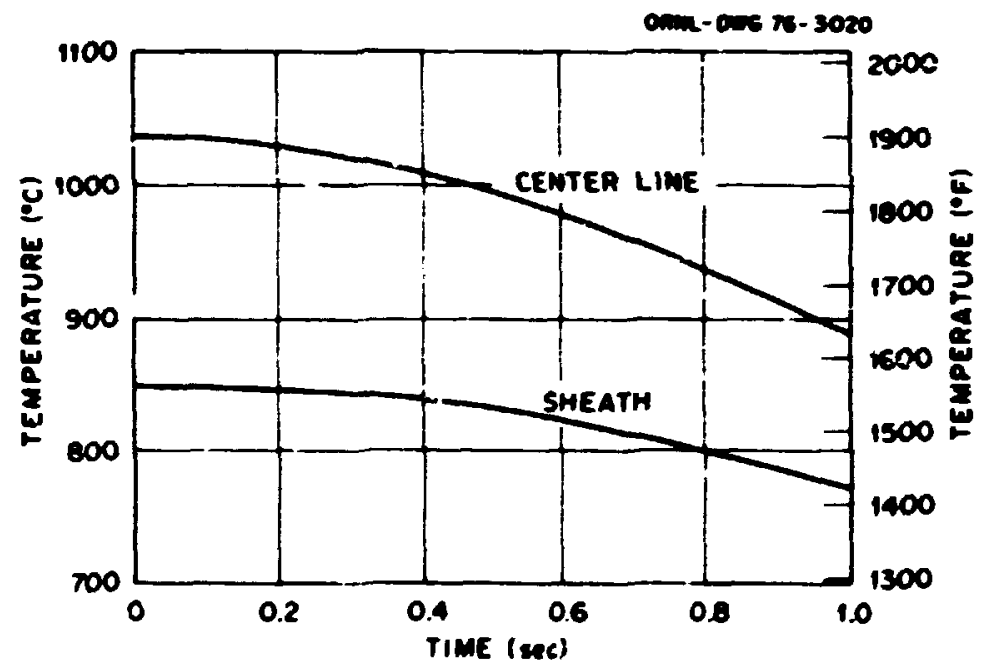

F1g. 3.23. Heater Sheath Temperature vo Time for a Power Transient from 100\% Rated Power to $10 \%$ Power in Nine Equal Steps over an Interval of $1 \mathrm{sec}$. 


\subsubsection{DC Power and Control Systee}

The difficulties of atching the characteristics of the large dc notor-gewerator sets alreedy installed at own to the pouser regutrewents for the CFIL test budles encouraged us to look into the rectification of ac pourer with SCR equipent. He vere also encouraged by news of plans to we rectified de power in the Seat-Seale facility at Idaho Nuclear Engineering Lbboratory and in the controlled Thermonclest Research progres at tibe Laboratory. In this schene, the SCRs are criggered to conduct at vorlows soltage phase angles and thus to produce an output woltage that is an average of the corduction portion of the wave form. The voltage phase angle for firing the schs ay be varied to give a very accurate and continuous control of tai output de voltage. However, phase-angle firing can protuce steep wavefronts, which generate a large anount of nolse in both the power supply and output. By exploying polyphase system such as 6 or 12 phases, both ripple and noise are reduced in size and latensity and elevated to frequencies that pernit conventent and reliable filtering of the output power.

The dc power and control should neet all the contro:led power requirewers for CFTL test bundles as shom in Tables 3.6 and 3.7. To evaluate the anount of noise in the input of the de porer supply and the effects of the electromgnetic interference nolse (emd) on the FPS thernocouple sigal, a 60-kH dc power supply (six phase) is being purchased (delivery scheduled July 15) with the capability for testing the lor-power heaters in the seven-rod FPS test bunale and also testing a single protatypic FPS at full power and ceaperature in the FPS Test Fac1lity.

\subsubsection{Transfer Function Test}

The dc poser supply esploying phase-fired SCRs being considered produces in the output considerable anounts of nolse in the form of harmics of $60 \mathrm{~Hz}$. The effect that this ncise has on the heater internal thernocouple signal is difficult to deterwine inlees the degree of electromgnetic coupling between the heater ele ment and the thermocouple leads is known. Tests are to be conducted to deternine the degree of 
cospling is a function of frequency. With the data that are expected :0 or atratned fron the test it uill be possible to compte the noise appoering ix the thernocouple lines for a given configuration of power supply and filter.

The enintenance on an arailable 30-kH, 400-Hz generator was conpletei, and the generator has bees reinstalled. It will be used to detendive the heacer-to-thermorouple transfer function in the 60 to $400 \mathrm{~Hz}$ range. A variable-frequency oscillator supfly has been checked for posstble use in mesuring the transfer function. ii e outint of this supply is ?inted to about $50 \mathrm{~V}$ and $4 \mathrm{~A}$. By using a to 1 - step-down transformer, 10 A at $1080 \mathrm{~Hz}$ has been obtained when the sufply was connected to a 1- $\Omega$ load, which is approxir-tely the electrical rusistance of a CITL icst bundle heater. By the proper selection or desigs: of a step-down trans äoner, at way be possible to extend the iseful frequency range of the transfer function test.

\subsubsection{Seven-Rod Heater Test}

The seven-rod FPS test bundle is being built to test and evaluate the ac and dc power supplies. The assembly for holding the simulators which has bcer. fabricatri, has the sawe FPS spacing as the CFTL bundle. The assembly will be installed in a water :ank to provide adequate cooling. Three different types of thermocouple installations w111 be provited inside each FPS. One is an intricsic thermocouple consisting of two individually sheathed $0.38-0 D\left(0.015-1 r_{i}\right)$ type $K$ thermolements, sach of which is spotwelded to the inside surface of the heater sheath. The other two thermocouples will be sheathed $0.51-$ mon $00(0.020-i n$.$) type$ $K$ thermocouples, one with a grounded junction and the other with an insulated junction.

The FPS configuration will be similar to that for the prototypic FPS, except that all current-carrying components (including the coiled heating element) will be fabricated from copper, and magnesfum oxide insulation will be used in lieu of joron nitride (BN). These low-power heaters will produce about $750 \mathrm{~W}$ when operating at $160 \mathrm{~A}$ (rated current of CFTL heaters) and $4.6 \mathrm{~V}$. 
A peth panel cabinet has been designed and built to allow the sevia heaters to be cornected in various series and parallel combinatiors guch that the worse noise condition can be obtained. if possible, we will deteraine hou ach of the thernocouple noise is a result of the current on the center heater, and how much is caused by the surrounding heaters.

The design of the linear multipower-level and linear mltivoltagelevel ac power systems has been completed, and much of the equipment has been fabricated. The initial test with a single-power-level system is scheduled to start by July 1, 1975.

The following is a sumary of the tests planned for the seven-rod FPS bundle:

1. deternine transfer function of heater and therwocouples;

2. characierize the steady-state and transient peiformance of the ac and dc power supplies;

3. dezernine input noise to therwocouples from the heaters for both steady-state and transient conditions;

4. estabilsh filtering techniques and capabilities.

\subsubsection{HIgh Temperature and Power Test}

Tests sinflar to those planned for the single-FPS test in the seven-rod FPS bundle will be conducted on a single prototypic CFTL simulator in the FPS Test Facility. The seven-rod FPS test bundle ac poiter suppiles will be modifled by replacing the zone transformer and the primary Powerstat for the higher current and voltage rating. No modification of the $60-\mathrm{kH}$ dc power supply is required. Because of the low power and temerature rating of the heaters in the seven-rod bundle, the full-power testing of the candidate power supply and controls will be conducted in the FPS Test Facility.

\subsubsection{Heater Protection}

Each test bundle FPS will be protected with a current-limiting fuse. We are studying additional protection for each row of FPSs with a ground fault interrupter (CFI) or stmilar device to detect small leakage 
currents by mitoring the difference in the value of the currents in the two power supply leads for each row of FPSs. A prelininary design of an ac and a dc leakage current detector has bee- prepared, and a breadboard assembly has been built and is being evaluated.

\subsection{INSTRUEATATICN AND COATROLS - H. J. Hetz}

The early part of fiscal year 1975 arked the beginning of the involvement of the Instrumentation and Controls Division in the GCFR Core Fiow Test Loop (CFTL). As sorn as the conceptual loop design was atallable, masurement and control flow diagram were piepared to make cost estimates of measurements and controls for the loop. Later on, the CFTL Prograa Plan revealed requirements for mensurenents of test bundle paraneters, such as strain, wotion, and vibration, that would require research and development. Also the quantity of test bundle measurements was large. In subsequejt discussions between $G$ and ORM, the requiresents for measurements that needed development were elindnated. Also, the quanify of test bundle measurements was rediced to decrease the size of the high-speed data acquisition syster (HSDAS).

Study of the conditions to which the test bundles would be subjected, the design of the electric heaters that will simlate the GCFR fuel pins, and the electriral poser supply and control to the test bundle rods Indicated a high probability tl it electrical noise picked up by theraccouples instalied inside individual FPSs wotid ake it difficult ir impossible to obtain accurate data, particularly during the fast tiansients. Investigations reveaied a sertous nolse problea with ac prwer, wish probably will require filtering. The need for fast response of the sheath temerature thermocouples makes filtering somewh difficult when the frequency in less than 30 to $60 \mathrm{~Hz}$. This difficulty directed our attention to the test bundle power supply and control and the linear mitivoltage level scheme (Lail) described in Sect. 3.6.4.

The need to control five variables during rte fasi transients led to the development of a transient controller.

The prelialnary spectfication of an HSDAS was propo:ed. 
Because of concern about the accuracy and durability of the salldianeter therwocouple thrt will be installed in the FPS to measure sheath tezperatures, tests were ade to deteralne the viability of the design.

A gas chrowtograph for analyzing the CFIL hellun was investigated. The neon analysis, which would be very troublesone, was deleted from the requirements by mutual agreeneni with GA. Because of the different gases and the water vapor to be measured and the range of masurement, the chromatograph w11l be a rather complex continuous process instrunent having two coluns and two samplers.

\subsubsection{Coolant Heliue Flow Keasurement - H. J. Hetz}

The measurement of coolant hellum flow rates $[2.81-0.045 \mathrm{~kg} / \mathrm{sec}$ (6.3-0.1 lb/sec)] mast accomodate a flow satio of 63 . Th1s results in a required maximer-to-minimu differential pressure ratio of 3969 for velocity head floweters. Velocity head meters have a maximin flow ratio of approximately ten. Therefore, several different sized velo ity head weters are required to cover the CFIL flow ratio. Initially, venturi tubes were selected to measure steady-state test bundle and attemperator flow rates and total flow rate from the circulators. However, the response of venturi tub 28 , together with the associated piplag and differential-pressure transitters, is too slow to measure transient clows accurately. This would not allow test conditions to be verifled wth sufficlent accuracy to weet the requirements of the Program Plan. We found that target floweters, which also have a flow ratio of approximately ten, would have fast enough response to reasure the transient flows.

The use of venturi tubes and target floweters st each of the three flow weasuring stations would require four venturi tubes and two or three carget flowetere for each station. The cost troublesome part of the use of these velocity head floweters is the need to change weter size each tive the test bundle size is changed.

Additional possible methods of flow measuremenc were investigated. Uitrasonic flometers promise accuracy at a flow rar:10 of 75 , along with 
high-speed response and the capability to sustafn CFTL operating conditions. A prototype of the ultrasonic floweter is being purchased. We plan to test and evaluate this flometer either in air in collaboration with the Colorado Engineering and Experiment Station near Nunn, colorado, or in hellu at the U.S. Bureau of Mines Hellun Facility, Anarillo, Texas.

\subsection{2 dellue Flow Contro! Valves - H. J. Hetz}

Fast-acting valves will be needed to perform the necessary coolant heliu flow transients for test bundle and circulator bypass flows. other siaflar controls will be required for the cooling air flow to the two hellu-to-air heat exchangers.

The valve coefficients and the ratio of maximu-to-niniming valve coefficients (rangeability) for each test bundle were calculated. The largest pressure 1088 used in the calculations for fully open valves was $62 \mathrm{kPa}$ ( $9 \mathrm{psi}$ ). At $102 \mathrm{flow}$ the pressure drop used in the calculations was the circulator head minus the pressure loss in the test bundle and in the loop. The resnlts of the calculations are given in Iable 3.9.

Table 3.9. Test Bundle Valve Requirements

\begin{tabular}{|c|c|c|c|c|c|c|c|}
\hline \multirow{3}{*}{$\begin{array}{l}\text { Muber } \\
\text { of } \\
\text { meaters }\end{array}$} & \multicolumn{3}{|c|}{ For 1002 now } & \multicolumn{3}{|c|}{ Fr.z 102 flor } & \multirow{3}{*}{ 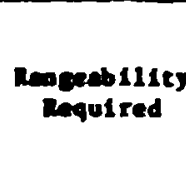 } \\
\hline & \multirow{2}{*}{$\begin{array}{c}\text { Cv, Valve } \\
\text { confficteate }\end{array}$} & \multicolumn{2}{|c|}{ Now tete } & \multirow{2}{*}{$\begin{array}{l}c_{p} \text {, velve } \\
\text { confticient }\end{array}$} & \multicolumn{2}{|c|}{ Mov Rate } & \\
\hline & & (kw/eac) & $(1 b / \mathbf{s e c})$ & & (kg/sec) & (1b/sec) & \\
\hline 91 & 176 & 2.77 & 6.1 & 6.4 & 0.277 & 0.61 & 27 \\
\hline 61 & 117 & 1.86 & 6.1 & 4.7 & 0.186 & 0.61 & 25 \\
\hline 37 & 71.2 & 1.13 & 2.5 & 3.2 & 0.113 & 0.25 & 22 \\
\hline 19 & 36 & 0.57 & 1.25 & 2.0 & 0.057 & 0.125 & 18 \\
\hline $127^{b}$ & 36 & 0.56 & 1.23 & 2.0 & $0 . n 56$ & 0.123 & 18 \\
\hline
\end{tabular}

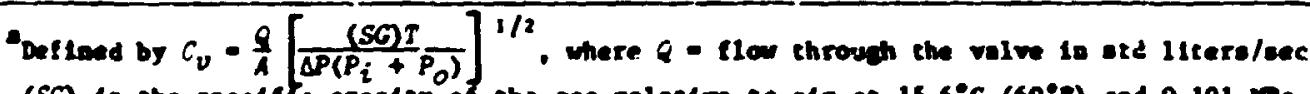

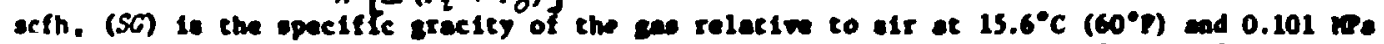

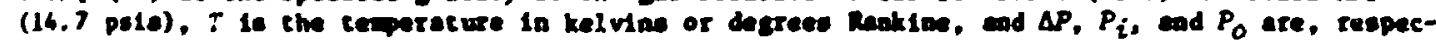
tively, the preenure drop, lalet preseure, and outlet preasure in pescals or pals. The constent

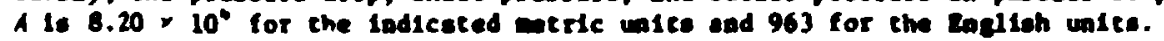

$6.41 \mathrm{~g} / \mathrm{eac}(35 \mathrm{~b} / \mathrm{hr}$ ) par blaaket hearer. 
The rangeability requirements to control the flor transients for various cominations of test bundles and the characteristics of a comercially avallable valve are compred in Table 2.10. The axdman valve coefficient of 174 and the anime of 2 yield a rangeability of 87. which is deened to be too large for a single valve with only one set of trin.

The comercially available valve having a mxinum valve cuefficleat of 195 and used over a rangeabilicy of 60 , which is thought to be a reasonable value, will provide flow transient control for both the 91and 61-heater test bundles. The sase valve aith a special set of trin installed having a maxim valve coefficient of 75 and a rangeability of 60 will control the flow transients in the 37- and 19-heater bundles and the 127-heater blanizet bundle. We favor this valve and the two sets of trin.

Table 3.10. Valve Requitenents and Characteristics

\begin{tabular}{lll}
$\begin{array}{l}\text { Range of } \\
\text { Nubbers } \\
\text { of Heaters }\end{array}$ & $C_{v}$, Valve Coefficient \\
\cline { 2 - 3 } & Maximum Manimeability
\end{tabular}

Combined Requirements

\begin{tabular}{|c|c|c|c|}
\hline \\
\hline 91 & 174 & 6.4 & 27 \\
\hline 91 and 61 & 174 & 4.7 & 37 \\
\hline $91-37$ & 174 & 3.2 & 54 \\
\hline $91-19$ & 176 & 2.0 & 87 \\
\hline \multicolumn{4}{|c|}{ Characterist1cs of Comercial Valve } \\
\hline 91 and 61 & 195 & 3.3 & 60 \\
\hline 37 and 19 & 75 & 1.25 & 60 \\
\hline
\end{tabular}

The speed of valve stem wovement for the fast flow transients epecifted by GA will require the use of hydraullc valve operators having a spool valve actuated by an electromechanical valve. The electromechanical valve will recelve an electrical sigmal from a servo amplifier. The valve stem position will be fed tc the servo applifier so that the 
desired valve stee position and the actual valve sten position can be compared. The signal to the electromechanical valve will be changed as necessary by the servo aplifier to make the actual and desired valve stem positions coincide. The control signal to the servo acplifier will cone from the transient controller.

Speciffcations have been written for the heliun flow control valves, the hydraulic fluid, and the 20.?-\$Pa (3000-psi) hydraulic fluid supply systen.

\subsubsection{Transfent Controller Systen - M. J. Roberts and W. E. MHller}

The transient operation of a:l proposed test bundle porer supplies; the coolant hellu values that control flow to the test bundle, the attemperation path, and the circulator bypass; and the valves that control cooling air flow to the heat exchangers will be controlld with a programable read-only memory (PROM) function generator (PFG). This syster will be programed to produce the several transients and repetitive cycles requited for the CFTL. The PFG has urdergone three stages of development. The latest of these is now being fabricated to provide the control fuxctions for the Cril seven-heater water test.

The PFo is block-diagramed 1n Fig. 3.24. An electronic clock, whose frequency is selectable by the user, increments a binary counter. The 8-bit binary nuber frow the counter consecutively addresses the memory locations as it is incremented. As the address is incremented, the 8-bit binary data from the PROM change according to the function stored in the PROM. These data can be used in binary form or converted to an analog voltage or current to be used as a control set point for a process.

\subsubsection{High-Speed Rata Acquiaition System - C. D. Martin, J. L. Redford, and H. J. Metz \\ The maximum frequency during transients for nearly all test section measurements as Indicated in the GA Program Plan is one per second except that hundle power measurenents are taken ten times per second during a transient. However, in our opinion, verification that a CFTL fast tran- sient duplicates somewhat faithfully the dara indicated in GA's,}




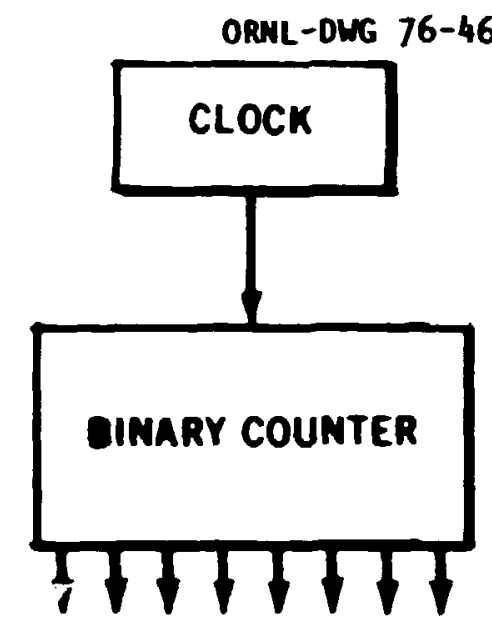

8-BIT BINARY

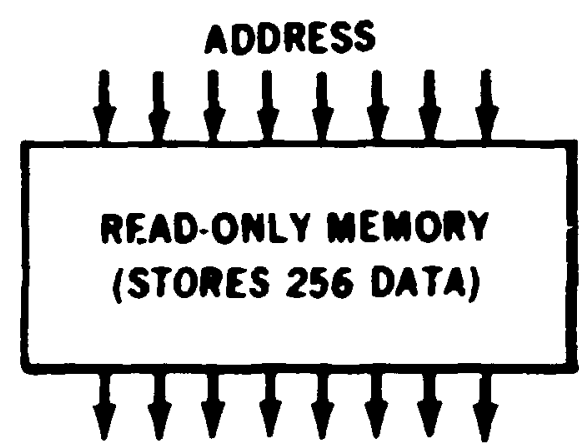

8-BIT BINARY

DATA

(RESOLUTION IS

1 PART IN 256)

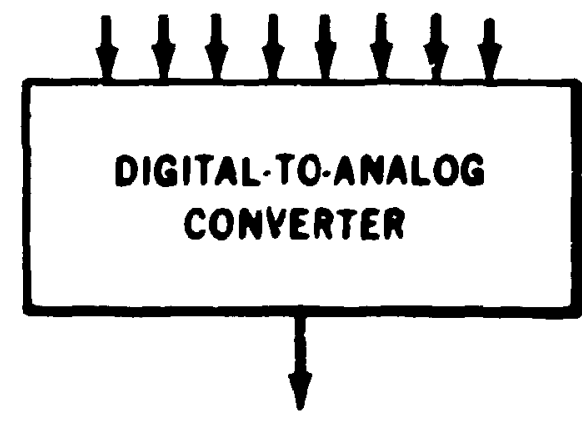

quantized analog

OUTPUT

(VOLTAGE OR CURRENT)

P1g. 3.24. Programmble Read-Only Memory Punction Generator for Controlling Transient Operation of CFIL. 
"Transfent Data for GCFR, Gravity and Shutdown Data from MAXGAF Calculatfons," will require many Eeasurements of several important parameters to be made during the transient. These masurements include tentatively zest bundle electrical power, helfin flow rate through the test bundle, test bundle fnlet and outlet heliu pressures and tesperatures, test bundle differential pressure, and heater sheath texperatures. An additional complication to the control and measurement of test bundle power is the lower spectfic hea: of the bundle simulators compared with a GCFX iuel rod. This will requize odifying bundle power input from the values for GCFP. core power shown in the MAXCAF tables $\approx$ attain on the CFTL heater cladding the same tesperature values the GCFR rod cladding experiences, particularly during fast transients. Verification of the heacer cladding temeratures will require a number of measurements per second during transients.

Frequent and accurate masurements taken during the transfents will perwit both GA and ORNL to assure the USNRC, and also possible intervenors, that the CFTL cest conditions indeed do duplicate these anticipated with the GCFR.

Figure 3.25 shows a block diagram of the Hign-Speed Data Acquisition Sysiem (HSDAS) that has been selected tentatively for the CFTL. It will accept 640 inpur channels of measur ments and can be increased to 1024 channels by installation of additional 128-channel modules. During fast transients the HSDAS can record data on magnetic tape at the rate of 20,000 channels per second continuously for up to $200 \mathrm{sec}$ and provide stmultaneous limit checking for alarms and shutcown initiation. During steady-state and slow-transient test operations, all signals will be recorded on magnetic tape and limit checked for alarm and shutdown initiation periodically, and the HSDAS will also provide on-line real-time calcularion and display of some system operating condicions. The computer used in the HSDAS will be able to provide the experimenter with a compretensive analysis of previously acquired data in an off-line mode of computer operation.

We investigated methods of masuring efther ac or dc test bundle power. The most feasible method appears to be the use of shunts to 


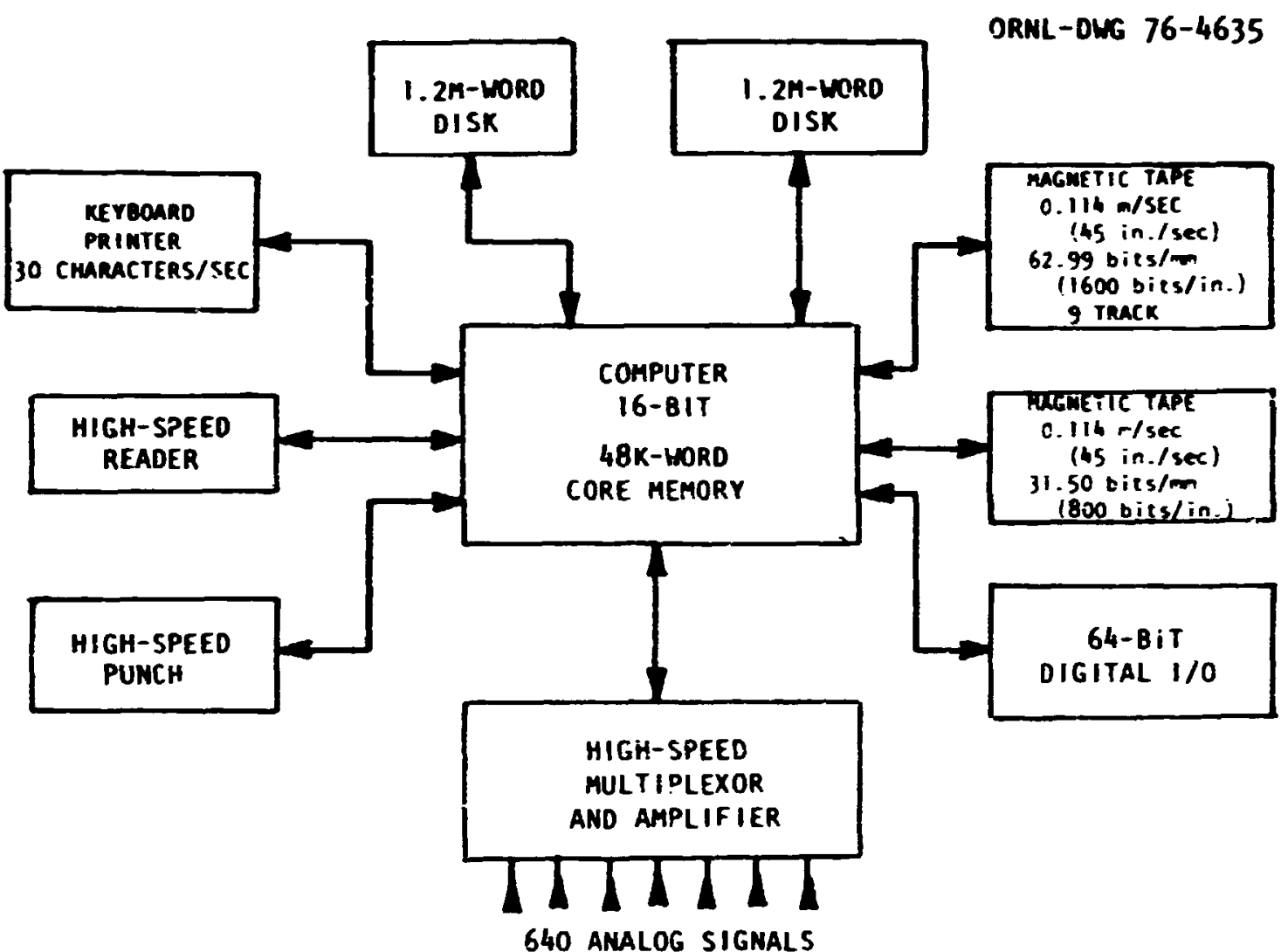

F1g. 3.25. Block Diagram of High-Speed Data Acquisition Systed for CFTL.

measure current and the utflization of the computer to calculate power from voltage and shunt output measurements.

\subsubsection{Studies on Insuiation Effects in Small-Diameter Thermocouple Material - R. L. Anderson and T. G. Kollle}

Small-dian:er 0.51 (0.020 in.) sheathed therwocouple merials are used in simulation tests of reactor fuel rods for both the LMFBR and the GCFR. The stringent requirements on the temperature measurements for these tests and the relatively recent availability of 8 mall thermocouple materials indicated a seed to measure the insulation properties of these materials, particularly considering the small diameter of the materials and the relatively high temperatures involved. In the course of the investigations, a nimber of effects were investigated related to the reliability of small-diameter thermocouples. 
A fairly "typical" exaple of the insulation resistance (IR) versus temperature is shown in Fig. 3.26. "Typical" in this case carries a nuber of qualifications. This curve my be produced only after several temperature cycles. For exalple, Fig. 3.27 shous the data taken on a 0.51-m-dian (0.020-in.) thernocouple beginning with its "as received" condition through four thermal cycles. On the first heating cycle, the IR sharply decreases at about $100^{\circ} \mathrm{C}$. The sane effect, see Fig. 3.28, has been observed in larger diameter aterials by Horton et al. ' and is belleved to be due to release of the water absorbed on the MgO insulation.

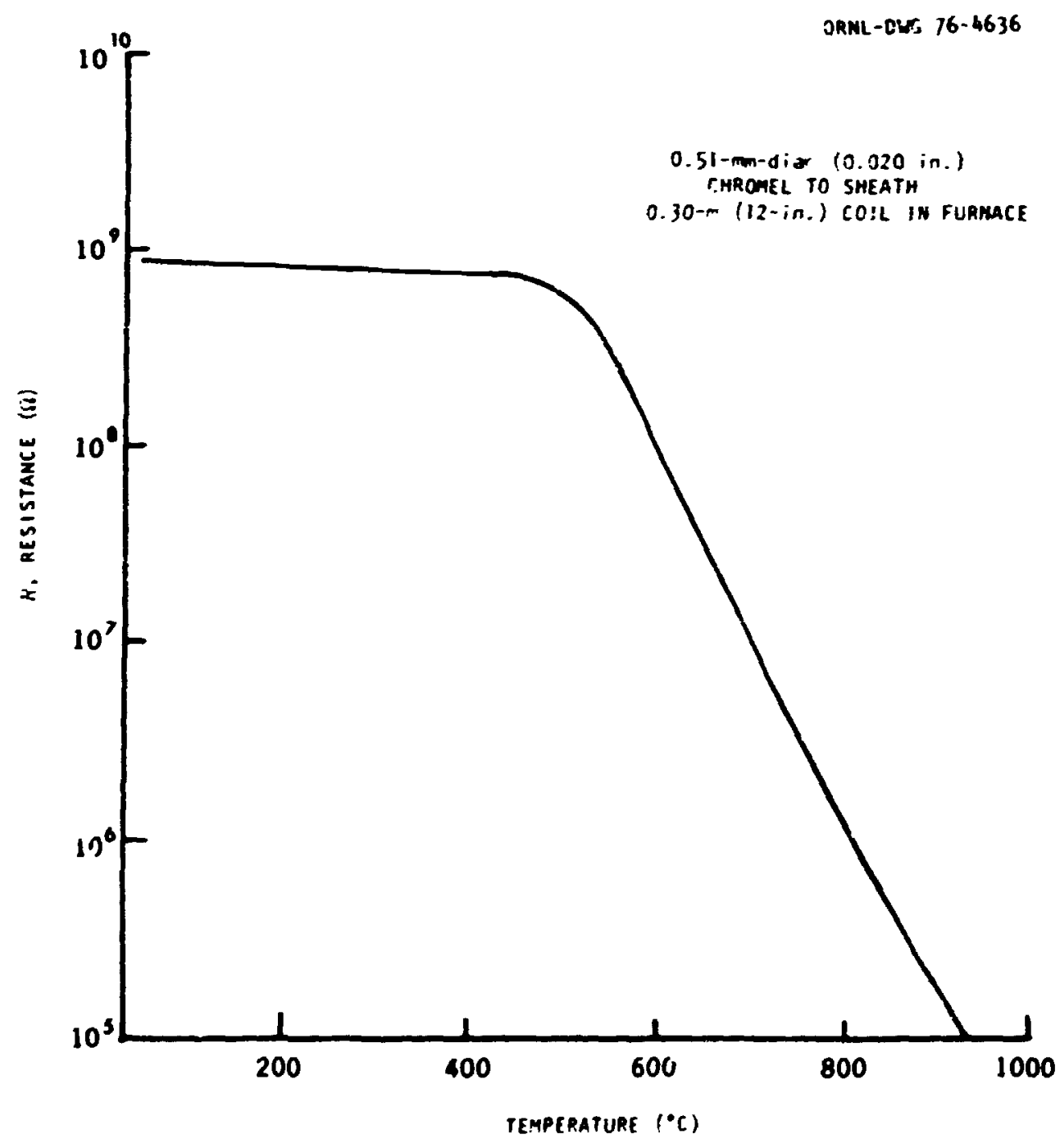

Fig. 3.26. Typical Insulation Rasistance us Temperature for Sma11Diapeter Sheathed Thernocouple Material. 


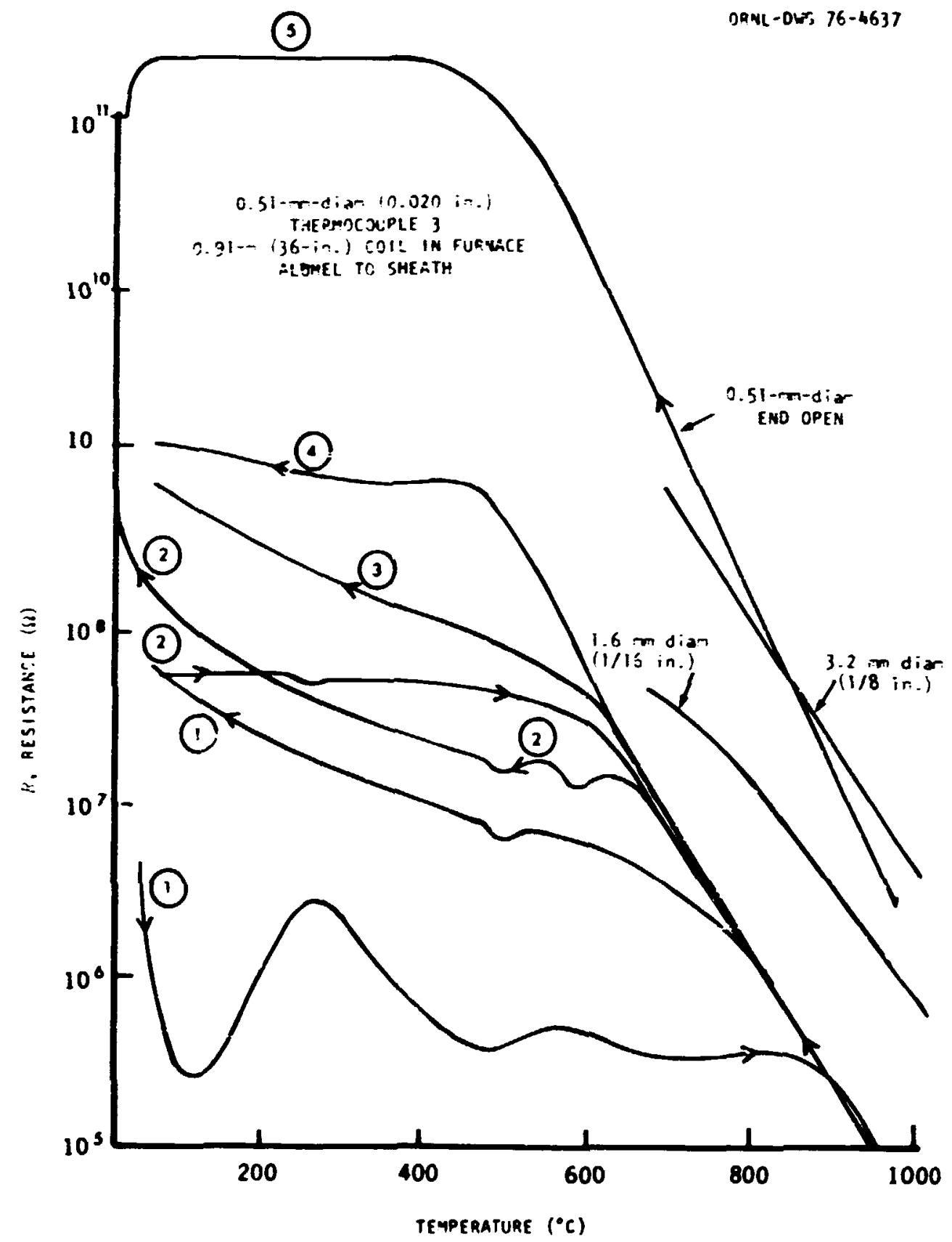

F1g. 3.27. Insulation Resistance Versus Temperature for 0.51-mdiam (0.020 in.) Thermcouple Material Beginning with As-Recelved Condition through Four Heating and Cooling Cycles. Curves 1 through 4 represent these cycles; only the cooling pk:tion 18 show for cycles 3 and 4. Curve 5 shows simflar material with the hot end al removed to ease escape of water vapor. High-temperature portions of curves a:e shown for larger diameter material. 


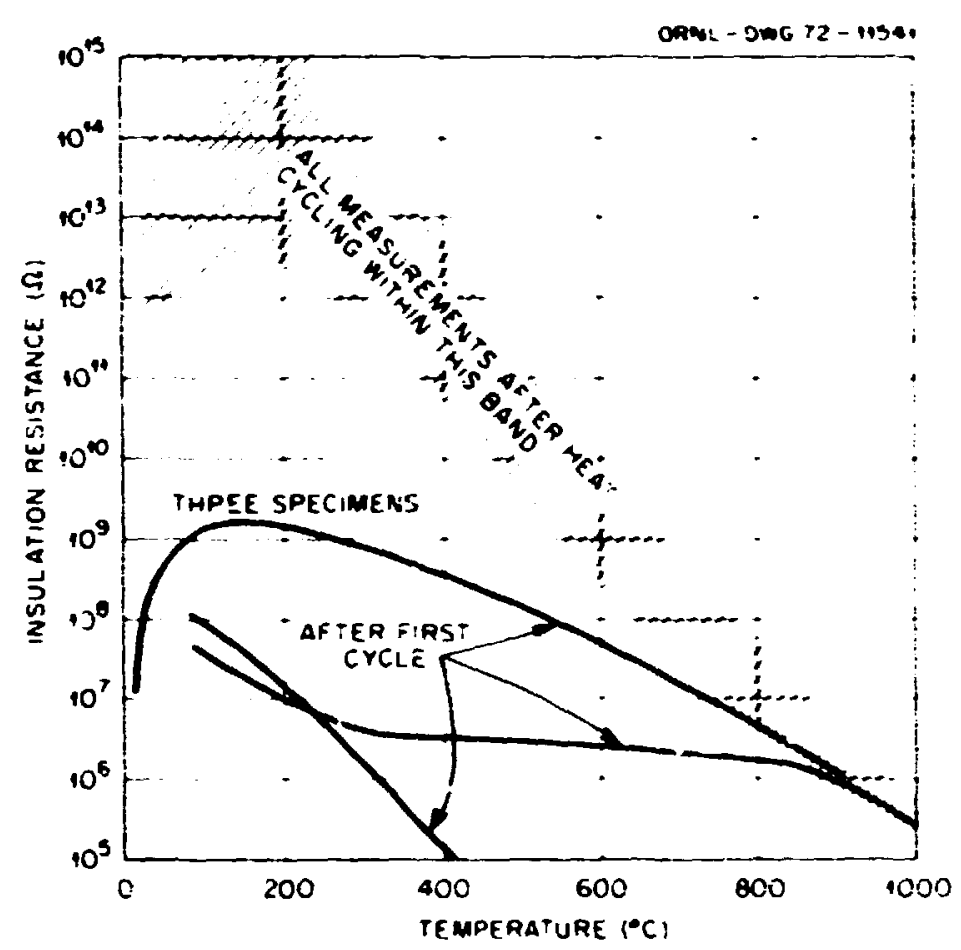

Fig. 3.29. Insulator Resistance vs iemperature for Nine 0.125-in.OD Specimens.

Figure 3.29 shows the effect of temperature on the adsorption of water on MgO. High-temperature processing of the insulation materia) is obviously necessary to remove the absoroed water, which is most likely not done in the manufacture of these materials. When one zone of thermocouple material is heated to high temperatures (up to $1000^{\circ} \mathrm{C}$ ), the adsorbed water in the heated zone will be released and diffuse to the cooler portions near the ends of the furnace. This process can be observed in Fig. 3.27 in going from heating cycles 1 through 4 . The IR represented by curve 4 is fairly stable and reproducible, provided the temperature gradient is not shifted along the thermcouple. If a fresh previously unheated section of the thermocouple is moved ints the furnace, then the IR again behaves like the first heating in curve 1 .

If the end seal of the thermocouple in the hot zone is cut of 80 that the water vapor is free to escape, a much higher IR can be obtained, as shown in curve 5 on Fig. 3.27. The droop at the cold end shows that as the temperature of the system falls below about $100^{\circ} \mathrm{C}$, water begins 


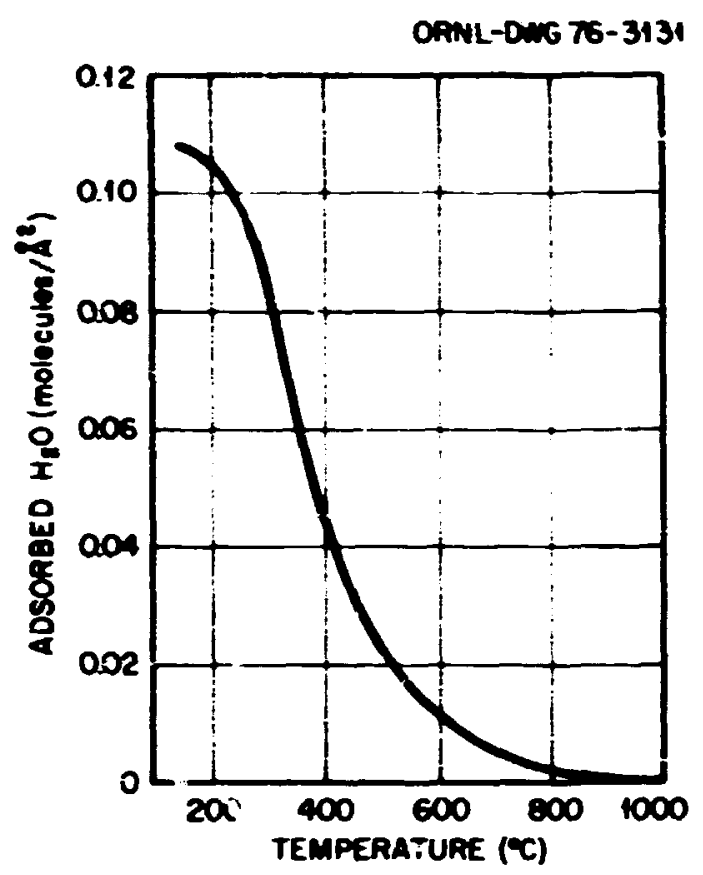

Fig. 3.29. Residual Adsorbed Water on MgO After Prolonged Pumping at Various Temperatures. Based on P. J. Anderson and P. L. Morgan, Trans. Faraday Soc. 60: 930-37 (1964).

to readsorb and iower the IR. Also plotted in Fig. 3.27 for comparison are the high-temperature portions of the measured IR of materials with diameters of 1.59 and $? .17=(1 / 16$ and $1 / 8 \mathrm{1n}$.).

there is sore evidence that the value of the IR is veltage dependent, so that the values measured typically at 10 or $50 \mathrm{v}$ ma be cuite different from an effective IR for thermocouple voltages in the inillivolt range. This effect has not been extensively investigated.

Experiments at higher temperatures and with larger diameter materials have show serious errors (up to $400^{\circ} \mathrm{C}$ ) because of insulation shunting ans establishmet of "virtual junctions" when portions of the therwocouple assembly are at higher temperatures than the measuring function. Ine expertwetit stown in Fig. 3.30 was set up to check this effect in

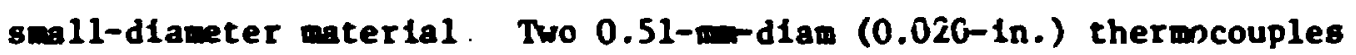
were placed in a furnace with their functions tied together. A 1-w portion of one thermocouple was colled and run through a second furnace, while the second thermocouple was left at room temperature outside the second 


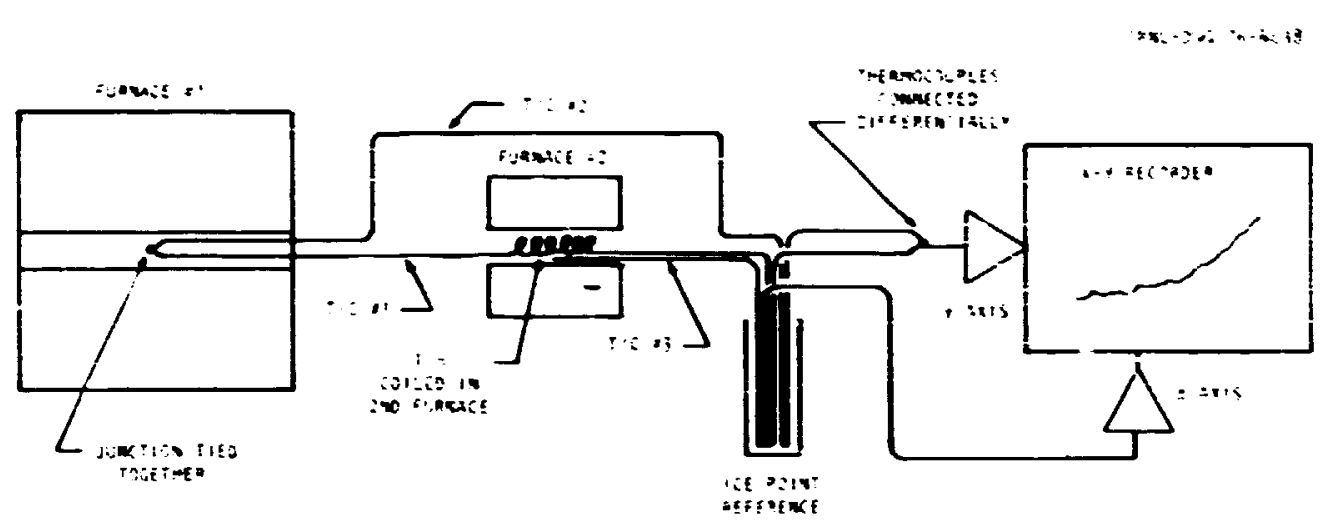

Fig. 3.30. Schematic of Experiment to Measure Error Resulting from Establishment of "Virtual Junction" Caused by Insulation Shunting when Portions of Thermocouple Assembly Are At Higher Temperature Than tine Measuring Junction.

furnace. The two thermocouples were connected together differentially and then connected to the $y$ axis of an $x-y$ recorder. A third thermocouple was placed in the second furrace to read the temperature of the hot zone and connected to the $x$ axis. With the test thermocouple junction at various temperatures in the first furnace, the hot-zone temperature in furnace 2 was varied, and the results were plotted by the recorder. These results are shown in Fig. 3.31. The results indicate a maximum potential error up to $36^{\circ} \mathrm{C}$ with the second furnace at $1100^{\circ} \mathrm{C}$ and the first at roow temperature.

An additional effort was made to elucidate this phenomenon with the experimental setup show in Fig. 3.32. Two 0.51-mm-diam (0.020-10.) type $K$ sheatlied tiermocoupies were mounted inside a quartz tube installed Instde a furnace, one the rwocouple erieing from elther end of the furnace. About $80 \mathrm{~mm}(3 \mathrm{in}$.) of the ends of each thermcrouple was coiled, and the junctims were tied together with a ball of platulum wire. Two type S ( $\mathrm{Pt}-10 \% \mathrm{Rh}$ vs $\mathrm{Pt}$ ) thermocouples insulated with alumina beads were also attached to the platinum ball. As with the type $K$ thermocouples, one type, $i$ couple was led out either end of the furnace. The thermocouple assembly was sealed in a quartz tube. which had been purged with flowing helium to reduce the oxidation of the thin slainless 8 teel sheaths at elevated temperatures. 


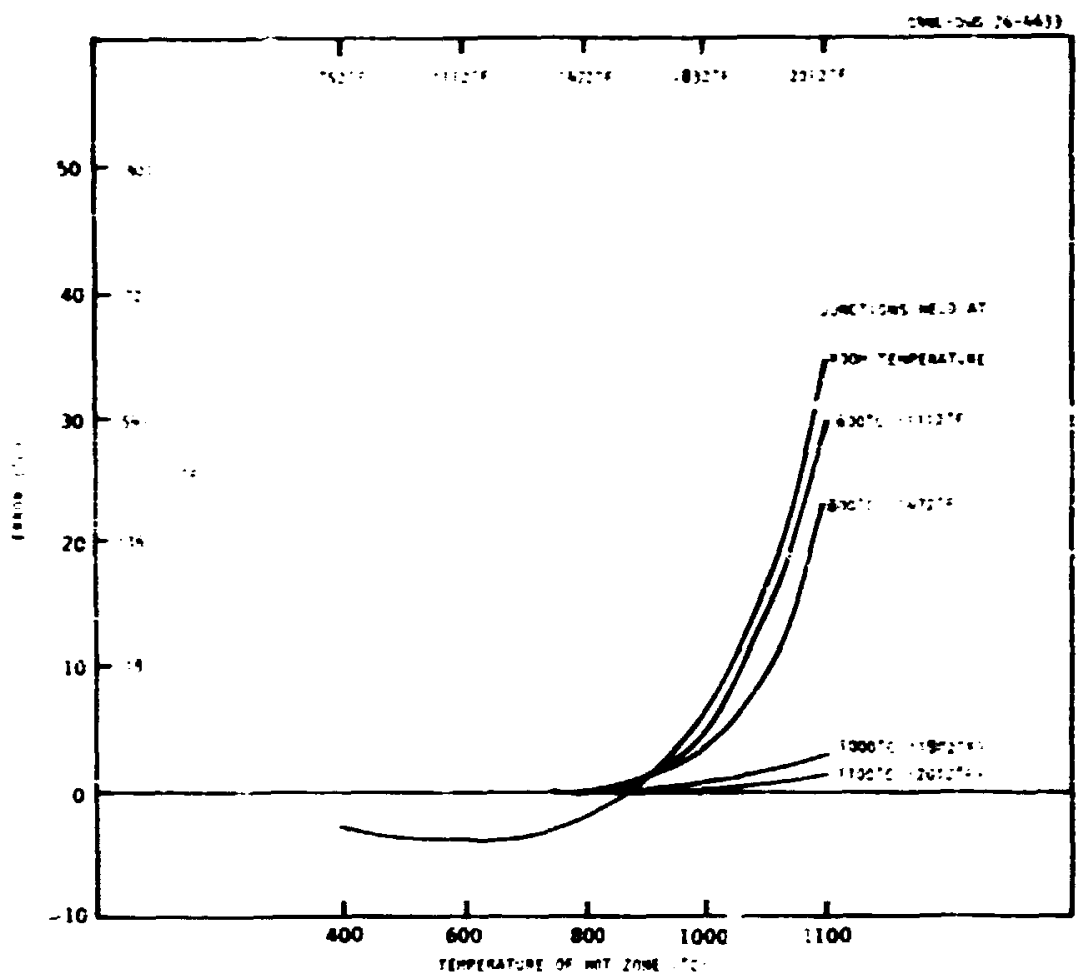

Fig. 3.31. Thermocouple Error Caused by Heating Portion of Thernocouple Assembly with Thermocouple Junction Held at Several Different Constant Temperatures.

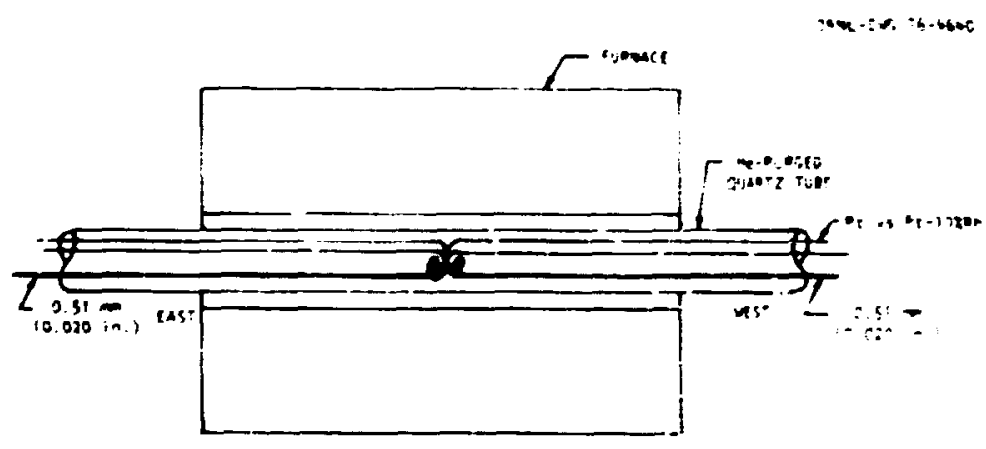

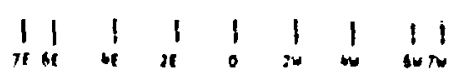

F1g. 3.32. Experimertal Arrangement for Measuring Thermocouple Readout Error Due to Position in Purnace. To 0.51-mo $(0.020-1 \mathrm{n}$.) type $K$ sheathed test thermocouples and two type $S$ thermocouples insulated with alumina beads are attached to a platinum ball, and the therwocouple junction region is sealed in 3 quartz tube. The quartz tube is then slid in and out to scan the temperature variotion in the furnace. 
The results are sinown in Fig. 3.33. The curves are the oifferences indicated by the type $K$ therwocouple and the average of the two type $S$ thermocouples. The two type $S$ therwocouples agreed with each other within about $2^{\circ} \mathrm{C}$ thrcughout the experinent. The furnace was scanned by noving the therwocouple assembly in the quartz tube right or left by measured amounts, so that the thernocouples vere placed in various parts of the temperature gradients in the furnace. At $600^{\circ} \mathrm{C}$, the two type $\mathrm{K}$ thermocouples agreed to vithin $4^{\circ} \mathrm{C}$ at all positions in the furnace. At $800^{\circ} \mathrm{C}$, however, one of the therwocorples began to show large $\left( \pm 6^{\circ} \mathrm{C}\right)$ deviations fron the temperature measured by the type $S$ thermocouples. In Fig. $3.33(\mathrm{c})$ the results of twn scans made at $1000^{\circ} \mathrm{C}$ indicate that deviations are larger (up to $30^{\circ} \mathrm{C}$ ) than at $800^{\circ} \mathrm{C}$ and much greater in the second run than in the first, indicating time dependence also.

After completion of the experiment in the furnace, the the rmocouples were disassembled and tested in the instrumentation and Controls Division howogeneity test rig. The results in Fig. 3.34 show that the high terperatures caused significant changes in the thermoelectric materials thewselves, with about twice the effect occurring in the Chromel leg. He believe that the effect is due to the oxidation of the very sall [0.076-0.127 diam $\left.\left(0.003-0.005-i_{.}\right)\right]$wires, since a similar test on 1.59-mor-diam (1/16-in.) materials showed little effect.

This experiment shows that the large errors can occur when the tewerature gradient changes along the tilermocouple after it has seen high-temperature service. With the assembly in the center of the furriace, the type $K$ and the type $S$ thermocouples agree fairly vell.

These studies have indicated that the small-diamet $2 r$ type $K$ thermocouples can be considered fairly reliable up to $600^{\circ} \mathrm{C}$ if certain precautions are taken. To extend the range of these sensors, a proposition of doubtful werit considering the inadequacies of the Chromel-Alumel materials themselves, further studies will have to be conducted on ways to reduce the development of the large inhomogeneities in the temperature gradients. The shunting due to the decreasing IR does not appear to present a serious, roblem even up to $1000^{\circ} \mathrm{C}$ for relatively modest loop resistances. As the loop resistance of the thermocouples become large, the IR shunting can again become a problem. 
ORHL-DUG 76-464I
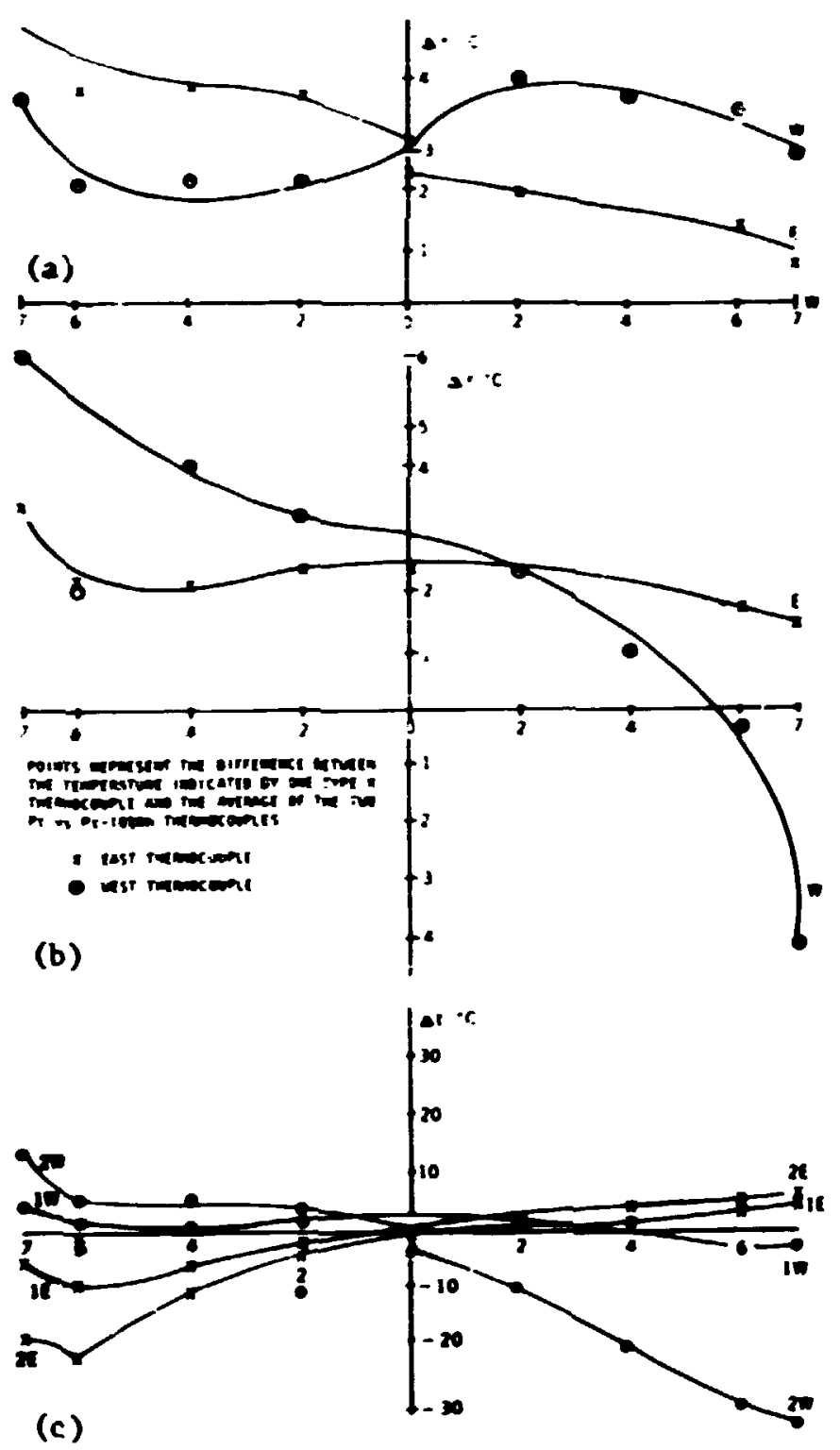

F18. 3.33. Differences in Temperatures Indicated by Individual Type $R$ Thermocouples and Averages from Two Pt vs PC-10\% Rh Therecouples as Measured in the Experiment Shown in Fig. 3.32. The horizontal axis represents fumace positions as show in Fig. 3.32. (a) First scan at $600^{\circ} \mathrm{C}$. (b) First scan at $800^{\circ} \mathrm{C}$. (c) First scan at $1000^{\circ} \mathrm{C}$ and second scan 24 hr later. 


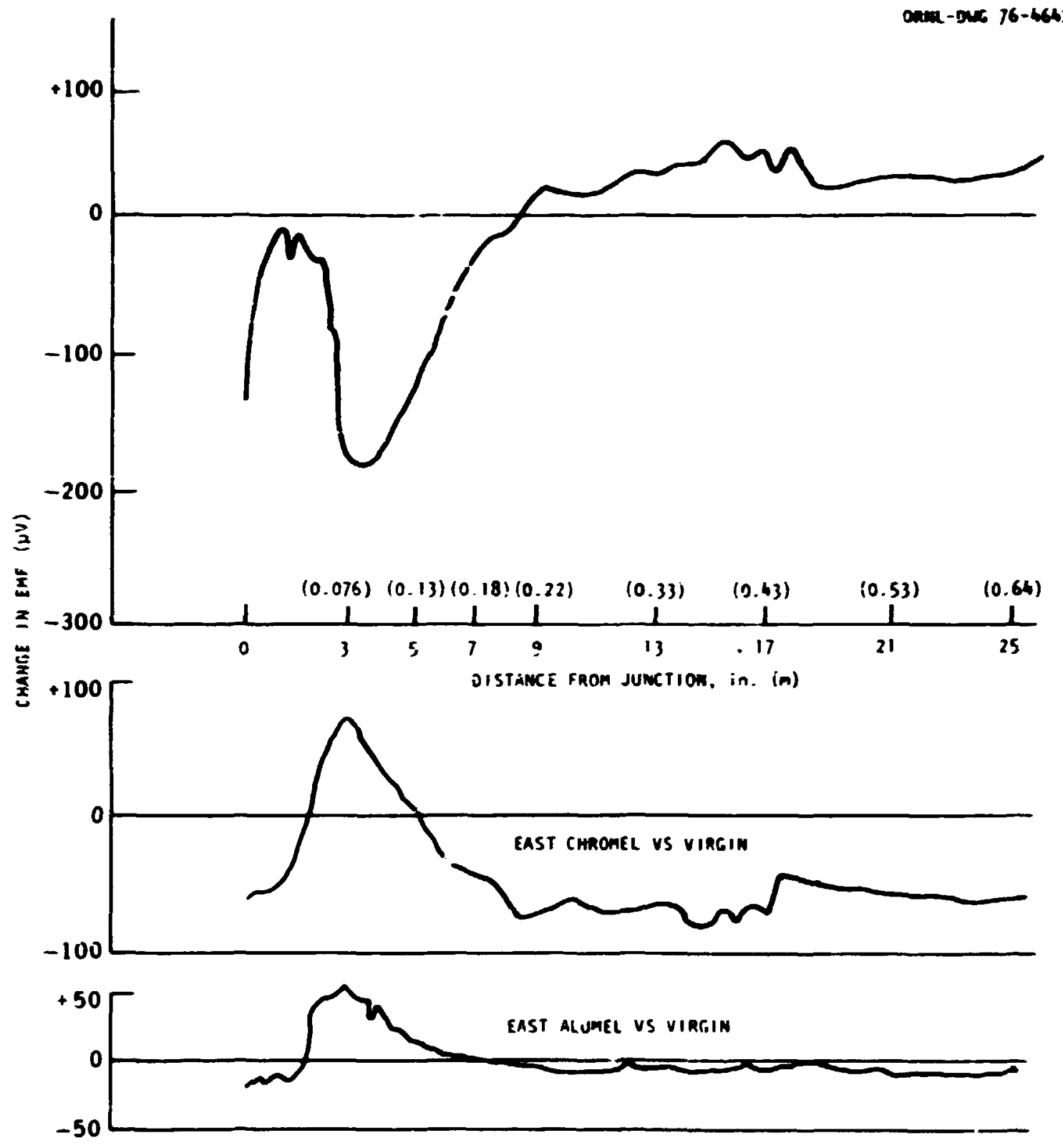

P1g. 3.34. Inhonogeneity Test Conducted on East Thermocouple After Completion of Tests in Experisental Arrangement Show In Pig. 3.32. 
3.7.6 Thernocouple Noise in AlEemating Hernetic Fields - D. U. MeDorald and M. J. Roberts

We undortook an investigation into the effects upon thermocouple readings of the electromgnetic interference (ead) generated by a candiate CFTL power supply. The results indicated that en would not be a problen, and that if the lowest frequency output of the pourer supply is near $60 \mathrm{~Hz}$, with filtering and a carefully designed grounding systea the effects of the interference will be animal. However, without filtering the output of therrocouples that use ferromgnetic thernoelements will be contanated with a series node ac nolse voltage having an aplitude proportional to the angnitude of the ac current of the power supply and inversely reiated to the terperature of the thernocouple, and a lowest frequency component equal to the lowest frequency of the power supply. The ac nolse voltage wave form consists of sharp spikes. The aplitude of these spikes ay attain levels equivalent to a $27.8^{\circ} \mathrm{C}$ $\left(50^{\circ} \mathrm{F}\right)$ error for a $60-\mathrm{Hz}$ power supply and $126^{\circ} \mathrm{C}\left(227^{\circ} \mathrm{F}\right)$ error for a phase-fired power supply if the spike and data systen input coincide. However, since the spikes are very narrow and the data systea and spikes wil coincide randonly for an individual thernocouple, an average or nes value better indicates the actual experienced error at the output of a measuring device die to this notse. An res error of $\left(.34^{\circ} \mathrm{C}\left(0.7^{\circ} \mathrm{F}\right)\right.$ for the former and a ras error of $1.7^{\circ} \mathrm{C}\left(3^{\circ} \mathrm{F}\right)$ for the latter are nore typical of the error one ay expect. These seeningly seall errors ast be considered 81 gnificant since $1.7^{\circ} \mathrm{C}$ is $20 \%$ of the total error allowed, and other errors due to the thernocouple properties and the CFIL data acquisition systen have not jet been fully analyzed. With filtering, these mesured errors can b.: reduced significantly.

We measured emi nolse in 1 wockup of a CFTL heater rod. The experimental setup for measuring the noise cue to the electric field is shown In F18. 3.35. The therwocouples tested include 0.51-m-0D $(0.020-\mathrm{in}$. stainless-steel-sheathed magnesium-oxide-insulated Chromel vs Alumel the rwocouples, 0.38-OD (0.015-in.) Individually sheathed Chromel and Alumel wires, and 0.51-m-OD (0.020-in.) stainless-steel-sheathed Nisil vs Nicrosil thermocouples. The voltage between the heater element and the heater sheath was varied from zero to over $130 \mathrm{~V}$. This variation 


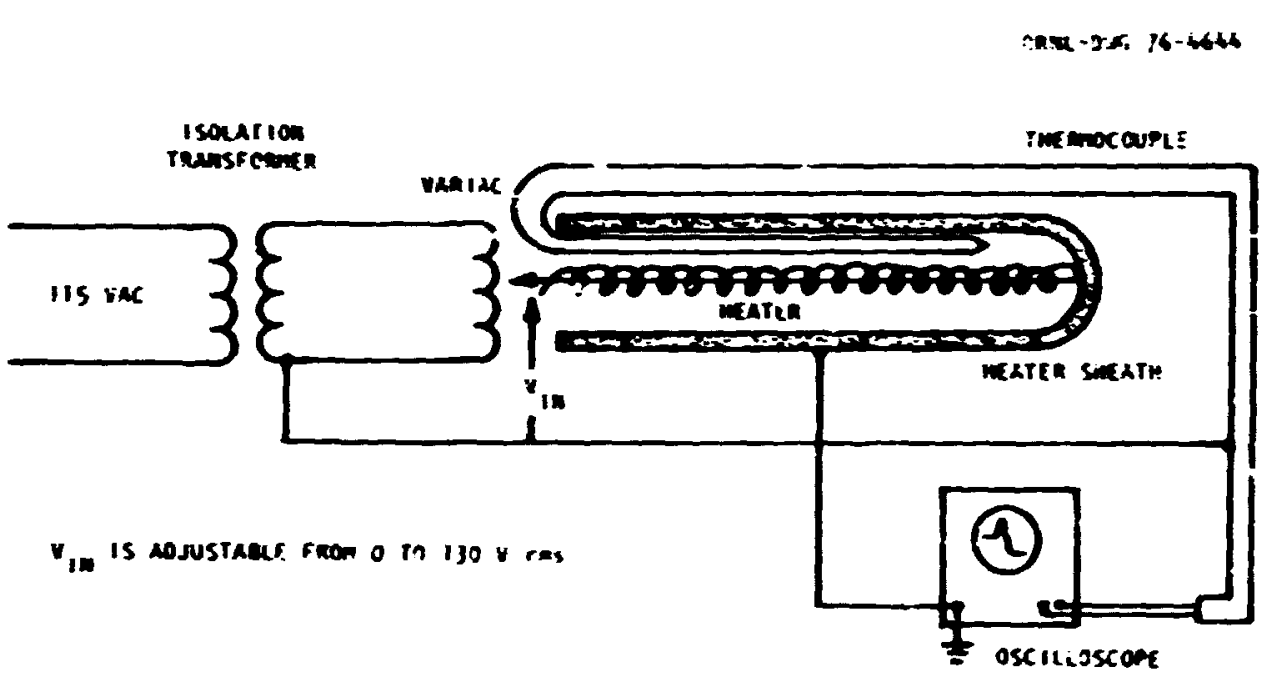

Fig. 3.35. Heasurement of Noise Induced in a Thinecouple by an Alternating Electric Field.

caused an altermating electric field across the thermocouples. No noise could be detected at the therwocouple output because the type 304 stainless stgel sheaths provide a good shield for electric fields.

The experimental setup for measuring the noise due to the manetic field is shown in Fig. 3.36. The same thernocouples were used in boch tests. The alternating current through the heater element vas varied from :ero to over 125 a ras. This caused the thernocouples to be in an alternating mgnetic field. This resulted in only slight noise at the output of the Misil ve Microsil thernocouple, approximately $10 \mathrm{\mu V} \mathrm{ns}$, wich is equivalent to an instantaneous error of $0.17^{\circ} \mathrm{C}\left(0.31^{\circ} \mathrm{F}\right)$. Both types of Chromel ve Alumel thernocouples produced a large-amifitude noise, approximtely $\mathrm{l} \mathrm{w}$, which is equivalent to $17^{\circ} \mathrm{C}\left(31^{\circ} \mathrm{F}\right)$ error at the peak of the noise spikes. Continued investigation revealed that interaction between the ferromagnetic Alumel and an altemating agnetic field generates a serfes-wode noise voltage. The amplitude is directly related to the amplituje of the current inducting the magnetic field and inversely related to the thermoelement temperature. The amplitude approaches zero as the temperature approaches the Curie temperature of the thermoelement, whici is $134^{\circ} \mathrm{C}\left(364^{\circ} \mathrm{F}\right)$. The noise voltage from NisilNicrosil was negligible because 11 . Curic temperature of $\mathrm{Nisil}$ is $25^{\circ} \mathrm{C}$ $\left(77^{\circ} \mathrm{F}\right)$. Noise wa.s generated in Nisil when it was cooled below the curie temperature. 


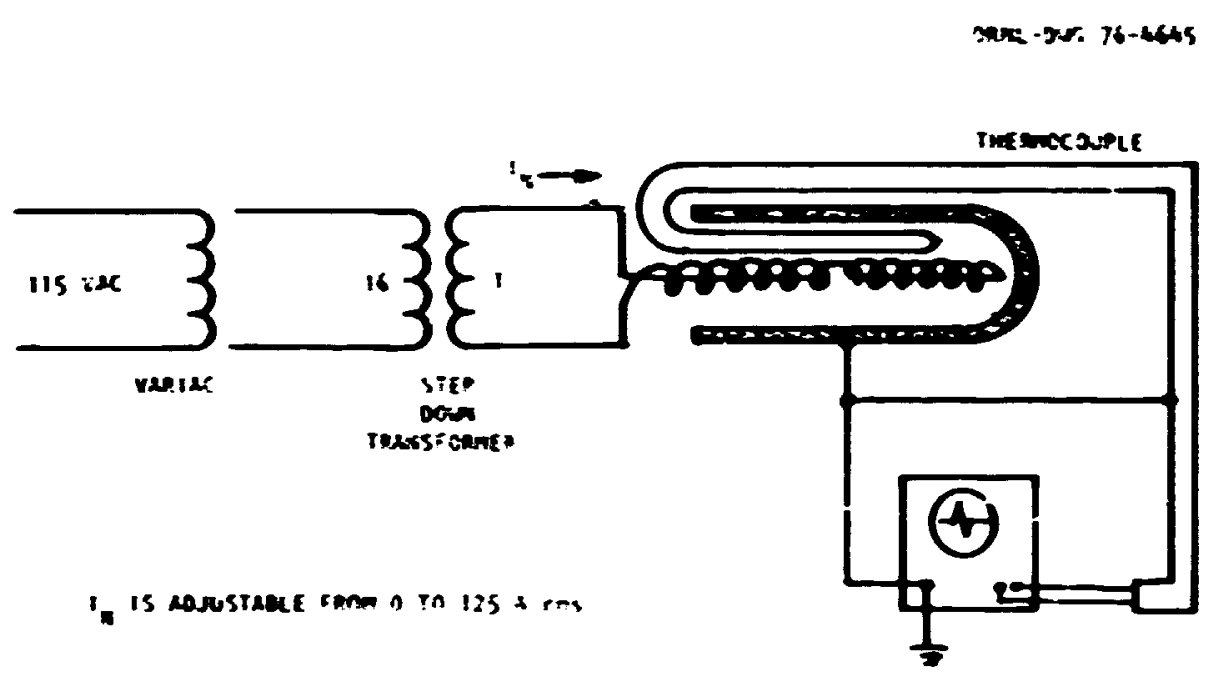

Fig. 3.36. Heasurement of Hoise Induced in a Thernocouple by an Altermating Hagnetio Field.

The aplitude of this "menetic ef fect" is extrenely sensitive to spatial orfentation. A nolse output of $707 \mathrm{\mu V}$ was decreased to $56 \mathrm{\mu V}$ by rotating the thermelement slightly. The output of the $0.38-$ an (0.015-in.) Individually sheathed thermelenent Chromel vs Alunel therwocouple revealed 60-Hz pickup as well as the "menetic effect" noise. Because the individual therwelemes zere not close togetner, the loop thus forned was picking up the $6 \mathrm{C}-\mathrm{llz}$ agnetic field. The experinent was reassembled with the distance between the thermolemeats kept to the anime. Then the noise pickup was almost elfinated.

In all the monetic field tests, agetic shielding eterial was wrapped around the therwocouple outside the heater sheath to elininate extraneous effects. Without the shielding, the "mgnetic effect" remins even though the thermolewent within the heater is above the Curie temperature. The mgnetic field exists outside the heater and Interacts with the Aluml, which is at room temperature outside the heater.

i $90^{\circ}$ phase-fired current from a silicon controlled rectifier (SCR) was fed to the heater. Below the Curie temperature the thermocouple outputs were extremely nolsy. Voltage spikes were over $5 \mathrm{mV}$, which is equivalent to an Instantaneous error of $126^{\circ} \mathrm{C}\left(227^{\circ} \mathrm{F}\right)$. Above the Curie tesperature, the noise becale an instgnificant $0.64 \mathrm{uV} \mathrm{ras,} \mathrm{equivalent}$ 
to $0.36^{\circ} \mathrm{C}\left(0.64^{\circ} \mathrm{F}\right)$. These simall spikes were due to residual agnetisn sbove the Curle temperature ans did not decrease with large temperature increases.

Passive, active, and dtatial filters are being investigated. Several breadbairded scherces are being conpared for stability, cost, and size factors. Comercisl filters were ahso investigated and rejected as undesirale for the sfecific CFTL application. The investigation presently centers on several conbined active filters and low-noise preaplifier design s:henes.

\subsubsection{Paver Supplies for the CFTL Test sundles - M. J. Roberts and R. W. Bochelle}

The two areas of power supply type and the filtering wethods for thernocouple signals interact strongly because the frequency of the nolise picked up depends on the frequencies of the porer supply. As the lovest frequency of the power supply becones smaller, the bore dit icult it is to filter out noise when fast transieats mast be recorded. Electromgeric interference frequencies as $10 \mathrm{u}$ as $2 \mathrm{~Hz}$ cannot be removed by filters in a fast-response system.

For a dc heater power supply, the path for interference with the thermocouple output signal is through the conduction of the insulation between the heater and the therwocouple wires. Insulation at CPII test conditious will be a relatively $800 d$ conductor, and there will be large leakage currents inside the heater sheath that will take the wost conductive paths. It is believed that the chances of the allivolt thernocouple sigals surviving uncontaninated by a high dc heater current is quite small. There would be no way to know how euch of the thernocouple output was caused by leakage and how wuch by the hot junction unless the heaters were cumed off and isolated from the temperature measuring system. Therefore the use of de porer supplies is questionable at this tise.

When ac power to the heaters is used the conductance of the insulation is not as serious a problea as for dc power if the leakage currents have a frequency of about $60 \mathrm{~Hz}$. The $60-\mathrm{Hz}$ nolse can be renoved by filtering. The thermocouple response to the heater power cransients 
Where power is reduced fron $100 \mathrm{z}$ to $10 \mathrm{z}$ in about 1 sec is in the frequency band froe 0 to $10 \mathrm{~Hz}$. A filter that rejects $60 \mathrm{kz}$ combined with a filter that will conduct everything below $10 \mathrm{gz}$ will renove the nolse from the therwocouple sigals caused by ac leakage currents.

The ac power to the heaters can be swoothly controlled to supply the required power profile for the transient cests. This cethod would give the least thernocouple nolse problew. Pouer can be supplied by "zero-phase-fired" SCRs. The normal techaique is to delete cjcles to reduce power. A one-cjcle-on and nine-cjcles-off heacer power control we will have a strong composent at $6 \mathrm{kz}$. This frequency 111 be passed through the therwocouple sigmal filter and could cause errors. Another wethod is to wee "phase-fired" Scrs. The frequency spectru vill contaic $60 \mathrm{~Hz}$ and higher frequencles. Little exers will go through the therrocouple signal filter. The steep-sided transieats produced by the "turn on" of the SCR contafn powerful high-frequency comoneats, which pass around filters and are difficult and expensive in senove.

There are sone ac power supply designs that should reduce thernocouple nolse pickup. Three of these are the sutiched secondary systen, the suitched resistance systen, and the antched capacitor systen. The switched secondary supply transforwer secondary uindings have relative voltage outputs of 1, 3, 9, and 27 are connected as shown 1n F1g. 3.37 (a). $A$ winding can be added, suttracted, or disconnected to produce an output voltage from zero to 40 to provide 40 power levels. Power level is plotted against step nuber In F1g. 3.37(b). The largest pover step Is 5\%, and the coatrol becones wo precise as the power is lowerad. Th1s systen has been operated successfully on a laboratory beach scale. The arthed reafotance systen is lllustrated in P18. 3.38(a). The four resistors are related to each other by a factor of $2: R_{n}=2 R_{n-1}$. The solid curve in Fig. 3.38(b) gives the relation between resistors connected and power delivered to the lond. The dotted curve is pouser taken fron the 11ne. Interwadiate average values of power are obtained by tiwe-proportioning witching between the two closest levels. The largest power step is 23.62 just below full 10ad. Figure 3.39 shows how control could be isproved. The madan pover that is diseipated in the resistances is 257 of full load. It occurs at 102 of full load. 


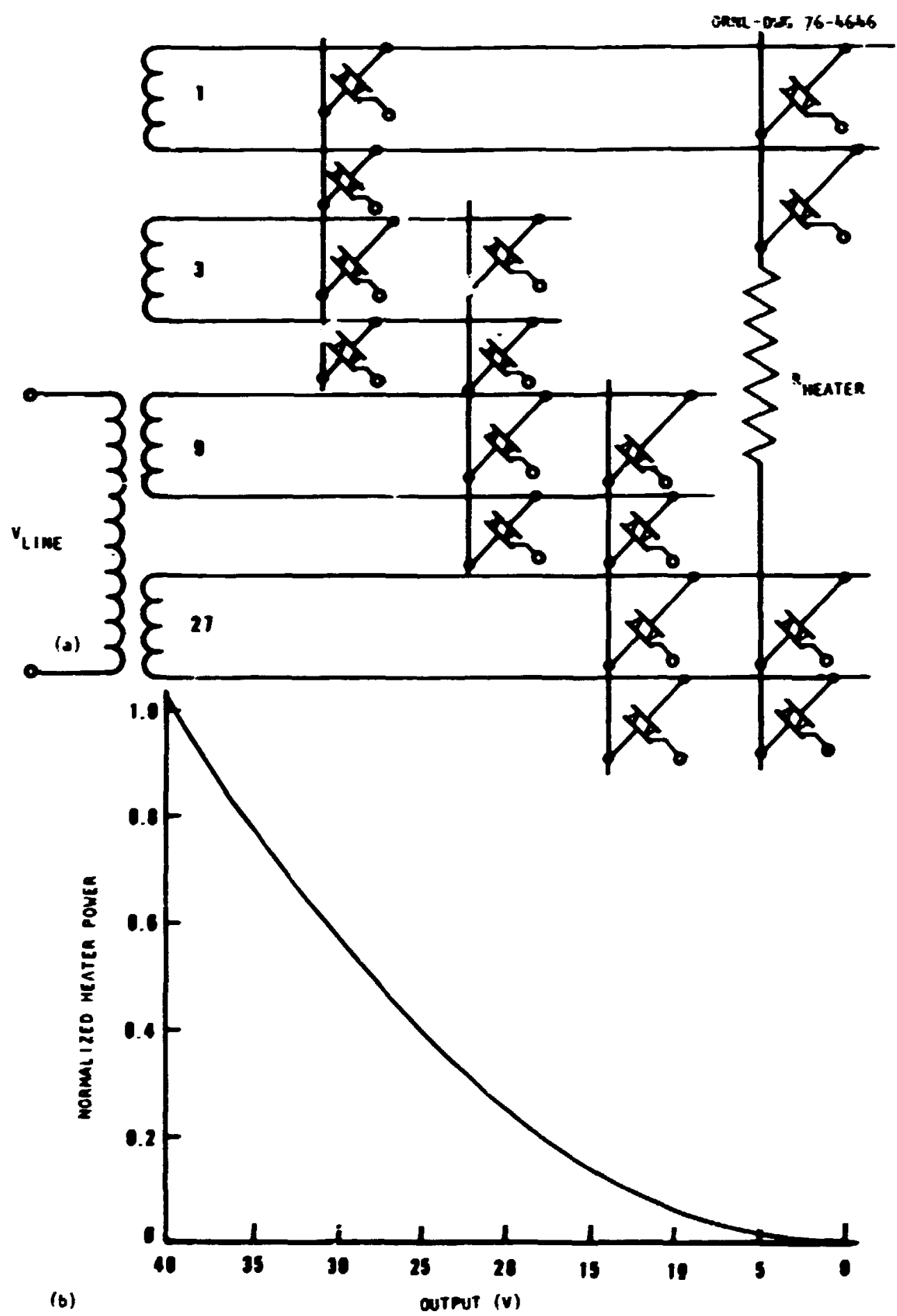

Fig. 3.37. Sultched-Transforer-Secondary Power Supply. (a) Wiring diagran. (b) Heatsr power versus voltage output. 


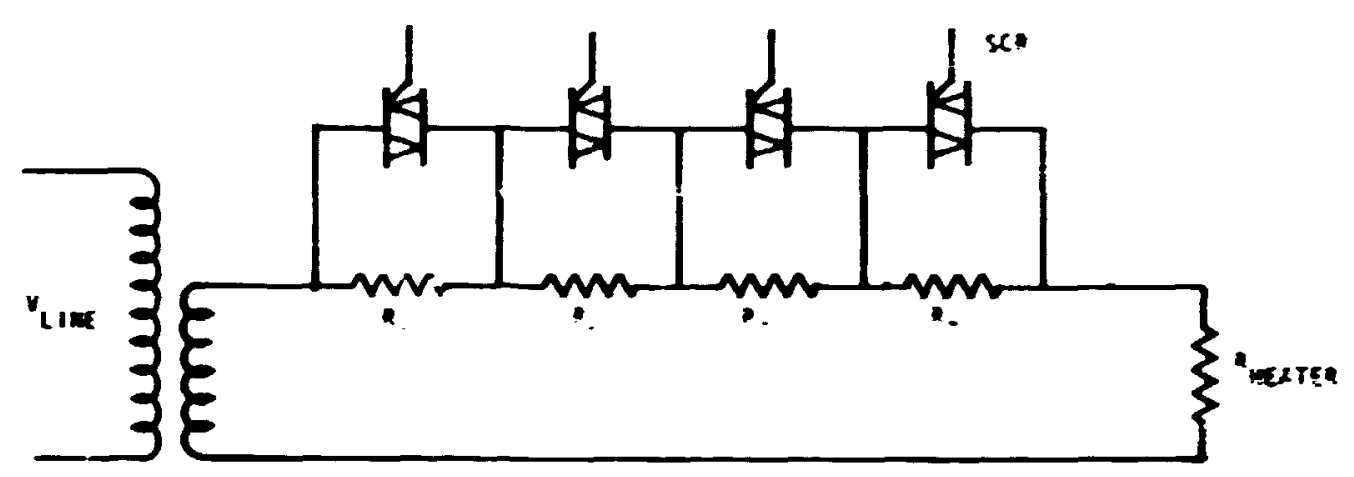

(s)

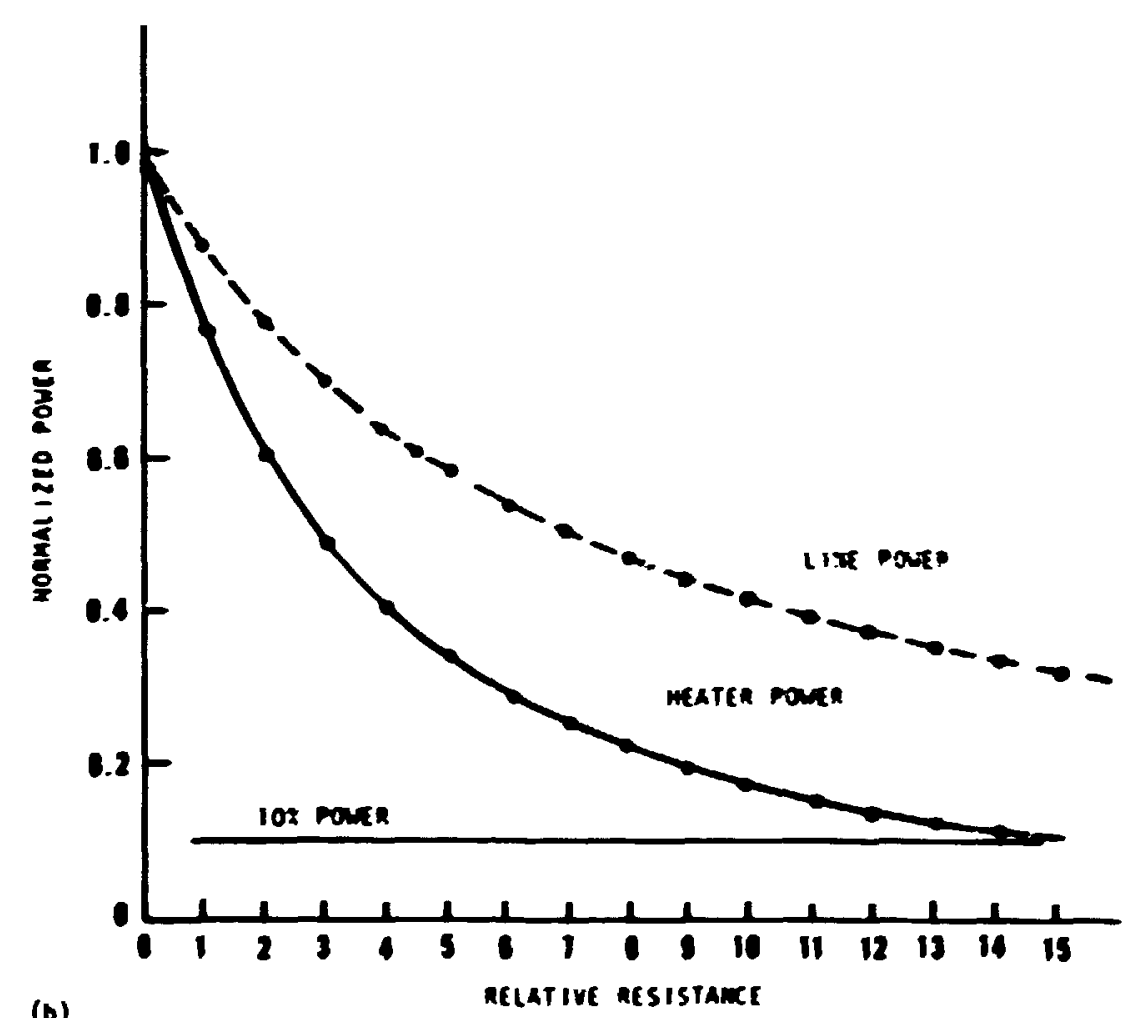

(b)

F18. 3.38. Suttched-Resistance Power Supply. (a) Wiring diagran.

(b) Beacer power and line power versus artch conbination. 


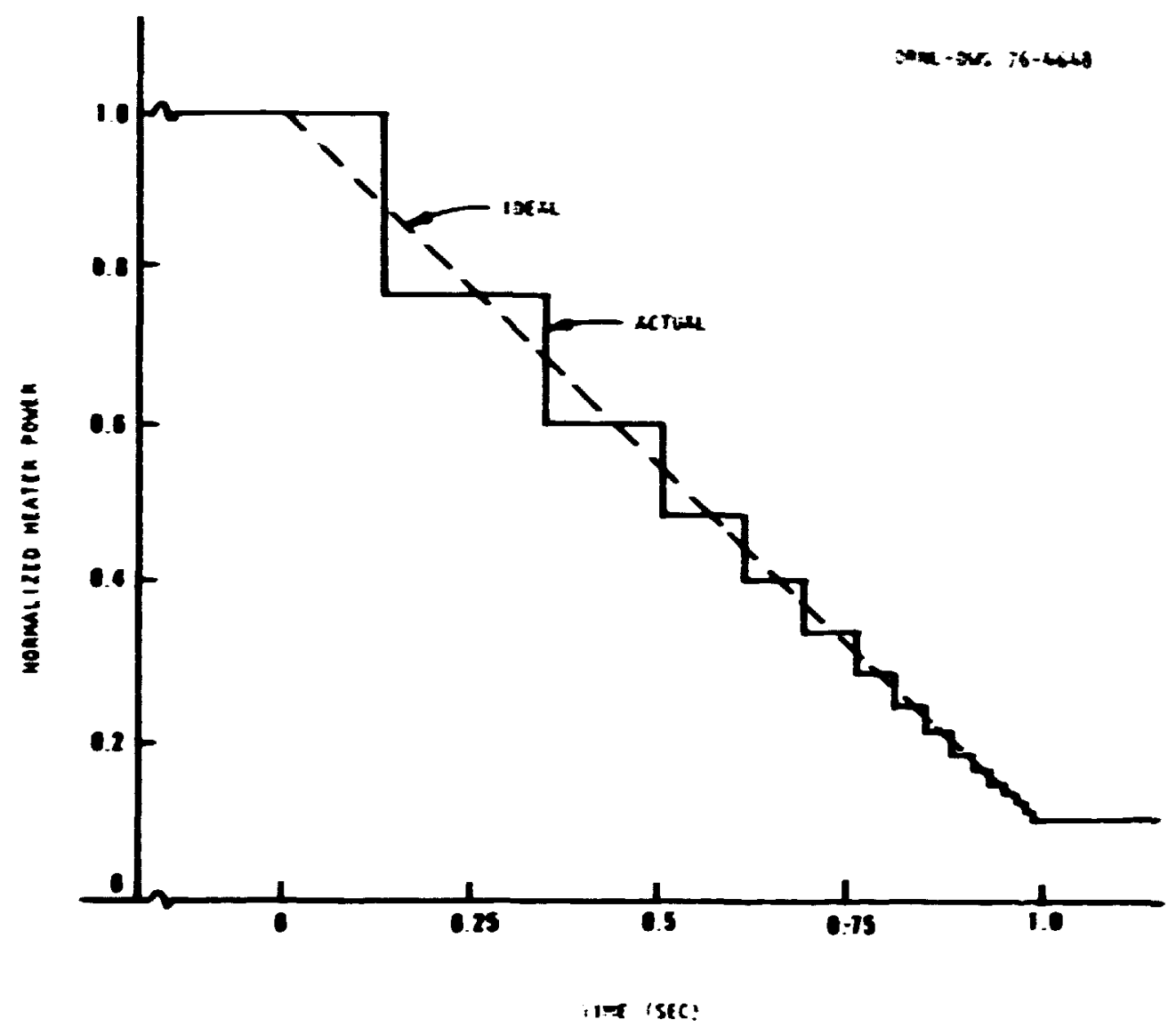

Fif 3.39. Optime Sultched Resister Systea Performence.

The sultched capacitor supply is show in Fig. 3.40(a). The secondary of the transforner must produce 402 greater voltage. For mxim power all the capacitors are consected in parallel. This capacitance, 15C, has a voltage drop equal to the heater voltage drop. The phase angle is 452 leading. As capactiors are taken out of the circuit, the pourer falls. Figure 3.60(b) shows this relationship. The maximan power step is 8.7\%. When this systen was cested in the lsboratory, ining probles were encoustered.

The aritched secondary system has the most advantages because no power is wasted, the kVA rating of the transformer dnes not have to be increased, and there are no tining probless.

\subsection{REFERESE}

1. J. L. Hurton, "Therwocouple Insulation Resistance," Instrumentation and Controls Div. Anru. Progr. Rep. Sept. 1, 1972, ONJL-4882, p. 66. 

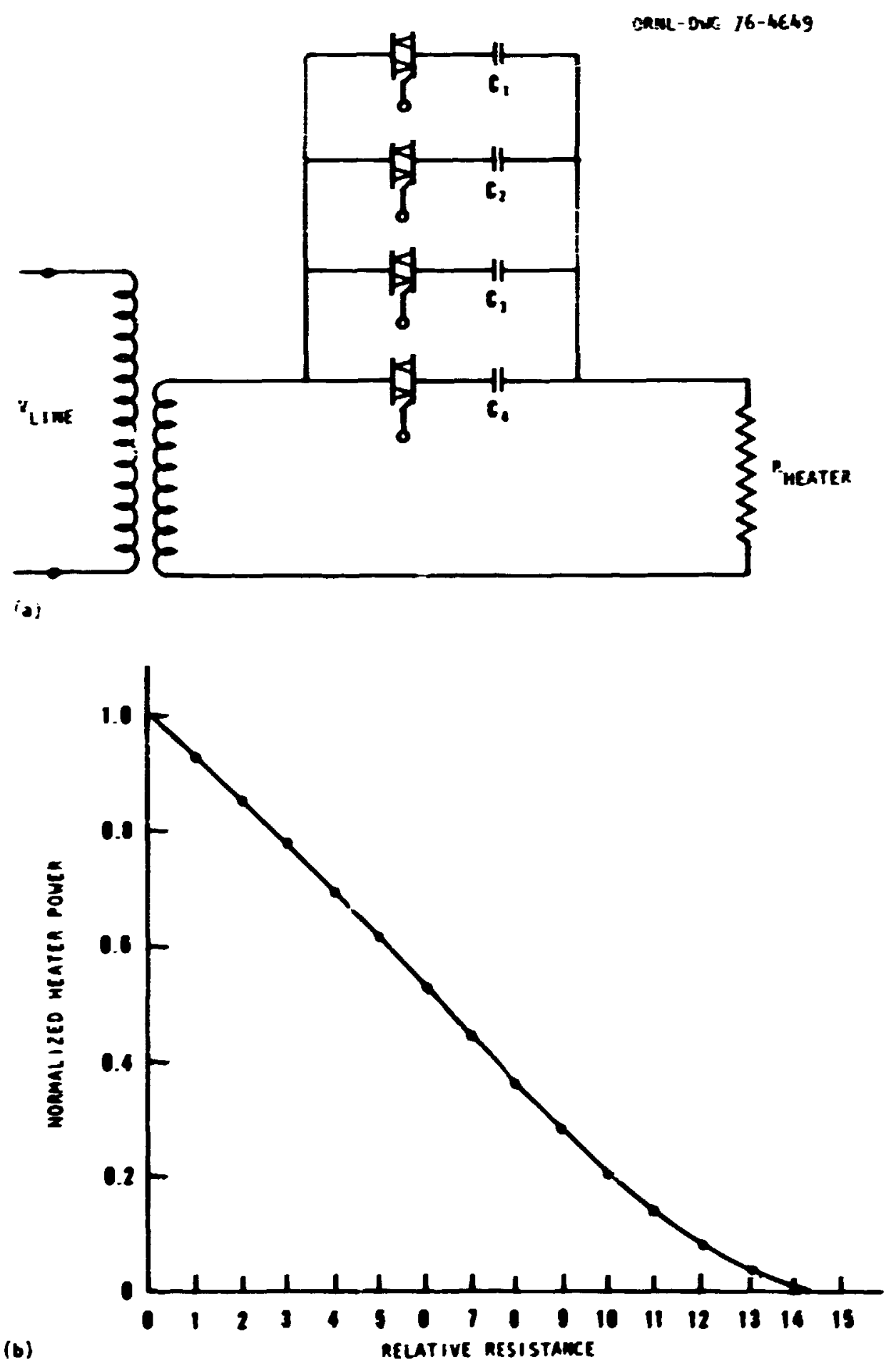

(b)

P18. 3.40. Sultched Capartitor Power Supply. (a) Wiring diagran. (b) Heater pover versus sitch cobinations. 



\section{GCFR SHIELDINS STUDIES}

\section{E. Bartine}

4.1 CaLCULATtuNS OF THE PRELIMINARY RADIAL SHIELD DESIGN - D. E. Battine In this first separate GCFR progress report, work is covered frow May 1974 through June 1975. Major areas are presented in chronological olver where possible, although funding fluctuations resulted in an oifagain-on-again approach to some items. Shielding studies at ORNL are closely coordinated with design work ${ }^{1}$ at $\mathrm{GA}$, and progress in this area is therefore the result of efforts of both institutions. Accomplishments to date include the identification or areas ior concern in the GCFK shielding model supplied by $\mathrm{C}_{A}$ and their incorporation into the GCFR shielding program plan, the development of cross-section sets, and their spplication in parametric studies to determine desirable computational models for GCFR calculations. These cross sections and modeling approaches were then applied in a cross-section sensitivity study for high-energy flux transmission to the PCRV liner, and to evaluate the effects of proposed revisions to the outer radial shield. Current results indicate that the prospects for reduction of the outer radial shield, and therefore the reactor cavity radius, are reasonably favorable frod the shielding point of view.

\subsubsection{Assessment of Basic Areas of Concern in the Development of a Shielding Program for a GCFR Conceptual Design}

The General Atomic Company provided the two-dimensional cylindrical model used for shielding calculations, which is show in Fig. 4.1. The core is divifed into four zones surrounded by :he depleted $\mathrm{VO}_{2}$ axial and $\mathrm{ThO}_{2}$ radial blankets. The core is suspended from the grid plate. Shielding is contained in the shaded zones, specifically the inner and outer radial shields, upper axial shields, and the lower axial shield. Special shielding protects the grid piate; concrece containment extends radially beyonc the iron liner in the form of the prestressed concrete reactor vessel (PCKV).

Transport calculations for the GA two-dimensional siciding model were run with DOT ${ }^{2}$ in $r-z$ geometry using the 50-group cross-section 


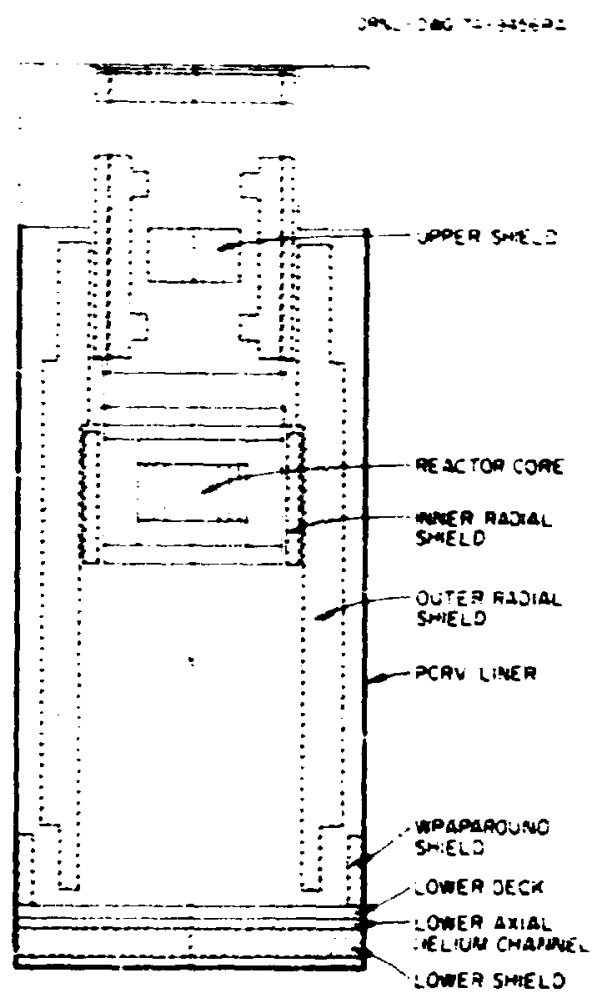

Fig. 4.1. Shielding Model of a 300-MN(e) GCFBR in Cylindrical Geometry.

11brary employed at ORNL for FFTP studies. Initial calculations were run $P_{1}$ and $S_{6}$, and an additional $P_{1}$ calculation of the lower outer radial shfeld "wraparound" region was run wth a biased quadrature set containing 306 angles designed to transport the flux bclow the outer shield and bask up to the PCRV liner. Isoflux levels were plotted for energy ranges above $1 \mathrm{keV}$, above $0.1 \mathrm{keV}$, and below $2.38 \mathrm{eV}$ (thermal) and for the total flux. Isodose and isodamage plots were also obtained, and flux spectra were plotted at several positions of interest. Figure 4.2 shows a total flux 180plot for the $r-z$ shielding model presented in Fig. 4.1, indicating flux levels starting with an inner level of $7 \times 10^{14} \mathrm{n} \mathrm{cm}^{-2} \mathrm{sec}^{-1}$ in decreasing factors of 10 . Inttial criteria for allowable flux levels vere a high-energy ( $>1 \mathrm{MeV}$ ) flux level of $2.7 \times 10^{9}$ and a low-energy $(<2.38)$ flux level of $1.0 \times 10^{9} \mathrm{n} \mathrm{cm}^{-2} \mathrm{sec}^{-1}$ at the PCRV iron liner and a fast (>0.1 MeV) flux level of $1.0 \times 10^{14} \mathrm{n}$ $\mathrm{cul}^{-2} \mathrm{sec}^{-1}$ at the face of the grid plate. It should be noted that these 


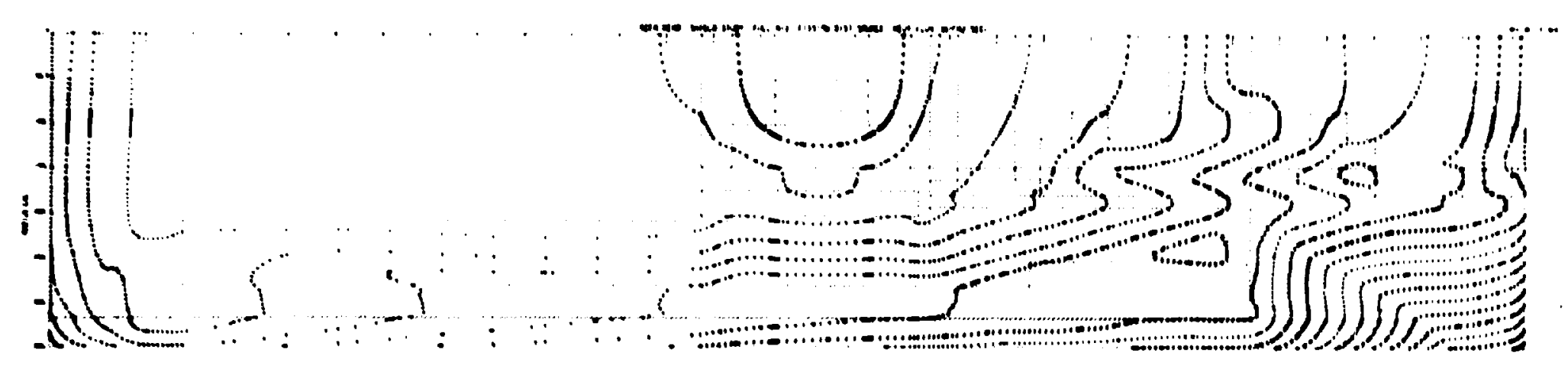

F18. 4.2. Isoplot of the Total Neutron Flux for the P-8 300 MW(e) GCPBR Sh1elding Model. Isoflux ines are shown for the inner level of $7 \times 10^{14} \mathrm{n}^{-2}$ sec $^{-1}$ in decreasing factors of 10 . 
constraints were adapted from the HTGR program and that constraints specifically applicable to the GCFR are gradually evolving. The constraint levels stated in this report are those that have been used at ORNL during FY 1975, and should be vieved as current indications of desired levels rather than as fixed maximum radiation levels.

Because sose discussion centered around the use of fluences to calculate radiation-induced damage in various stainless steel components and in the PCRV liner for the GCFR, 10z residual unifore elongation lifetimes in type 316 stainiess steel were calculated for the original GCFR shielding wodel provided by GA. The resulting lifetine contours are much wore constant over the region containing the axial and radial blankes, Inner shields, and grid plate than are the isodosc and isoflux curves. This is apparently due to danage build-up from the spectral softening in the blanket and shield zones. A 107 risidual elongation lifetime of $4 \times 10^{\circ} \mathrm{sec}$ was calculated for type 316 stainless steel at the face of the grid plate as colpared with a lifetine of $9.5 \times 10^{\circ} \mathrm{sec}$ for a fast ( $>0.1 \mathrm{MeV})$ fluence linit of $9.5 \times 10^{21} \mathrm{n} / \mathrm{cm}^{2}$.

The basic areas of concern identifiad in this preliminary study include transport to the PCRV liner through the thoriun oxide radial blasiet and radial shield and below the outer radial shield and streaming through the outlet coolant duct. The calculated high-energy flux levels at the grid plate face were arginally acceptable. However, since these calculations used a homgeneous representation of the core and blanket instead of the designed fuel rods and fuel rod cell assemblies, and since the type 316 stainless steel damage indicated halving the grid plate lifetime, streaming from the core to the grid plate face was also identified as an area of concern. This study was reported as part cf a joint ORN-GA presentation. ${ }^{3}$

\subsubsection{Production of a 51-25 Coupled Neutron-Gapa Cross-Section Library}

An effort was initiated to create a full set of cross sections for GCFR applications from the best ENDF data available. The 51-25 coupled neutron-gama energy group structure used for FTR and LMFBR Demonstration Reactor calculations was selected so that cross-section sets developed for those programs could be applied to the GCFR. The cross-section sets 
generated include helium, thoriun, and the ccistituent elements for concrete. All cross sections were originally generated in the 231-25 coupled neutron-gama energy group structure and thes collapsed to the 51-25 group structure. Below $15 \mathrm{KeV}$, the 231 neutron group structure is equivalent to the 239 group structure adopted as a standard by Cross-Section Evaluations Working Group (CSEUG). The heliun cross sections were generated with a $1 / E$ weighting function used for both the 231-25 and 51-25 sets. The concrete constituent elements cross sections were generated in the 231-25 group structure by use of $1 / E$ or $1 /\left(E \sigma_{T}\right)$ weighting functions and collapsed to 51-25 structure.

Weighting spectra for collapsing 231-25 cross-section sets for conc.ete constituents into the 51-25 group structure were created by the XSDRN code" from the flux energy distributions through the PCRV at the axial core ridplane and below the revised lorer axial shield. Additional weighting spectra were created to determine the effects of high iron content (rebar) concrete, the effect of weighting with the spectra at 0.3 m (l ft) fr the PCRV liner, which is approximately the position of the closest tendon, and the effect of using a relatively high $\mathrm{CaCO}_{3}$ mix similar to the concrete employed for TSF experiments. After examination of the collapsing spectra, concrete cross sections were obtained in the 51-25 group structure for the 0.3-m (1-ft) PCRV weighting function, the rebar concrete spertrum [similar to a 2.7-m (9-ft) PCRV spectrum], and the TSF concrete spectrum. Three 231-25 cross-section sets were prepared for thorium. Two sets were prepared with $1 / E$-toMaxwellian weighing but with different resonance treatments in the unresolved region: the first was treated as infinitely dilute, the second was given a Bondarenko-type treatment ${ }^{5}$ with $\sigma_{0}=22$. The third thorium set began with a Bondarenko treatment of the unresolved region and added a GAROLtype $^{6}$ resonance overlap (pointwise energy wesh weighting) and an eightzone $\mathrm{ThO}_{2}$ blanket rod spatial self-shielding model treatment for the resolved resonance region ( 4500 to $0.1 \mathrm{eV}$ ) using the ROLAIDS code. ${ }^{7}$ A fourth 231-25 thoriun cross-section set was generated with the ROLAIDS code for a two-zone spatial self-shielding model. Comparison of the efght-zone ROLAIDS-produced cross sections with the Bondarenko and 
Infinite dilution sets Indicated sizable differences near significant resonance structure. Hovever, little difference was noted between the eight-zone and two-zone ROLAIDS odels. The 1/E and Bondarenko 231-25 sets were collapsed to the 51-25 structure by use of the radial blanket spectrun generated in the 50-group calculations, and the BOLAIDS twozone set was collapsed to 51-25 by use of the point-energy spectrun generated by XIACS ${ }^{7}$ during the formation of the 231-group set.

AIthough no gana production data are avallable for thoriun in the ENDF/B files, two sets of ${ }^{232} \mathrm{Th}$ gam production cross sections were obtained in the 51-25 format. Inelastic gam production was obtained for both sets by adapting the ${ }^{23} \mathrm{U}$ inelastic gama production distribution and norallzing it by direct proportion to the ${ }^{232} \mathbf{T h}^{230} \mathrm{U}$ Inelastic cross-section ratios as a function of incident neutron energy group. Capture gama production was adopted from a Nuclear Data report ${ }^{\circ}$ for one cross-section set and fron a GA report by Engholn' for the other set. The methods used to obtain these two gama-production crosssectin sets are obviously stop-gap, and a real need exists to obtain good measurements of ${ }^{232} \mathrm{Th}$ gama-production cross sections and complete ENDF/B data files. Although thoriu game production does not appear to be a deternining consideration for radial shield design, it will be crucial for future investigations of heating in the radial blanket and at the core-blanket interface.

\subsubsection{Shleldigg Developent Progran Plan}

The ORIL contribution to the GCFR progran plan included the assessment of areas of concern discussed in Sect. 4.1.1, the development of long-term schedule and cost estimates to satisfy these corcerns, and an analysis of the Impact of LMPBR-generated shielding wethods, calculations, and experiments on the GCPR shielding progran. The full progran plan $^{6}$ was written and asserbled at $\mathrm{GA}^{10}$ and, after the nomal series of reviews and iterations, basically agreed to at a meting in May. Th.e development of the shielding progran plan stands as one of the mas accomplishsents of FY 1975, and forml adoption is expected early in FY 1976. 


\subsubsection{Study of the Sensitivity of the Flux ( $>1 \mathrm{MeV})$ at the} PCRV Liner to Cross Sections in the One-Dinenstonal Radial Traverse (Core Midplane) Mode!

This particular sensitivity study (high-energy flux at the PCRV liner for the reference radial shield) is indicative of some of the informatin that ay be obtained fron this type of study. The sensitivity stud: was performed with the one-D discrete ordinates code ANISN ${ }^{11}$ and the sensitivity analysis code swarlare. ${ }^{12}$ The sensitivity by zone is presented in Table 4.1 and shows that the high-energy flux at the

Table 4.1. Cross-Section Sensitivities of High-Energy (>1 MeV) Flux at PCRV Liner

\begin{tabular}{|c|c|c|c|c|}
\hline \multirow{2}{*}{ Zone } & \multirow{2}{*}{$\begin{array}{l}\text { Signif ficant } \\
\text { Type of } \\
\text { Material }\end{array}$} & \multicolumn{2}{|c|}{ Sensitivity } & \multirow{2}{*}{$\begin{array}{c}P_{1} \\
\text { Sensitivity }\end{array}$} \\
\hline & & zone & Material Total & \\
\hline 1 & Core & -0.0225 & & \\
\hline 2 & Core & $\neg .0680$ & & \\
\hline 3 & Core & -0.261 & & \\
\hline 4 & Core & -0.715 & -1.05 & +1.5 \\
\hline$s$ & $\begin{array}{l}\text { Radial } \\
\text { bl anket }\end{array}$ & -4.25 & -4.24 & -31.0 \\
\hline 6 & Coolant & -0.0470 & & \\
\hline 7 & Graphite & -1.53 & & \\
\hline 8 & 304 SS & -2.34 & & \\
\hline 9 & Cool ant & -0.0163 & & \\
\hline 10 & 304 SS & -1.72 & & \\
\hline 11 & Graphite & -2.14 & & \\
\hline 12 & 304 SS & -1.97 & & \\
\hline 13 & Graphite & -1.62 & -5.29 & \\
\hline 14 & 304 SS & -2.49 & -0.52 & -47.1 \\
\hline 15 & Coolant & -0.198 & -0.26 & +0.5 \\
\hline 16 & Liner & -0.0147 & +0.01 & $\$ 2.35$ \\
\hline 17 & PCRV & +0.0020 & 0.00 & -0.31 \\
\hline \multicolumn{2}{|c|}{ SYSTEM TOTAL } & & -19.4 & -84.5 \\
\hline
\end{tabular}

Q Mubbers are percent changes in response $(\phi(E>1$ MeV) at the PCRV linerl per percent increase in cross section, as predicted by 1 inear perturbat ion theory.

bubers are percent change in response $l \phi(E>1 \mathrm{MV})$ ot the PCRV 1 iner $]$ due to changing from $P_{3}$ to $P_{1}$ Legendre expansion of the flux, as predicted by 1 inear perturbation theory. 
liner is very sensitive to cross sections used in the radial odel. The total sensitivity of -19.4 indicates that increasing all cross sections in the systen by 17 would decrease the high-energy flux at the liner by 19.47, according to lisear perturbation theory. The highest mgnitude of sensitivity for any zone is that for the radial blanket, zone 5, of -4.25 . The type 304 stainless steel and graphite zones of the heterogeneous radial shield representation are also significant. The $P_{3}-t o-F_{1}$ predictions are given as the total predicted effect of the nixture over the system, and again Indicate the importance of the radial blanket. The $P_{i}$ predictions also give some indication of the degree of linearity of the systen, since the total predicted ef fect of $-84.5 \%$ ay be comared with the calculated vaiue of 44.27 . This difference is typical of linear restrictions, since predicted change of 847 is beyond the linear range. A direct study of the effects of the various radial zones is presented in Table 4.2, where the largest reduction in the high-energy flux due to nuclear interaction clearly occurs in the

Table 4.2. Reduction in Fux (>1 MeV) for the CCFR Reference Radial shield

\begin{tabular}{|c|c|c|c|}
\hline \multirow[b]{2}{*}{2000} & $\theta(E>1 \mathrm{~mm}) \mathrm{cos} 1 \mathrm{~s}$ & Ixco $20 \mathrm{me} / \mathrm{e}(\mathrm{E}>1 \mathrm{nov})$ & \multirow{2}{*}{$\frac{\text { D) Lexing } 2000}{\text { Tocel }}$} \\
\hline & $\begin{array}{l}\text { moclear } \\
\text { lnterect }\end{array}$ & conperie & \\
\hline Rodisl blamet & so. 3 & 2.2 & 120.9 \\
\hline Coolene & 1.0 & 1.6 & 1.4 \\
\hline 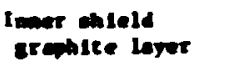 & 3.6 & 1.2 & 4.0 \\
\hline 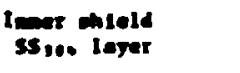 & 3.6 & 1.2 & 6.5 \\
\hline coolent & 1.1 & 1.1 & 1.2 \\
\hline 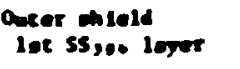 & 3.3 & 1.1 & 3.9 \\
\hline $\begin{array}{l}\text { Oxeer mield } \\
\text { lot erephite } \\
\text { loyer }\end{array}$ & 10.2 & 1.2 & 11.9 \\
\hline $\begin{array}{l}\text { Oncer inield } \\
20 \mathrm{ds} \text { yoe layer }\end{array}$ & 3.7 & 1.1 & 6.3 \\
\hline $\begin{array}{l}\text { Outer inleld } \\
2 \text { grepenite } \\
\text { loger }\end{array}$ & 5.2 & 1.1 & 5.7 \\
\hline 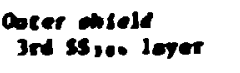 & 11.6 & 1.1 & 13.2 \\
\hline Oue let cooleat & 1.5 & 1.1 & 2.0 \\
\hline 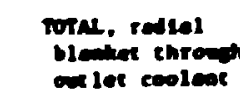 & $2.3 \cdot 10^{7}$ & 10 & $2.3=10^{\circ}$ \\
\hline
\end{tabular}


radial blanket, again confiraing the sensitivity results. High reductions are also noted for the first graphite layer and the last type $30 ;$ stainless steel layer of the outer shield. Cross-section sensitivities by element and zone are presented in Tables 4.3 and 4.4, Indicating especially high sensitivity to thoriun and fron cross sections. In using the sensitivity analysis technique for more advanced design problews. the sensitivities for partial cross sections (such as inelastic and capture) would be deternined and then folded with estinates of the uncertainties in these cross sections to $g$ ive an estimated uncertainty in the result [here, the flux ( $>1 \mathrm{MV})$ at the PCRV liner] due to crosssection uncertainties.

Table 4.3. Sensitivity of High-Energy ( $>1 \mathrm{MeV}$ ) Flux at PCRV Iron Iiner to Elements of Stainless Steel in Core, Blanket, and Shield

\begin{tabular}{|c|c|c|c|c|c|}
\hline \multirow{2}{*}{ Zone } & \multicolumn{4}{|c|}{ Sensitivity for Each Element } & \multirow{2}{*}{$\begin{array}{l}\text { Senolt ivity } \\
\text { for Type } \\
304 \text { SS }\end{array}$} \\
\hline & Iron & xickel & Chroniua & Molybdenum & \\
\hline 1 core & $-6.3 \times 10^{-3}$ & $-1.3 \times 10^{-3}$ & $-1.5 \times 10^{-1}$ & $-2.8 \times 10^{-6}$ & \\
\hline 2 Core & $-1.91 \times 10^{-1}$ & $-3.9 \times 10^{-3}$ & $-4.5 \times 10^{-3}$ & $-8.6 \cdot 10^{-6}$ & \\
\hline 3 Core & -0.0676 & -0.0139 & -0.0163 & $-3.0 \times 10^{-3}$ & \\
\hline 4 Core & -0.194 & -0.0395 & -0.0692 & $-8.6 \times 10^{-3}$ & \\
\hline S Blanker & -0.873 & -0.172 & -0.219 & -0.0375 & \\
\hline 8 Shield & -1.66 & -0.22 & -0.48 & & -2.36 \\
\hline 10 Shield & -1.21 & -0.16 & -0.35 & & -1.72 \\
\hline 12 Shield & -1.37 & -0.19 & -0.41 & & -1.97 \\
\hline 14 Shield & -1.74 & -0.23 & -0.52 & & -2.49 \\
\hline Core TOTAL & -0.26 & -0.06 & -9.07 & -0.05 & \\
\hline Blanker TOTAL & -0.87 & -0.17 & -0.22 & & \\
\hline Shield Total & -5.96 & -0.80 & -1.76 & & $\rightarrow .52$ \\
\hline \multicolumn{6}{|l|}{$\vec{f}$ Sensitivity } \\
\hline Core & +0.6 & +0.1 & 0.0 &.- .2 & \\
\hline Bl anket & -7.0 & -1.9 & -0.2 & & \\
\hline Shield & -32.3 & -4.6 & -10.2 & & -47.1 \\
\hline
\end{tabular}

The results of this sensitivity analysis indicate the ifportance of calculating through $\mathrm{ThO}_{2}$ and type 304 stainless steel and, since 1 ron cross sections have been fairly well investigated, especially indicate the Importance of "good" (1ow-uncertainty) cross suctions for thoriun, and also for chroniun and nickel. 
Table 4.4. Sensitivity of Eigh-Energy (>1 MeV) Flux at PCRV Iron Liner to Elenents of Thoriun Oxide in Radial Blanket

(Zone 5)

\begin{tabular}{lcc}
\hline \multirow{2}{*}{ Element } & \multicolumn{2}{c}{ Sensitivity } \\
\cline { 2 - 3 } & Cross Section & $E_{1}$ \\
\hline${ }^{232} \mathrm{Th}$ & -2.03 & -17.1 \\
0 & -0.88 & -3.2 \\
$\mathrm{ThO}_{2}$ & -2.91 & -20.3 \\
\hline
\end{tabular}

4.1.5 Study of Cross-Section, Calculational Paraneter, and Hodeling Effects on Calculated Results for the Initial Radial Shield Configuration

A detailed evaluation of the effects of cross sections and calculational parameters on calculations of the one-dimensional radial reference design neutron flux was completed, including comparative oneand two-dimensional results. The results are sumarized in Table 3.5, where the flux levels given are per source neutron. To note some of the more significant comarisons, the 2-D calculated flux levels are a factor of 2 higher at the PCRV liner for both high- and low-energy neutrons. The new 51-group cross sections increased the high-energy flux slightly ( 20z) but halved the thermal flux at the liner. However, the thernal flux transaitced through the radial blanket was increased by $\mathbf{4 0 z}$ by the ROLAIDS resolved resonance treatment for the thorius cross section (the so-group sets were infinitely dilute $1 / E$ weighted). colng from $P_{1}$ to $P_{3}$ Legendre expanstons of the angular dependence of the flux doubled the high-energy flux at the liner. In the final row, the Inner and outer radial shlelds were represented by separate graphite and type 304 stainless steel layers instead of by a homgeneous 50-50 graphite and type 304 stainless steel axture. The heterogeneous shield representation resulted in a $30 \%$ increase in the high-energy flux transatted to the liner, whlle the thermal flux was increased in the outer portion of the radial blanket by approximtely a factor of 5 because of reflection fron the graphite first layer of the Inner shield, but it 1s $60 \%$ lower at the liner. 
Table 4.5. GCFR Fast and Thermal Flux Calculation Comparieons for the Reference Radial Shield Design at Core Midplane

\begin{tabular}{|c|c|c|c|c|}
\hline \multirow{3}{*}{ Calculation } & \multicolumn{4}{|c|}{ Normalized Flux at Var lous Losationa } \\
\hline & \multicolumn{3}{|c|}{ Outer Boundary of } & \multirow{2}{*}{$\begin{array}{l}\text { PCRV } \\
\text { Liner }\end{array}$} \\
\hline & Core & Radial Blanket & Inner Shield & \\
\hline \multicolumn{5}{|c|}{ Fant Flux $(>1 \mathrm{MeV})$} \\
\hline $\begin{array}{c}\text { DOT 2-dilmonelon } \\
P_{1} \text { so group } \\
\text { homozeneous }\end{array}$ & $1.7 \times 10^{-5}$ & $1.2 \times 10^{-1}$ & $2.3 \times 10^{-1}$ & $1.3 \times 10^{-10}$ \\
\hline $\begin{array}{l}\text { ANISN } 1 \text {-dinension } \\
P_{1} \text { so sroup } \\
\text { homoseneous }\end{array}$ & $4.7 \times 10^{-1}$ & $2.8 \times 10^{-1}$ & $4.8 \times 10^{-10}$ & $3.1 \times 10^{-13}$ \\
\hline $\begin{array}{l}P_{1} \$ 1 \text { sroup } \\
\text { homogeneous }\end{array}$ & $3.9 \times 10^{-6}$ & $2.9 \times 10^{-1}$ & $3.2 \times 10^{-10}$ & $6.4 \times 10^{-13}$ \\
\hline $\begin{array}{l}\text { P, S1 group } \\
\text { homosencous }\end{array}$ & $3.9 \times 10^{-6}$ & $3.0 \times 10^{-1}$ & $6.3 \times 10^{-10}$ & $1.3 \times 10^{-16}$ \\
\hline $\begin{array}{l}\text { P, } 51 \text { sroup } \\
\text { hoterogeneous }\end{array}$ & $3.9 \times 10^{-6}$ & $3.0 \times 10^{-1}$ & $8.7 \times 10^{-10}$ & $1.7 \times 10^{-16}$ \\
\hline \multicolumn{5}{|c|}{ Thereal Flux $(<2.38 \mathrm{eV})$} \\
\hline $\begin{array}{l}\text { DOT 2-dimenalion } \\
P_{1} \text { so group } \\
\text { homeonencous }\end{array}$ & $1.8 \times 10^{-10}$ & $1.6 \times 10^{-6}$ & $2.6 \times 10^{-1}$ & $6.3 \times 10^{-12}$ \\
\hline $\begin{array}{l}\text { NISN 1-dimenation } \\
P_{1} \text { so sroup } \\
\text { homoseneous }\end{array}$ & $3.2 \times 10^{-10}$ & $1.8 \times 10^{-1}$ & $2.3 \times 10^{-0}$ & $3.4 \times 10^{-12}$ \\
\hline 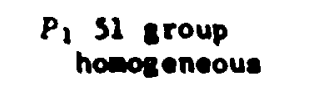 & $1.2 \times 10^{-10}$ & $2.5 \times 10^{-1}$ & $2.1 \times 10^{-1}$ & $1.8 \times 10^{-12}$ \\
\hline 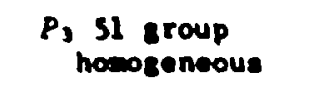 & $1.2 \times 10^{-10}$ & $2.5 \times 10^{-1}$ & $2.1 \times 10^{-1}$ & $2.1 \times 10^{-12}$ \\
\hline $\begin{array}{l}P_{3} 31 \text { group } \\
\text { heterogenoous }\end{array}$ & $1.7 \times 10^{-10}$ & $1.3 \times 10^{-1}$ & $6.1 \times 10^{-9}$ & $1.3 \times 10^{-12}$ \\
\hline
\end{tabular}


Calculattooal results for weutron and gama-ray heating are compared sintlarly in Table 4.6. The units used correspond to those given for allowable heating rates.' The heating at the first tendon position in the PCIV is gaven in rads absorbed in tissue and rads absorbed in concrete since a set of kerm factors for the tendon lubricant was not yet available. For all cases, the neutron heating is not significant compared with the gam heating at the same position. Increasing the Legendre expansion from $P_{1}$ to $P_{3}$ increased the heating by up to $50 z$, but using a heterogeneous radial shield representation reduced the heat ing to levels sindar to or lover than those calculated in the $P_{1}$ homgeneous case. The tendency of heterogeneous radial shield representation to lower the game heating is consistent with the previously noted increase in the high-energy flux at the liner, thereby decreasing the low-energy flux transitted through the shield and the nuber of garma rays produced by capture of low-energy neutrons in iron.

Table 4.6. GCFR Heating Calculational Comparisons for the Reference Radial Shield Design

\begin{tabular}{|c|c|c|c|}
\hline \multirow[b]{2}{*}{ Position } & \multicolumn{3}{|c|}{ Value by Each Calculation } \\
\hline & $\begin{array}{l}P_{1} \quad 51-25 \\
\text { Homogeneous }\end{array}$ & $\begin{array}{l}P_{3} 51-25 \\
\text { Homogeneous }\end{array}$ & $\begin{array}{c}P_{3} 51-25 \\
\text { Heterogeneous }\end{array}$ \\
\hline \multicolumn{4}{|c|}{ Neutron Heat Ing } \\
\hline $\begin{array}{l}\text { PCRV Inside liner, } \\
W / a^{3}\end{array}$ & $6.1 \times 10^{-22}$ & $8.8 \times 10^{-22}$ & $1.9 \times 10^{-21}$ \\
\hline $\begin{array}{l}\text { PCRV at first tendon, } \\
\text { rads-concrete }\end{array}$ & $8.2 \times 10^{-25}$ & $1.2 \times 10^{-24}$ & $1.5 \times 10^{-24}$ \\
\hline \multicolumn{4}{|c|}{ Gana Heating } \\
\hline $\begin{array}{l}\text { PCRV ingide liner, } \\
\mathrm{H} / \mathrm{m}^{3}\end{array}$ & $8.7 \times 10^{-20}$ & $1.1 \times 10^{-19}$ & $6.7 \times 10^{-20}$ \\
\hline $\begin{array}{l}\text { PCRV a.t first tendon, } \\
\text { rads-concrete }\end{array}$ & $5.7 \times 10^{-22}$ & $8.2 \times 10^{-22}$ & $5.9 \times 10^{-22}$ \\
\hline rads-tissue & $6.4 \times 10^{-22}$ & $9.7 \times 10^{-22}$ & $6.7 \times 10^{-22}$ \\
\hline
\end{tabular}


The calculated flux and heating levels are compared uith curreatly recomended matin levels in Table 4.7. The results show that, according to these 1-D calculations, the prelininary wodel of the CSFR radial shield meets all given constrafnts. The tendon lubricant heating should be reevaluated then kerna factors are avallable for the grease. The homgeneous radial shield calculations referted to are the results obtained from the high-angular-quadrature lower axial 2-D calculation mde with the original 50-group cross-section set. The heterogereous figures are the result of a series of 2-D calculations that were run on the heterogeneous reference wdel by use of a $P_{3}$ Legendre expansion of the 5i-25 cross-section set. A core $k_{\text {eff }}$ calculation, which includes the radial and axial blankets and adjacent upper and lower axial regions,

Table 4.7. A Comparison of Current ly Recomended Maximum Radiation Levels with One- and Tro-Dirensional Calculated Values for Preliminary Models of the GCFR Radial Shield Along the Core Midplane

\begin{tabular}{|c|c|c|c|}
\hline \multirow[b]{2}{*}{ Paraecter and Posiction } & \multirow{2}{*}{$\begin{array}{l}\text { Recomeaded } \\
\text { Constraint }\end{array}$} & \multicolumn{2}{|c|}{ Calculactonal Resulcs } \\
\hline & & $\begin{array}{l}2-0,51 \\
\text { so Group }\end{array}$ & $\begin{array}{l}1-D, F 3,31-25 \text { Group } \\
\text { Hererogeneous Radial Shield }\end{array}$ \\
\hline Flux (>! MeV) PCRV liner, n $\mathrm{cm}^{-2} \mathrm{sec}^{-i}$ & $2 \cdot 10^{9}$ & $9.2 \cdot 10^{5}$ & $1.2 \times 10^{6}$ \\
\hline Flux $(<2.38 \mathrm{eV})$ PCRV liter, $\mathrm{n} \mathrm{cm}^{-i} \mathrm{sec}^{-1}$ & $1 \cdot 10^{9}$ & $4.5=10^{\prime}$ & $9.2 \times 10^{7}$ \\
\hline Hear ing in PCPV, $\mathrm{H} / \mathrm{m}^{3}$ & 1000 & & 4.8 \\
\hline $\begin{array}{l}\text { Heating in cendon Iubricant } \\
\text { (rads in grease) }\end{array}$ & $0.1^{\mathrm{c}}$ & & $0.062^{d}$ \\
\hline 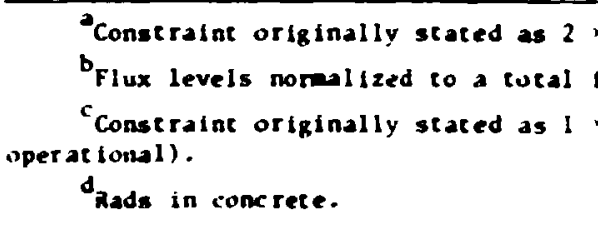 & $\begin{array}{l}10^{10} \mathrm{n} / \mathrm{cm}^{2} \\
1 \mathrm{ux} \text { of } 7.1 \\
10^{\circ} \text { rads ove }\end{array}$ & $\begin{array}{l}\text { plant lif } \\
\text { plant litec }\end{array}$ & $\begin{array}{l}\text { etiace. } \\
\text { ee } \\
\text { ine ( } 40 \text { yeats it } 807\end{array}$ \\
\hline
\end{tabular}

geve a $k_{\text {eff }}$ value of 1.07 , which is in reasonable agreement with the GA value of 1.06 . The second calculation included the full 2-D wodel up through the grid plate. The core calculation served as a surce for the second run, witch was calculated with an $S_{6}$ quadratuie ( 30 ar.gles). The angular flux was taken from tils 2-D calculation at vertical position just beiow the assembly bottow fitting, and then transssted 
below the outer shieli and up the outlet coolant duct by use of a blased 302 anzular quadraiure. Table 4.8 presents the res'ilts of this calculation at some positions of interest. The lower axial helfim channel is located below the lower stainless steei pre-shield. The wrap-around region is the vertical level under the outer shield where an additional shield section has been appendaged to the 1 iner. The streaning path designation refers to the position at which particles streaming under the uuter shield and up the outlet coolant channel meet che PCRV Iiner.

Table 4.8. Comparison of Currently Recomended Maximum Radiation Levels with Two-Dizensional Calculated Values for the Homogeneous and Heterogeneous Reference Mode's of the Lower Axtal Area of the GCFR Outer Radial Shield

\begin{tabular}{|c|c|c|c|c|c|}
\hline \multirow{2}{*}{ Location } & \multirow{2}{*}{$\begin{array}{l}\text { Shield } \\
\text { Model }\end{array}$} & \multicolumn{2}{|c|}{ Flux at PCRV Liner, $n \mathrm{cs}^{-2} \sec ^{-4}$} & \multirow{2}{*}{$\begin{array}{c}\text { Heac ins in } \\
\text { PCRV } \\
\text { (W/E) }\end{array}$} & \multirow{2}{*}{$\begin{array}{l}\text { Heat ing in Tendon } \\
\text { Lubrtcant ( } r \text { rads } \\
\text { in grease) }\end{array}$} \\
\hline & & $>1 \mathrm{MeV}$ & $<2.38 \mathrm{eV}$ & & \\
\hline $\begin{array}{l}\text { Recuenended } \\
\text { constratric }\end{array}$ & & $2 \times 10^{36}$ & $1 \times 10^{3}$ & 1000 & $0.1^{c}$ \\
\hline $\begin{array}{l}\text { Liwer axial } \\
\text { He channel }\end{array}$ & $\begin{array}{l}\text { Horogeneous } \\
\text { Heterogeneous }\end{array}$ & $\begin{array}{r}5 \times 10^{7} \\
2.4 \times 10^{7}\end{array}$ & $\begin{array}{l}3.3 \times 10^{50} \\
3.7 \times 10^{10}\end{array}$ & 700 & $5.5^{d}$ \\
\hline $\begin{array}{l}\text { Wrap-around } \\
\text { region }\end{array}$ & $\begin{array}{l}\text { Homogeneous } \\
\text { Heterogenecus }\end{array}$ & $\begin{array}{r}8 \times 10^{7} \\
7.1 \times 10^{7}\end{array}$ & $\begin{array}{l}6.1 \times 10^{10} \\
3.3 \times 10^{10}\end{array}$ & 1000 & 7.7 \\
\hline $\begin{array}{l}\text { Streaning } \\
\text { pach }\end{array}$ & $\begin{array}{l}\text { Howogeneous } \\
\text { Heterogeneous }\end{array}$ & $\begin{array}{r}6 \times 10^{7} \\
5.3 \times 10^{7}\end{array}$ & $\begin{array}{l}7.8: 10^{10} \\
7.8 \times 10^{10}\end{array}$ & 1800 & 12 \\
\hline
\end{tabular}

The high-eneıgy flux peaks in the wrap-around region for both calculations, but is still well below the established criteria. The thermal flux peaks at the streaming path position and does exceed the current critertion but could be reduced by boronating the graphite in the reference outer shield. The results indicate no significant difference for the peak values of the high-energy flux, but do show a factor of $2 \mathrm{~d}$ ffrerence in the thermal flux in the wrap-around region, presumably due to the heterogeniety effect noted In Table 4.5. Calculated gamma heating and dose rates in the PCRV 
are also given for the heterogeneous case. The heating in the PCRV peaks in the streaming path and is marginal, but should also be affected by brronation of the outer shield graphite. Danage to the teadon lubricant also peaks in the streaning path. As mentioned earlier, this response is not definitive, but does indicate an area for concern, although this response should also be reduced by boronation of outer shield graphite. While none of the parameters investigated peak in the regicn of the lcyer axial helium channel, this region is also of some concern. A revised shieid configuration could have the outer shield graphite boronated to witfgate the effects of reducing the outer shield and moving in the PCRV liner by $0.3 \mathrm{a}(\mathrm{ft})$. However, the effect of the boronation on the paraneters at the lower hellum gap is nut yet clear.

\subsubsection{Comparative Calculations of Reference and Revised Models for the Outer Radial Shield}

The general conclusion reached on the basis of the calculations described in Sect. 4.1.5 was that the reference radial shield design was basically conservative. The economic incentive to reduce the radius of the reactor cavity therefore led to an effort by GA to redesign the outer radial shield ${ }^{13}$ to reduce the radius of the reactor cavity by about $0.3 \mathrm{~m}(1 \mathrm{ft})$. This section compares calculated results for selected redesign options with calculations made with the reference shield corfiguration.

A series of calculations of flux and heating rates along the core midflane radial axis was completed, and the comparative results are presented in Table 4.9. All calculations used the 51-25 cross-section set with a $P_{3}$ legendre expansion and a heterogeneous represe:itation of the inner and outer radial shields. The normal reference shield configuration is the one that has been in use for previous calculations. The alternate reference shield configuration is a different $r-\theta$ path through the reference radial shield in which the interior stainless steel region of the outer radial shield is replaced by a graphite region. The revised shield configuration has the same inner shield as the reference model, but the outer shield thickness has been reduced by $0.3 \mathrm{~m}(1 \mathrm{ft})$, and the graphite region of the outer radial shield has been boronated. The 
Table 4.9. A Comparison of Recomended Maxime Radiation Levels with One- and Two-Dimensional Calculated Values for

Various Prelininary Models of the GCFR Radial

Shield Aloug the Core Midplane

\begin{tabular}{|c|c|c|c|c|c|}
\hline \multirow{2}{*}{ Calculation } & \multirow{2}{*}{$\begin{array}{l}\text { Shield } \\
\text { sodel }\end{array}$} & \multicolumn{2}{|c|}{ 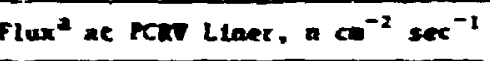 } & \multirow{2}{*}{$\begin{array}{l}\text { Heatiog is } \\
\text { PCAY } \\
\text { (W/E) }\end{array}$} & \multirow{2}{*}{$\begin{array}{l}\text { Heat in in Teudoo } \\
\text { Lubricant (rads } \\
\text { in grease) }\end{array}$} \\
\hline & & Pl theV & $<2.30 \times$ & & \\
\hline \multicolumn{2}{|c|}{ Reconsended constralat } & $2 \times 10^{96}$ & $1 \cdot 10^{\prime}$ & 1000 & $0.1^{c}$ \\
\hline 2-D & Nef erence & $5.6 \times 10^{5}$ & $3.0 \times 10^{\circ}$ & 7.2 & 0.10 \\
\hline$!-D$ & Weference & $1.2 \times 10^{6}$ & $9.2 \times 10^{\top}$ & 4.8 & 0.042 \\
\hline $1-D$ & Altermace lies. & $2.3 \times 10^{6}$ & $8.1 \times 10^{7}$ & 1460 & 0.25 \\
\hline$:-D$ & Revised & $7.8 \times 10^{T}$ & $1.1 \times 10^{\circ}$ & 150 & 1.6 \\
\hline$I-D$ & Revised, so B.C & $8.5 \times 10^{7}$ & $10^{6}$ & 330 & 2.8 \\
\hline
\end{tabular}

Tlux levals numalized to e total flux of $7.1 \times 10^{19} \mathrm{a} \mathrm{cos}^{-2} \sec ^{-1}$.

bCoseraint nriginally stazed as $2 \times 10^{\text {th }} \mathrm{c} / \mathrm{cm}^{2}$ over plant lifetime.

Constraint originally stated as $1 \times 10^{\circ}$ rads over plate lifetine (40 -ears at 0.02 operational).

drads in conctere.

DOT 2-D calculation was performed on the reference radial shield configuration. The interpretation of these results should be conditioned by the fact that the radial shield design is currently undergoing revision, so that these results are primarily useful as input information for development of new radial shield designs. The high-energy flux constraint is met by every shield configuration considered. The therwal flux criterion is met by all designs except for the revised design without $B_{4} C$. The PCRV heating constraint is in question only for the alternate $p-\theta$ path for the reference design. The results for the damage to the tendon lubricant are not definitive since the response function used does not represent the dose to the sperific grease exployed, but they certainly do indicate an area for future investigation, especially for a revised radial shield design.

On the basis of these one-dimensional calculations, a series of calculations of the flux and heating rates was completed for a new revised model in which the thorfum oxide density in the radial blanket was increased by 117 and in which the radial cavity thickness was decreased by approximately $0.3 \mathrm{~m}(1 \mathrm{ft})$ by a reduction in the outer radial shield. The revised outer radial shield used for these 
calculations consisted of approximately 0.18 a of graphite followed by 0.18 a of boronated graphite ( $197 \mathrm{Ba}, \mathrm{C}$ by weight) and $50 \mathrm{~m}$ of type 304 stainless steel. Both one- and two-dinensional calculations vere performed by use of the $P_{3}$ 51-25 coupled cross section set, and the results obtained are compared with those obtained fron sinilar calculations for the initial or reference codel in Table 4.10. As part of this overall calculational effort a he! iun-worth calculation was ade for the core

Tabie 4.10. Comparison of Currently Recolmended

Haxim Radiation Levels with Calculated

Values for the Initial and a Revised Model of the GCFR Radial Shield

\begin{tabular}{|c|c|c|c|c|c|c|}
\hline \multirow{2}{*}{$\begin{array}{l}\text { Calcu- } \\
\text { lation }\end{array}$} & \multirow{2}{*}{$\begin{array}{l}\text { Shield } \\
\text { Hodel }\end{array}$} & \multirow{2}{*}{$\begin{array}{l}\text { Place of } \\
\text { Measurement }\end{array}$} & \multicolumn{2}{|c|}{$\begin{array}{l}\text { Fluxb at PCN Liner, } \\
\text { a } \mathrm{Ce}^{-2} \sec ^{-1}\end{array}$} & \multirow{2}{*}{$\begin{array}{l}\text { Heating } \\
\text { In PCXN } \\
\left(W / D^{3}\right)\end{array}$} & \multirow{2}{*}{$\begin{array}{l}\text { Beating in } \\
\text { Tendon } \\
\text { Luricant } \\
\text { (rade in } \\
\text { grease) }\end{array}$} \\
\hline & & & $>1 \mathrm{HeV}$ & $<2.38 \mathrm{eV}$ & & \\
\hline \multicolumn{3}{|c|}{ Recomended constraint } & $2 \times 10^{9 c}$ & $1 \times 10^{5}$ & 1000 & $0.1^{d}$ \\
\hline $1-0$ & Initial & Core aldplane & $1.2 \times 10^{6}$ & $9.2 \times 10^{7}$ & 4.8 & $0.042^{e}$ \\
\hline 2-D & Inteial & Core aIdplane & $5.6 \times 10^{5}$ & $3.0 \times 10^{\circ}$ & 7.2 & 0.10 \\
\hline I-D & Revised & Corre atdplane & $1.6 \times 10^{\circ}$ & $3.5 \times 10^{\circ}$ & 350 & 2.4 \\
\hline 2-D & Revised & Core itplane & $1.2 \times 10^{\circ}$ & $3.9 \times 10^{\circ}$ & 200 & 1.6 \\
\hline 2-D & Intelal & $\begin{array}{l}\text { Lower ax:al } \\
\text { He chaunel }\end{array}$ & $2.4 \times 10^{7}$ & $3.7 \times 10^{19}$ & 700 & $5.5^{e}$ \\
\hline 2-D & Revised & & $9.9 \times 10^{7}$ & $4.6 \times 10^{10}$ & 900 & 7.1 \\
\hline 2-D & Intc1aI & $\begin{array}{l}\text { Wrap-around } \\
\text { region }\end{array}$ & $7.1 \times 10^{\prime}$ & $3.3 \times 10^{10}$ & 1000 & 7.7 \\
\hline 2-D & Revised & & $1.8 \times 10^{\circ}$ & $8.5 \times 10^{9}$ & 300 & 4.3 \\
\hline $2-D$ & Inteial & $\begin{array}{l}\text { Maxian above } \\
\text { wrap-around } \\
\text { region }\end{array}$ & $5.3 \times 10^{7}$ & $7.8 \times 10^{10}$ & 1800 & 0.3 \\
\hline $2-D$ & Revised & & $5.0 \times 10^{\circ}$ & $1.6 \times 10^{7}$ & 300 & 2.6 \\
\hline
\end{tabular}

arevised odel has about 0.3 a (1 ft) thinner outer shield (and correspondIngly reduced reactor cavity radius) consisting of about 0.18 a graphite followed by about 0.18 m boronated graphite (19 ve $2 \mathrm{M}, \mathrm{C}$ ) and by about 50 m type 304 stainiess steel.

blux levels normalized to a total flux of $7.1 \times 10^{19} \mathrm{n} \mathrm{cm}^{-2} \mathrm{sec}^{-1}$.

Conseraine originally staced as $2 \times 10^{10} \mathrm{n} / \mathrm{cm}^{2}$ over plant 11 fetiece.

'Conseraint originally stated as $1 \times 10^{\circ}$ rads over plant 11 fetince $(40$ years at $80 z$ operational).

erads in concrete.

For the intcial desigri chis maxiaus occurs thete the lower axial streamina path mets the PCRV liner. For the revised design it occurs at an axial position just below the inner shield. 
with a revised radial blanket kensity. The $k$ effective with helium present was 1.068. The $i$ effective without heliu present was 1.071 , giving a helfiw-worth $0: 70$ cents. In interpreting the table shown It should be noced that the constraints applied vere adapted fron the HTG progran and that constraints specifically applicable to the OCFR are gradually evolving. The constraint levels stated in this table are those that have been usei at ond during the past fiscal year, and should then be viewed as current indications of desired levels rather than as fixed naxim allowable radiation levels. Table 4.10 comares 1- and 2-D calculations for the initial and revised radial shield designs along the core ddplane. The revised design vas successful in meeting the current constrafints except for the dose to the tendon lubricant. As indicated previously, calculations for this constraint are not yet felt to be definitive because of the differences in the response functions (rads in silicon versus rads in tissue) and questions regarding the exact position of the tendon in the PCRV. Table 4.10 also comares 2-D results at positions of special interest in the lower axdal region for the initial and revised radial shield design. The results indicate that the revised design was reasonably successful in meeting current design criterla, especially those for high-energy flux levels and for heating in the PCRV. The theraal flux level criterion itself is currently in review, with a new critertion of $1 \times 10^{10}$ quite likely. This would render the thernal flux levels fairly acceptable with the exception of the lower axdal helium channel position, where the radial shield remains an area for further investigation, with a new constraint $(0.5$ versus $0.1 \mathrm{rads} / \mathrm{sec}$ ) also quite likely. In general, results for the revised design are encour 'ing in regard to $r$ ' -athp the reactor cavity radius.

A series of adjoint calculations for the two-dimensional revised design were inftiated. These will include calculations for the theras flux levels in the PCRV liner at the lower axial helfum channel and wraparound positions, PCRV gana heating at the lower axial hellum channel, and gama dose in the tendon lubricant at the lower axial hellum channel and wrap-around positions. These calculations will be applied in the 
cross section sensitivity studies to deternibe neutron transport nechanises and game production and transport mechanises in the current revised design and to Indicate the effects of potential design changes on these responses.

\subsection{DESIG AND PERPOCANICE OF THE RASIC DOD STRENIMU EXPERTILITS - C. E. Clif ford}

The basic rod streading experimental configurations vere designed, and experimental measuremeats vere planned and scheduled. Heasurements will be taken in single-cell and witiple-rod-array cylindrical geometries with sbout $50 \mathrm{z}$ rod fraction by volume. The rods to be wed in the experiments are about $1.1=(0.45 \mathrm{in.})$ in diameter and 1.37 . (54 in.) in overall length, with $76-(3 \mathrm{in.})$ of aiuninu at each end and an internediate 1.22 a (48 ln.) of 1.32 -enriched $\mathrm{OO}_{2}$.

The single-cell basic rod streaning experimental configurations have been fabricated and assembled. Current plans call for wasurenents of the flux everging from cells in which collinted and partially collimated bean sources are incident on vold cells and cells containing an Iron rod and an aluniaum-clad $\mathrm{VO}_{2}$ rod. The grid plates for use in the full-a:ray experimental configuration have been fabricated. They will support 859 rods in a triangular-pitch array that is approxiately 502 void. The plates will fit inside a 0.459-0-dian by 1.416-0-long (18 1/16- by 55 3/4-in.) pipe. Both the single-cell and the full-array configurations are enclosed in water-filled aluninum tanks.

A thin streaning experinent utilizes the new broad bean source from the Tower Shielding Reactor, which is estimated to have 200 tines the intensity of the sall bean. A spectral modifier has been incorporated into the experinental configuration to give a source spectrum wore typical of the leakage spectru from the GCFR core. Heasurements have been completed on the neutron transport through the $0.10-1\left(4-n_{\text {. }}\right.$ ) steel and 25-m (1-in.) boral spectru wodffier ut1lizing the 0.076-, 0.15-, and 0.25-a (3-, 6-, and 10-1r.) Bonner balls. * The water tank

\footnotetext{
* Bonner balls are neutron detectors embedded in polyethylene spheres. The size of the sphere governs the spectral response of the detector.
} 
for the single-cell experiment was delivered and placed in position. Preanalysis of the experiment shoved that the configuration needed to be edified to Inprove the siall collimtor geometry. Heasurements were taken of the foreground and background with the hole expty and also with the iron rod in place in the hole. The direct bean with no rod in the hole was only a 10 tines background. With the iron in position, the readings from the hole were well below background. These unfavorable conditions resulted in decision to proceed to the large collfator conf Iguration of the single-cell experinent.

During the woth of June, work was comleted on the single-cell pin streafing experiment. These masurements were lifited to the large collimator because of the relatively high level of background that was observed with this experinental configuration. Heasurements were taken with the 0.076-, 0.15-, ana 0.25- (3-, 6-, and 10-in.) Bonner balls for the case with no central rod in the single-cell configuration, the case with the steel rod present, the case with the uraniun rod present, and the case with the entire configuration filled with water. Host of these measurements ware repeated five or wre times, and the counting rate varied from 10 to 152 depending on the exact orientation of the central rods. The 0.46-a-dian (18-in.) full-array configuration (contalning 859 rods) is being installed at the present tin. It is anticipated that measurements on the full array configuration will be conpleted during July.

\subsection{PREAMALYSIS OF THE GCFR STREAMIMG EXPERIMLIT - c. 0. Slater} An initial calculation of an iron-rod "cell," consisting of an iron rof surrounded by air, was wade with the Dor two-dinenstonal discrete ordinates transport code ${ }^{2}$ :o exarine the effects of streaning in a simulated GCPR fuel-element geometry. The 0.76-0-long (30-in.) cell consists of a 7.2-a-dian (0.285-1n.) Iron rod with a surrounding $2.57=\left(0.101-1 n_{\text {. }}\right)$ air-3treaning gap, which simulates the triangular pitch between fuel rods with a fuel element. The results of this calculation vere to be compared with those for a homgeneous tron-air cell of sintlar dimensions as an initial step in designing a basic rod streantng experiment. 
Calculations for the prelininary version of the basic rod streaning experiment continued. A comparison of heterogeneous vs homgeneous DOT (2-D) calculations of an tron-rod-and-air "cell" indicated streaning that ay be sufficient for experimeatal purposes. A seometrical nodel, sintlar to a CCFR fuel element, composed of an iroo-rod lattice in air was set up for morSE ${ }^{\text {to }}$ Monte Carlo calculations to compare with the results of the DOT cell case.

Additional calculations were initiated to deternine the effects of varying the size and composition of the experimental configuration and the angular distribution of the experinental source. Using a 0.19(7.5-in.) unreflected radius for a homogeneous iroa and air configuration gave one sixth the cransaited flux obtained from a reflected case (equivalent to a one-dimensional infinite source calculation). Increasing the unreflected radius to 0.38 . (15 in.) gave one half the results of the reflected sase. A one-dinensional ANISK calculation of a depleted $\mathrm{UO}_{2}$-air experimental configuration gave one fourth the transinted flux for the iron-ait case. This was an indication that streaning through a configuration of $\mathrm{UO}_{2}$ rods should be more significant than strealiag through an iton rod configuration. Varying the angular distribution of the source shows that the wost forward-peaked portion of the source contributes $16 \%$ of the transatted flux although compising only 22 of the total source neutrons.

Results obtained up to this point indicated potentially large effects for forward-peaked source particles and for $\mathrm{NO}_{2}$ rods. The need for a heterogeneous versus homogeneous experimental comarison, presurably for tron rods parallel to the bean compared with iton plates perperdicular to the bean was also quite evident.

Analysis began on possible single-cell experimental configurations for a partially and a severely collimated bean source incident on void, Iron rod, and aluinum-clad $\mathrm{VO}_{2}$ rod cells. The adequacy of techniques available to calculate uncollided flux energing fron the single-cell configuration was investigated. An analytic solution was obcained for the problea and used as a standard for comparison. A morse Monte Carlo calculation came within 12 of the uncollided flux energing fron the cell 
frow a cource within a rod, but Dor discrete-ordiantes calculations, even rich highly blased quadrature sets, were not satisfactory. Brar ever, wea the Grivucl (bous a the "Great Decle") code, 13 which was writcen for we uith Dor to give a first collision soorce, was wed in che adjoint oode, agreeneat vas excelleat. It should be noted that this calculation represents a severe teat, since all the flur lies within a andar cosine of 0.999 to 1.0, and wot is usthin 0.999999 to 1.0. When calcalat fose were ande on a vold acollimed cell, Dot

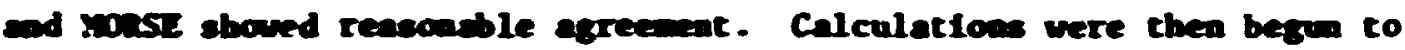
deternine the flux energing fron the face of the cell configuration, collinated and uncollimet, with rods present. The energing flux was to be calculated for specific agular orientations, and compared with the flux energas fron the veter-filled tank surromding the cell. The results of these calculations and comparisons is presented on the following self-coacalined report.

\subsubsection{Preanalyeis of the Storle-Cell streeting Experinents}

The preanalysis of the GCTh simple-cell streading experineats vas cartied out with DOT/FALSTF' ${ }^{15}$ ad checked in several instances with mase. The specification for the experinents are given in Sect. 4.2 and are not detalled here. Bowever, the experinental setup is shou in F18. 4.3.

The calculations were carried out with a cen-group enerts structure and were inteaded to show qualitatively wat soe should expect in the was of experimental censurements. They should give an indication of wich experinents can be carried out with litele difficulty and wich oves ay be carried out with a slicht codification of the experinental setup.

Seven cases were exalined: (1) en expty cell without source col1iat 10n, (2) an expy cell with source collination, (3) an Iros pin in the cell without collimazios, (4) an Iron pin in the cell with collineloo, (5) a $00_{2}$ pin in the cell wichout collination, (6) a $\mathrm{OO}_{2}$ pin in the cell with collinetion, and (7) the tank and sll chamels filled witl water. The later case when conpered with the other cases gives the excess transalssion provided by each of the other cases. 


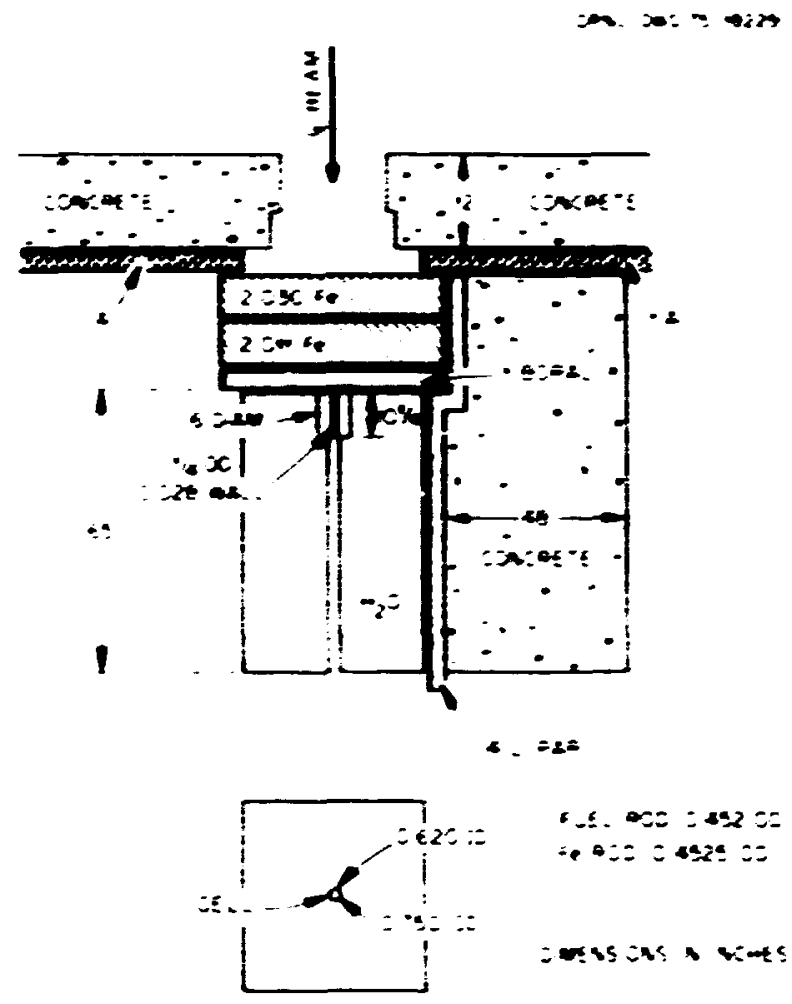

Fig. 4.3. Experimental Setup for the ccri single-cell streming Experinent. To convert dinenstons to allimeters, eultiply by 25.4 .

\subsubsection{Results}

Table 4.11 gives the relative leakages from the syster subdivided into the tank and cell leakages. In addition, the cell leakage is subdivided into the annulus and pin leakages. For cases 1, 2, and 7 the pin and annulus leakages are the leakages over the regions defined by the Iron or $\mathrm{UO}_{2}$ pia. Table 4.11 also gives the ratio of the cell leakage to the tank leakage for three energy ranges as well as for all energies. It is noted that with sufficient poisoning of the water In the taak, the leakage above $122.8 \mathrm{keV}$ donfnates for cases $1,2,3$, and 5. For these cases, the leakage above $122.8 \mathrm{keV}$ from the cell is at least 8 times that from the tank. The leakages for cases 3 and 5 seen to be attributable to direct streading from the source through the anaular gap sbout the pin, since the leakages are about the same in both cases. The fissions in the $\mathrm{UO}_{2}$ did not apprectably increase the cell leakage above that of the Iron pin in cace 3. A greater effect 
Table 4.11. Neutron Leakages from the Experineatal Assenbly

\begin{tabular}{|c|c|c|c|c|c|c|}
\hline $\operatorname{lam}_{10 x}$ & sontese & $i$ & $\infty$ & Pin & Cel: & Citit \\
\hline \multicolumn{7}{|c|}{ 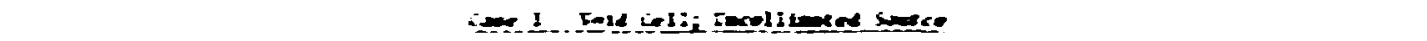 } \\
\hline$:::$ S het & $\therefore \cos 3 \cdot: 0^{-}$ & $1.31 \cdot 13^{-}$ & $\bullet: \because \cdot 10^{-}$ & $1.120-10^{-0}$ & $\therefore-2000^{\circ}$ & 253 \\
\hline 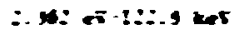 & $5.45 \cdot \mathrm{se}^{-}$ & $\therefore .606 \cdot 50^{-}$ & $0.0: 3 \cdot 10^{--}$ & $2 . \infty 1 \cdot 10^{-}$ & $\therefore \sin \cdot 20^{-0}$ & ä.•• \\
\hline$\therefore \cos$ & $a .0 \div::^{-}$ & $3.000 .90^{-}$ & $: 100 \cdot: 0^{-\infty}$ & $\therefore \infty: \cdot 19$ & $0 . \infty-10^{-0}$ & e.15 \\
\hline$a: 28 e$ & $4 .: 2 \cdot: 5$ & $0.0: \div \cdot 3$ & $1.555 \cdot 16^{-}$ & $\therefore: 13 \cdot 10^{+}$ & $\cdot 30:-30^{-}$ & $0.5 \times$ \\
\hline \multicolumn{7}{|c|}{ 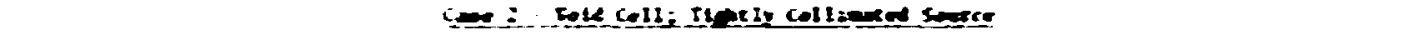 } \\
\hline ::-: nere & $\therefore: x-:-$ & $\therefore 20: 10^{--}$ & $5.535 \cdot 10^{-}$ & $2-3: Z \cdot 10^{-0}$ & $1.026 \cdot 10^{-0}$ & in \\
\hline$\therefore 30:$ at-1:2., & $1.356 \cdot 20^{-}$ & $1.200 \cdot 10^{-0}$ & $\cdot .050 \cdot 10^{-6}$ & $9.931 \cdot 10^{-}$ & $\therefore 140 \cdot 20^{-0}$ & $\therefore$ \\
\hline$\therefore x+5$ & $\therefore \infty ; 10^{-}$ & $1 .+1 \cdot 10^{+}$ & $\therefore 4 \times \cdot 10^{-0}$ & $\therefore-13 \cdot \omega^{\circ}$ & $3.010 \cdot 10^{\circ}$ & 0.035 \\
\hline atśre & $\therefore: \infty \cdot: \mathrm{o}^{-}$ & $1.2:=\cdot a^{-1}$ & $3.154 \cdot 29$ & $3.823 \cdot 19^{-0}$ & $\therefore-\mathbf{a n} \cdot \mathbf{2 5}$ & 9.ten \\
\hline \multicolumn{7}{|c|}{ 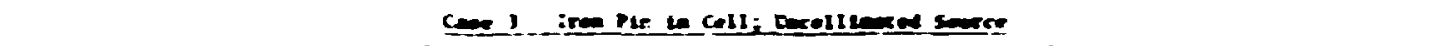 } \\
\hline ::2.:1 int & $.270 \cdot 10^{-0}$ & t.ess $\cdot 10^{-0}$ & $\bullet .61 \cdot \omega^{-}$ & $1.20: 10^{\circ}$ & $\bullet .56 \cdot 10^{-}$ & •.њ \\
\hline$\therefore$ so: ef i:2ss not & $\cdot 350 \cdot 10^{-*}$ & $3.3:=10^{-0}$ & S.i4a $\cdot 10^{-0}$ & $2-20 \cdot 10^{-0}$ & $3.0 \pi \cdot n^{-0}$ & I.:: \\
\hline$\therefore \mathbf{x : c}$ & $\therefore .036 \cdot 10^{-}$ & $1.028 \cdot 10^{\circ}$ & $\left(3 .-83 \cdot 10^{-}\right.$ & $3.1 \mathrm{~m} \cdot 1 \mathrm{e}^{-0}$ & $\bullet .20 \cdot 10^{-\bullet}$ & $0 . \infty$ \\
\hline eacire & $1.126 \cdot 10^{\circ}$ & $1.00 \cdot 10^{-}$ & $\therefore \mathbf{s} ; \cdot 10^{\circ}$ & $\therefore=10 \cdot$ & $\therefore$ :en: $=10^{-}$ & $0.0: 3$ \\
\hline \multicolumn{7}{|c|}{ 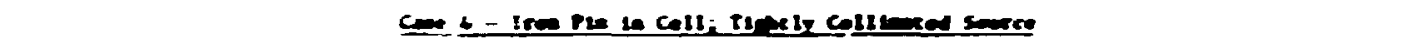 } \\
\hline 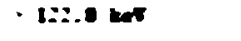 & $6.900 \cdot 10^{\circ}$ &.$+\pi \cdot \omega^{-1:}$ & $6.027 \cdot 10^{-1}$ & $1.00 \cdot 10^{-:}$ & $6.120 \cdot w^{-2}$ & B. is \\
\hline $201020-122.5$ tent & $\therefore \operatorname{ses} \cdot 10^{\circ}$ & $6 \cos \cdot \omega^{2}:=$ & 1.31: $\cdot \boldsymbol{w}^{\circ}$ & $2.30 \cdot 10 \cdot$ & $1 . i n \cdot \omega^{*}$ & 2.6: \\
\hline$\therefore \mathrm{wax}$ & $1 . \cos \cdot 10^{-4}$ & $0.333 \cdot 10^{-0}$ & $: .6: 3 \cdot 150$ & $6.26 \% \cdot 10^{-}$ & $1.111 \cdot 20^{\circ}$ & 0.021 \\
\hline exesto & 1.312: $\cdot 10^{-1}$ & $9.35 \cdot 100^{\circ}$ & $1 .: 12 \cdot 10^{\circ}$ & $\omega \cdot \boldsymbol{\omega}^{*}$ & $1-7=10^{-}$ & 0.081 \\
\hline \multicolumn{7}{|c|}{ 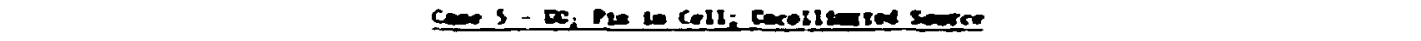 } \\
\hline - 12i.e bet & $\therefore 200 \cdot 10^{\circ}$ & $0.203 \cdot \omega^{-0}$ & $\bullet .519 \cdot \omega^{-}$ & $2.20 \cdot 10^{\circ}$ & $\bullet . ; 0 \cdot 10^{\circ}$ & 0.16 \\
\hline $2.392-122.0 \mathrm{~km}$ & $1.614 \cdot 10^{\circ}$ & b.im $\cdot \omega^{\circ}$ & $6.06 \cdot 10^{-1}$ & $\therefore 60 \cdot 10^{-9}$ & $\therefore .811 \cdot 10^{-0}$ & (.1) \\
\hline$\therefore 300 \circ$ & $\therefore \mathbf{H} 3 \cdot 10^{-}$ & $\therefore \cos \cdot 10^{-0}$ & $6.3: 2 \cdot 10^{\circ}$ & $1.2 \% \cdot 1 \sigma^{*}$ & $0.40 \cdot 10^{-6}$ & 0.000 \\
\hline entire & $\therefore \infty 10^{\circ}$ & $2.20 \cdot 10^{-0}$ & $\therefore .60 \cdot 10^{-1}$ & $6.095 \cdot 10^{\circ}$ & $-45 \cdot 80^{-0}$ & 0.00 \\
\hline \multicolumn{7}{|c|}{ 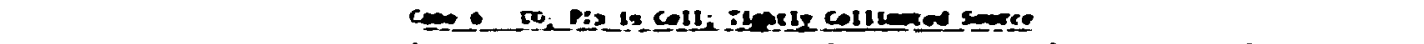 } \\
\hline $132.0 \mathrm{knt}$ & $1.40 \cdot 30^{-0}$ & $\therefore 902 \cdot 10^{-0}$ & $5.191 \cdot 10^{-0}$ & $\therefore 376 \cdot 10^{-18}$ & $3.460 \cdot 10^{\circ}$ & 1.e1 \\
\hline $2.302 * 122.9 \mathrm{~km}$ & $1.123 \cdot 80^{\circ}$ & $6.100 \cdot 10^{-0}$ & S.A:; $\cdot 100$ & S. $1: 20^{-} \cdot 3$ & $0.415 \cdot 16^{-}$ & 1.33 \\
\hline$\therefore: 100+$ & $\therefore 50: \cdot 10^{-4}$ & $2.191 \cdot \boldsymbol{w}^{-0}$ & $1.025 \cdot 10^{\circ}$ & $1.1 \% \cdot 10^{\circ}$ & $3.106-10^{-0}$ & 0.142 \\
\hline metire & $\therefore 521 \cdot 10^{-1}$ & $\therefore-16 \cdot \omega^{-*}$ & $3.00 \cdot 10^{\circ}$ & $1.10 \% \cdot 10^{-0}$ & $3.223 \cdot 10^{--}$ & - Hi \\
\hline \multicolumn{7}{|c|}{ 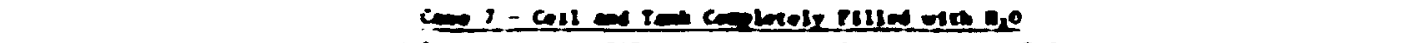 } \\
\hline$\cdot 121.4 \mathrm{ket}$ & $6.203 \cdot 10^{-.1}$ & $6.20:-10^{-1}$ & $1.2 \pi \cdot 10^{-:}$ & $1.455 \cdot 19^{-1}$ & $8.61 \cdot 10^{-1}$ & 0.000 \\
\hline$\therefore 100+122.8 \mathrm{ker}$ & $3.2 \mathrm{x} \cdot 19^{-.1}$ & $3.2 \pi \cdot 10^{-0:}:$ & $1.231 \cdot 10:=$ & $1.199 \cdot 10^{-} \cdot 1$ & $8946 \cdot 10^{-11}$ & e.ens \\
\hline $2.202 \oplus$ & $\therefore 163 \cdot 10^{-1}$ & $2.1+2 \cdot 10^{-1}$ & $1.20 \cdot 10^{-0}$ & t. ret $\cdot 10^{-6}$ & $3.50 \cdot 10^{-0}$ & 0.00 \\
\hline metire & $\therefore .14 \cdot 10^{-1}$ & $\therefore .263 \cdot 10^{-1}$ & $1.100 \cdot 10^{\circ}$ & $1: 00 \cdot 10^{-\circ}$ & $3.200=15^{-6}$ & -. $\cos$ \\
\hline
\end{tabular}


of the fissions is shown in the collineted source cases 4 and 6 . There the leakage from the $\mathrm{VO}_{2}$ case alnose docbles that for the iron case. The $\mathrm{wO}_{2}$ total cross sectiva is generally greater than the iron cotal cross section; heace, the larger leakage for the $\mathrm{HO}_{2}$ case is attributed to fissions rather than direct tramonission through the rod.

Table 4.12 gives relative fluxes at various detector positions beyond the experimental asseably. Table 4.13 gives the $\equiv>2.38 \mathrm{eb}$ flux for the sane locations. The detector positions are given by the paraneters $F$ and $t e$ show in Fig. 4.4. These values vere computed with FALSTF wing the scatcerifo sources generated by DOT. Values at selected locat fons conputed w.th ronsE are given in Table 6.14.

Table 4.12. Relative Seutron Flux at Selected Positions Beyond the Experimental Assembly - Calculated by DOT/FALSTF

\begin{tabular}{|c|c|c|c|c|c|}
\hline \multicolumn{2}{|c|}{ Position" } & \multicolumn{4}{|c|}{ Delatiw Flex } \\
\hline -(n) & $-(a)$ & $C=0$ & cears & 600 & case: \\
\hline$: 0.2$ & 0 & $\therefore 293 \cdot 10^{-}$ & 1,$1 ; 3 \cdot 10^{-4}$ & $1.500 \cdot 10^{-1}=$ & $\therefore 793 \cdot \mathrm{ic}^{-:}=$ \\
\hline$i n s_{2}:$ & 0.6 & $0.31: \cdot 10^{-0}$ & $3.34 \cdot 10^{-}$ & $\therefore: \infty 00 \cdot 0^{-\infty}$ & $: .812 \cdot 10^{-}:=$ \\
\hline 86.2 & in & $1.206 \cdot 10^{-2}$ & $1.023=19^{-6}$ & $1.003 \cdot 10^{-:}:$ & $2.25: \cdot 10^{-::}$ \\
\hline i6.: & 30 & $2.200 \cdot 16^{-:}:$ & $\$ .030 \cdot 10^{-::}$ & $9.600 \cdot 10^{-2:}$ & $2.69 \cdot 1 C^{-::}$ \\
\hline 152.6 & 0 & $1 . \sin \cdot 10^{-12}$ & $2 \cos \cdot 10^{-\circ}$ & $1.072 \cdot 10^{-1}$ & $0.625 \cdot 10^{-2}$ \\
\hline $15: .6$ & 0.36 & $6.36 ; \cdot 10^{-0}$ & $2 . \omega \cdot 10^{--}$ & $4.379 \cdot 10^{-1}$ & $0.700 \cdot 10^{-}:=$ \\
\hline 152.6 & ; & $9.912 \cdot 10^{-:}:$ & $3.140 \cdot 10^{-:}:=$ & $2.46 \cdot 10^{-}:=$ & $0 . \operatorname{sen} \cdot 16^{-:}$ \\
\hline 152.6 & 15 & •.4! : IC-': & $3.012 \cdot 10^{-::}$ & $3.278 \cdot 10^{-:}:$ & $0.163 \cdot 10^{-:}:$ \\
\hline 228.6 & 0 & $: .437 \cdot 10^{-2:}$ & $6.510 \cdot 10^{-9}$ & $3.616 \cdot 10^{-1}$ & $+.036 \cdot 10^{-1}:$ \\
\hline 220. & 0.23 & $2.050=10^{-0}$ & $1.012 \cdot 10^{-*}$ & $2.926 \cdot 10^{-1}$ & $6.002 \cdot 10^{-1:}$ \\
\hline 228. & 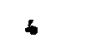 & $\$ .635 \cdot 10^{-:}:$ & $1.403 \cdot 10^{-1:}$ & $1.630 \cdot 10^{-i:}$ & $6.011 \cdot 10^{-:}:$ \\
\hline 226.8 & 10 & $6.530 \cdot 10^{-2:}$ & $1.460 \cdot 10^{-:}:$ & $1.309 \cdot 10^{-:}:=$ & $3.920 \cdot 10^{-5:}$ \\
\hline 263.46 & 0 & $9.205 \cdot 10^{--:}$ & $7.619 \cdot 10^{-0}$ & $6.006=10^{-1}$ & $3.505 \cdot 10^{-:}:=$ \\
\hline 263.46 & 0.21 & $2.46 \cdot 10^{\circ}$ & $1.723 \cdot 10^{-\circ}$ & $2 . \operatorname{cs} \cdot 10^{-0}$ & $3.609 \cdot 10^{-:}:$ \\
\hline 263.26 & 3 & 6.ces $\cdot 10^{-:}:$ & $1.307 \cdot 10^{-18}$ & $1.638=1.70:$ & $3.535 \cdot 10^{-:}:$ \\
\hline 263.16 & 10 & $6.001 \cdot 10^{-5:}$ & $1.29 \cdot 10^{-12}$ & $1 . \cos =10^{-:}:$ & 3. $142 \cdot 1 \sigma^{:}:$ \\
\hline 306. & 0 & $2.000 \cdot 10^{-1}$ & $1.296 \cdot 10^{-0}$ & $6.10^{-1}$ & $2.317 \cdot 10^{-:}:$ \\
\hline 506.0 & 0.17 & $1.005 \cdot 10^{-0}$ & $1.205 \cdot 10^{+}$ & $1.120 \cdot 10^{-0}$ & $2.351 \cdot 10^{-} \cdot:$ \\
\hline 306.0 & 2.5 & $2.41 \cdot 10^{-:}$ & e.551 $=10^{-::}$ & $9.652 \cdot 10^{-1}:=$ & $2.300 \cdot 10^{-:}:$ \\
\hline Dos.a & 1.5 & $\therefore .505 \cdot 10^{-\cdots}$ & $1.304 \cdot 10^{-:}:$ & $9.151 \cdot 10^{-:}:$ & $2.267 \cdot 10^{-18}$ \\
\hline 407.40 & 0 & $\therefore: n \cdot 10^{-1}$ & $3.001 \cdot 10^{-0}$ & $2.053=10^{-1}$ & $9.253 \cdot 10^{-12}$ \\
\hline wi.6 & 0.11 & $0.415=10^{-1}$ & $6.259=10^{-0}$ & $1.053=10^{-\circ}$ & $9.400 \cdot 10^{-i 2}$ \\
\hline 401.60 & i.s & $1.003 \cdot 10^{-:}:$ & $3.635 \cdot 10^{-::}$ & $3.056 \cdot 10^{-:}:$ & $9.191 \cdot 10^{-12}$ \\
\hline 601.60 & 6.5 & $1.05 s \cdot 10^{-::}$ & 3. $102 \cdot 10^{-\cdots:}$ & $3.700+10^{-:}:$ & $9.139=10^{-1}=$ \\
\hline
\end{tabular}


Table 4.13. Relative Reutron Flux Above $2.38 \mathrm{eV}$ at Selected Positions Beyond the Experinesial Assenbly - Caliulated by DOT/FALSTF

\begin{tabular}{|c|c|c|c|c|c|}
\hline \multicolumn{2}{|c|}{ Powiester } & \multicolumn{4}{|c|}{ Eelectere $\bar{c} \operatorname{lox}$} \\
\hline$-(\infty)$ & $=(4-6)$ & cones & coss 5 & come & $c=1$ \\
\hline 76.2 & $\mathbf{0}$ & $6.27 \cdot 10^{-: 3}$ & $1.22 \cdot 10^{-}:=$ & $9.13 \cdot 10^{-: 1}$ & b.* $\cdot 10^{-: \cdot}$ \\
\hline 76.2 & 0.66 & $2.96 \cdot 10^{-1}$ & $2.6 \cdot 10^{-\circ}$ & $5.09 \cdot 10^{-1}$ & $1.01 \cdot 10^{-1}$ \\
\hline 76.2 & 10 & $6.0 \cdot: 0^{-0}=$ & $5.13 \cdot 10^{-: 2:}$ & $3.55 \cdot 10^{-:}:$ & $+.5 \cdot 10^{-2}=$ \\
\hline 76.2 & 30 & $6.6 \cdot 10^{-:-}$ & $4.5: \cdot 10^{-::}$ & $2.83 \cdot 10^{-: 1}$ & $6.1 \cdot 10^{-: 0}$ \\
\hline 152. & 0 & $5.05 \cdot 10^{-:} \cdot$ & $1.57 \cdot 10^{-::=}$ & $1.46 \cdot 10^{--:}$ & $1.41 \cdot 10^{-2}=$ \\
\hline 152.6 & d. 34 & $2.62 \cdot 10^{-1}$ & $2.5: \cdot 10^{-}$ & $3.70 \cdot 10^{-\circ}$ & $4.56 \cdot 10^{-: 0}$ \\
\hline 152.4 & 5 & $1.91 \cdot 10^{-2 \cdot}$ & $1.22 \cdot 10^{-i:}$ & $1.11 \cdot 1 \sigma^{11}$ & $1.59=10^{-0}$ \\
\hline 152.6 & 15 & $1.60 \cdot 10^{-2 t}$ & $1.52 \cdot 10^{-:: 2}$ & $9.67 \cdot 10^{-10}$ & $1.20 \cdot 10^{-5}=$ \\
\hline 228.6 & o & $5.70 \cdot 10^{-: 2}$ & $i .90 \cdot 10^{-1}$ & $: .63 \cdot 12::$ & $7.1=10^{-:}:$ \\
\hline 228.6 & 0.23 & $1.56 \cdot 10^{-6}$ & $1 . x \cdot i e^{-}$ & $\therefore 31 \cdot: 0^{-1}$ & $2.63=10^{-30}$ \\
\hline 228.6 & + & $9.6 \cdot 10^{-:}$ & $8.56 \cdot 10^{-\cdots}$ & $3.30=10^{-0}$ & $3.9=10^{-::}$ \\
\hline 228.6 & 10 & $0.4 \cdot 10^{-: 5}$ & $: .46 \cdot 10^{-: 1}$ & $4.77 \cdot 10^{-:}=$ & $\therefore .6 \cdot 10^{-13}$ \\
\hline 263.26 & 0 & $6 . \% \cdot 10^{-:}=$ & $2.12 \cdot 10^{-1}$ & $9.32 \cdot 10^{-:}:$ & $7 . c \cdot: 0^{-18}$ \\
\hline 243.26 & 0.21 & $3.62 \cdot 10^{-9}$ & $1 . \omega \cdot 10^{-:}$ & $\therefore 27 \cdot 10^{-}$ & $2.6 \cdot 10^{-2 \cdot}$ \\
\hline 263.16 & 3 & $0.2=10^{-:}:$ & $7.29 \cdot 10^{-21}$ & $4.6 \cdot 10^{-: 0}$ & $4.9 \cdot 10^{-: S}$ \\
\hline 263.86 & 7.5 & $: .6 \cdot 10^{-::}$ & $6.510^{-1}:$ & $6.2 \cdot 10^{-:}$ & $6.5 \cdot 10^{-:}:$ \\
\hline 304.8 & 0 & $3.56 \cdot 10^{-::}$ & $6.50 \cdot 10^{-1}$ & $1.99 \cdot 10^{-: 1}$ & $4.7 \cdot 10^{-: 3}$ \\
\hline 304.0 & 0.15 & $1 . \cos =10^{-1}$ & $1.25 \cdot 10^{-\circ}$ & $1.50 \cdot 10^{-0}$ & $1.75 \cdot 10^{-:}$ \\
\hline 30.0 & 2.5 & $5.1 \cdot 10^{-: 8}$ & $5.11 \cdot 10^{-21}$ & $1.20=10^{-: 0}$ & $6.7=10^{-::}$ \\
\hline 306.8 & 7.5 & $5.0 \cdot 10^{-: 3}$ & $6.70 \cdot 10^{-2}: 1$ & $2.02 \cdot 10^{-: 0}$ & $4.7 \cdot 10^{-29}$ \\
\hline 407.60 & 0 & $1.01 \cdot 10^{-::}$ & $3.59=10^{-0}$ & $1.76=10^{-18}$ & $2.0 \cdot 10^{-2: 9}$ \\
\hline$\$ 1.60$ & 0.11 & $3.56=10^{-::=}$ & $6.41 \cdot 10^{-6}$ & s.26 $\cdot 10^{-: 1}$ & $9.0 \cdot 10^{-19}$ \\
\hline 407.60 & 1.5 & $2.1=10^{-23}$ & $2.3 \cdot 10^{-11}$ & $1.6 \cdot 10^{-10}$ & $1.9=10^{-i 9}$ \\
\hline 407.6 & 6.5 & $2.2 \cdot 10^{-: 3}$ & $1.0 \cdot 10^{-: 1}$ & $1.2 \cdot 10^{-10}$ & $1.9 \cdot 10^{-: 3}$ \\
\hline
\end{tabular}

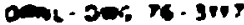

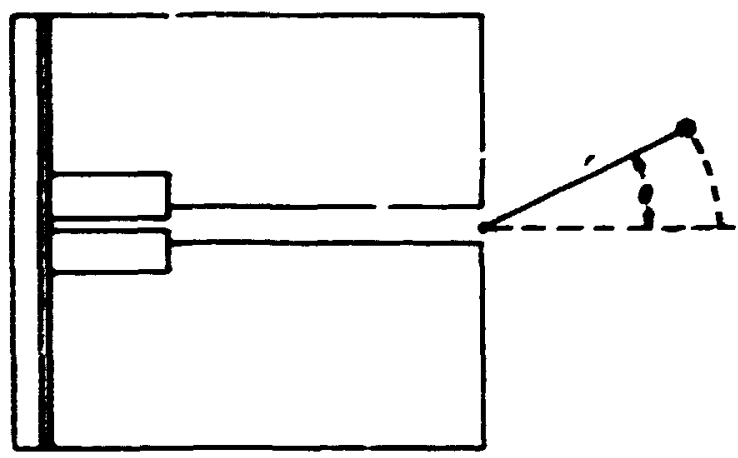

P18. 4.4. Diagra of Cosistent-Elevation Detecto: Traverse Shoulag the Arc Radius $(r)$ and the Angle from the Axis $(\theta)$. 
Table 4.14. Relative Neutron Flux Vulues at Selected Positions Beyond the Experinental Assembly - Calculated by mRSE

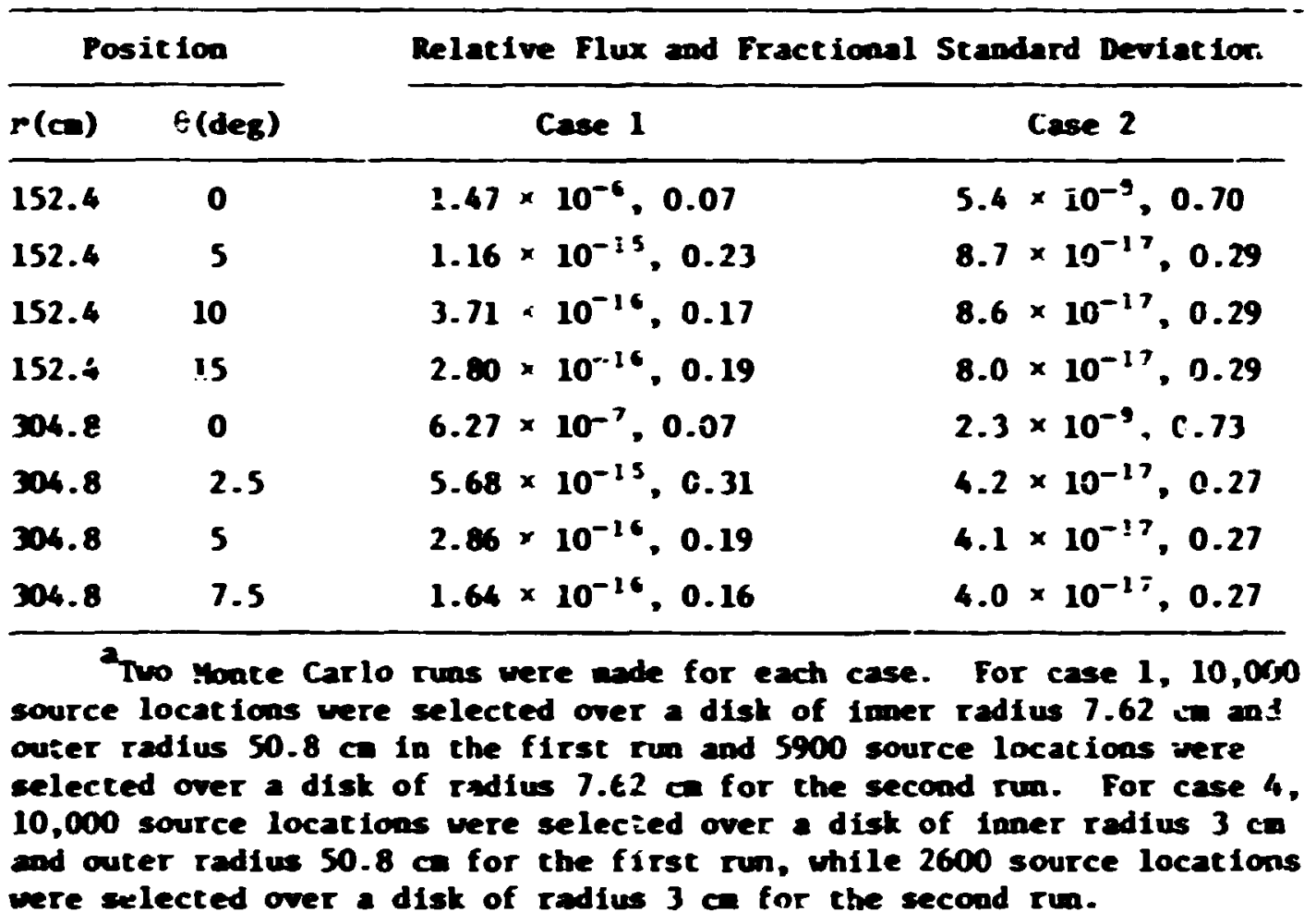

Table 4.12 shows that the total fluxes for cases 4 and 6 are about equal to that for case 7 (background) when the detector is far outside che cell radius. The cotal flux for case 6 in some instances is below background because of lack of convergency of the thermal group ( $\Sigma<2.38 \mathrm{eV}$ ). Table 4.13 shours the flux above $2.38 \mathrm{eV}$ for case 6 to be at least six tizes background at all locations. Bowever, for case 4, the flux at several positions is still barely above background.

Fable 4.15 compres the Dot-calculated $E>2.38 \mathrm{eV}$ and $E<2.38 \mathrm{eV}$ fluxes at the ead of the cell for the seven cases. The radius cortespords to the adpoint of the gap between the pin and the cell wall. Mubers computed with rorse for cases 1 and 4 are given for comparison. The Dor results shou that the flux above $2.38 \mathrm{eV}$ for caces 1 to 6 is a: least four orders of angatude bove that for case 7 (tank, cell, ard collirator filled with water). Hence, either cell significantly id:rexses 
Table 4.15. Relative Flux at the End of a Cell at a Radius of $6.807=$

\begin{tabular}{llllll}
\hline Case & $\begin{array}{c}\text { Relative Flux Calculated } \\
\text { Uith Dot }\end{array}$ & & \multicolumn{2}{c}{$\begin{array}{c}\text { Relative Flux and Fractional Standard } \\
\text { Deviation Calculated with monsE }\end{array}$} \\
\cline { 2 - 3 } \cline { 5 - 6 } & $E<2.38 \mathrm{eV}$ & $E>2.38 \mathrm{eV}$ & & $E<2.38 \mathrm{eV}$ & $E>2.38 \mathrm{eV}$ \\
\hline 1 & $1.429 \times 10^{-6}$ & $1.038 \times 10^{-3}$ & $1.2 \times 10^{-7}, 0.601$ & $7.06 \times 10^{-6}, 0.059$ \\
2 & $2.999 \times 10^{-6}$ & $8.316 \times 10^{-7}$ & & \\
3 & $8.785 \times 10^{-8}$ & $7.744 \times 10^{-7}$ & & \\
4 & $2.261 \times 10^{-7}$ & $6.337 \times 10^{-9}$ & $1.6 \times 10^{-1}, 1.0$ & $2.51 \times 10^{-9}, 0.3$ \\
5 & $1.396 \times 10^{-7}$ & $7.955 \times 10^{-7}$ & & \\
6 & $3.110 \times 10^{-7}$ & $1.225 \times 10^{-8}$ & & \\
7 & $5.117 \times 10^{-9}$ & $5.010 \times 10^{-1}$ & & & \\
\hline
\end{tabular}

the transmission through the tank in the vicinity of the cell. The flux below $2.38 \mathrm{eV}$ shows a smaller deviation.

A comparison of the DOT $\subseteq 1$ ux above $2.38 \mathrm{eV}$ results with the MORSE results shows fairly good agreement for case 1 , the DOT results being about $477 \mathrm{higher}$ than the MORSE result. The agreewent in the thermal range is not very good, possibly because of insufficiently deep penetration of particles into the tank. There is even less penetration with the collimator, so an even greater discrepancy is noted between the DOT and MORSE results for case 4, even for the high-energy neutrons. In this case the DOT flux above $2.38 \mathrm{eV}$ is 2.5 times the MORSE value. The MORSE result is probably lower than the true flux because of an insufficient nuber of events occurring deep within the tank and in the vicjaity of the cell.

\subsubsection{Count Rates}

Table 4.16 gives the counting rates with the 0.15-m (6-in.) Bonner ball.s expected if only the neutrons le.king from the cell are counted. of course not all of these will be counted as the detector is moved away from the cell.

Table 4.17 gives approximate count rates fcr the $0.15-1\left(6-1 n^{-}\right)$ Bonner ball at several positions for cases 4 through 7 and for the 


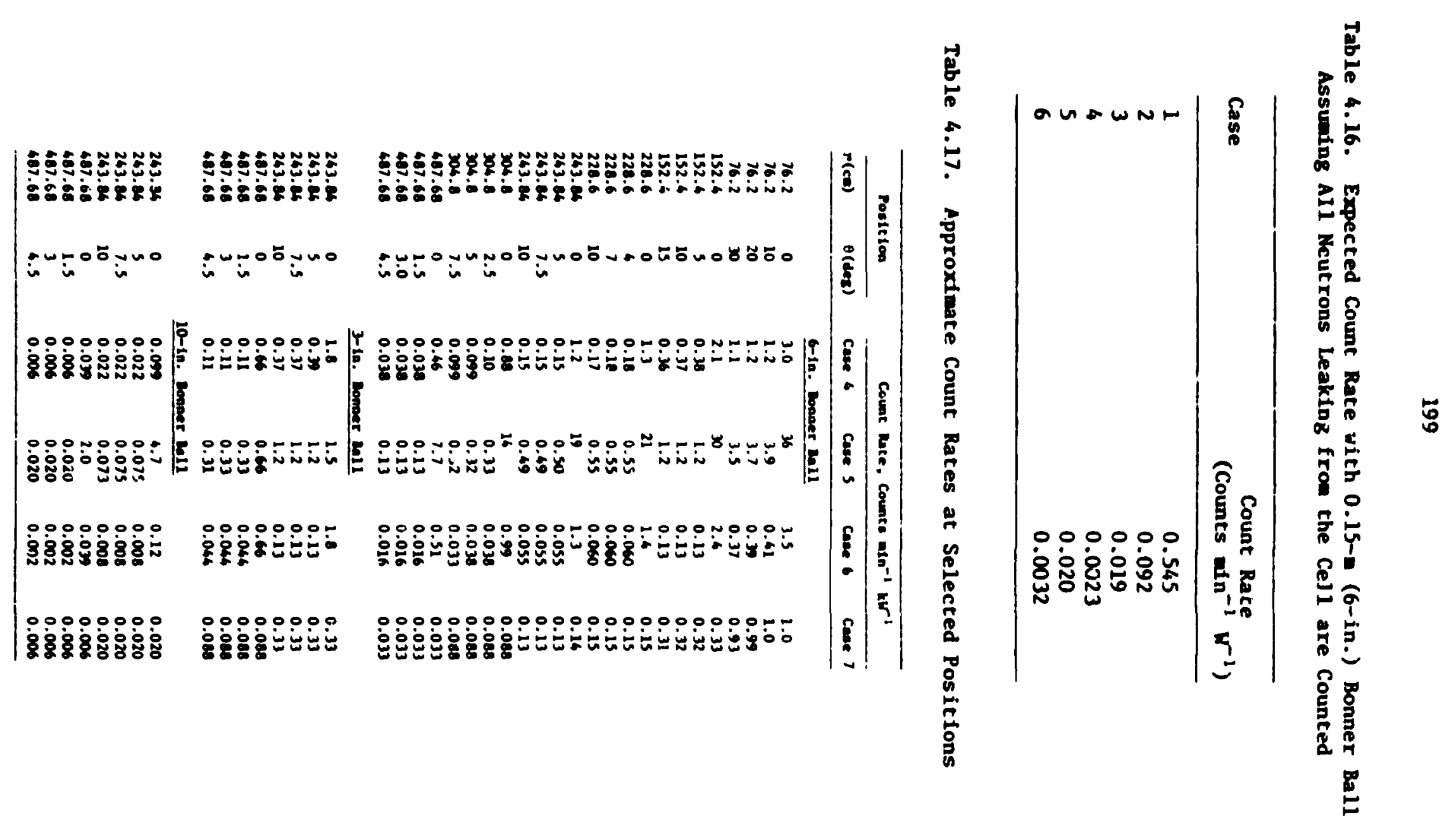


0.076- and 2.4- (3- and 10-in.) Bonner balls at a few positions. Again some of the case 6 count rates are lower than background because of insufficient convergence of the thermal flux.

\subsubsection{Source Normalization}

The source sirength for the wide bean of the TSF is expected to be about 200 times that for the 0.387-m-dian (15.25-1n.) beam. The old source strength was $4.5053 \times 10^{3} \mathrm{n} \mathrm{cm}^{-2} \sec ^{-1} \mathrm{w}^{-1}$ or $5.3091 \times 10^{\epsilon} \mathrm{n} \mathrm{sec}^{-1} \mathrm{w}^{-1}$. The wide bean source strength is thus $1.0618 \times 10^{3} \mathrm{n} \mathrm{sec}^{-1} \mathrm{w}^{-1}$ or $1.3097 \times 10^{5} \mathrm{n} \mathrm{cm}^{-2} \sec ^{-1} \mathrm{w}^{-}$distributed over a 0.10-m-dian (4-in.) disk. All results in Tables 4.12 through 4.15 should be wultiplied by the appropriate wide-bean factor and the reactor power in watts to obtain absolute values.

\subsubsection{Conclusions}

In all cases it was seen that the $E>2.38 \mathrm{eV}$ leakage from the cell was greater than that from the tank. And in all cases the $E<2.38 \mathrm{eV}$ leakage from the system was greater than the $E>2.38$ leakage, with the tank being the main source of the $E<2.38 \mathrm{eV}$ leakage. The addition of poison in the vacer in the tank would significantly reduce the thermal leakage and thus make leakage from the cell greater than that from the tank.

It was also noted that the $E>2.38 \mathrm{eV}$ leakage from the cell for case 5 was virtually unchanged from that for case 3 . That is to say, only a small increase in leakage occurred when the fron pin was replaced by the $\mathrm{UO}_{2}$ pin. Perhaps this is due mainly to the fact that with the partial collimator, most of the leakage can be attributed to uncollided neutrons. On the other hand the $E<2.38 \mathrm{eV}$ leakage from the tank and the system itself was more than doubled. This could be due to the fast neutrons generated in the $\mathrm{UO}_{2} \mathrm{pin}$ being thermalized near the end of the tank and emerging as thermals. If the increase in the leakage can be attributed to fissions in the $\mathrm{UO}_{2} \mathrm{pin}$, the results show that in the $E>123 \mathrm{keV}$ range the additional leakage is split equally between the cell and tank. In the intermediate energy range, the additional leakage 
fron the tank is $\mathbf{Z} .5$ tices that from the cell. This wy indicace a significant coupling ano cells in a rod array, in that significant numer of neutrons produced in one cell could then be expected to strean out through surreunding cells.

\subsubsection{Preanalysis of the Full-Array Streangs Experinent}

Other efforts were directed toward the preanalysis of the GCFR fullarray streaming experiment, including the mokup of the geometry of the full-rod-array experiment for a MORSE calculation. Because of reflective boundary requirements, this is requiring the designation of an exceptiorally large nuber of bodies. The setup for the problen is therefore quite lengthy and complex, and it is anticipated that the calculation will require a large core storage area and a long running time. DOT calculations of the honogeneous full-array experimental configuration, both foxward and adjoint, will therefore be made to assist in the MORSE Hoite Carlo calculation of the heterogeneous full array. Adjoint DOT calculations have been made with a 0.15-m (6-in.) Bonner ball response as the source at two locations beyond the tank. In these calculations the $\mathrm{UO}_{2}$ rods were howogenized radially within the full array configuration, and work has continued on the MORSE full-array configuration. The geometry package has been checked out for the MORSE run, and the cross sections have been prepared and checked out with short runs with the current source representation. Next the forward and adjuint rod calculations will be applied to ald in blasing the MOKSE fuli-array heterogeneous calculation, and checkout of the calctiation will continue, leading towards performing the full-array calculation when a suitable source representation is avallable.

The major effort in June was directed toward obtaining a reasonably representative TSR-II source calculation for use in analyzing GCFR pin and full-array streaming experiments. This was necessary because of the change from the small beam to the new broad beam configuration for the source. The problem involved converting angular fluxes on the boundary of the TSR-II reactcr to a source that could be used in DOT. Three alternatives were to: (1) convert the angular fluxes to an equivalent point source 
at the spherical center and then generate a first collision source for DOT, (2) use the unaltered angular fluxes to generate a first collision source for DOT, or (3) convert the angular flures to a disk source. The latter approach was taken. The source calculation was carried through the spectru wodifier. A preliainary calculation shous a 0.15-a (6-in.) Bonner ball measurement to be about $40-502$ higher then the calculated result using the current source presentation.

\subsection{REFERENCES}

1. General Atonic Company, 300-wN(e) Gas-Cooied Fast Breeder Reactor Demonstration Picont, GA-A-13045 (July 15, 1975).

2. F. R. Mynatt et al., The DOT-III Two-Dimensional Discrete Ordinates Transport Code, ORNL-TH-4280 (1973).

3. D. E. Bartine, L. R. WHllias, J. V. Pace III, and F. R. Myate, "Prelininary Shielding Analysis of a Reftrence Design 300-Mu(e) Gas-Cooled Fast Breeder Reactor," Trans. Am. Mucl. Soc. 21: 525 (1975).

4. H. M. Greene and C. W. Craven, Jr., XSDRN: A Discrete Ordinates Spectral Averaging Code, ORML-TI-2500 (July 1969).

5. I. I. Bondarenko, ed., froup Constants for huclear Reactor CalcuLations, Consultants Bureau, New York, 1964.

6. D. R. Mathews et al., CGC-5, A Computer Progran for Calculating Neutron Spectra and Group Constants, GA-8871 (1971).

7. N. M. Greene, J. L. Lucius, L. M. Petrie, M. E. Pord III, J. E. White, and R. Q. Wright, ANPX: A Modular Code Sybtem for Generuting Coupled Multigroup Neutron-Gomma Libraries from ENDP/B, ORN-TH-3706 (1975;.

8. K. Way, ed., Fuclear Data Tables, 5, No. 3, 4, pp. 412-13 (1969).

9. B. A. Engholm, Radiation Flur and Reating Levels in the HTGP, GA-A-12201 (August 1972).

10. R. J. Cerbone, G. A. Ducat, M. T. Simad, Development Program Plan for GCPR Shielding, GA-A-13291 (1975).

11. W. W. Engle, Jr., "A Users Mapual for AHISH, A One-Dinensional Discrete Ordinates Transport Code with Anisotroplc Scattering," K-1693, Computing Technology Center, Union Carbide Corp. (1967). 
12. D. E. Bartine, F. R. Hyat, and E. M. Oblow, SHArLAiE, f Conputer Code Vtilizing ANISH Tronoport CaIculations for Cross-Section Sensitivity Analysis, Ond-Tt-3809 (1973).

13. M. Ragel, C. A. Rouse, A. Razani, and R. J. Cerbose, "Radial Shield Design Considerations for a $300 \mathrm{~m}(\mathrm{e})$ Gas-Cooled Fast Ireeder Reactor," Trams. An. Iucl. Soc. 21: 526 (1975).

14. E. A. Straker, P. X. Stevens, D. C. Irving, and V. R. Cain, The MORSE Code - A Multigroup Neutron and Ganma-Pay Monte Carlo Tronsport Code, Opul-4585 (1970).

15. GrTunicl calculate the uncollided flux and the first-collision source resulting fron a point source, which is used as input in the Dor code to calculate the flux within the shield. FalstF then calculates the flux at points outside the shield. This latter calculation favolves a volume integration in which the last-flight contribution of all sources (including scattering sources) is obtained. 


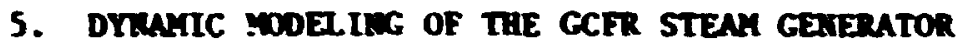

0. W. Burke

The final refinements to a dynanic wolel of the CCFR sten generator vere conpleted. The hybrid computer adel is a continuous space, discrete time wodel of the feeduater flow control valve, the stean generator, and the heliu circulator control valve. The variables used in the calculaFlons in this wodel are updated at 77 space points in the stean generator, anking it a very fibe-structured model. The profiles of the steam generator variables of interest were generated for design point, steadystate operation, and they were very nearly the same as those generated by $G A$ with its nodel. The save test transient was run usicg this codel, and $G A^{\prime} s$ overall systua codel and the results were in fair agreenent. The work was terwinated before obtaining s'gnificant results. 


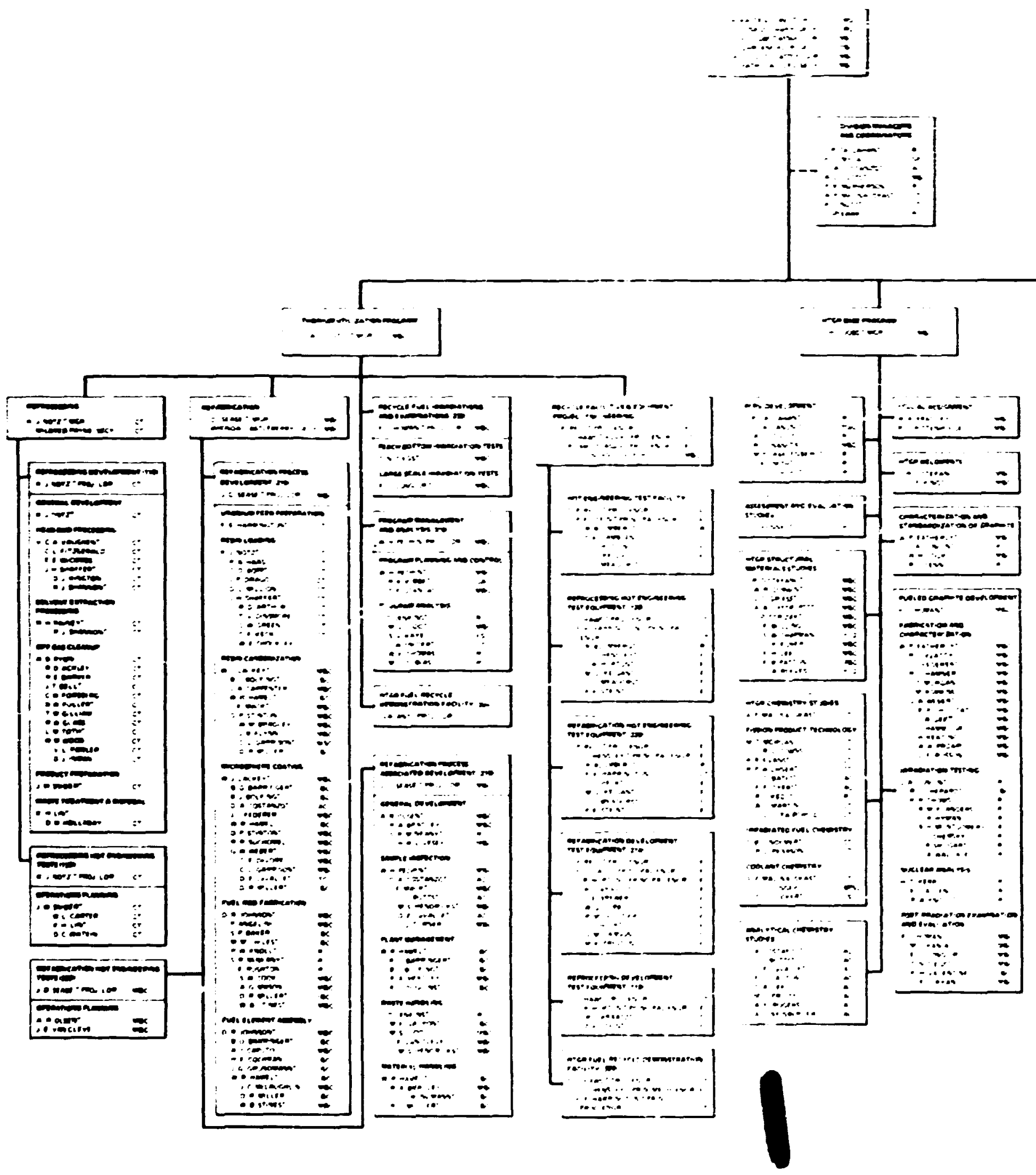




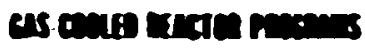

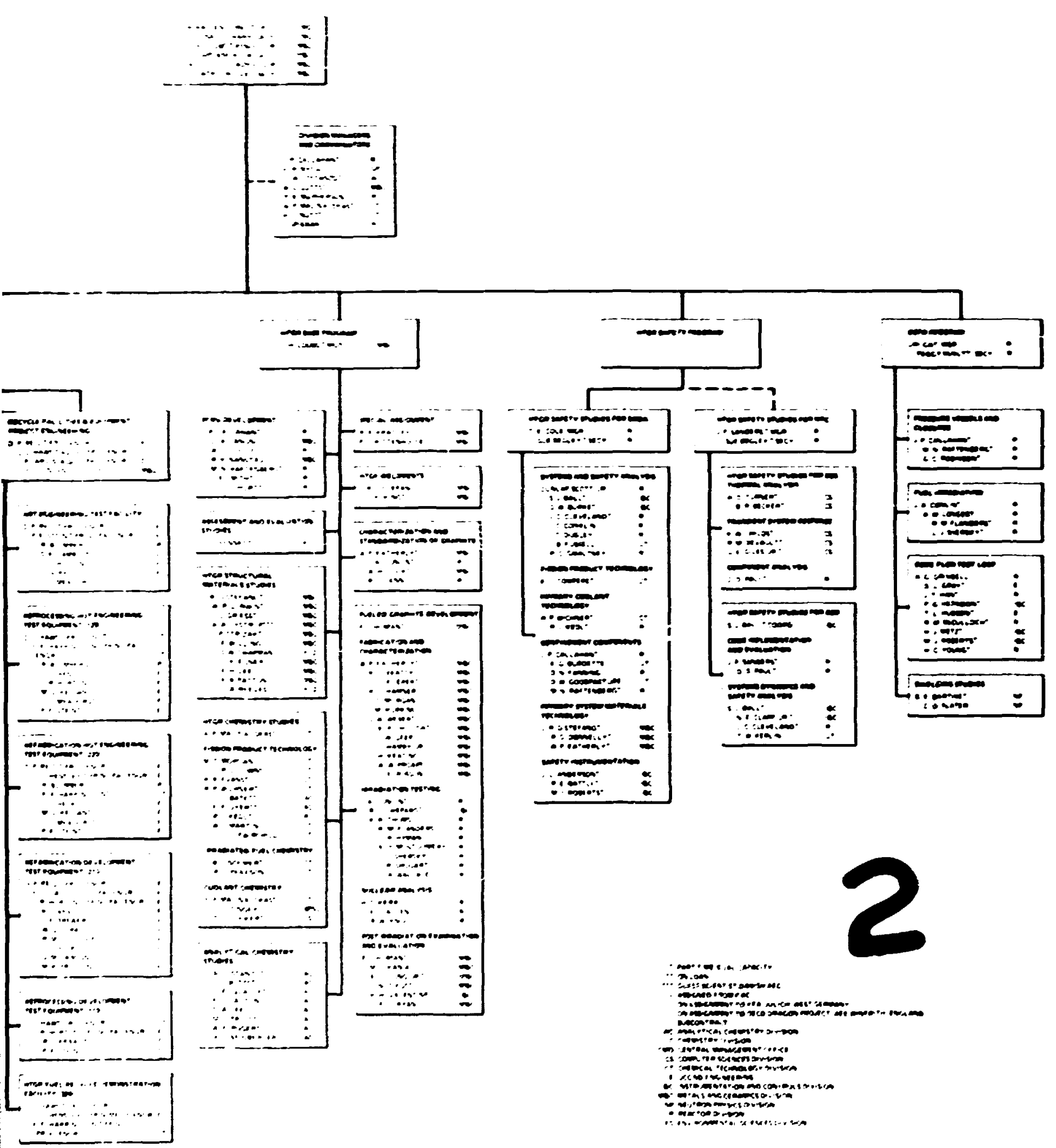

